\title{
A BIOENGENHARIA NO BRASIL, SÉCULO XX: ESTADO DA ARTE
}

Dissertação de Mestrado apresentada ao programa de Pós-Graduação Interunidades em Bioengenharia - Escola de Engenharia de São Carlos / Faculdade de Medicina de Ribeirão Preto/Instituto de Química de São Carlos da Universidade de São Paulo, como parte dos requisitos para obtenção do título de Mestre em Bioengenharia.

Orientador: Prof. Dr. João Manuel Domingos de Almeida Rollo

SÃO CARLOS

2004 
A Deus, pela benção da vida, pelo amparo e orientação nos momentos difíceis.

"A ciência sem a religião é manca, a religião sem a ciência é cega".

Einstein 


\section{DEDICATÓRIA}

A minha filha Tatiana Antonio pelo amor carinho e incentivo.

Ao meu pai Waldomiro Antonio (in memória) e a minha mãe Maria Aparecida por tudo o que fizeram e me ensinaram que a vida deve ser vivida com dignidade, e que muitas vezes renunciaram aos seus sonhos para que os meus fossem realizados.

Aos meus irmãos, Rita de Cassia, Angela Maria, Waldomiro Antonio Filho pelo amor e amizade que nos une.

Aos meus sobrinhos, Wellington Fernando, Wallison Luis, Emily Maria.

A minha avó, Maria Carmem Bargas Bergamasco (in memória) e meu avô Silvio Bergamasco, pelo carinho e apoio sempre.

Ao Marcos Antonio dos Santos e Cícero Aparecido Silva, pelo suporte na realização deste trabalho.

A todos os amigos da pós-graduação pelos bons momentos de convívio, que de uma forma ou outra me ajudaram.

Ao meu orientador Prof. Dr. João Manuel Domingos de Almeida Rollo, mais que um orientador, um amigo, pelo apoio nos momentos que mais precisei. 


\section{AGRADECIMENTOS}

A todos os professores, funcionários e colegas do Programa de Pós-Graduação Interunidades em Bioengenharia, que de alguma forma me ajudaram.

As empresas que me atenderam no decorrer da minha pesquisa de campo.

A minha admiração especial pelo engenheiro Tomaz Puga Leivas, que me auxiliou indicando o caminho a seguir.

Ao Dr. Manlio Mario Marco Napoli, por sua preciosa colaboração e atenção que dedicou a minha pessoa, ao carinho e auxilio na minha pesquisa.

Ao Dr. José Francisco Biscegli e Aron José Pazin de Andrade, do Instituto Dante Pazzanese de Cardiologia, por terem acreditado no meu trabalho.

A todos os colaboradores que detalharam informações preciosas, lembranças que o tempo marcou e amigos que juntos fizeram a bioengenharia acontecer no Brasil.

Aos colegas de disciplina e todas as pessoas que de alguma forma colaboraram para a realização deste trabalho.

Às secretárias Janete Ferreira Rodrigues dos Santos e Melaine Priscila Fidelix do Programa Interunidades em Bioengenharia, sempre muito atenciosas.

À secretária Maria Regina Ferreira da Costa, do Depto de Engenharia de Materiais, Aeronáutica e Automobilística - SMM, pela boa vontade sempre.

Para amiga Luzia S. Fernandes Costa, Departamento Ciência da Informação - DCI da Universidade Federal de São Carlos, pelo incentivo, apoio e amizade. 


\section{RESUMO}

ANTONIO, A. M. (2004) A Bioengenharia no Brasil, Século XX: Estado da Arte. Dissertação (Mestrado) - Escola de Engenharia de São Carlos/ Faculdade de Medicina de Ribeirão Preto/ Instituto de Química de São Carlos, Universidade de São Paulo, São Carlos, 2004.

Apresenta-se uma retrospectiva histórica do conhecimento e aplicação da engenharia biomédica/bioengenharia no Brasil; no período do século XX, enfocando a História da Arte brasileira com relação à engenharia biomédica/bioengenharia, evidenciando perspectivas de desenvolvimento deste interessante campo de conhecimento.

Por razões metodológicas e didáticas dividirão a engenharia biomédica/bioengenharia em áreas de aplicação: cardiologia, ortopedia, odontologia, oftalmologia, medicina regenerativa coadunando as áreas de ciências exatas e da terra onde, por exemplo, os conhecimentos das propriedades dos materiais utilizados, são evidenciados como composição química, estrutura, propriedades e aplicações, contextualmente definida como aplicação da engenharia biomédica/bioengenharia na medicina, de forma transitória ou permanente pelos diversos tecidos dos organismos dos seres vivos. Eles são utilizados como um todo ou parte de um biológico que trata, restaura ou substitui algum tecido, órgão ou função do corpo humano ou ainda como um material não viável utilizado em um dispositivo médico, com a intenção de interagir com o sistema biológico.

A definição de bioengenharia foi encarada nessa dissertação de forma a direcionar a pesquisa de campo em empresas e núcleos que desenvolvem biomateriais, entrevistas com pessoas que vivenciaram o desenvolvimento da bioengenharia no Brasil, preparando um compêndio da história da bioengenharia no Brasil, no século XX.

Palavras-Chave: Bioengenharia no Brasil, Ortopedia, Cardiologia, Odontologia, Oftalmologia, Medicina Regenerativa 


\begin{abstract}
Antonio, A. M. (2004). -The Brazilian's Bioengineering on XX Century: Art's State. Dissertation (Mastership) - Escola de Engenharia de São Carlos/ Faculdade de Medicina de Ribeirão Preto/ Instituto de Química de São Carlos, Universidade de São Paulo, São Carlos, 2004.
\end{abstract}

Show up a historical retrospective of knowledge and appliance of biomedic engineering in Brazil, on period of XX century, focus the History of Brazilian Art with relation of biomedic engineering, connecting perspective of development of this interesting knowledge filld.

For methodological and didactic reasons biomedic engineering was divide in areas of appliance cardiologic orthopedic, odontology, ophthalmology, regenerate medicine connecting areas of exact science and earth where, for example, the knowledge of property of material used, are evidence like chemistry composition, structure, properties and appliances contextualmente defined like appliance of biomedic engineering in medicine, on transitory or permanent form by several tissues of creature organisms. They are used as a whole or a part of a biological than treat, repair or replace some tissue, organ or function of human body or even like a material not possible to use in a medical gadget, with purpose of interragir with a biological system.

The definition of bioengineering was look at in that dissertation so that direction to research field in enterprises and centers that development biomaterials, interview with peoples that live the development of bioengineering in Brazil, make compêndio of Brazilian bioengineering history, on XX century.

Key Words: Bioengineering in Brazil, Orthoped, Cardiology, Odontology, Ophthalmology, Regenerate Medicine. 


\section{LISTA DE FIGURAS}

Figura 1 Implantação da Ferrovia no Brasil ............................................................ 16

Figura 2 Faculdade de Medicina da Bahia .......................................................... 23

Figura 3 Faculdade de Medicina de São Paulo ...................................................... 25

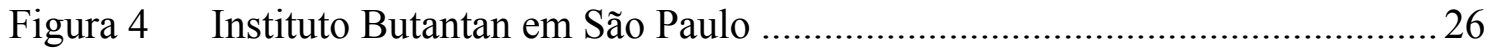

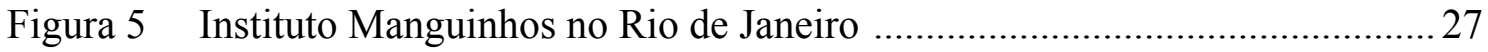

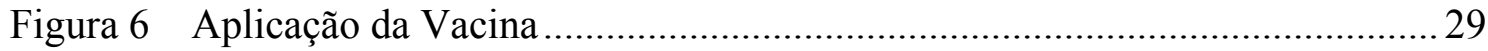

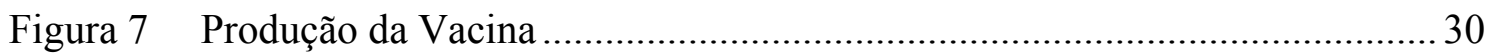

Figura 8 Instituto Bacteriológico Adolfo Lutz em São Paulo .................................... 34

Figura 9 Mapa do Brasil, evidenciando os estados que desenvolvem bioengenharia .45

Figura 10 Exemplos de biomateriais utilizados na substituição ou reparo de partes do

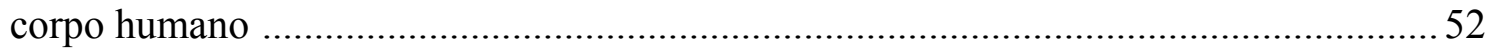

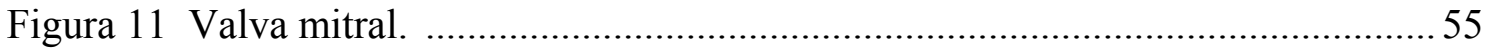

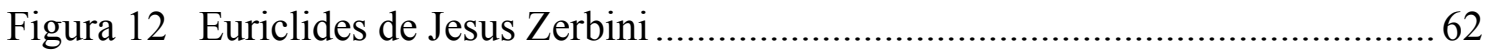

Figura 13 Análise Comparativa Anual do Número de Transplante - por Órgão de 1995 a 2002

Figura 14 Número de Transplantes Cardíacos por Estado no período de 01/01/2003 à

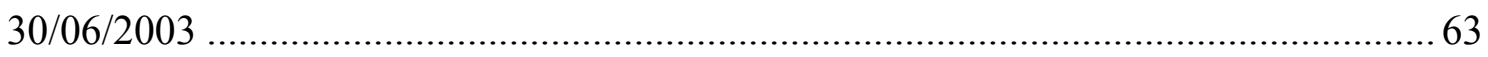

Figura 15 Valva Aortica em funcionamento (A) aberta (B) fechada............................ 66

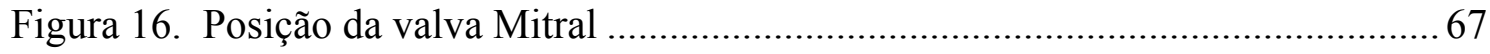

Figura 17. Valva Mitral em funcionamento (A) aberta (B) fechada...............................68

Figura 18. Pavilhão Fernandinho Simonsen em São Paulo ........................................... 74

Figura 19. Ossos humanos frescos retirados de um doador ....................................... 80

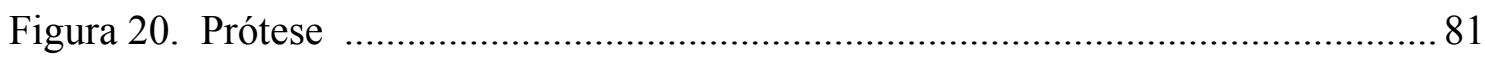

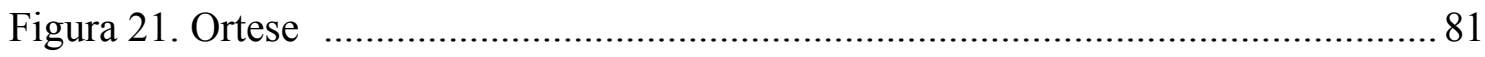

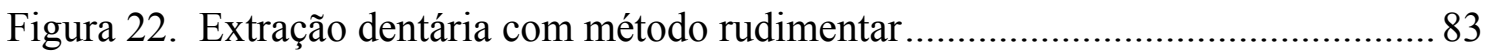

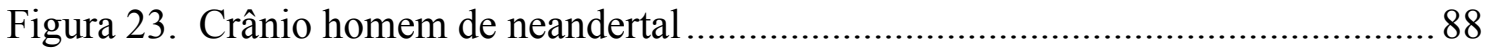

Figura 24. Prótese mandibular fixa-quatro incisivos humanos naturais e dois dentes talhados em marfim.

Figura 25. Dente artificial ou pôntico, deste fragmento de dentadura fixa etrusca se perdeu; ele substituía o incisivo superior central direito, e provavelmente tratava-se de um dente de boi preso por rebite a lamina de ouro. 
Figura 26. Dente canino duplamente preso com fio de ouro e dois incisivos direitos unidos entre si com fio de ouro enfiado através do incisivo central e atado ao incisivo lateral com uma volta. Uma ponte fixa que pertence ao Reino Antigo. ........................ 90 Figura 27. Dentes de um crânio da comunidade Maia, do século IX d.C. traz várias

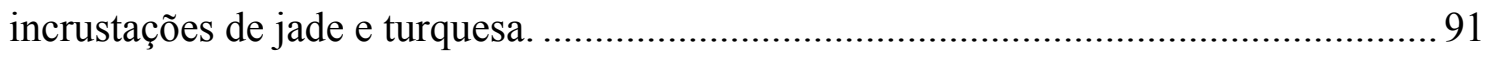

Figura 28. Dentadura completa confeccionada em madeira. …................................. 92

Figura 29. Molde confeccionado em madeira........................................................... 93

Figura 30. Ilustração por volta de 1910, Durif Bedel retratou o laboratório do seu

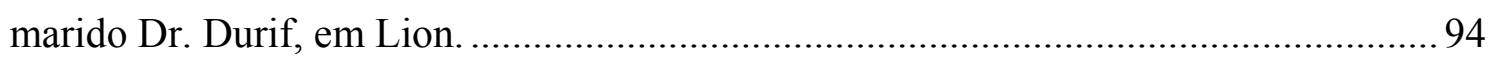

Figura 31. Implante Dentário para fixação ponte móvel e dentadura. .......................... 95

Figura 32. Aplicação da Medicina Regenerativa..................................................... 100 


\section{LISTA DE ABREVIATURAS}

$\begin{array}{ll}\text { CACEX } & \text { Carteira de Comércio Exterior. } \\ \text { CAPES } & \text { Coordenação de Aperfeiçoamento de Pessoal de Nível Superior } \\ \text { CNPq } & \text { Conselho Nacional de Desenvolvimento Científico e Tecnológico. } \\ \text { CEDHAL } & \text { Revista de História do Brasil } \\ \text { DOT } & \text { Departamento de Ortopedia e Traumatologia } \\ \text { EIAP } & \text { Cadernos da EIAP-Fundação Getulio Vargas- Escola Interamericana de Administração } \\ & \text { Pública- Rio de Janeiro. } \\ \text { FFCLH } & \text { Faculdade de Filosofia Ciências Letras Humanas } \\ \text { FMUSP } & \text { Faculdade de Medicina da Universidade de São Paulo } \\ \text { FUNCOR } & \text { Fundo de Aperfeiçoamento e Pesquisa em Cardiologia. } \\ \text { FUNBEC } & \text { Fundação Brasileira para o Desenvolvimento o Ensino de Ciências } \\ \text { HC } & \text { Hospital das Clínicas } \\ \text { HCSP } & \text { Hospital das Clínicas de São Paulo } \\ \text { HDL } & \text { Higt-Density Lipoprotein - Lipoproteína de Alta Densidade (remove o colesterol da }\end{array}$
corrente sangüínea).

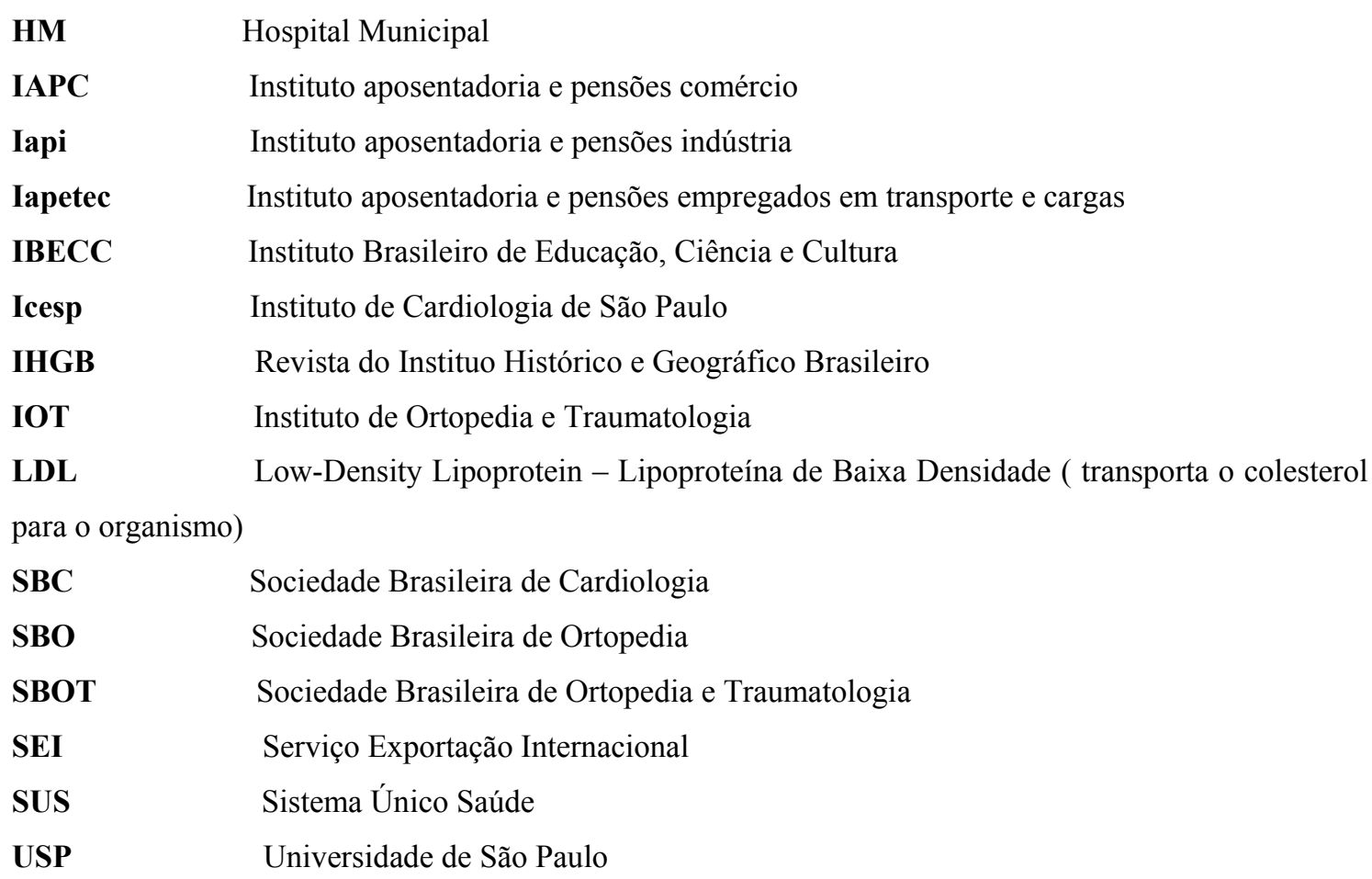




\section{LISTA DE TABELA}

Tabela 1 - Número de imigrantes no Brasil .................................................................... 17 


\section{SUMÁRIO}

RESUMO

ABSTRACT

LISTA DE FIGURAS

LISTA DE ABREVIATURAS

LISTA DE TABELAS

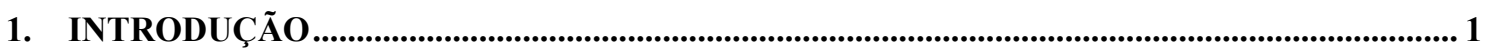

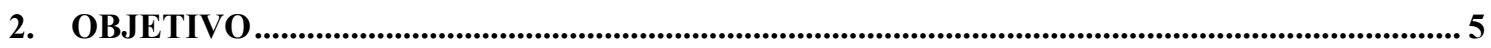

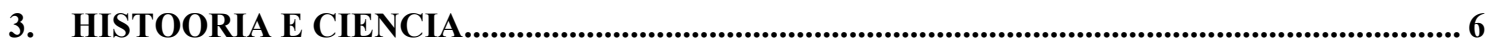

4. HISTORIA DO BRASIL E O SURGIMENTO DAS ESCOLAS DE MEDICINA....................... 14

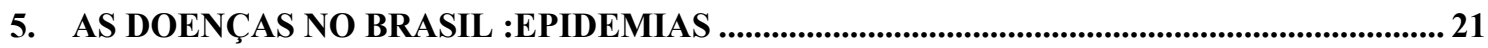

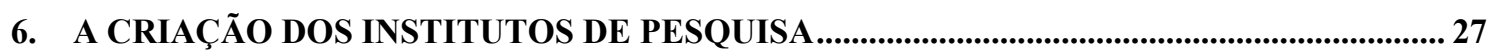

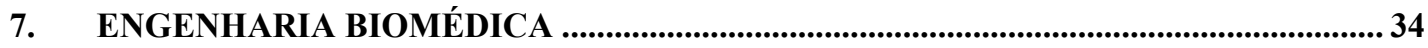

7.1. ENGENHARIA DE REABILITAÇÃO.......................................................................... 34

7.2. INFORMÁTICA MEDICA.................................................................................................. 35

7.3. ENGENHARIA CLINICA OU HOSPITALAR ........................................................................ 35

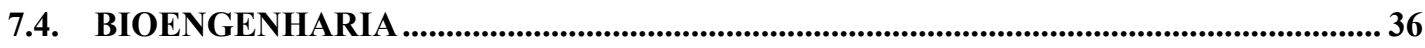

8. COMO SURGE A BIOENGENHARIA NA PERSPECTIVA DOS ENTREVISTADOS .............38

9. PRODUÇÃO E APLICAÇÃO DA BIOENGENHARIA NO BRASIL ............................................ 45

9.1 MAPEAMENTO DA BIOENGENHARIA NO BRASIL........................................................45

9.2 PRODUTOS E APLICAÇÕES DA BIOENGENHARIA NO BRASIL.................................52

9.3 APLICAÇÃO DA BIOENGENHARIA NA CARDIOLOGIA..............................................53

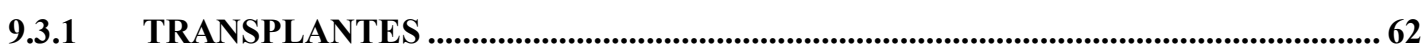

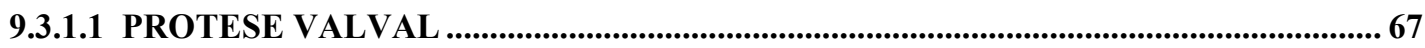

9.4 APLICAÇÃO DA BIOENGENHARIA NA ORTOPEDIA …................................................. 69

9.5 APLICAÇÃO DA BIOENGENHARIA NA ODONTOLOGIA .......................................... 82

9.5.1 HISTORIA DA PROTESE DENTARIA............................................................................ 88

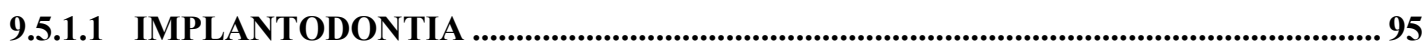

9.6. APLICAÇÃO DA BIOENGENHRIA NA OFTALMOLOGIA..........................................96

9.7. APLICAÇÃO DA BIOENGENHARIA NA MEDICINA REGENERATIVA.................... 99

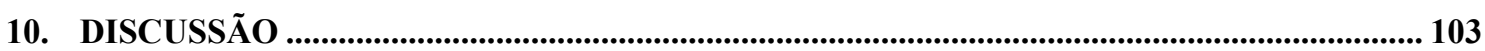

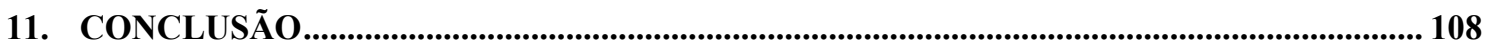

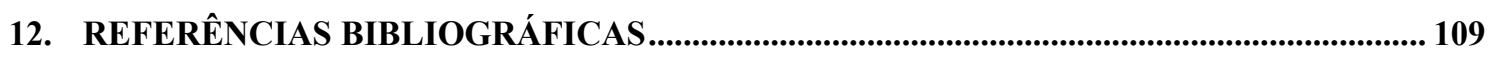

13. APENDICE A 


\section{INTRODUÇÃO}

A medicina dos povos que habitavam o Brasil na época do descobrimento apresentava, prática e teoricamente, as características fundamentais da denominada medicina primitiva, cujos fundamentos são a magia, o empirismo e a prática da cirurgia apenas em casos de imediata necessidade. Uns exemplos bastante interessantes são os silvícolas do Brasil que, como todos os povos primitivos, valeram-se da terapêutica de origem animal. Assim, conforme explica Tales de Azevedo (1949), davam os silvícolas grande importância ao poder curativo de certos ossos, bicos, garras e esporões de alguns pássaros, chegando a comer os órgãos genitais de certos animais, a fim de se manterem fortes e sadios. Até mesmo a mordedura de cobras, seguida de terríveis sintomas e, comumente, de morte, era tratada pelo brasilindio por meio de remédios da floresta e da própria fauna que o cercava.

As evidências mostram que essa terapêutica de origem animal trouxe muitos benefícios aos povos antigos. Dessa maneira, excetuando-se a bouba - mal endêmico, que atacou milhares de indivíduos, aleijando, mutilando e matando, após terríveis sofrimentos - e certas parasitoses inerentes ao meio, todas as doenças eram comuns à natureza humana. Por conseguinte, nenhuma moléstia infecto-contagiosa que, na Europa, dizimava populações inteiras, propagava-se no país. Conforme descreve Américo Vespúcio (1951), acerca do Brasil no período do descobrimento, "Os ares de si são temperados e bons; e pelo que pude deduzir de suas narrações, não há pestes nem doenças provenientes da corrupção do ar e se não morrem de morte violenta, vivem larga vida".

É interessante perceber que a comunicação recíproca entre a história e a medicina se faz a partir da herança comum de um modelo de conhecimento objetivando a reflexão acerca da posição de ambas no estágio atual da produção científica. Sabe-se que a medicina vem sofrendo modificações e abalos decorrentes das mudanças no processo histórico. Desse modo, no final do século XIX e início do século XX, os avanços na área médica têm sido bastante significativos. Apesar desse visível progresso, permanece, ainda, o embate entre duas forças antagônicas: de um lado, a fervorosa crença no saber científico e, de outro, a fé na eficácia da magia, das preces e das ervas. É fato que as doenças persistem e se caracterizam, muitas vezes, - uma vez que podem ser letais - como a moradia dos fantasmas de cada um e, nesse sentido, esse choque fará parte, possivelmente, por muito tempo, da historicidade humana.

A interação entre essas duas ciências, história e medicina, raramente tem sido abordada, seja por médicos seja por historiadores. Ao que parece, a preocupação com a história é bem mais antiga do que a preocupação com as doenças, que é bastante recente na história: data do século XX e se constitui um marco na revolução da medicina. Surge daí um viés comum: ambas se voltam para recuperar e reconstruir eventos cronologicamente ordenados. Faz-se de suma importância salientar que o entrelaçar da medicina com a história se dá pela transformação da primeira em objeto da segunda aspecto que, sem dúvida, justifica a posição da bioengenharia no Brasil no século XX; a situação desta ciência, sua origem e características serão agora, discutidas.

Como objetivo este trabalho reúne dados sobre a história da bioengenharia no Brasil, com uma pesquisa de campo que foi aplicada para os núcleos, que desenvolvem esta ciência no Brasil, uma parte foi desenvolvida através de entrevistas pessoais, por não termos referencias, como pode ser visto no anexo $\mathrm{A}$, outra parte foi feita através de 
bibliografia existente, completando com um formulário que foi enviado a empresas para se obter dados referentes ao desenvolvimento da bioengenharia no Brasil, anexo B.

No cápitulo três, que se refere à história e ciência, vamos apresentar um pouco a ciência historia e a ciência medicina juntas, o relacionamento destas ciências durante um período onde os profissionais sentem as mesmas dificuldades e necessidades para desenvolverem o seu trabalho, que muitas vezes se entrelaçam no tempo e não são registradas para uma grande maioria de pesquisadores, simplesmente ficam em alguns trabalhos de pesquisas.

No capítulo quatro, que fala sobre a história do Brasil e o surgimento das escolas de medicina, desde a primeira instituição totalmente brasileira, as escolas iniciaram com alguns cursos que com o tempo, sofreram modificações e melhoraram as suas escolas em universidades. Podemos ver o desenvolvimento econômico, a imigração que ocorreu no Brasil a partir de 1870 , a educação da população era de acordo com a elite da época.

No capítulo cinco, vamos comentar sobre as doenças que o Brasil, teve que enfrentar no início, suas causas e consequências. E a necessidade de se fabricar soros e vacinas no Brasil, para o combate das epidemas que assolaram o Brasil antes do século $\mathrm{XX}$.

No capítulo seis, A necessidade que o governo teve para a criação dos institutos de pesquisas, em São Paulo e Rio de Janeiro, fizeram o Brasil ser conhecido mundialmente, através da pesquisa e do desevolvimento em vários segmentos da ciência, mostrando a medicina brasileira era principalmente clínica e sanitária até 1900.

O capítulo sete, vai mostrar o que compõe a engenharia biomédica sendo uma área muito vasta, com pontos de tangência com outras áreas multidisciplinares, pode ser dividida em quatro sub-áreas: engenharia de reabilitação, informática médica, engenharia clínica ou hospitalar e bioengenharia.

Sendo a engenharia de reabilitação, conhecida também como tecnologia assistiva, auxilia na locomoção humana, as próteses, que podem ser internas e externas e também com o auxilio da fisioterapia, estimulação neuro-muscular, colocando na maioria dos casos o ser humano novamente em atividade funcional.

Na informática médica, objetiva desenvolver sistemas eletrônicos e mecânicos, é possível afirmar que ela é direcionada ao estudo, projeto e criação de software para administração de consultórios, telemedicina, redes neurais em super computadores ou sensoreamento remoto de guias de precisão em cirurgias cerebrais.

A engenharia clínica ou hospitalar cuida da operação de sistemas implantados com a eficiente utilização dos insumosdisponíveis, podendo atuar em várias intersecções com outras áreas da engenharia e das bio-ciências.

Finalizando este capítulo a bioengenharia que se dirige para a pesquisa pura, procurando aplicar os conceitos e métodos das ciências físicas e matemáticas a uma engenharia que se aproxime dos problemas da ciência humana, estando, por conseguinte preocupada com os problemas do corpo humano.

Com o capítulo oito afirmamos que a bioengenharia no Brasil ocorreu em duas fases: a primeira com a necessidade de fabricar soros e vacinas para a preservação e o combate das doenças, como mola propulsora a fundação dos institutos, sendo a segunda parte, após 1900, a instrumentação médica cirurgica.

O capítulo nove mostra a aplicação da bioengenharia no Brasil, através do mapeamento por estados feito um trabalho de localização de universidades, os cursos oferecidos e as linhas de pesquisas em engenharia Biomédica e Bioengenharia. Alguns que são grupos independentes, ou empresas que desenvolvem a pesquisa em 
bioengenharia, formando então um roteiro pelo Brasil da pesquisa realizada especificamente para a bioengenharia.

Ainda como produto e aplicação da bioengenharia no Brasil, a figura 10 mostra no ser humano os pontos onde pode ser aplicada a bioengenharia, através dos biomateriais que são utilizados na substituição ou reparo das partes do corpo humano, melhorando e prolongando a vida dos seres humanos.

Quanto à aplicação da Bioengenharia é importante enfatizar que a Bioengenharia pode auxiliar em alguns ramos da medicina tais como a Cardiologia, que é uma especialidade desenvolvida no Brasil graças à importância cada vez maior das doenças específicas do coração - importância que se justifica pela invalidez precoce e pela morte de muitas pessoas. Logo, esta ciência cresceu e se aprimorou pela necessidade, estendendo sua missão na área da pesquisa e aperfeiçoamento em coração. O Brasil dispõe, hoje, de serviços de cardiologia espalhados por todo o país, principalmente nas capitais e, sobretudo, nas cidades do interior do Estado; o trabalho é realizado por meio de equipes médicas e sua efetivação se dá - vale salientar - por meio do uso quase exclusivo de materiais cuja procedência é nacional.

Vamos comentar um pouco sobre os transplantes realizados no Brasil, apesar do transplante de órgãos não ser considerado como bioengenharia, vamos considerar somente as máquinas de circulação extracorpórea. Vamos comentar sobre a prótese valval e os tipos que são utilizadas no Brasil.

A aplicação da bioengenharia na Ortopedia, assim como muitas especialidades, desenvolveu-se no Brasil em razão da necessidade de se corrigir deformidades causadas por acidentes automobilísticos e acidentes de trabalho; o intuito desta ciência é, pois, desde o início, restabelecer funções do corpo humano, aliviando quaisquer sinais de dores. Os cirurgiões ortopédicos desenvolveram, assim, a habilidade de prevenir perdas importantes de função e, ainda, impedir, de fato, mortes inevitáveis. Os profissionais dessa área buscam a perfeição de sua arte, assegurando a melhora ao paciente no menor período de tempo, por meio do método mais seguro possível.

A Odontologia pode ser consultada, onde a aplicação da bioengenharia é bem desenvolvida, para que a nossa dentição seja preservada no momento em que - em virtude de problemas como a cárie ou doenças da gengiva, traumatismo ocasionando reabsorção óssea - isso não se faz possível. A prática da odontologia era, no passado, eminentemente empírico e artesanal: os dentes eram extraídos com métodos rudimentares para o alívio da dor. Para quem tinha condições financeiras, no entanto, esses meios elementares eram substituídos pela aplicação de diversos materiais. A Bioengenharia aplica-se à odontologia a fim de restaurar a função mastigatória, estética e fonética, podendo simplesmente minimizar os efeitos por meio das próteses dentárias.

Iremos falar também um pouco sobre a história da prótese dentária, como começou e se desenvolveu. Chegando até a implantodontia que passou por várias fases, dentro de um processo progressivo de evolução.

Já a Oftalmologia e sua aplicação podem ser vista como sendo a designação da especialidade que diagnostica e trata das doenças e desordens dos olhos; vale lembrar que este ramo da medicina inclui, ainda, as terapias com médicos e as cirurgias oculares.

Finalmente vamos falar sobre a Medicina Regenerativa é uma área emergente. Ela visa à substituição terapêutica de estruturas multicelulares, teciduais ou equivalentes a órgãos, tencionando o reparo de tecidos lesados ou degenerados por substitutos funcional e estruturalmente equivalente. Esta ciência pode, eventualmente, reparar, quando necessário, os tecidos lesados por traumas, doenças ou senescência. 
A metodologia utilizada para a pesquisa da História do Estado da Arte da Arte da Bioengenharia no Brasil, Século XX foi feita através de entrevistas gravadas, por médicos, engenheiros e pesquisadores que conhecem e desenvolvem a bioengenharia no Brasil, antes mesmo do século XX, em fitas e posteriormente transcritas, que se encontram em arquivo para consulta, e também de revisão bibliográfica, e do formulário que se encontra no anexo B.

Anexo A é o resultado dos colaboradores deste trabalho a lista das pessoas que disponibilizaram do seu tempo, para que outras pessoas soubessem como ocorreu a arte no desenvolvimento da ciência bioengenharia, engenharia biomédica no Brasil, anteriormente e durante século XX. Nas áreas descritas como Cardiologia, Ortopedia, Odontologia, Oftalmologia, Medicina Regenerativa.

Por meio dos resultados obtidos neste trabalho de história da bioengenharia foi, possível verificar que vários pontos visam a direcionar o leitor a um conhecimento de como se desenvolveu, evoluiu, e se tornou necessária para os seres humanos, a aplicação da bioengenharia.

A partir dos resultados obtidos neste trabalho é possível para o leitor a localização, tipo de segmento e a história a respeito da arte com que foi traçada a bioengenharia num ciclo de norte a sul, leste a oeste, do Brasil; tenciona-se evidenciar, sobretudo, a importância desta ciência para o futuro. 
2 OBJETIVO GERAL

Descrever o estado da arte da bioengenharia no Brasil, embasado na história da ciência e da medicina, evidenciando as áreas de Cardiologia, Ortopedia, Odontologia, Oftalmologia e Medicina Regenerativa. 


\section{A HISTÓRIA E A CIÊNCIA}

A interconexão entre história e medicina a partir da herança comum de um modelo de conhecimento implica resgatar o passado como vetor para a reflexão sobre a posição de ambas no estágio atual da produção científica. É neste sentido que o tema "A História do Estado da Arte da Bioengenharia no Brasil, século XX", busca fazer um levantamento não só da historicidade e os fundamentos comuns a esses dois campos do conhecimento e das articulações possíveis estabelecidas na bioengenharia, como também dos elementos a serem considerados na pesquisa sobre a imbricação entre os dois campos.

$\mathrm{Na}$ abordagem, por um lado, tanto os discursos epistemológicos da medicina quanto os da história estruturam-se narrativamente como meio de abarcar conhecimentos específicos acerca de seus objetos; por outro, observa-se que figura de linguagem, especialmente a metáfora, tem um papel importante na construção e divulgação desses dois campos do saber.

$\mathrm{Na}$ atualidade, a utopia dominante que vem se apresentando para toda a humanidade diz respeito à conquista da saúde. Historicamente pode-se-ia dizer que essa utopia corresponde ao nascimento, desenvolvimento e cristalização da chamada medicina preditiva. O que ela propõe é que o indivíduo, por um lado, tenha o poder de conhecer, através das biotecnociências (CASTIEL, 1998), seu patrimônio genético e por outro esteja apto a avaliar as influências ambientais e os modos de comportamento que podem favorecer a conjunção de dois fenômenos aleatórios: o inato e o adquirido.

Tanto esse conhecimento quanto essa capacidade de avaliação seriam vetores da manutenção da saúde, ancorado no auto conhecimento dos fatores de risco presentes nas moléculas no meio ambiente e nos estilos de vida. A tarefa a empreender seria a autogestão do capital saúde individual, da mesma forma como cada um gerencia seu capital imobiliário (RUFFIÉ, 1993).

Conhecer, gerir, prever. Como a história entraria ao lado da medicina na tríade passada, presente e futuro tão bem conhecido de todos. A pesquisa histórica tem algo a ver com a tensão entre o inato e o adquirido e com uma medicina que se pretende voltar, cada vez mais, para a manutenção da boa saúde. Haveria entre medicina e história fundamentos comuns de construção e interação.

É obvio que a história precisa estar presente não só porque responde às questões de ordem prática que a ação médica requer - tais como registro, coleta e classificação dos dados pertinentes às doenças e os doentes, como também porque se volta para o estudo da posição dos homens no mundo ao longo dos tempos, isto é, para as relações sociais de produção e poder que os homens estabelecem entre si e a natureza.

Através de revisão bibliográfica de cunho interdisciplinar, dados pessoais e entrevistas realizadas diretamente em universidades, núcleos, empresas, pretendem não só mostrar a existência de um paradigma de conhecimento comum a esses dois campos do saber, enquadrando na moldura de sua historicidade, como também apontar possíveis articulações e ingerências entre essas ciências.

No paradigma indiciário, enfatizou-se a problemática da narrativa tanto nos estudos e para o papel das figuras de linguagem, especificamente a metáfora, na produção e divulgação do conhecimento cientifico.

Só os seres humanos são capazes de contar uma história, porque somente eles sabem que algo aconteceu no passado, num tempo distante; tempo tão bem colocado 
pelas histórias bíblicas, que geralmente começam com "Naquele tempo...". Esse "naquele tempo" é o tempo dos seres humanos, portanto, o tempo humano. Assim se sabe também que um homem estava lá "naquele tempo". Ele não está aqui, contudo "estava lá". Somente os homens podem recortar as categorias lá e aqui e fazerem-nas constituintes de um espaço - o espaço humano. Somos historicidade, porque somos tempo e espaço. A pergunta com a qual Gauguin intitula seu quadro "De onde viemos, quem somos e para onde vamos" é a questão fundamental da historicidade. E ela não muda. $\mathrm{O}$ que varia são as maneiras como os homens responderam e respondem a essa questão, o modo como a consciência histórica formulou e formula respostas a ela (HELLER, 1993).

O desenrolar histórico de cada vida, em todos os momentos, coloca o desafio de tentar sobreviver, de lutar para romper um ciclo - nascer, crescer, amadurecer e morrer - cuja inviabilidade, na maioria das vezes, induz à adoção de componentes de cunho ideológico e/ou religioso para justificar ou amenizar. "Sendo assim, dada a importância da história, contaremos" o que por milhares de anos, o homem foi caçador. Ele teve de aprender a reconstruir as pegadas dos animais na neve, no barro ou na areia, teve de estudar os movimentos desses animais e classificar os seus odores. Movido pela necessidade, foi aprendendo a farejar, registrar, reconstruir, interpretar pistas insignificantes, mas imprescindíveis à sua sobrevivência e à de seus descendentes. As informações precisavam ser difundidas, pois a realidade não experimentada diretamente requeria ser compartilhada, comunicada e por isso, como sugere Ginzburg (1989), os caçadores teriam sido os primeiros a contar uma história, porque eram os únicos que transformavam as pistas tênues, deixadas pelos animais, numa série coerente de acontecimentos.

Foi a partir da observação e do registro atento dos eventos que surgiram as primeiras histórias; foi também observando e registrando cuidadosamente todos os sintomas, como afirmavam os hipocráticos, que se fizeram histórias acuradas de cada doença. A história, tão ligada ao empírico quanto à medicina, não ignora séries de fenômenos comparáveis e sua estratégia de conhecimento foi arquitetada através do exame de casos particulares, mesmo que o particular, no seu caso, se refira a um grupo ou a uma sociedade inteira. De sintonia à conjetura esboça-se, desde a medicina e os escritos gregos sobre a história, um modelo epistemológico indiciário (a busca de indícios) que aproxima as duas disciplinas e seus artífices. Como afirma Ginzburg (1989) “o historiador é comparável ao médico, que utiliza os quadros nosográficos para analisar o mal específico de cada doente. E como o do médico, o conhecimento histórico é indireto, indiciário, conjetural".

Os códigos de uma cultura, governando a linguagem, a percepção, as trocas, as técnicas, os valores, estabelecem para cada homem, desde o início, as ordens empíricas com as quais ele lida e entre as quais se sente à vontade. Por outro lado, há as interpretações filosóficas e científicas que explicam o existir das ordens, as leis, e o princípio que as governam. Entre esses dois polos se situa um domínio intermediário, em que a cultura se desvia das ordens que lhe foram prescritas pelos códigos primários, se separa deles e descobre que talvez essas ordens não sejam as únicas ou então as melhores. Emancipando-se, até certo ponto, de seus grilhões lingüísticos, perceptivos e práticos, a cultura superpõe a estes outros grilhões que os neutralizam, os excluem. Nesse processo, ela se vê frente à ordem em seu estado bruto. E é com base nessa ordem, concebida como fundação, que as teorias gerais sobre a ordenação das coisas são construídas. Essa região média, postulada por Foucault (1994) na medida em que se tornam manifestos os modos de ser da ordem, é a fundamental: "assim, em cada cultura, 
entre o uso do que se pode chamar de ordenação dos códigos e reflexões sobre a própria ordem, há uma experiência pura da ordem e seus modos de ser".

Apresentar o paradigma indiciário, como Ginzburg o faz, se torna possível, exatamente porque descontinuidades na episteme da cultura ocidental inauguraram o modo de conhecimento próprio da modernidade, permitindo o surgimento do homem moderno e de sua historicidade.

A historicidade, primeiro, não se revelou no homem, foi necessário que as coisas se dotassem de uma historicidade própria. Como estabeleceu com o trabalho, a vida e a linguagem, para que o homem, porque vive, trabalha e fala, descobrisse a si mesmo como tendo uma história e que esta, de certa forma, passasse a ditar o que ele pode ser, pensar e fazer. $\mathrm{Na}$ ordem empírica, o recuo das coisas possibilitou colocar a história como tendo uma origem humana e permitiu que o homem se sentisse no tempo (VAZ, 1997). Para cada ciência do homem, a história fornece um lar, as fronteiras de uma cultura na qual cada ramo do conhecimento pode ser reconhecido como tendo validade. Todavia, é também a história que limita o homem e corrói sua postulação de verdade como elemento universal - fora do tempo e do espaço humanos. Ela revela que, mesmo sem o saber, o homem "sempre esteve sujeito a determinações que podem se expressar pela psicologia, sociologia, e a análise da linguagem, por conseguinte, ele não é o objeto intemporal de um conhecimento que pelo menos no nível de seus direitos, deve ser pensado como sem idade" (Foucault, 1994).

Estabelecida a historicidade do modelo indiciário, chega-se à evidência de que caçadores, médicos e historiadores por ofício, partindo de um mesmo modelo de conhecimento- de pistas, indícios e sinais - "(re)constroem" casos particulares, dos quais abstraem generalizações. Tal como a semiótica médica, na sua dupla face diagnóstica e prognóstica, todas as teorias da história erguidas pelas mais diferentes correntes são formadas de saber voltadas do presente para o passado e para o futuro.

Partindo deste princípio, Hipócrates elaborou uma teoria - o sistema humoral que marcou o exercício da medicina por séculos. Para ele, a saúde e a doença repousavam no equílibrio entre a bile negra (melancolia), a bile amarela, a pituíta e o sangue. Estes, por sua vez, interagiam com os quatro elementos cósmicos (fogo, ar, água e terra), com as estações, com os estados climáticos (o quente, o frio, o seco, o úmido) e com os quatro pontos cardeais. $\mathrm{O}$ vocabulário e as concepções hipócritas permaneceram ainda vivos na apreensão social que se faz acerca das doenças, como por exemplo, quando se fala que o "sangue ferve" e que "engolir a raiva faz mal para o fígado". Entretanto, foi por sua insistência em fazer coincidir a teoria humoral com a observação do estágio da doença, que Hipócrates, até para os médicos de hoje, continua sendo considerado o pai da medicina científica.

Se à luz dos atuais conhecimentos sobre a teoria e metodologia da história, pode-se questionar a Heródoto seu título de historiador, sem dúvida, não se pode negar a ele o método de registro e de construção de fontes sobre a história da sociedade grega. $\mathrm{E}$ qual era esse método? Assim como Hipócrates, o antepassado remoto dos historiógrafos baseia-se na opsis - observação - e no acoë - o que se ouve - para produzir um testemunho de seu tempo.

Se a história é o reino do inexato, a medicina, desde a hipocrática até a exercida no século XIX - cujo eixo semiológico permanece até hoje - enquanto componente do arcabouço genérico de construção discursiva da doença, demonstrou que não bastava catalogar as doenças, pois em cada indivíduo ela assumia feições diferenciadas e que o corpo, locus por excelência da manifestação dos sintomas e sinais, era "por definição inatingível” (GINZBURG, 1989). 
No que tange ao aspecto histórico, o modo de estruturar as histórias dar-lhes um tom, combinar os temas e desdobrar as tramas imprime às histórias verbalizadas por cada ser humano uma natureza peculiar. Contendo uma visão de estar no mundo, as histórias de vivência do adoecer e da própria vida, absorvidas ao longo dos anos através de imagens, emoções, esperanças e incertezas, formam um panorama representativo do dinamismo de uma cultura, cujas raízes vinculam-se ao viver hodierno em coletividade, tanto numa determinada formação social, quanto numa ordem específica que se foi delineando com o desenvolvimento do processo histórico.

$\mathrm{Da}$ mesma maneira, as idéias culturais impregnam e saturam o discurso médico, e as concepções biomédicas sobre a saúde e a doença pressionam as mentalidades sociais. Estabelece-se, portanto, uma rede de interações e mediações num espaço no qual a racionalidade iluminista, da qual a atualidade é herdeira, pretendeu delimitar fronteiras de identidades absolutas. Na realidade, sutis, complicadas e enfumaçadas cercas delimitam as classificações com as quais se acostumou, mesmo a linguagem biomédica não pode escapar do que determinada cultura ordena sobre os corpos humanos.

O que se pretende apontar, portanto, é que os médicos, ao registrarem, estudarem e divulgarem suas experiências profissionais sobre o adoecimento de seus pacientes estão fazendo também narrativas sobre a história. Tal como os historiadores de ofício fazem surgir uma parcela de um certo tempo, de uma certa maneira de viver a saúde e a doença, reavaliando questões cuja importância transborda as margens do campo biológico para referir-se também às estruturas do viver sócio-coletivo.

O diagnóstico considerado no século XIX como arte de transformar sintomas em sinais acabou significando correlacionar a observação ao pé do leito com as descobertas que a moderna tecnologia médica oferece e manifestações subjetivas com lesões objetivas. E também implicou a transformação da maneira pessoal de dar conta do sofrimento num discurso médico profissional que transcodifica o subjetivismo incoerente num texto interpretável. Essa conversão da pesquisa semiológica, que se traduz no raciocínio diagnóstico, não pode prescindir nem da história pessoal e familiar do doente, nem de uma - propositadamente entre aspas "história natural da doença". E como ambas dependem da leitura de sinais/lesões e sintomas, é necessário levar em conta a confiabilidade dos indicadores e a maneira como são processados, reportados e documentados (EPSTEIN, 1995).

Num sentido amplo, então, as histórias médicas contidas na anamnese, acrescidas do registro de resultados obtidos mediante o exame clínico e o recurso aos exames complementares a que a mais sofisticada tecnologia permite recorrer, por se constituírem em fontes primárias sobre a doença e o doente, são os materiais sobre o qual o médico se debruça para começar a "interpretar" os "fatos" e, a partir daí, construir seu diagnóstico.

A problemática do relacionamento entre a explanação histórica e os mecanismos explanatórios na ciência - um tema importante para a história clínica que cada médico produz sobre seu paciente - instiga e faz emergir reflexões que, principalmente nas décadas após a Segunda Guerra, têm sido sistematizadas por pensadores dos mais diversos campos do conhecimento. Uma delas, por exemplo, é a do entendimento do corpo como uma formação discursiva - trazida por Foucault (1977) em seus estudos sobre a sexualidade e a medicina - e também a da historicidade, porque ambas se complementam. Os corpos humanos são portadores não só de agentes patogênicos, assim como de histórias que explicam suas vidas. A necessidade de se construir essas histórias/narrativas sublinham os modos pelos quais as noções de saúde e doença são culturalmente produzidas. 
Desse modo, todo corpo humano participa de uma coletividade que não pode ser entendida sem suas concepções de mundo, não é apolítica e/ou afastada das contingências históricas dos sistemas sociais e de crenças (EPSTEIN, 1995).

Uma multidão de significados pode ser encontrada nos arquivos médicos. As histórias médicas dos pacientes revelam, em suas múltiplas formas, aspectos culturais que organizam, institucionalizam e controlam não só os cuidados com a saúde, mas também a própria maneira como se estruturam as especialidades médicas e as habilidades dos profissionais médicos em lidar com o sofrimento de seus pacientes. Revelam também as concepções dos médicos sobre as doenças e de que forma constroem a narrativa, isto é, como assumem sua historicidade e que consciência histórica possuem do mundo e de si.

A medicina vem sofrendo modificações e abalos correlatos às mudanças no processo histórico. Entretanto, da Antiguidade até os avanços mais recentes, as atitudes frente ao adoecimento pouco se alteraram. A fervorosa crença no saber científico coexiste com a fé na eficácia da magia, das preces e das ervas. As doenças persistem sendo a moradia dos fantasmas de cada um porque podem ser letais. Por isso, elas fazem parte da historicidade humana. Elas não pertencem somente ao relato dos progressos da biotecnociências, mas integram a história dos saberes e ações articuladas às estruturas sociais, às instituições culturais criadas pelos homens, ao entendimento que possuem da realidade (LE GOFF, 1991).

Se a medicina defronta-se com o sofrimento, a história também. Todavia, a interação das duas raramente tem sido abordada seja por médicos, seja por historiadores. Da parte da história, a preocupação das doenças é bastante recente, datando de trinta anos para cá; de parte da medicina, porém, a preocupação com a história é bem mais antiga. Desse encontro surge um viés comum: ambas se voltam para recuperar e reconstruir "eventos" cronologicamente ordenados, produzindo obras de cunho eminentemente fatual.

Quando o historiador se debruça sobre a doença ou as práticas médicas é para delas recompor o passado e traçar sua evolução até os dias de hoje; quando o médico se debruça sobre a história é para usar os métodos clássicos da disciplina para traçar o progresso do conhecimento médico ao longo do tempo (LE GOFF, 1991).

A produção historiográfica mais recente sobre as doenças raramente escapa desse modelo. Caso se escolha a coletânea mais conhecida sobre a história das doenças, aquela organizada pelo historiador francês Jacques Le Goff (1991) vê-se que somente um ensaio (MOULIN, 1991) oferece a interpretação, baseada em Foucault, que realiza uma discussão de conteúdo, imbricando técnica médica com atitude crítica/analítica e articulando-as à percepção que os atores sociais contemporâneos têm dos avanços na área biomédica e de produção de fármacos.

Um historiador como Porter (1992), por exemplo, há anos vem se dedicando à história da medicina, sempre estabelecendo relações entre elas, as doenças e os médicos, traçando um painel geral sobre o desenrolar do exercício clínico. Sua preocupação é com a longa duração e com as modificações engendradas ao longo de um continuum evolutivo.

Desde finais da década de sessenta, pesquisadores ligados à antropologia e a sociologia médica, à psicanálise e à própria clínica vêm desenvolvendo trabalhos sobre o que se convencionou chamar de narrativas de doenças (illness narratives). As narrativas assumiram grande importância no estudo das doenças crônicas, sendo encaradas como caminhos para o entendimento dos esforços dos clientes/pacientes em lidar com suas vidas, sobretudo diante dos problemas de quebra de identidade que esse tipo de doença acarreta. 
Autores como Kleinman (1988) a quem se deve a expressão illness narratives - concentra-se na categoria sofrimento e postulam as narrativas como a forma pela qual os doentes modelam e dão voz a seus padecimentos. Hydén (1997) afirma que, teoricamente, o conceito de narrativa primeiro ocupou um espaço periférico no campo do conhecimento sociológico das doenças, mas hoje ocupa lugar central por permitir captar aspectos nucleares da experiência do adoecimento em seus contextos sociais específicos.

Nesse sentido, esses trabalhos partem da postura de dar voz aos doentes, como fica patente no título do capítulo um do livro do sociólogo Arthur Frank (1995): "Quando corpos precisam de vozes".

Tendo por base os teóricos da pós-modernidade e sua própria experiência com a doença, Frank propõe que o "contador de histórias ferido" (wounded storyteller) fala não sobre o seu corpo doente, mas através dele. A doença crônica estabelece o caos e o doente perde sua bússola. A narrativa personalizada, não mais "meta" ajuda-o a reencontrar o caminho e o torna participativo, integrante e conhecedor do próprio adoecimento. Morris (1998) outro sociólogo que se dedica ao estudo da dor e da medicina, pugna por uma doença biocultural. Ele segue a concepção teórica pósmodernista de Lyotard, nos mesmos moldes de Frank, preocupando-se em sugerir a narrativa como instrumento ético de discussão dos rumos tomados pela biotecnologia, e também como meio de romper o silêncio imposto ao doente pelo sofrimento.

Por sua vez, Hawkins (1993) encara as narrativas de doença sob a perspectiva de gênero literário. Seu trabalho conduz o leitor pelo que ela chama de patografias, e, sobretudo, pelos mitos que as sedimentam. A história das idéias se faz presente, embora encarada sob uma perspectiva interdisciplinar com o estudo do campo literário em sentido escrito. Para argumentação narrativa estão presentes nesse tipo de literatura: a "didática", baseada numa experiência vivida que é passada aos outros, no sentido de infundir-lhe confiança e esperança; a "raivosa" (angry) que se volta contra a dor produzida nos corpos pelas técnicas médicas invasivas sem, contudo, atacar a figura do médico; e finalmente o tipo de argumentação que qualifica como "de positividade da mente" mais crítica do saber médico, que pugna pela integração corpo/mente, reconhecendo as funções curativas das maneiras positivas de pensar.

Ressalta-se que historiografia, História e história são termos que devem ser vistos como portadores de significados diferenciados. Por historiografia compreende-se nada mais que a história do discurso que os historiadores de ofício vêm sustentando sobre o seu passado (CARBONELL, 1987) por História entende-se a disciplina institucionalizada que fornece os instrumentos conceituais e teóricos, além do conhecimento historiográfico, à formação do historiador. Finalmente por história, entende-se o processo humano do viver coletivo ao longo dos tempos e no aqui e agora, isto é, aquilo que os homens cotidianamente viveram no passado e vivem hoje, estabelecendo relações entre si e as coisas.

Essa repartição de campos discursivos responde à necessidade de pontuar as ambigüidades acarretadas pela não diferenciação existente entre a ciência da história "a ciência dos homens no tempo" - seguindo Bloch, 1976 - e que os homens efetivamente realizaram e realizam. E fundamentalmente, serve para indicar uma dinâmica que, na sua totalidade, escapa à racionalidade e seu modus operandi, pois os homens deliberam, possuem objetivos, fins, intenções, pulsões, desejos, como bem aponta Veyne (1983) impossíveis de serem captados na sua globalidade, porque a história que se vive é, na verdade, o reino do impreciso e cabe assumir que o método da História é inexato; que ela quer fazer reviver, mas só pode reconstruir... Quer tornar as coisas contemporâneas, mas, ao mesmo tempo, tem que reconstruir a distância e a 
profundidade da lonjura histórica Ricoeur (1961) Enfim, o nome da disciplina que se volta para o estudo da história é um nome próprio - História - dado a uma forma de saber e produzir sobre o que se faz: história.

Da mesma maneira, poder-se-ia, de forma esquemática, traçar um paralelo entre historiografia médica, medicina e doença. A primeira, como é óbvio, trataria dos escritos sobre história da medicina, das doenças e dos doentes; a segunda seria a disciplina responsável pelo soerguimento de uma teoria sobre as doenças; e finalmente, a terceira seria a doença propriamente dita - tal qual ocorre com a história, que segundo os estudos de Camargo Junior (1994) no contexto do saber médico carece de uma conceituação geral sobre o que ela seria.

O que se presentifica, entretanto, não é a sobreposição da medicina e da história ou vice-versa, misturando-as como ingredientes de um coquetel, mas sim a necessidade de entendê-las enquanto ciências aplicadas e voltadas para a realidade vivida.

A cultura determina a história social dos corpos, define como eles se tornaram objetos de curiosidade e de poder. O homem, confrontando com o desenvolvimento do saber do qual seria o primeiro beneficiário, mas do qual, sem dúvida, sente também os efeitos perversos, reposta-se ao velho mito do aprendiz de feiticeiro. São as intervenções biotécnicas da medicina, das quais o corpo tornou-se objeto, que mapeiam seu caminho. A bioética torna-se cada dia mais ambivalente, pois à medida que procura preservar os corpos, termina por sobredeterminar suas formas. O corpo torna-se "o corpo proibido: ao mesmo tempo protegido e interditado" (BADOU, 1994).

O inventário do material genético e o conhecimento dos efeitos epigenéticos sobre a saúde marcam o nascimento da medicina preditiva, que tem por finalidade definir os pontos fracos de cada indivíduo, indicar os perigos os quais cada ser em particular é mais potencialmente vulnerável. Nas palavras de Ruffié (1993), trata-se de uma medicina do dever que permitirá conhecer o "capital saúde" que cada um deverá administrar para melhor e mais tardiamente envelhecer e morrer.

A história procura o mesmo caminho. Se sua aproximação dos procedimentos teórico-metodológicas da sociologia, da antropologia e da economia trouxe avanços para a produção historiográfica, também a afastou, pelo menos até os finais da década de sessenta, de tudo o que era documental e experimental, e oficialmente incluindo no reino da "ciência pura" e, portanto passível de fornecer séries estatísticas e bases para o estabelecimento de leis gerais de funcionamento.

Nesse contexto, a reabilitação da narrativa, com o desenvolvimento das pesquisas na área da história sócio cultural, representam menos uma volta a um estilo de escrita predominante no século XIX, e mais uma preocupação com o cotidiano da vida, com o sofrimento e com a dor experimentada pelos seres humanos comuns. Ora, essa reabilitação também passa a se consubstanciar não só nos trabalhos de médicos - vejase Kleinman e Sacks, entre outros - mas, igualmente, nos esforços da antropologia, da sociologia e da crítica literária, Frank, Morris, Epstein, Hunter, Hawkins, para ficar com os já citados, voltados para a complexidade com que se revestiu a medicina na atualidade.

Desse modo, os sintomas e sinais não são somente da ordem do biológico. Eles são sociais e é tão claro que se constroem na narrativa que de forma alguma podem ser considerados estritamente naturais. $\mathrm{Na}$ verdade, eles fazem parte das redes que tecem a história do mundo, redes estas que são concomitantemente reais: como a natureza, contadas/narrativizadas, como as falas, e coletivas como a sociedade (LATOUR, 1994).

Os corpos que os portam são, por conseguinte tramas de natureza, sentido, história, valores, ficção, religiosidade, tecnologias... E os médicos que sobre eles 
debruçam, procurando a doença, participam não apenas do registro cuidadoso daquilo que observam, mas também da própria construção do que lhes é dado observar.

Ao exercitarem a função de produzir histórias, tanto o historiador quanto o médico assumem a narrativa como uma modalidade de escrita sobre a história, incluindo aí os elementos imaginários que penetram qualquer narração. Isso, contudo, não implica dizer que a história e medicina são a mesma coisa e que ambas são ficção, mas tão somente que, se nas duas há a construção de um enredo, porque relacionan elementos dispersos e ligam eventos e/ou acontecimentos isolados, elas assim o fazem de forma constrangida, construindo sua objetividade que é permanentemente confrontada e reformulada por novas e complexas interações biológicas, culturais, sociais, ecológicas, entre outros fatores.

Pesquisar a história da ciência e investigar o contexto no qual as descobertas eram feitas. Um exemplo dessa abordagem é o trabalho desenvolvido por Stengers (1989) que põe em pauta a questão do poder da ciência e enuncia a ilusão de que as atividades mensuráveis, quantificaveis, seriam as únicas a garantir sua eficácia. Essa ilusão reposta-se à insegurança e ao medo de assumir riscos que são inerentes a qualquer posição que se pretenda científica.

Com o surgimento da anátomo-clínica "o conhecimento da vida encontra sua origem da destruição da vida, e no seu extremo oposto; é na morte que a doença e a vida falam a sua verdade" (FOUCAULT, 1963) É a partir daí que não se pode deixar de conferir um sentido ao conceito de doença, pois, na medicina, enquanto técnica de curar, fincam-se na vida.

De forma análoga, contudo diversa, um indivíduo sadio, por exemplo, numa cadeira de rodas em decorrência de um acidente automobilístico ou uma pessoa portadora de um cromossomo a mais, como na mais comum das anomalias genéticas, a Síndrome de Down, padecem de condições alteradas. Sua visibilidade socio-cultural como "diferentes" produz uma espécie de invisibilidade pública. Muitas vezes encontram-se literalmente apagadas porque os outros se recusam a vê-las. O que está em jogo quando se atribui a essas pessoas, que podem funcionar em casa, no trabalho, na esfera pública e privada, a condição de doentes? Estão se sobredeterminando suas enfermidades de base às suas capacidades de atuação, porque por definição suas normas vitais estão comprometidas. É a conceituação da doença, então que constrói a realidade.

Portanto, buscar uma investigação que articule os saberes médico e historiográfico, trabalhando a partir da herança arcaica de um paradigma, poderá trazer a dimensão singular do adoecimento sem, todavia, perder-se de perspectiva o caráter geral que a ciência deve assumir. Esse caráter geral não pode ser confundido com banalização nem muito menos com generalizações impostas de cima para baixo, na tentativa de transformar tudo o que existe em mensurável. Parece ser esse um impasse que se luta por romper sem, contudo se perder a credibilidade científica. O mito do numérico, como sinônimo de ciência, é também uma ilusão utópica. 


\section{A HISTÓRIA DO BRASIL E O SURGIMENTO DAS ESCOLAS DE MEDICINA.}

A ciência no Brasil acompanhou, de modo significativo, o padrão já descrito para a América espanhola. Os mesmos fatores que operaram na América espanhola para limitar a ciência - a má qualidade da ciência do país transmissor, uma política de imperialismo cultural e a falta de um rompimento decisivo com as tradições coloniais na época da independência - ajudaram a modelar a evolução da ciência colonial no Brasil. Faz-se interessante comentar que as diferenças entre o Brasil e os países da América espanhola são proveniente do maior isolamento entre este país e o resto do mundo, bem como, do prosseguimento da cultura colonial que aqui se deu em pleno século XX.

Como se sabe, os primeiros a estudar a fauna, a flora e as populações do Brasil foram os exploradores e os colonos. É importante reconhecer, no entanto, a diferença existente entre os holandeses e os portugueses - povos que exploraram o Brasil no momento da colonização. Dessa maneira, os esforços científicos portugueses não podem se comparar aos dos holandeses. Apenas para citar um exemplo, o primeiro observatório astronômico de que se teve notícia foi construído na colônia holandesa de Pernambuco entre 1630 e 1654, sob a liderança do Príncipe Maurício de Nassau. Entretanto, a experiência holandesa com a ciência no Brasil terminou neste mesmo ano (1654), quando os holandeses foram expulsos do Brasil pelos portugueses. Desse modo, enquanto a experiência científica holandesa prosperou no Brasil, os esforços brasileiros tornaram-se limitados em razão da política mercantilista da Coroa portuguesa, que, erroneamente, apenas considerava o país como uma rica fonte de matérias-primas para exportação (SANTOS FILHO, 1980).

A situação econômica não era das mais favoráveis. O comércio com as Índias ocidentais havia declinado e Portugal apoiou-se, cada vez mais, no tabaco, no pau-brasil e, acima de tudo, no açúcar, que os navios mercantes portugueses e ingleses levaram do Brasil a Lisboa a fim de serem distribuídos para toda a Europa. O ouro foi descoberto em Minas Gerais, proporcionando, ao Brasil e à metrópole portuguesa, uma nova fonte de riqueza que permaneceu até a metade do século XVIII. É preciso salientar que a descoberta do ouro por bandos errantes provocou uma mudança da população brasileira para longe da costa, em direção ao interior onde o ouro era encontrado (FRAGOSO, 1990).

O advento do ouro ocasionou, pois, um acentuado menosprezo dos brasileiros pela agricultura e, de maneira inversa, um apego significativo à mineração. $\mathrm{O}$ Brasil alcançou, então, uma situação de muita prosperidade, tornando-se, por volta de 1750 , em muitos aspectos, mais ditoso do que Portugal.

Uma vez que era proeminente os interesses da metrópole pela matéria-prima colonial, muitos esforços científicos do século XVIII foram feitos com o intuito de coletar informações acerca dos novos produtos que apresentassem possível valor comercial. Ao contrário dos espanhóis, no entanto, os portugueses não transferiram para o Novo Mundo (Brasil) as instituições educacionais e culturais do Velho Mundo (Europa). Logo, nenhuma universidade foi fundada até o século XIX, e a educação médica formal esteve, no Brasil, fadada, até 1808, ao descaso e conseqüente retardo de suas funções (NOVAIS, 1983).

Apenas para que se tenha uma idéia do atraso cultural brasileiro, quase toda educação acima do nível da escola secundária era ministrada em Portugal. Dentro do Brasil, os missionários jesuítas continuaram como os principais transmissores do conhecimento europeu até 1759 , porém, seu entusiasmo para expandir suas atividades 
educacionais foi interrompido pelas autoridades portuguesas, que temiam o estabelecimento, no Brasil, de quaisquer instituições que pudessem rivalizar com o ideário português. Assim, até o fim do período colonial, que se estendeu de $1500 \mathrm{a}$ 1601, a ciência no Brasil esteve muito atrasada em relação à América Espanhola (CAMENIETZKI, 2000).

Quando o fornecimento do ouro começou a diminuir, o Marquês de Pombal expulsou os jesuítas do Brasil e, conseqüentemente, muitas das escolas brasileiras foram fechadas. Para contrabalançar esse golpe na estrutura educacional do Brasil, Pombal, influenciado pelo pensamento filosófico, estabeleceu várias novas cadeiras de ciências. Então, financiados pelo governo, inúmeros profissionais foram enviados à Europa a fim de melhorar seus conhecimentos relacionados a mineralogia, a geologia e, particularmente, a arte de testar minérios. É útil salientar que a ênfase do pensamento filosófico no aprendizado útil - a nova geração que passou a se dedicar ao estudo da história da ciência no país - também começou a ter a sua influência na formação de novas sociedades científicas tanto em Portugal como no Brasil (CARVALHO, 1978).

Um exemplo dessa disseminação do pensamento filosófico foi a criação, em 1772, da Sociedade Científica do Rio de Janeiro; tal evento constituiu-se como um contraste marcante em relação às sociedades literárias e históricas anteriores, que eram, geralmente, transitórias. Por conseguinte, as sociedades científicas foram concebidas com a finalidade de difundir os conhecimentos científicos. Apenas a título de curiosidade, compareceram à primeira reunião da Sociedade Científica do Rio de Janeiro quatro cirurgiões, três médicos, dois farmacêuticos e um fazendeiro. Os campos da botânica, zoologia, química, física e mineralogia estavam todos representados, e, desse modo, eram realizadas freqüentemente conferências públicas. Em 1799, o grupo mudou seu nome para Sociedade Literária do Rio de Janeiro, continuando, entretanto, seu trabalho científico até 1794, quando foi fechado (AZEVEDO, 1885).

Faz-se necessário comentar, agora, as conseqüências, para o Brasil, da vinda da família real. Assim, a transferência da família real de Lisboa para o Rio de Janeiro, em janeiro de 1808, ocasiona profunda transformação na colônia. D. João VI chega, numa esquadra de navios de guerra e mercantes, acompanhados por sua mãe idosa - Maria I, chamada a Piedosa - e por inúmeros administradores da corte, nobres e suas famílias, oficiais e padres, que faziam parte da sociedade portuguesa; ao todo, cerca de quinze mil pessoas (MOACIR, 1938).

Em 1815, o Brasil foi elevado à condição de Reino, e o país colonial tornou-se o quartel-general administrativo do Império Português, o que significou a transferência de poder da metrópole para a colônia. A vida brasileira, em virtude desse acontecimento político, foi alterada dramaticamente. Para se ter uma idéia dessa mudança, um dos primeiros atos do príncipe regente foi abrir os portos do Brasil ao comércio europeu. Outra atitude do príncipe foi abrir ao público uma biblioteca real de 60.000 volumes. Desse modo, foram tomadas medidas para remediar a situação criada pela falta de facilidades educacionais no Brasil, bem como a dificuldade de continuar a depender de um fornecimento de médicos e engenheiros oriundos da Europa. Como se vê, de uma maneira geral, muito pouco havia na sociedade brasileira para encorajar o estudo desinteressado e o desenvolvimento da ciência e da tecnologia (EWBANK, 1976).

Em 1838, foi fundado o Instituto Histórico e Geográfico Brasileiro e, em períodos posteriores, a ciência foi estimulada no que diz respeito a agricultura e a medicina. Portanto, "da noite para o dia", as oportunidades para o progresso da ciência no Brasil aumentaram significativamente. A preocupação mais premente era, no entanto, a escassez de médicos. Assim, foram consentidos cursos médicos e cirúrgicos nos hospitais militares da Bahia e do Rio de Janeiro. Mais tarde, tais cursos foram 
regularizados como Academias de Medicina e Cirurgia, estando os professores autorizados a ensinar e a organizar escolas de medicina (AZEVEDO, 1963).

A primeira instituição nacional de história natural criada, aqui, foi o Jardim Real, mais tarde chamado de Real Jardim Botânico. O intuito era justamente aclimatar plantas estrangeiras para seu uso no Brasil. Embora o país tivesse sofrido um certo número de mudanças políticas formais nas primeiras décadas do século, inclusive a separação de Portugal seguida pela independência em 1822, a monarquia foi preservada até 1889 e permaneceu como símbolo da continuidade em relação ao passado colonial do Brasil (JOBIM, 1984).

É curioso observar que, mesmo havendo um rápido crescimento das cidades do Rio de Janeiro, São Paulo e Bahia (Salvador), o ponto essencial da sociedade brasileira ainda estava nas grandes plantações - do açúcar e, depois de 1840, do café - e na economia de exportação que elas sustentavam. Isto se deve, com certeza, ao fato de ser a cultura brasileira, nesse período, predominantemente agrícola, hierárquica e patriarcal. Além disso, a persistência da escravatura até 1888 contribuiu, possivelmente, para a sobrevivência de uma sociedade de plantadores que pouco exigia da ciência (STEPAN, 1976).

Gradualmente, entretanto, muitos fatores foram colaborando para o progresso brasileiro em diversos aspectos. A revolução dos transportes começou vagarosamente e, só no século $\mathrm{XX}$, as estradas de ferro iniciaram, de fato, o processo de ligação entre as diferentes regiões do vasto país. Observe na figura 1, uma das primeiras máquinas a vapor utilizadas no início da ferrovia no Brasil.

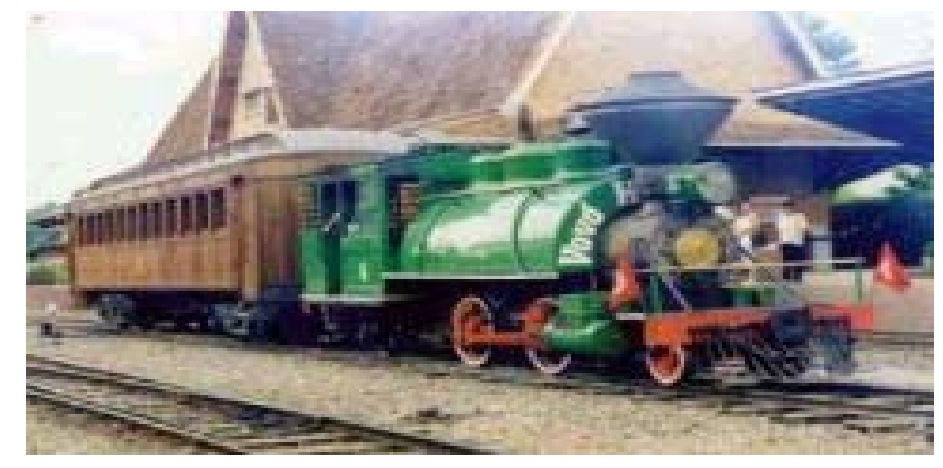

Figura 1 - Implantação da ferrovia no Brasil Fonte -Disponível em: $<$ http://www.senado.gov.br.web/historia Acesso em 20 dezembro 2003

A imigração, que se acelerou rapidamente após 1888 - quando os donos de plantações procuraram descobrir um substituto para o trabalho escravo -, inicialmente não perturbou o ritmo da vida brasileira. Muitos imigrantes foram atraídos do sul da Itália e não tinham instrução nem habilidades técnicas. Observe na tabela 1 que o número das pessoas que imigraram para o Brasil após 1870 foi muito alto. Eles foram, então, rapidamente absorvidos pelas estruturas sociais existentes. A indústria também se desenvolveu vagarosamente, retardada, em parte, pela falta de leis de responsabilidade, limitadas antes de 1888 (TURAZZI, 1988). 
Tabela 1 ENTRADA DE IMIGRANTES NO BRASIL - 1870/1907

\begin{tabular}{|c|c|c|c|c|c|c|c|}
\hline Ano & Alemães & Espanhóis & Italianos & Portugueses & Russos & Diversos & TOTAL \\
\hline 1.870 & 6 & 38 & 7 & 4.458 & 0 & 649 & 5.158 \\
\hline 1.871 & 296 & 510 & 1.626 & 8.124 & 4 & 1.871 & 12.431 \\
\hline 1.872 & 1.103 & 727 & 1.808 & 12.918 & 7 & 2.656 & 19.219 \\
\hline 1.873 & 1.082 & 0 & 0 & 1.310 & 41 & 12.309 & 14.742 \\
\hline 1.874 & 1.435 & 0 & 5 & 6.644 & 30 & 12.219 & 20.333 \\
\hline 1.875 & 1.308 & 39 & 1.171 & 3.692 & 956 & 7.424 & 14.590 \\
\hline 1.876 & 3.530 & 763 & 6.820 & 7.421 & 3.011 & 9.202 & 30.747 \\
\hline 1.877 & 2.310 & 23 & 13.582 & 7.965 & 2.115 & 3.473 & 29.468 \\
\hline 1.878 & 1.535 & 929 & 11.836 & 6.236 & 1.904 & 2.016 & 24.456 \\
\hline 1.879 & 2.022 & 911 & 10.245 & 8.841 & 7 & 762 & 22.788 \\
\hline 1.880 & 2.385 & 1.275 & 12.936 & 12.101 & 426 & 1.232 & 30.355 \\
\hline 1.881 & 1.851 & 2.677 & 2.705 & 3.144 & 305 & 866 & 11.548 \\
\hline 1.882 & 1.804 & 3.961 & 12.428 & 10.621 & 19 & 756 & 29.589 \\
\hline 1.883 & 2.348 & 2.660 & 15.724 & 12.509 & 10 & 764 & 34.015 \\
\hline 1.884 & 1.719 & 710 & 10.102 & 8.683 & 457 & 3.219 & 24.890 \\
\hline 1.885 & 2.848 & 952 & 21.765 & 7.611 & 275 & 1.989 & 35.440 \\
\hline 1.886 & 2.414 & 1.317 & 20.430 & 6.287 & 146 & 2.892 & 33.486 \\
\hline 1.887 & 1.147 & 1.766 & 40.157 & 10.205 & 0 & 2.690 & 55.965 \\
\hline 1.888 & 782 & 4.736 & 104.353 & 18.289 & 0 & 5.093 & 133.253 \\
\hline 1.889 & 1.903 & 9.012 & 36.124 & 15.240 & 0 & 2.967 & 65.246 \\
\hline 1.890 & 4.812 & 12.008 & 31.275 & 25.174 & 27.125 & 7.080 & 107.474 \\
\hline 1.891 & 5.285 & 22.146 & 132.326 & 32.349 & 11.817 & 12.837 & 216.760 \\
\hline 1.892 & 800 & 10.471 & 55.049 & 17.797 & 158 & 1.928 & 86.203 \\
\hline 1.893 & 1.368 & 38.998 & 58.552 & 28.986 & 155 & 6.746 & 134.805 \\
\hline 1.894 & 790 & 5.986 & 34.872 & 17.041 & 57 & 2.238 & 60.984 \\
\hline 1.895 & 973 & 17.641 & 97.344 & 36.055 & 275 & 15.330 & 167.618 \\
\hline 1.896 & 1.070 & 24.154 & 96.505 & 22.299 & 592 & 13.512 & 158.132 \\
\hline 1.897 & 930 & 19.466 & 104.510 & 13.558 & 569 & 7.329 & 146.362 \\
\hline 1.898 & 535 & 8.024 & 49.086 & 15.105 & 258 & 5.101 & 78.109 \\
\hline 1.899 & 521 & 5.399 & 30.846 & 10.989 & 412 & 6.462 & 54.629 \\
\hline 1.900 & 217 & 4.834 & 19.671 & 8.250 & 147 & 7.181 & 40.300 \\
\hline 1.901 & 166 & 8.584 & 59.869 & 11.261 & 99 & 5.327 & 85.306 \\
\hline 1.902 & 265 & 3.588 & 32.111 & 11.606 & 108 & 4.526 & 52.204 \\
\hline 1.903 & 1.231 & 4.466 & 12.970 & 11.378 & 371 & 3.646 & 34.062 \\
\hline 1.904 & 797 & 10.046 & 12.857 & 17.318 & 287 & 4.859 & 46.164 \\
\hline 1.905 & 650 & 25.329 & 17.360 & 20.181 & 996 & 5.779 & 70.295 \\
\hline 1.906 & 1.333 & 24.441 & 20.777 & 21.706 & 751 & 4.664 & 73.672 \\
\hline \multirow[t]{2}{*}{1.907} & 845 & 9.235 & 18.238 & 25.681 & 703 & 13.085 & 67.787 \\
\hline & 56.416 & 287.822 & 1.208 .042 & 519.033 & 54.593 & 202.679 & 2.328 .585 \\
\hline
\end{tabular}

Fonte: http://www.memorial do imigrante.sp.gov.Br Acesso em 20 de dezembro 2003

A educação secundária era um privilégio gozado por poucos. A ênfase na educação era mais literária do que científica, refletindo, pois, interesses das elites. Se a ciência não se desenvolveu no Brasil no século XIX, em resumo, foi porque se atribuiu 
pouco valor ao estudo da ciência em razão da síndrome do impacto da mesma - estudo só atingia aos nobres e o interesse do aprendizado era sempre o mesmo. Afora isso, a industrialização ainda não havia progredido até o ponto onde pudesse proporcionar novas fontes de apoio para a ciência.

O fim da escravatura foi seguido pelo colapso da monarquia em 1889, o exílio do Imperador D.Pedro II e, ainda, pelo significativo progresso da República Brasileira no que diz respeito a toda estrutura da educação secundária. As mudanças na área científica ocorreram aos poucos e foram estimuladas por uma variedade de fatores. Um fator crucial foi, indubitavelmente, a presença de médicos e cientistas brasileiros muitos deles formados na Europa - que estavam entre os porta-vozes mais importantes para a melhoria da ciência brasileira. Os cientistas estrangeiros também contribuíram para o desenvolvimento da ciência no Brasil trazendo para cá idéias e modos de organização europeus. Além disso, a ameaça de doenças epidêmicas começou a estimular as autoridades locais e federais a organizarem órgãos de saúde pública à medida que a ciência progredia (FERRI et al, 1979).

É importante lembrar que o desenvolvimento econômico e industrial nas áreas dotadas de eletricidade e estradas de ferro começou a criar novas fontes de emprego para os engenheiros. Reformas tiveram lugar nas escolas militar e de medicina do Rio de Janeiro. A separação das engenharias militar e civil tinha começado em 1858, quando os primeiros diplomas de engenharia civil foram oferecidos e foi completada pela criação de duas escolas (COSTA, 1981).

A Escola Central continuou a formar oficiais e a Escola Politécnica no Rio de Janeiro foi fundada em 1876 como primeira escola de engenharia civil completamente equipada do país. Uma outra escola deste porte foi feita em Minas Gerais, na cidade de Ouro Preto em 1876, e em São Paulo em 1893. Estes progressos refletiam, pois, os incentivos crescentes a favor da engenharia industrial (CARVALHO, 1978).

Em 1879, todavia, o Dr. Nuno de Andrade, reitor da escola de Medicina do Rio de Janeiro, realizou um ataque ferino às instalações da escola e este fato estimulou o governo a auxiliar no processo de desenvolvimento das escolas do país. Assim, sob a direção do Visconde de Sabóia, doutor em Medicina pela FMRJ em 1853 e Diretor da Faculdade de Medicina de 1881 a 1889, várias reformas foran realizadas, inclusive a construção de laboratórios de cirurgia dentária, que Sabóia se vangloriava em 1883, pois, ao seu ver, eles se equiparavam aos melhores da Europa (PETRUCELLI, 1997).

Há um aspecto interessante que merece ser comentado aqui: as mulheres, até 1879, eram proibidas de freqüentar as Faculdades de Medicina no Brasil, e em razão disso, formavam-se em outros países. Maria Augusta Generoso Estrela, nascida no Rio de Janeiro, não foi uma exceção, mas, ao tornar-se a primeira médica brasileira, seu exemplo contribuiu para a abertura das faculdades às jovens do nosso país (CAPUANO, 2002).

Desse modo, o decreto número 7.247, de 19 de abril de 1879, composto de vinte e nove artigos, finalmente abriria as portas das faculdades às mulheres brasileiras: Maria Augusta submeteu-se aos exames da FMRJ; a fim de validar seu diploma, conforme determinava a Reforma de 1832. Para tanto, apresentou a interessante tese Moléstias da pele (CALMON, 1967).

No ano de 1884, Rita Lobato Vello Lopes, gaúcha de São Pedro do Rio Grande, inscreveu-se no curso de medicina na FMRJ onde concluiu a primeira etapa do curso, com a transferência da família para a Bahia, sendo Rita a primeira mulher a inscrever-se na Faculdade de Medicina da Bahia, iniciando o segundo ano em maio de 1885. A Reforma Felipe Franco de Sá permitirá aos alunos a antecipação dos exames, e Rita, em outubro de 1887 , concluía os exames com notas máximas. O tema de sua tese 
é: Paralelo entre os métodos preconizados na operação cesariana. Em Pernambuco, a primeira mulher formada em medicina foi Maria Amélia Florentino Cavalcanti (SILVA, 1894).

Portanto, por volta de 1900, no Brasil, o número de instituições científicas, embora ainda pequeno, estava aumentando, e as instalações de várias delas tinham sido melhoradas. O número de cientistas estrangeiros que trabalhavam no Brasil, muitos dos quais contratados pelo governo, tinha crescido e isso estimulou um estudo da ciência mais desinteressado.

A preocupação com o saneamento e com a medicina estava crescendo particularmente no Estado de São Paulo, que era economicamente bem sucedido. Grandes nomes como Adolfo Lutz - médico e microbiologista - e Emílio Ribas sanitarista - começaram a ganhar importância. Estes cientistas estavam em contato com os padrões profissionais em suas áreas e, desse modo, publicavam trabalhos nas revistas européias e brasileiras. Logo, as oportunidades para as carreiras científicas estavam aumentando vagarosamente, em especial na medicina e na engenharia (ANTUNES, 1982).

Embora pareça curioso, apesar de todos esses estímulos, a ciência brasileira, em 1900, ainda se conformava ao padrão colonial: o meio científico era acanhado e nenhuma parte da estrutura educacional ou científica brasileira podia produzir ou treinar cientistas de pesquisa de forma sistemática. $\mathrm{Na}$ verdade, a originalidade na ciência era ainda resultado do esforço individual, bem como da educação européia e, muitas vezes, da fortuna pessoal. A falta de fundos para viajar à Europa a fim de melhorar a formação e aumentar os contatos com os que estavam na vanguarda da investigação científica foi também um impedimento. De maneira semelhante, as barreiras criadas pela língua portuguesa constituíram-se, por sua vez, como um empecilho. Assim, a institucionalização dos valores científicos estava longe de ser completa. Muitos problemas tiveram, portanto, que ser enfrentados antes que a tradição colonial pudesse começar a ser substituída por uma fase mais independente e produtiva da ciência (CAMPOS, 1941).

O fato de muitos países em desenvolvimento - tal como o Brasil nas últimas décadas do século XIX e nas primeiras décadas do século XX - estarem apenas começando a se industrializar, enquanto a industrialização na Europa e nos Estados Unidos entrava numa fase de organização e produtividade, ocasionou a dependência brasileira em relação à tecnologia estrangeira e, por sua vez, à ciência estrangeira. Este estado de dependência por síndrome do impacto só então se tornou um fator importante dificultando, por conseguinte, de forma significativa, a evolução para a autonomia científica. Para que se tenha idéia da situação, o sistema de educação característico do Brasil em 1900 preparava os homens para as carreiras de diplomata, político, jornalista e administrador, porém, não para a de cientista (BEN-DAVID, 1974).

A elite do Brasil tinha pouco interesse e pouca compreensão da ciência moderna. Qualquer progresso científico institucional teria que levar em consideração o fato de que a ciência ainda estava operando no vácuo e, para agravar o problema, sem qualquer apoio proveniente da educação.

Fatores muito mais enraizados, entretanto, também contribuíram para atravancar o progresso científico no Brasil. Em 1900, oitenta por cento da população ainda era completamente analfabeta. $\mathrm{Na}$ elite, para a qual a educação acima do nível primário estava disponível, muitos fazendeiros ricos não gostavam de mandar seus filhos para as escolas profissionais de leis e medicina, que ofereciam os únicos diplomas superiores no Brasil. A idéia de uma educação geral em artes liberais, provenientes da elite, teve que esperar o desenvolvimento de uma universidade em 1920. Como se vê, as 
relações entre a ciência e o governo era certamente outra área crítica: o apoio particular à ciência faltava no Brasil, portanto (DOMINGUES, 1995).

Desse modo, qualquer instituição científica teria que se voltar para os governos federal e estadual como únicas fontes de apoio disponíveis. $\mathrm{O}$ número total de instituições ainda era comparativamente pequeno e o seu papel era principalmente mais de transmitir conhecimentos obtidos fora do Brasil do que de encorajar investigação original. Obviamente, as instituições médicas, inclusive as escolas de medicina, os hospitais e as sociedades médicas, estão geralmente entre as primeiras instituições científicas a serem fundadas, uma vez que a necessidade de cuidados médicos sempre existe (FERREIRA, 1996).

Pode-se inferir, a partir de tudo o que até aqui foi comentado, que, enquanto profissão social, a prática da medicina é modelada pelos valores de uma sociedade e varia de país para país. A medicina pode ajustar-se, ainda, aos progressos, ao passo que a natureza aplicada à medicina, no Brasil, proporcionava oportunidades para a criação de laboratórios especializados e a contratação de investigadores, foi a urgente necessidade de fabricar soros e vacinas para a preservação e o combate a doenças, a mola propulsora da fundação dos primeiros estabelecimentos tanto em São Paulo, como no Rio de Janeiro (SANTOS FILHO, 1980). 


\section{AS DOENÇAS NO BRASIL: EPIDEMIAS}

Serão comentadas agora as epidemias que se alastraram pelo Brasil no período examinado. Vale salientar, inicialmente, que muitas das moléstias epidêmicas e nãoepidêmicas encontradas aqui já eram bem conhecidas dos europeus, doenças tais como a malária $^{1}$, varíola ${ }^{2}$ dessinteria, sarampo ${ }^{3}$ e tuberculose ${ }^{4}$. Outras, tais como as ulceras tropicais e a febre amarela era nova. A febre amarela foi particularmente importante para a história do Brasil visto que impulsionou na época a criação de institutos de pesquisas. O Tratado Único da Constituição Pestilencial de Pernambuco de João Ferreira da Rosa, médico letrado que clinicava em Olinda e Recife, descreveu esta epidemia - responsável pela morte de milhares de pessoas - no Nordeste do Brasil entre 1680 e 1694. A febre amarela não desapareceu do Brasil, mas ficou confinada a surtos locais. Voltou em proporções epidêmicas em 1849 e, depois disso, teve um efeito profundo, embora até agora inadequadamente avaliado, sobre a economia e a vida social do país.

Muitas doenças ocorreram e a primeira descrição publicada de uma epidemia a aparecer em qualquer parte foi editada em Lisboa por um brasileiro. O próprio diagnóstico era difícil, sendo a febre amarela muitas vezes confundida com a malária, de forma que as estatísticas médicas daquela época nem sempre fornecem um quadro digno de confiança da incidência da febre amarela. Os ataques da febre amarela, que eram curtos em duração e resultavam na morte ou na recuperação em cinco a sete dias, eram muitas vezes acompanhados na última fase da doença, pelo infame "vômitos negros". A taxa de mortalidade era alta, particularmente para os europeus, e a morte, muitas vezes, ocorria por meio de convulsões ou coma (GAMBETTA, 1987).

Algumas vezes, a doença parecia viajar longas distâncias sobre a água e aparecer quando os navios chegavam ao porto. Devido ao fato dos surtos de febre amarela ocorrerem, muitas vezes, com a chegada dos navios europeus dos climas frios, acreditava-se que o clima quente do Brasil fosse uma da causas da doença. O que não se compreendeu até 1900, entretanto, é o fato de ser a febre amarela transmitida de pessoa a pessoa através de um mosquito específico e, ainda, que o contato com a doença no período da infância proporcionava a imunidade. Desse modo, enquanto os nativos eram relativamente protegidos, os europeus que chegavam enfrentavam um alto risco de contrair a febre amarela (LIMA, 1901).

Assim, o principal estímulo ao estudo médico no Brasil foi, com certeza, o desejo de compreender as doenças e descobrir plantas com propriedades medicinais. Graças a esse intuito, muitos brasileiros e até mesmas pessoas que visitaram o país escreveram um certo número de livros que foram publicados em Portugal e na França. Porém, poucos médicos vieram ao Brasil para estudar a febre amarela de uma maneira sistemática, ou praticarem sua profissão, uma vez que fatores como a vastidão do interior, a escassez da população colonial e a sua dispersão, nada contribuíram para atrair os médicos. Por conseguinte, poucos médicos licenciados com diplomas universitários exerciam sua profissão na colônia.

A medicina e a farmácia eram, ostensivamente, regulamentadas pelo CirurgiãoGeral do exército. Na realidade, porém, os farmacêuticos locais, os curandeiros pela fé,

\footnotetext{
${ }^{1}$ Malária(084) Doença transmitida por Artrópodes . CID-10

${ }^{2}$ Varíola(050)Doença virais acompanhadas de exantema. CID-10

${ }^{3}$ Sarampo(055) Doença virais acompanhadas de exantema. CID-10

${ }^{4}$ Tuberculose(010-018) Doença infecto-contagiosa, causada por bacilo CID-10
} 
os ervanários e os fazendeiros cuidavam das necessidades médicas da população o melhor que podiam. No entanto, fora das cidades, não havia nenhuma organização de saúde particular ou pública e, em razão dessa carência, a maioria dos brasileiros vivia em condições de pobreza e doença. Esta situação de calamidade alterou-se apenas no século XIX, quando a organização profissional e a regulamentação da medicina no Brasil se iniciaram, garantindo uma forte tradição da medicina clínica em duas cidades: Rio de Janeiro e Bahia, mais especificamente, Salvador (EDLER, 1992).

Um fator prejudicial foi, sem dúvida, o alto padrão acadêmico exigido para entrar nas escolas; unido a isso, o fato de existirem apenas duas escolas no país até o começo do século XX, limitou drasticamente o número de médicos que se formava. Embora esse número fosse pequeno, os médicos brasileiros gozavam de um alto status social e estavam genuinamente preocupados com os padrões profissionais. Além disso, as revistas médicas, tais como Propagador das Ciências Médicas, publicadas por Sigaud (Jose Francisco Xavier Sigaud) e o Seminário de Saúde Pública, proporcionaram informações médicas aos interessados (SANTOS FILHO, 1991).

Quando as epidemias surgiam dentro e em volta do Rio de Janeiro, a sociedade e a Escola de Medicina enviavam seus membros e os alunos de medicina para as áreas epidêmicas a fim de estudarem a doença e tratarem dos doentes gratuitamente. Mesmo assim, a ignorância quanto às causas das doenças e os mecanismos de transmissão limitava significativamente o trabalho dos médicos. Desse modo, o tratamento de doenças, no Brasil, como em outras partes do mundo, baseava-se nos poucos remédios específicos testados pelo tempo, tais como a vacinação para a varíola, que foi introduzida no Rio de Janeiro e na Bahia. Assim, eram usados o Digitalis (planta medicinal utilizada para o tratamento de doenças do coração) quinino, muitas vezes em doses enormes, para a malária e as febres intermitentes, e compostos de mercúrio para as doenças venéreas. A sangria e o purgante eram também outro recurso habitual e tradicional. As especialidades farmacêuticas, desprezadas pelos médicos formados, eram largamente usadas, especialmente no interior, onde os médicos eram raros (DONATO, 2000).

Um sério problema foi, sem dúvida, a dificuldade de se conhecer a origem das doenças e, conseqüentemente, a incapacidade de se estabelecer os procedimentos necessários, como quarentenas e outras medidas sanitárias. Esse fato impediu, pois, que a maioria das leis sanitárias fosse eficaz durante as epidemias. Assim, fora das grandes cidades, a doença era generalizada, a medicina e a higiene eram muito simples, e os médicos licenciados eram consultados apenas nos casos extremos (LOBO, 1964)

Obviamente, o estrato social mais vulnerável às epidemias era, nesse período, os escravos. Muitas vezes mal alimentados, inadequadamente vestidos, seu trabalho era excessivamente duro. Não se esperava que vivessem muitos, e uma boa proporção da força de trabalho escravo estava sempre doente, sendo as doenças mais comuns o pulex penetrans bicho de pé , erisipela $^{6}$, tuberculose e diarréias ${ }^{7}$. Desse modo, quando os escravos ficavam doentes, eram tratados com remédios caseiros, ministrados pelo fazendeiro ou era chamado um curandeiro, que recorria a remédios de ervas e outras curas caseiras (CASTRO, 1979).

No que diz respeito à pesquisa médica, considerando a situação até aqui descrita, torna-se fácil compreender que, durante a maior parte do século XIX, essa pesquisa não fazia parte do trabalho do médico comum, como também não fazia parte do médico comum da Europa e dos Estados Unidos. As Escolas de Medicina da Bahia e

\footnotetext{
${ }^{5}$ Bicho de pé. Pulex penetrans, que causava ulceras no pé impedindo o trabalho.

${ }^{6}$ Erisipela: (035) Doena bacteriana. CID-10

${ }^{7}$ Diarréias: (006) Doença infecciosa intestinais. CID-10
} 
do Rio de Janeiro, por exemplo, eram as únicas fontes de cientistas médicas treinadas no Brasil e elas evidenciavam deficiência em relação ao ensino da medicina de laboratório. Observe na figura 2, a beleza da arquitetura da faculdade de medicina na Bahia. A fim de que se tenha uma noção, em 1901, uma nova lei criou a cadeira de microbiologia e 150 alunos eram ensinados, dispondo de apenas um único microscópio (DANTES, 1988).

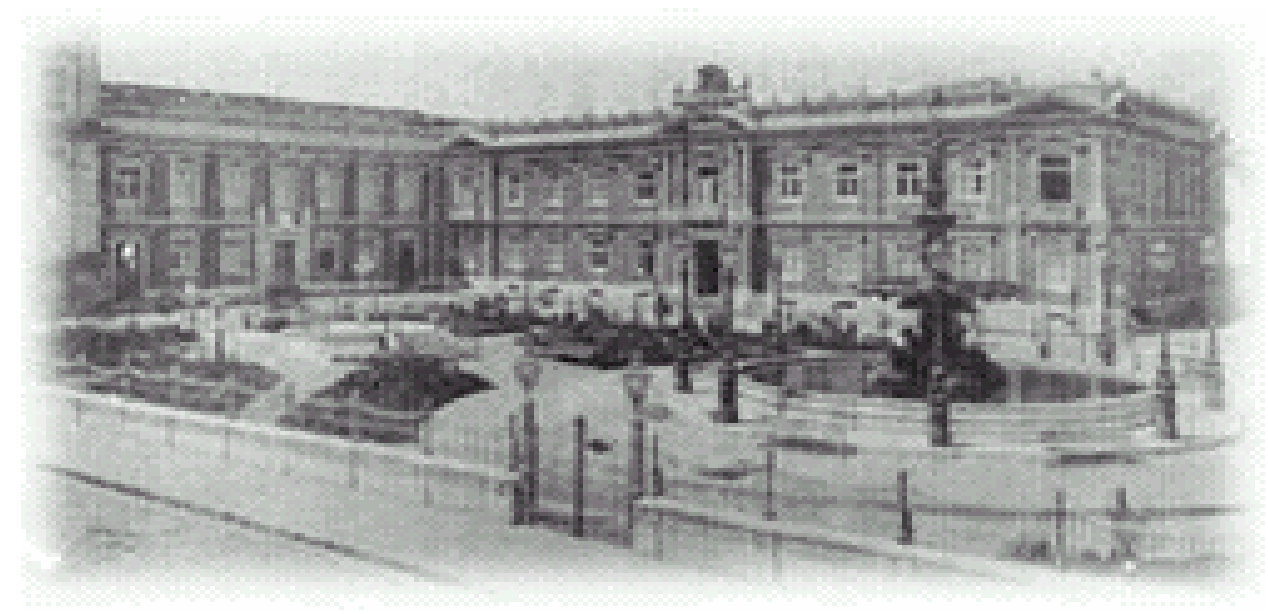

Figura 2 Faculdade de Medicina da Bahia

Disponível em: $<$ http://www.lepto.procc.fiocruz.br Acesso em 20 dezembro 2003

A situação da histologia e da patologia era bastante parecida. Estava claro que o enfoque do laboratório para a medicina, e até mesmo o uso do microscópio, não era parte rotineira do ensino médico no Brasil em 1900. O tradicionalismo da Escola de Medicina do Rio de Janeiro era tal que sugeria que qualquer progresso futuro da bacteriologia ou da patologia teria lugar fora da Escola de Medicina, em Instituições independentes orientadas para a pesquisa. Isto se deu, em especial, pelo menos, ser mais fácil encontrar soluções totalmente novas para os problemas da administração científica do que tentar reformar as instituições existentes (DANTES, 1980)

No entanto, os conhecimentos médicos foram, gradualmente, aumentando e demonstrando uma nova ênfase na pesquisa. Assim, apesar das limitações institucionais em relação à medicina experimental, havia alguns indícios, por volta de 1900, de que a situação da medicina e da saúde pública estava madura para ser melhorada.

A imigração para as cidades do Rio de Janeiro e São Paulo havia aumentado e a população urbana havia melhorado as condições sanitárias enquanto, ao mesmo tempo, eram introduzidas doenças, até então, ainda um tanto raras no país, tal como a cólera. A ameaça que as epidemias apresentavam para a valiosa força de trabalho era objeto de preocupação dos fazendeiros de café. Engenheiros e médicos elevaram-se a posições de importância, especialmente na cidade de São Paulo, que estava emergindo rapidamente como uma das cidades mais importantes e promissoras do Brasil. Além disso, novos movimentos intelectuais, tais como o Darwinismo e o Positivismo, exerceram uma influência indireta sobre a ciência, tornando o ambiente intelectual do Brasil mais propício às idéias científicas (FOUCAULT, 1980).

O Presidente Francisco Rodrigues Alves, eleito em 1902, havia feito campanha com o tema da necessidade da renovação da vida cultural, social e política do Brasil. 
Desse modo, o otimismo político deste ano coincidiu com o advento do interesse pelas ciências microbiológicas e a convicção crescente, entre os poucos intelectuais, de que a ciência podia vir em auxílio dos países em desenvolvimento na corrida do progresso.

Tradicionalmente, quando as expedições climatérias - estudos de geografia sobre o clima - das causas das doenças foram aceitas pelos médicos, o clima tropical do Brasil foi responsabilizado pelas doenças endêmicas ${ }^{8}$ epidêmicas ${ }^{9}$ do país. Presumiu-se também que a população do Brasil, racialmente miscigenada, era sensual e passiva, suscetível às doenças e incapaz do controle e da racionalidade individual ou coletiva para o progresso da civilização.

A crença de que o Brasil estava condenado a ficar para trás na corrida para o progresso havia sido reforçada. O fato de os estrangeiros que vinham para o Brasil não terem imunidade adquirida na infância pela exposição à febre amarela e serem, portanto, particularmente suscetíveis à doença, parecia apenas confirmar a validade da crença de que as populações racialmente misturadas do Brasil e o clima tropical os condenavam à doença e ao atraso.

Por meio da ciência, o Brasil podia escapar a um fatalismo histórico relativo à sua capacidade de alterar os acontecimentos, e a nação podia emergir como parte do mundo civilizado moderno.As doenças que assolaram o Brasil no início da colonização, não apresentavam os mesmos sintomas e perigos que em outros países e foi através da evolução da medicina brasileira que se efetuaram investigações e experimentos de inusitado interesse para o desenvolvimento da patologia brasileira (SANTOS FILHO, 1980)

Segundo uma pesquisa realizada acerca da história do Brasil, o processo de modernização começou após 1850, embora, em princípio, o ritmo da mudança fosse extremamente lento. Antes desta data, as inovações tecnológicas que haviam caracterizado a industrialização na Europa ainda não tinham se tornado parte da vida brasileira. Depois de 1850, o Brasil foi lançado decisivamente no turbilhão da economia internacional. Houve uma confiança aumentada no transporte moderno e na força do vapor e da eletricidade, um aumento da atividade comercial e industrial, e a emergência de novos grupos urbanos. A sociedade tradicional foi atacada lentamente. Em 1914, embora a promessa de modernização ainda não estivesse completa, novas expectativas haviam surgido quanto ao lugar da tecnologia, da indústria e da ciência no crescimento futuro do país (SCHWARTZMANN, 1979).

A urgente necessidade de fabricar soros e vacinas para a preservação e o combate às doenças foi a mola propulsora da fundação dos primeiros estabelecimentos, tanto em São Paulo, como no Rio de Janeiro. Data de 1888 o aparecimento do "Instituto Pasteur" do Rio de Janeiro, para o preparo da vacina contra a raiva. Augusto Ferreira dos Santos, lente de química da Faculdade do Rio de Janeiro, aprenderá a técnica necessária no Instituto Pasteur de Paris, enviado que fora pelo imperador D. Pedro II. A esse centro de vacinas, sucederam outros (SANTOS FILHO, 1980).

A implicação é que o Instituto Soroterápico, criado em 1893, com o objetivo de dedicar-se especialmente à microscopia e à bacteriologia em geral, com sua aplicação ao estudo das doenças endêmicas e epidêmicas, longe de ser um acontecimento único na história, com poucas conseqüências para o desenvolvimento posterior da ciência, agiram como um catalisador para a mudança. Não é surpreendente, que tenha sido o Estado de São Paulo, industrialmente adiantado, que tenha introduzido as técnicas mais avançadas para a época, sob a orientação de Adolfo Lutz (BENCHIMOL et al, 1993).

\footnotetext{
${ }^{8}$ Endêmica:Doença permanente em uma determinada região, em função de certas condições alimentação da população, como o bócio; as infecciosas, como a malária.

${ }^{9}$ Epidêmica: Doença que atinge ao mesmo tempo grande número de pessoas de uma região.
} 
$\mathrm{Na}$ década de 1890, os serviços sanitários do Estado tinham sido organizados segundo linhas modernas. Logo, nenhuma instituição podia se comparar ao Instituto Oswaldo Cruz no que se refere ao objetivo e à qualidade de seu trabalho. Em 1912, foi iniciada, finalmente, uma escola de medicina em São Paulo, cerca de 20 anos após a idéia ter sido discutida pela primeira vez. Valeu a pena ter esperado observe na figura 3, a beleza e a importante obra que foi realizada em São Paulo, com esta obra destinada para ser faculdade de medicina.

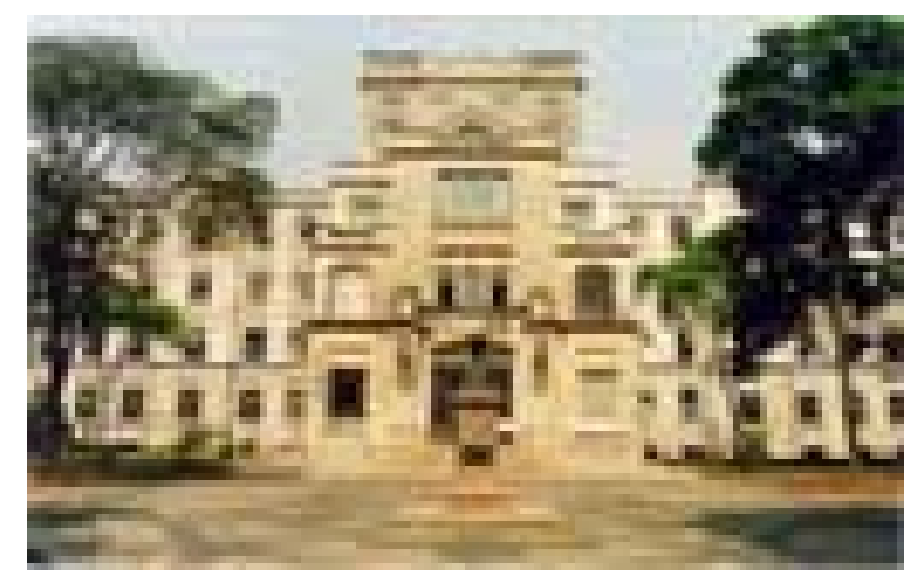

Figura 3 Faculdade de Medicina de São Paulo

Fonte Disponível em: http; //www.usp.Br/fm/sobre/histórico.php Acesso em 20 dezembro 2003

Um dos motivos para a ampliação dos programas federais de saneamento foi a ajuda da Fundação Rockeffeler. Em 1913, essa fundação havia organizado a sua Junta Internacional de Saúde para lançar programas de saneamento em todo mundo. Seus programas previam o reforço dos especialistas locais. A ajuda era oferecida apenas aos que a pediam, com a condição, de que o país donatário partilhasse os custos do programa e assumisse finalmente total responsabilidade se ele fosse bem sucedido (STEPAN, 1976).

O Instituto Soroterápico foi transformado em Instituto Butantan - um laboratório de produção soro antipestosos. O Butantan foi reconhecido como instituição autônoma em fevereiro de 1901, tornando-se, pois, internacionalmente reconhecido em 1914, entrando numa nova fase de produtividade. As conseqüências desse avanço foram a publicação da sua própria revista em 1918 e um novo programa de pesquisas e treinamento em áreas pouco conhecidas como o tétano e os antídotos para venenos de cobra e escorpião. Também se desencadeou um ataque científico à doença do café, broca do café, que estava devastando valiosas safras (FIGUEIRÔA, 1997).

Observe na figura 4, a fachada do Instituto Butantan, que foi criado na cidade de |São Paulo, como sendo o primeiro instituto do gênero. 


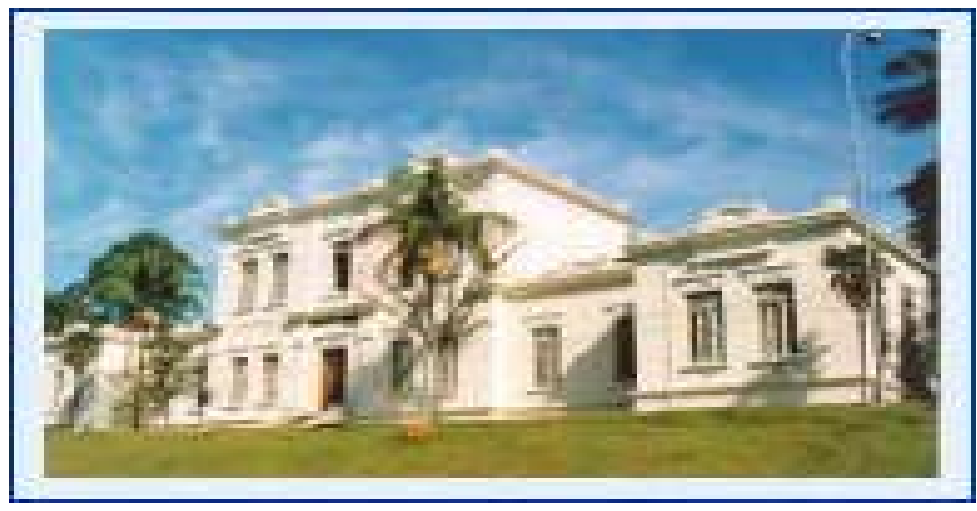

Figura 4 Instituto Butantan em São Paulo.

Fonte-Disponível em: $<$ http://www.butantan.gov.br Acesso em: 20 dez.2003 


\section{A CRIAÇÃo dOS INSTITUTOS DE PESQUISAS}

O "Instituto Municipal", instalado na fazenda de Manguinhos, com recursos proporcionados pela prefeitura do Distrito Federal, destina-se ao preparo de soro e vacina contra a peste bubônica que, em 1900 atingira, a antiga capital da república. Oswaldo Gonçalves Cruz - especializado em bacteriologia no Instituto Pasteur de Paris - foi um dos primeiros técnicos. No mesmo ano teve lugar a inauguração do "Instituto Soroterápico Federal" designação feita após a prefeitura doar o estabelecimento ao governo federal da República, com seus laboratórios e demais instalações, tudo muito rudimentar, sob a supervisão técnica de Oswaldo Cruz, que desempenhou também um importante papel no aumento do alcance dos serviços sanitários federais. Em 1902, com o nome de "Instituto de Manguinhos" este laboratório passou a ser chefiado, então, por um eminente sanitarista - Oswaldo Cruz. Logo, dentro de poucos anos, o modesto laboratório transformou-se no maior e melhor centro de patologia experimental do país, bem conhecido e respeitado no exterior (SANTOS FILHO, 1980).

Note na figura 5, que a cidade do Rio de Janeiro, ganhou com o Instituto de Manguinhos, também pela beleza da obra de engenharia.

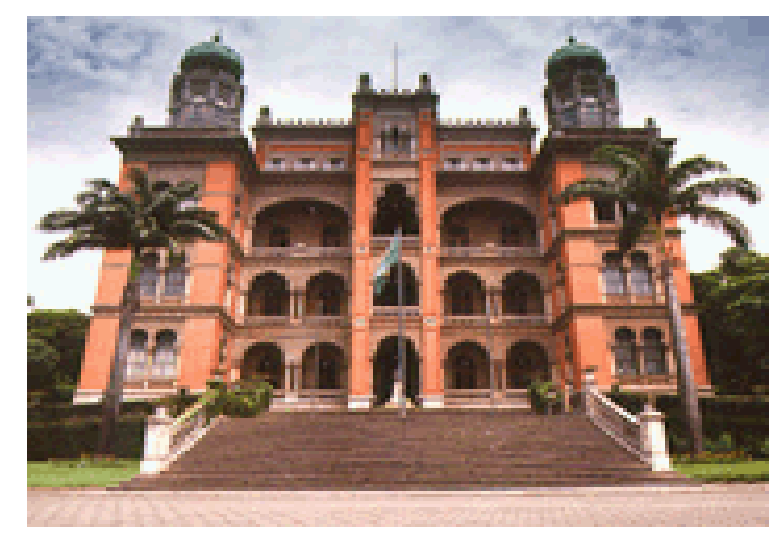

Figura 5 Instituto Manguinhos no Rio de Janeiro

Fonte-Disponível em: $<$ http://www.fiocruz.br Acesso em:20 dezembro 2003

Em 1918, Carlos Chagas foi encarregado de um programa federal contra a terrível epidemia de influenza (gripe espanhola) no Rio de Janeiro. Em 1919, sob a supervisão de Carlos Chagas, foram desencadeados os programas contra a ancilostomíase $^{10}$ e a febre amarela (FERNANDES, 1991).

Em 1927, o interesse pelos problemas agrícolas do Estado ocasionou a fundação do importante Instituto Biológico - apoiado pelo instituto Oswaldo Cruz destinado a pesquisas nas ciências agrícolas, da mesma forma que o Instituto Oswaldo Cruz realizava pesquisas relacionadas às ciências sanitárias.

A cooperação entre o Brasil e os Estados Unidos aumentou em 1928, quando a febre amarela voltou em proporções epidêmicas, devido ao relaxamento da vigilância

\footnotetext{
${ }^{10}$ Ancilostomiase: Doença comum no Brasil é a ancilostomose, popularmente conhecida por Amarelão.
} 
contra o mosquito, e o surgimento, da febre amarela silvestre, transmitida por uma espécie de mosquito (A gambiae) diferente do Aedes aegypti. Então, um certo número de técnicos e cientistas trabalharam em contato íntimo com os americanos, surgindo, em conseqüência, uma nova geração de cientistas sanitários no Brasil. Alguns pesquisadores do Instituto Oswaldo Cruz também foram mandados aos Estados Unidos e à Europa para treinamento avançado financiado pela Fundação Rockefeller (ROSEN, 1994).

A capacidade do governo brasileiro em tirar proveito da ajuda técnica estrangeira, neste período, pode ser considerada, pelo menos em parte, mais como função da existência de um centro adequado de ciências sanitárias na forma do Instituto Oswaldo Cruz, do que, simplesmente, como uma forma de dependência à ajuda do exterior. Em seus primeiros anos, o Instituto foi pioneiro no ensino da microbiologia para estudantes de medicina. À medida que as universidades eram fundadas no Brasil, primeiro no Rio de Janeiro, em 1920 e, mais significativamente, em São Paulo (considerada a primeira universidade moderna), em 1934, o ensino da biologia foi assumido pela universidade. Esta separação do Instituto Oswaldo Cruz de uma estrutura universitária resultou em diminuição de suas tarefas de pesquisa e ligou sua equipe mais intimamente às ciências aplicadas. Desse modo, a solidariedade prematura de seu esforço de pesquisa e sua concentração em uma área especializada da ciência, proporcionou relativo sucesso ao Instituto, que começou a criar um certo grau de endogamia $^{11}$ e fossilização ${ }^{12}$ (ALMEIDA, 1998).

À direção de Carlos Chagas segue-se a direção de outros membros da equipe original, tais como Henrique Aragão e Cardoso, sugerindo um apoio exagerado em um pequeno grupo dentro do Instituto. A autonomia financeira do Instituto foi prejudicada no regime de Getúlio Vargas, quando a reorganização levou à interrupção da venda e do uso de suas vacinas e soros com lucro, e à subordinação ao Ministério da Saúde. O Instituto sofreu com a intervenção política durante o regime de Vargas nas décadas de 1930 e 1940. Vale salientar que, à medida que outros campos da ciência e da tecnologia disputaram o auxílio do governo, todo campo da saúde passou por um declínio em sua posição de importância em relação a outras áreas; isto também prejudicou, conseqüentemente, o Instituto Oswaldo Cruz (ALVES, 1989).

Apesar destes retrospectos, a tradição da pesquisa biomédica estabelecida, no Instituto, durante quase 35 anos - de 1900 a 1934 -, sob a direção de Oswaldo Cruz e Carlos Chagas foi responsável, em grande parte, pelo fato de até hoje a pesquisa biomédica se caracterizar com um dos campos mais fortes da ciência no Brasil.

$\mathrm{Na}$ cidade de São Paulo, a febre amarela não era o problema mais premente, uma vez que a alta altitude da cidade impedia que o mosquito Aedes aegypti se reproduzisse, infectando, portanto, a população. A doença era epidêmica no porto de Santos e nas pequenas cidades que serviam às plantações de café, tais como Sorocaba e Ribeirão Preto. Era preciso mão-de-obra para a lavoura e os imigrantes começaram a trabalhar nas lavouras do café no interior, com isso a febre amarela veio também para o interior do Estado.Com o café no âmago da economia estadual, a questão da febre amarela figurava com importância nas atividades do departamento estadual de saúde pública (GARCIA et al, 1980)

Não só a febre amarela, a peste e a varíola eram grandes assassinas, mas também o sarampo, a escarlatina, a tuberculose e as doenças intestinais menos dramáticas, mas sempre presentes, cobravam seu tributo anual em vidas humanas.O

\footnotetext{
${ }^{11}$ Endogamia: leva um aumento da homozidade, com conseqüente queda de heterozigosidade.

12 Fossilização: é uma acidente, resultado da infiltração de sais minerais nas células que compõem os tecidos, transformando-os em pedra.
} 
anúncio da nomeação de Oswaldo Cruz como diretor do Departamento Federal de Saúde Pública, em março de 1903, desagradou a muitos porque, na época, ele era jovem, desconhecido e quase sem experiência administrativa. Muitos duvidavam de que alguém cuja carreira profissional tivesse sido inteiramente confinada à estreita arena de laboratórios científicos possuísse as habilidades políticas e administrativas necessárias (LEMOS, 1954).

A campanha de saúde pública tornou-se uma desculpa para muitos grupos diferentes que se opunham ao Presidente Rodrigues Alves, tentarem desacreditar o governo. Foram feitas obras de saneamento e embelezamento no Rio de Janeiro e muitas famílias tiveram seus cortiços desocupados e houve, então, a conseqüente mudança para os morros (favelas). O Serviço Sanitário investia contra as epidemias (cólera, peste bulbônica, varíola e febre amarela) quando o sanitarista Oswaldo Cruz decreta a vacina obrigatória, a população pobre aproveita a ocasião para realizar passeatas, comícios contra o governo, saques de lojas e depredações de bondes e carroças. Era a Revolta da Vacina - o povo punha para fora toda a revolta acumulada contra o governo - políticos e militares tentaram depor Rodrigues Alves, mas não conseguiram. Note na figura 6 , o método de aplicação da vacina na população, que a figura deixa visível o medo. A Igreja Positivista do Rio de Janeiro opunha-se à vacinação sob o fundamento de que ela limitava a liberdade sob estes fundamentos (SEVCENKO, 1985)

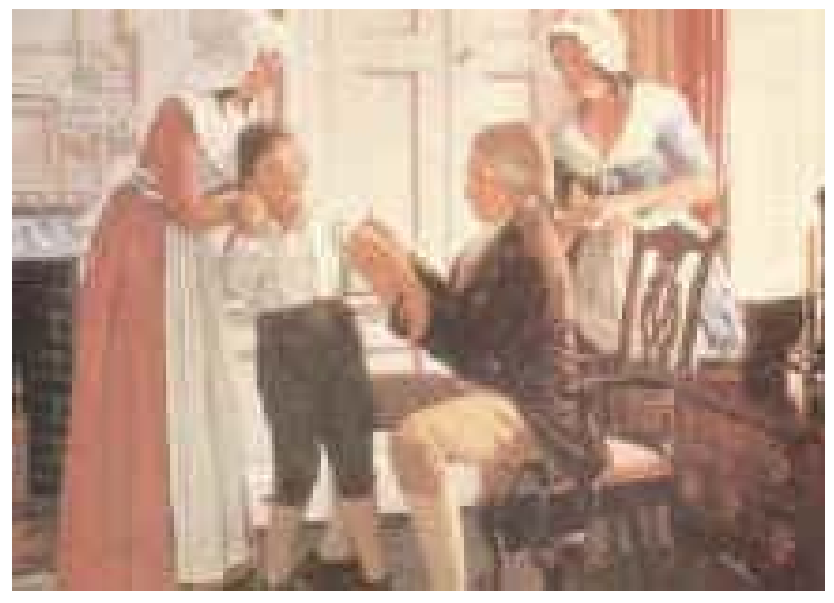

Figura 6 Aplicação da vacina

Fonte-Disponível em: $<$ http://www.coc.fiocruz.br Acesso em: 20 dez.2003

Os militares positivistas opunham-se especialmente sob estes fundamentos e, por motivos políticos complexos, estavam decididos a criar problema para o governo, afinal, muito comerciante não gostavam, por exemplo, da perturbação dos negócios causada pela limpeza e alargamento das ruas. O próprio Oswaldo Cruz tornou-se alvo de sátiras nas piadas dos jornais, que publicavam caricaturas dele como um monstro a impor as técnicas cruéis da ciência a uma população acovardada.

O público resistia à entrada dos inspetores sanitários porque não se tinha certeza do objetivo de sua ação, porque estava alienado ao governo e tinha medo do que poderia acontecer.A resistência à vacinação compulsória foi tão grande que a parte da legislação que a regulara foi separada da lei principal em 1903. A vacinação compulsória tornou-se lei, finalmente, em outubro de 1904(MEIHY et al, 1990). 
Apesar de tudo, a lei deixou de ser posta em vigor e grande parte da população do Rio de Janeiro permaneceu sem a vacinação.Note na figura 7, um dos laboratórios da época que produziam a vacina. Em 1908, a cidade sofreu as conseqüências, ao ser vítima de um dos piores surtos de varíola da sua história: mais de nove mil pessoas morreram, em razão dessa doença, naquele ano. Em 1909, não houve, entretanto nenhum óbito.

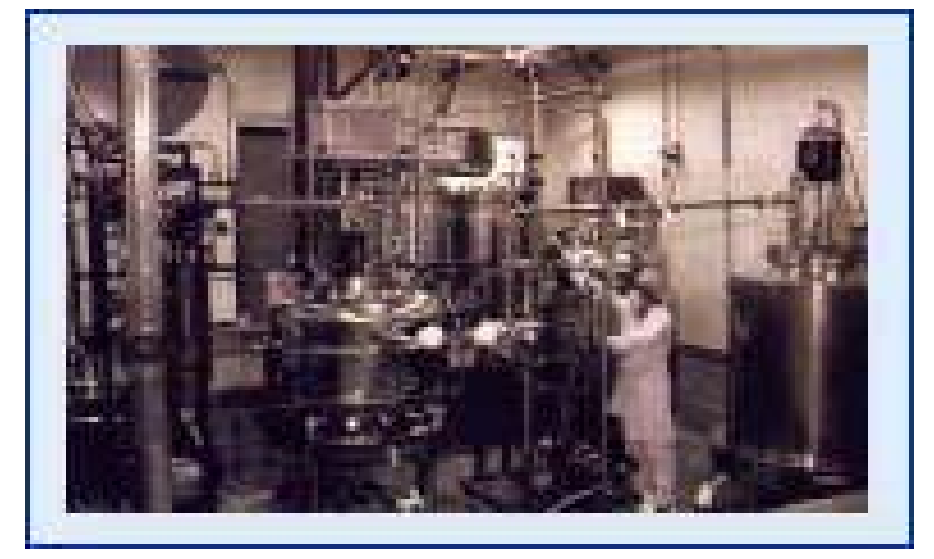

Figura 7 Produção da vacina.

Fonte-Disponível em: $<$ http:www.coc.fiocruz.br Acesso em: 20 dez.2003

A importância da campanha para a história da ciência foi, entre outras, elevar Oswaldo Cruz de uma posição de relativa obscuridade ao primeiro plano no cenário nacional. Foi a primeira vez na história do Brasil que um cientista profissional tornarase largamente conhecida do público no Rio de Janeiro e exterior.

$\mathrm{O}$ assunto da ciência mereceu grande destaque através dos jornais do Rio de Janeiro e, no curto espaço de três anos, mais pessoas tinham sido expostas às idéias e técnicas da medicina científica do que em toda história anterior do Brasil. Por conseguinte, internacionalmente, a confiança no Brasil estava também aumentando. Os prédios em ruínas, onde funcionavam os antigos laboratórios, estavam em processo de substituição por laboratórios modernos. Oswaldo Cruz desejava, assim, um centro para o estudo das doenças infecciosas e tropicais segundo as linhas do Instituto Pasteur, em Paris.

O novo Instituto, de acordo com Oswaldo Cruz, deveria ser incumbido do ensino da bacteriologia, da fabricação de vacinas e soros, e de pesquisa original. No entanto, o pedido de Oswaldo Cruz para transformar o Instituto Manguinhos, criado em 1901, em uma instituição de ensino não foi incluído na legislação enviada ao Congresso para debate. O plano de Oswaldo Cruz de criar um centro independente de medicina experimental que realizasse pesquisas no campo da microbiologia e fabricasse vacinas e soros não saiu, da mesma forma, tão bem. Quase todas as propostas foram vetadas. Nem autonomias financeiras e administrativas foram concedidas. Essas decisões, porém, não o detiveram.

Chegaram noticias à cidade que em Manguinhos estava sendo praticado um novo tipo de ciência; não era, portanto, muito surpreendente que novas pessoas, sobretudo os curiosos e os interessados, fossem atraídas para lá. Uma verdadeira romaria de alunos e professores foi conferir as atividades realizadas no instituto: todos muito ansiosos para começar o trabalho. Quando, finalmente, os novos prédios ficaram 
prontos, eles abrigavam alguns dos mais eficientes laboratórios médicos da América do Sul. Arquitetonicamente um tanto bizarro, apesar de imponentes, os prédios ficavam numa colina, dominando a larga planície que separava Manguinhos da cidade, bem como da Baía de Guanabara (BENCHIMOL, 1993)

Em 1906, a campanha da febre amarela tinha sido um sucesso comprovado e a praga foi erradicada. Oswaldo Cruz, no auge de seu prestígio político, tornou-se um herói nacional, personificando, para muitos, o triunfo da verdade sobre a ignorância, da ciência sobre a superstição. O cientista apresentou, outra vez, ao Congresso, o pedido legal de um Instituto "Pasteur" no Brasil. Agora, depois do sucesso da campanha de saneamento, o Congresso não recusou o pedido: surgiu, assim, o nome do Instituto de Patologia Experimental de Manguinhos e seu orçamento foi triplicado.

O Instituto foi separado do Departamento de saúde pública e organizado como Instituição Científica independente sob o Ministério da Justiça Interior. A organização ganhou independência financeira e foi autorizada não só a preparar vacinas e soros, como também a estudar as doenças infecciosas e parasitárias, a criar uma escola veterinária e a organizar comissões científicas de inquérito. Foi permitida, ainda, uma publicação científica intitulada Memórias do Instituto Oswaldo Cruz. Atribuiu-se ao Instituto o direito de oferecer contratos a cientistas para trabalhar em sua equipe, e a própria equipe foi dividida em seis departamentos (LOPES, 1997).

A aprovação do Decreto de 12 de Dezembro de 1907 representou uma vitória pessoal de Oswaldo Cruz e um passo importante no progresso da ciência no Brasil. Neste ano, o Brasil foi convidado a participar da XII Conferência Internacional de Higiene, a ser realizada em Berlin; faz-se interessante salientar que o Brasil foi o único país da América Latina convidado. Por suas contribuições ao progresso das ciências da higiene, os juízes, em Berlin, concederam ao Instituto de Patologia Experimental de Manguinhos, seu maior prêmio: a medalha de ouro (STEPAN, 1976).

A organização Oswaldo Cruz ajudou, ainda, na década de 1920, a levar a efeito uma colaboração eventual entre o governo brasileiro e a Fundação Rockefeller, a fim de erradicar algumas das principais doenças endêmicas e epidêmicas do Brasil, tais como a febre amarela e a ancilostomíase (amarelão ou opilação).

Portanto, em suas pesquisas - doenças de Chagas, epidemia de gripe em 1918, brocas do café, entre tantas outras, a barreira entre a ciência básica e aplicada se romperam; muitas investigações realizadas originalmente, por seu valor científico, produziram resultados práticos inesperados, ao passo que estudos práticos levaram, muitas vezes, a novas pesquisas. Houve, em conseqüência, uma realimentação contínua e benéfica de ambas as extremidades do espectro da "pesquisa e desenvolvimento". A febre amarela forneceu outra área de concentração. O fato desta se caracterizar mais como uma doença virótica do que bacteriológica, não era conhecido na época (SANTOS FILHO, 1980).

As atividades e descobertas da área de protozoologia - um dos mais importantes campos de indagação científica - foram tão grandes que é possível falar de uma escola na América do Sul. Esta escola foi iniciada por Aragão e Chagas, constituindo-se o primeiro campo da ciência a atrair cientistas estrangeiros para o Instituto, tais como Prowazewk e Max Hartmann.

$\mathrm{O}$ maior estímulo à protozoologia ${ }^{13}$ veio naturalmente quando Carlos Chagas descobriu a doença do sono americana (trypanosomiasis americana). Esta descoberta foi um excelente exemplo de pesquisa biológica resultando, em uma descoberta de

\footnotetext{
${ }^{13}$ Protozoologia: entendida como o estudo dos agentes e das doenças causadas por protozoários patogênicos para o homem, nos seus vários aspectos básicos, diagnósticos, imunológicos, patogênicos, terapêuticos e epidemiológicos.
} 
importância prática. A descoberta, anunciada na Alemanha e no Brasil, deu início a anos de pesquisas no Instituto, resultando que o "Mal de Chagas" transformou-se numa das mais estudadas de todas as doenças humanas. Em conseqüência desta descoberta, Carlos Chagas recebeu, em 1913, o Prêmio Schaudinn de protozoologia. O agente causador da doença, o Tripanosoma Cruzi - nome dado por Chagas em homenagem ao seu amigo e colega Oswaldo Cruz - foi estudado intensivamente. Em conseqüência do interesse nas doenças envolvendo insetos transmissores, deu-se o desenvolvimento da entomologia no Instituto sob a orientação de Adolfo Lutz (SCHWARTZMANN, 1979).

Um país em desenvolvimento geralmente é tolhido em suas pesquisas pelo pequeno número total de cientistas, mas esta desvantagem pode ser parcialmente superada se, em vez de tentar cobrir várias áreas diferentes de pesquisa, o país concentrar os seus esforços em algumas áreas específicas.

Para o Instituto Oswaldo Cruz, era uma vantagem não haver nenhuma outra instituição no Brasil competindo com ele pelos cientistas. Isso se deve ao fato de que, na época da fundação do Instituto Oswaldo Cruz, não existia nenhuma política nacional para a ciência, e a pesquisa médica não podia, então, esperar o apoio automático do governo.

Em seu trabalho, desenvolveu-se mais auto referencialmente do que com referência exclusiva à ciência européia ou norte-americana, e permitiu aos cientistas brasileiros se tornarem mais exportadores de idéias científicas do que apenas importadores. Logo, a pesquisa no Instituto desenvolveu um caráter distintamente nacional ou brasileiro. Infere-se disso, que as ciências médicas permitem aos países em desenvolvimento realizar um bom trabalho, mesmo quando o apoio para a pesquisa básica é pequeno (STEPAN, 1976).

A pesquisa proporcionou, pois, flexibilidade ao Instituto para reagir a novas crises de saúde pública e iniciar novas áreas de pesquisa. Através da publicação em revistas de pesquisas, os cientistas brasileiros estabeleceram contatos com o exterior. $\mathrm{O}$ reconhecimento internacional conquistado pelo Instituto melhorou, por sua vez, a posição da organização no Brasil e encorajou o apoio do governo, que passou a impedir a migração dos cientistas brasileiros - estes, sem qualquer garantia de sua carreira de pesquisa no Brasil, podiam sentir-se tentados a seguir suas carreiras no exterior (STEPAN, 1976).

Oswaldo Cruz, padecendo de problemas renais, ficava cada vez mais incapacitado pela doença desde 1908, e havia preparado os colegas para a sua aposentadoria ou morte (na verdade, ele se aposentou alguns meses antes de sua morte, em 1917). Carlos Chagas assumiu o Instituto de Manguinhos e, após dois anos na direção, dobrou o orçamento do Instituto e criou vários novos departamentos. Com o progresso, veio a mudança da medicina puramente clínica para a medicina de laboratório, e a fundação concederam, um certo número de laboratórios para cientistas de pesquisas e especialistas.

O que havia de mais parecido com o Instituto Oswaldo Cruz no que diz respeito as suas funções, era o Instituto Bacteriológico, que vivia sob a direção de um parasitologista, protozoologista e entomologista: Adolfo Lutz.

O Instituto Adolfo Lutz foi fundado em 1892, numa ocasião em que o Estado de São Paulo estava experimentando um rápido crescimento econômico e populacional, e surgiram novos apoios à ciência, à engenharia e, conseqüentemente, verificava-se um certo grau de profissionalização da ciência. Este também foi um período de mudança institucional, quando foram criados novos centros de ensino, tal como a Escola Politécnica, inaugurada em 1892 (SINGER, 1968). 
O Instituto Bacteriológico desempenhou um papel importante, modelando o desenvolvimento de novo programa de saúde pública no Estado ali pela década de 1890 e começo da década de 1900, quando São Paulo tornou-se, neste campo, um dos Estados líderes da Federação.

A história do Instituto é, portanto, muito importante, pois acrescenta ao nosso conhecimento um período importante de um Estado importante. No entanto, o Instituto Bacteriológico não cresceu o suficiente para garantir a sua sobrevivência. Seu trabalho de pesquisa foi apenas o de um cientista. O trabalho de ciência aplicada no Instituto também começou a falhar quando, exasperado pelas dificuldades administrativas, Adolfo Lutz o abandonou para entrar na equipe do Instituto Oswaldo Cruz (FERRI et al, 1979). Como podemos observar na figura 8 , a importância da abra pela sua fachada, o Instituto Adolfo Lutz.

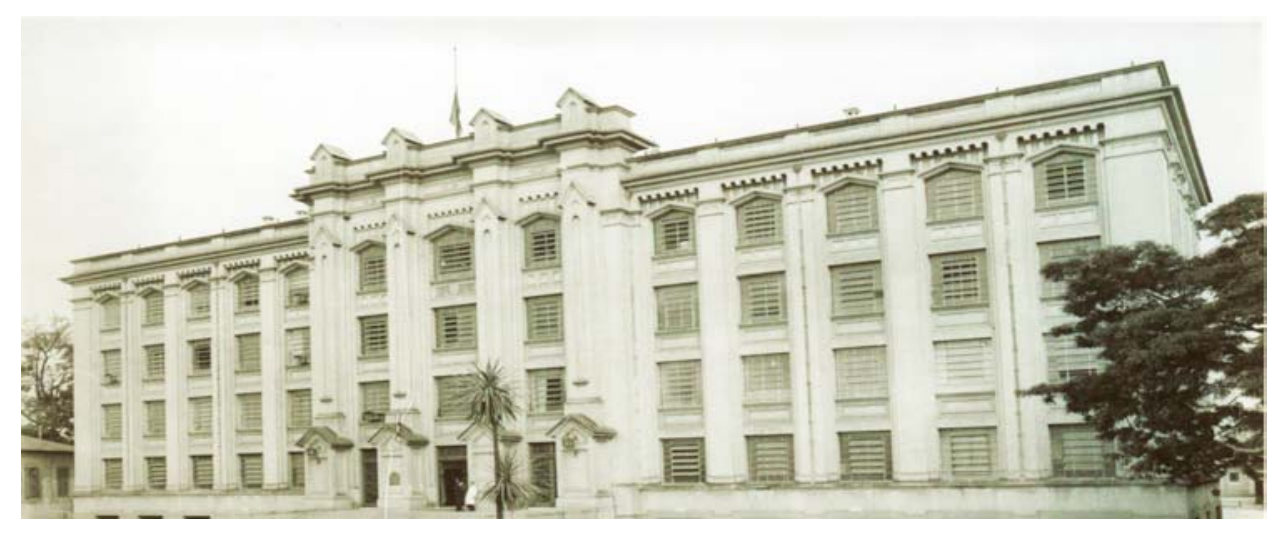

Figura 8 Instituto Bacteriológico Adolfo Lutz em São Paulo

Fonte-Disponível em:<http://www.ial.sp.gov.br Acesso em 20 dezembro 2003

A medicina brasileira era principalmente clínica e sanitária até 1900, com descentralização política, empréstimos culturais e urgências políticas que a ciência brasileira entraria no século XX.

Aqui se encerram as razões do início do desenvolvimento científico no Brasil caracterizado como sendo a vacina o tema predominante em ciências e tecnologia abordando os primórdios da bioengenharia no Brasil, sua continuação se dá na instrumentação que é considerada a continuidade da bioengenharia no Brasil. 


\section{ENGENHARIA BIOMÉDICA}

Sua origem na engenharia, nascendo da evolução da indústria médicohospitalar, odontológica e farmacêutica, é elevada à condição de especialidade pelo esforço de abnegados engenheiros que acreditaram na importância de sua atuação no setor, na formação de um mercado para os produtos de alta tecnologia, bem como, no potencial dos métodos da engenharia para a criação de soluções, tanto para a medicina como, numa visão mais ampla, para todas as bio-ciências.

A solução dos problemas da biologia - ciência que estuda os seres vivos e suas relações, a fim de conhecer as leis peculiares à matéria viva - e medicina - arte e ciência de curar e prevenir doenças - reside nos conhecimentos de engenharia, matemática, computação e física e, através desta multidisciplinaridade é possível definir a engenharia biomédica.

Esta multidisciplinaridade, incorporada recentemente, tem prestado substancial contribuição às ciências biomédicas e à tecnologia aplicada a problemas médicos. Na sua definição mais ampla, a engenharia biomédica tem pontos de tangência com outras áreas multidisciplinares do conhecimento, tais como físiosologia, biomatemática e informática médica.

Através dessa definição, percebe-se que a engenharia biomédica é uma área muito vasta e que hoje é impossível um único indivíduo cobrir toda a gama de conhecimentos desta ciência.

Pode-se dividir a engenharia biomédica em quatro sub-áreas: Engenharia de Reabilitação, Engenharia Médica, Engenharia Clínica ou Hospitalar e Bioengenharia.

\subsection{ENGENHARIA DE REABILITAÇÃO}

Pode-se definir esta engenharia como a aplicação de métodos da engenharia arte de aplicar os conhecimentos científicos à invenção, aperfeiçoamento ou utilização da técnica industrial em todas as suas determinações - e das ciências exatas - as que somente admitem princípios, conseqüências e fatos rigorosamente demonstráveis - no projeto e construção de sistemas, equipamentos e dispositivos para processamento de sinais biológicos, estimulação neuro-muscular, sustentação, locomoção, fisioterapia e próteses artificiais utilizados para recuperação ou minimização dos efeitos de deficiências neurológicas e músculo-esqueléticas, estando contida no âmbito da engenharia biomédica como uma de suas subdivisões.

A engenharia de reabilitação é uma das mais recentes especialidades da engenharia biomédica e se concentra basicamente na pesquisa e produção de equipamentos e próteses, atuando na indústria ou, de forma multidisciplinar, junto à unidade de terapia e instituições de pesquisa. Os recentes avanços conquistados no campo do processamento de sinais biológicos e neuro-transmissores constituem uma das áreas de maior desenvolvimento nesse setor e vem criando novas perspectivas para atuação da medicina na criação de terapias mais eficazes.

Em associação com novas gerações de materiais e novas concepções de fabricação, ampliaram-se as possibilidades para construção de próteses inteligentes comandadas por sinais mio-elétricos para as mais variadas finalidades, agora mais leves, mais confortáveis e com custo acessível.

O conhecimento preciso da biomecânica da estrutura esquelética e os efeitos causados pelos esforços sobre a estrutura alveolar dos ossos - adquiridos em simulações calculadas por métodos avançados como o de elementos finitos, por exemplo - inaugura 
novas gerações de próteses, tanto externas como implantáveis, muito mais resistentes, duráveis e seguras.

\subsection{INFORMÁTICA MÉDICA}

Refere-se à aplicação dos métodos da engenharia e das ciências exatas no projeto, construção, operação, e manutenção de equipamentos informatizados e programas especialmente desenvolvidos para as diversas áreas que compõem o setor da saúde.

Focaliza o estudo da informática e da informatização com o objetivo de pesquisar e desenvolver aplicações específicas nos campos da medicina, da odontologia, veterinária, farmácia, bioquímica e outras que compõe o setor da saúde.

A informática é aplicada na administração hospitalar, no diagnóstico não invasivo através de imagens, no controle e monitoramento de equipamentos cirúrgicos e de terapia, no controle de servo-mecanismos de próteses externas e implantáveis, na pesquisa, na educação virtual e na comunicação digital remota.

Como as atividades no ramo da informática são extensivas, compreendem desde a criação de software para administração de consultórios até o estudo de moléculas em microscópios digitais. Essas atividades podem ser altamente complexas quando envolvem, por exemplo, a simulação digital de redes neurais em supercomputadores ou sensoriamento remoto de guias de precisão em cirurgias cerebrais.

Sendo um dos ramos que mais tem se desenvolvido, apoiado fortemente tanto pela iniciativa privada como pelos órgãos governamentais em todo o mundo, o seu potencial de aplicação na área da saúde é incalculável, face ao próprio desenvolvimento acelerado do setor como um todo.

\subsection{ENGENHARIA CLÍNICA OU HOSPITALAR}

A engenharia clínica ou hospitalar tem como objetivo principal criar e manter a infra-estrutura necessária para a correta e ininterrupta operação de todos os sistemas implantados com a eficiente utilização dos insumos disponíveis. Esta ciência estabelece planos logísticos de suprimentos, rotinas de inserção, rotinas de manutenção preditiva e corretiva, políticas de racionalização e economia, métodos de treinamento de pessoal técnico, normas internas de segurança e higiene no trabalho, aferição da qualidade e produtividade, metas de produção, planejamento de custos e orçamento.

A esta engenharia compete, ainda, projetar e fiscalizar a construção de instalações prediais, mecânicas e elétricas; proceder à inspeção, avaliação e perícia das instalações clínicas e hospitalares de seus acessórios e equipamentos, quando, no âmbito da sua graduação específica, exercer a atividade profissional conforme estabelecido pelo CONFEA - Conselho Federal Engenharia, Arquitetura e Agronomia.

A crescente complexidade da tecnologia e das estruturas hospitalares para atendimento em larga escala, vem exigindo cada vez mais a presença de um corpo de engenharia no hospital. Além desse campo diretamente ligado à estrutura hospitalar, o engenheiro clínico poderá atuar em uma das muitas intersecções com outras áreas da engenharia e das bio-ciências, como na pesquisa e desenvolvimento de equipamentos 
médicos, odontológicos, hospitalares, de próteses, de biomateriais, na certificação de qualidade de produtos, ou em consultoria, entre outros.

\subsection{BIOENGENHARIA}

Esta ciência refere-se à aplicação das técnicas e métodos da engenharia e das ciências exatas no desenvolvimento de órgãos internos artificiais e dispositivos auxiliares dos sistemas biológicos, estando contida no âmbito da engenharia biomédica como uma de suas subdivisões. Nascendo do esforço pioneiro dos médicos durante a fase inicial da era dos transplantes cardíacos que, médicos habituados a criar ferramentas e equipamentos para suas necessidades urgentes, encontraram as dificuldades técnicas inerentes ao gerenciamneto de estruturas industriais produtivas, necessárias naquele momento, e também para o projeto de desenvolviemnto de equipamentos de monitoração e de suporte da vida com alto nível de complexidade e de confiabilidade, competências que iam além dos domínios da Medicina.

A bioengenharia focaliza o estudo do sistema orgânico à luz da matemática, física e bioquímica, entre outras, equacionando sua constituição e funcionamento sistêmico com o objetivo de criar ferramentas teóricas que permitam compreender e criar artificialmente órgãos internos, equipamentos extracorpóreos e próteses implantáveis. Um movimento de aproximação efetivo entre a medicina e engenharia, resulta na criação de centros de bioengenharia diretamente ligadas às instituições hospitalares.

Apesar de já contar com mais de cinqüenta anos, a bioengenharia apenas começa a se desenvolver, graças ao desafio constante de superar a extraordinária complexidade envolvida no funcionamento dos organismos vivos. Ela vem sendo trabalhada e utilizada em todo o mundo, em setores cujo desenvolvimento é considerado mais urgente e menos sujeito às limitações de ordem técnica ou material, como as áreas cardio-respiratórias, a ortopedia de tecidos artificiais e de materiais biocompativéis.

Atuando em uma nova área do conhecimento, o profissional se verá, quase sempre, diante de situações inusitadas e absolutamente novas, que exigirão conhecimento profundo e técnico e uma grande capacidade criativa na solução de problemas. Essa característica faz da bioengenharia uma das mais excitantes carreiras técnicas, uma vez que o engenheiro pode exercer, de fato, todo o potencial para o qual foi treinado.

Constitui-se, assim, a bioengenharia, como um campo de atuação complexo, eminentemente multidisciplinar e que exige uma crescente colaboração entre especialistas das mais diversas áreas, cujo relacionamento nem sempre é fácil e, certamente, requer a renúncia às vaidades profissionais em benefício da ciência, além de total dedicação, sendo, pois, considerada, por muitos, um verdadeiro sacerdócio.

Diretamente envolvido com questões éticas e morais na aplicação de suas conquistas perante a sociedade, o bioengenheiro vive com o conflito, e na visão de alguns, não deve esperar reconhecimento por suas descobertas e criações. A história, infelizmente, nos mostra um passado de trabalho solitário e quase anônimo.

Suas atividades se estendem por uma série de especializações e uma vasta gama de pesquisas embrionárias desenvolvidas em centros especializados e empresas privadas espalhados pelo mundo, entre as quais se destacam: bioengenharia cardiovascular, circulação extracorpórea assistida, estimulação interna artificial, órgãos artificias, engenharia celular e tecido artificiais, próteses biomecânicas e engenharia do sistema respiratório. 
Se prende a dois aspectos fundamentais, o primeiro com respeito à compreensão do relacionamento entre os sistemas que compõem os organismos vivos, que produzem substâncias transmissoras de informações e se comunicam quimicamente por mecanismos ainda não devidamente esclarecidos. O segundo com relação ao custo das pesquisas direcionadas, que exigem recursos humanos, materiais e financeiros, se impondo como um fator limitante ao avanço em determinadas áreas. 


\section{COMO SURGE A BIOENGENHARIA NA PERSPECTIVA DOS ENTREVISTADOS}

O perfil histórico da Engenharia Biomédica/ Bioengenharia no Brasil, além de uma análise contemporânea dos mais variados temas da especialidade, as opiniões que se seguem nos dão uma mostra de como a Engenharia Biomédica/Bioengenharia evoluiu no país e como ela vem se tornando um diferencial na qualidade da prestação de serviços de saúde para todo o mundo.

$\mathrm{O}$ que nos dias atuais se entende como Bioengenharia está muito ligado ao desenvolvimento da Instrumentação e, em particular, à instrumentação médica, cujo desenvolvimento é necessário a interação de médicos e engenheiros, nestes incluídos físicos, químicos, matemáticos e cientistas da computação. Surge então outros campos ligados à Bioengenharia, como Bioinformática, genômica, etc*14

Em 1950, um grupo de professores, se reuniu na reitoria da Universidade de São Paulo para fundar o IBECC - Instituto Brasileiro de Educação, Ciência e Cultura com a finalidade específica de catalisar, através de educação formal ou da educação extra-escolar, a melhoria do ensino das ciências experimentais. O ponto de partida foi que a ciência experimental se aprende realizando alguma experimentação inteligente e não só através da abstração, a partir de bons livros-texto. ${ }^{15}$

A trajetória percorrida pelo IBECC foi das mais árduas e nem sempre a mais certa, mas procurou-se não desanimar e alcançar alguns progressos. O mecanismo de auto-sustentação do IBECC, tendo como base a produção e venda de material para laboratório de ensino, mostrou-se de difícil concretização. Somente a partir de 1962, o IBECC resolveu importar tecnologia para acelerar a renovação do ensino de Ciências, aproveitando a onda de novos currículos que então surgiram nos Estados Unidos subsidiados pela National Science Foundation. São traduzios textos, introduzidos materiais de laboratório, adquiridos filmes e instituídos cursos, com a vinda de professores experintes dos Estados Unidos principalmente. Em 1962 vieram o físico Uri Huber Schaim, Aaron Lemonick, Philip Morrison e Dario Moreno (Chile), para lecionar o PSSC (Physical Science Study Curriculum). Da mesma forma, para Quimica (cursos CBA e CHEMS) e Biologia (curso BSCS) foram instituídos cursos. Posteriormente, vieram os cursos de Introdução a Fisica (IPS), de Geociências (ESCP) e do projeto Harvard de Física. Também em Matemática ocorreu tradução do conjunto de livros do SMSG e a seguir foi ministrado treinamento em alguns cursos. ${ }^{* 16}$

Em 1963 é instituído, com verba da UNESCO - Organização das Nações Unidas para a Educação a Ciência e a Cultura, o projeto internacional do Ensino Programado para Óptica, com a elaboração de Nahum Joel (Chile), Paar Berval (Suécia), Le Xuan (Coréia) e Paulus Aulus Pompeia (Brasil), vieram professores de diversas partes da América latina e após 18 meses de trabalho, produziram-se textos de instrução programada de Óptica, loops, ensino pela televisão de $16 \mathrm{~mm}$, em branco e preto, com versões sonoras em português e espanhol.*17

Em 1967, dadas às dificuldades crescentes do IBECC para atender, dentro das limitações que seu sistema de organização impunha, a produção de materiais cada vez mais complexos, foi instituída a FUNBEC - Fundação Brasileira para o

\footnotetext{
$14 /{ }^{15} /{ }^{16}$ TEIXEIRA, A. de S. 1983. Antonio de Souza Teixeira. Prof. Dr. Fundação Valeparaibana de Ensino. Revista Educação Brasileira. Ano V n.11. Brasília.
}

$17 / 18 / 19 / 20 / 21$ TEIXEIRA, A. de S. 1983. Antonio de Souza Teixeira. Prof. Dr. Fundação Valeparaibana de Ensino. Ano V. n.11.Brasília. 
Desenvolvimento do Ensino de Ciências - para a qual adotou mecanismo de auto manutenção com base na produção de outro tipo de material, menos sazonal e mais independente das alternâncias do potencial de compra do poder público; deveria existir uma razão mais clara para a entrada de uma Fundação em nova atividade industrial e a opção recaiu finalmente na instrumentação de eletrônica médica e de óptica, porque o IBECC já havia então tentado uma incursão nessas duas áreas, a partir de protótipos executados com base em ajuda financeira da FAPESP - Fundação de Amparo à Pesquisa do Estado de São Paulo.*18

A bioengenharia no Brasil nasceu com a criação da FUNBEC, em 1969, deu-se início à produção de eletrocardiógrafos e nos anos seguintes se completou toda uma família de instrumentos de eletrônica para cardiologia, com desfibriladores, cardioconversores, bicicletas e esteiras para ergometria, monitores, ecocardiografos, fonocardiografos. O faturamento cresceu, o numero de servidores aumentou, montou-se um sistema de vendas e de assistência técnica com filiais e representações. ${ }^{19}$

$\mathrm{Na}$ linha de instrumentos de Óptica as coisas não cresceram do mesmo modo, devido à natureza semi-artesanal de alguns procedimentos e à falta de infra-estrutura de apoio, não existindo praticamente pessoal para a execução de grande parte das tarefas necessárias. Apesar de tudo, chegou-se à produção de microscópios para Ensino de $1^{0} \mathrm{e}$ $2^{0}$ Graus, microscópio de plástico para Ensino Extra Escolar ou recreação, lunetas e atendimento a todo o tipo de usuário - da Industria ou da Faculdade. ${ }^{20}$

A importância na produção de instrumentos seja no controle de medida, de diagnostico médico ou de análise laboratorial, é sempre um sistema que recebe de algum modo um sinal externo, leva-o até um transdutor que termina por algo como mover um ponteiro ou efetuar registro digital, após processo de amplificação do sinal, acabando por fornecer uma medida, registrar um procedimento ou tornar de algum modo conhecida a variável que se quer detectar. ${ }^{21}$

Ao optar pelo desenvolvimento de instrumentos no Brasil, sem optar pelo processo clássico de pagamento de direito por transferência de tecnologia, a FUNBEC Fundação Brasileira para o Desenvolvimento do Ensino de Ciências assumiu encargos financeiros muito pesados, necessitando contratar pessoal especializado que evidentemente acabou adquirindo maior capacidade de enfrentar problemas novos, pelo desafio diário que passou a enfrentar, abandonando a posição conformada de copiar receitas sem necessidade de buscar soluções, que já vinham indicadas na compra dos "pacotes". Ao adotar esta atitude, a FUNBEC passou a dar emprego a grande numero de profissionais de todos os níveis, diferentemente do que ocorre com as empresas multinacionais e com os importadores que passam receitas e "caixas pretas" para a produção, executando cegamente o que foi ditado no exterior, muitas vezes sem ou com pouca necessidade de pessoal de nível superior e conseqüentemente desnecessidade de contratar engenheiros, físicos, etc instalando todo um processo muito eficiente para transferir dólares para o exterior, dar empregos aos países desenvolvidos, manter o subdesenvolvimento do receptor da tecnologia transferida e aumentar o grau de dependência dos países importadores. $*^{22}$

Desta maneira são gerados os grandes problemas com o hemisfério Sul se transformando num buraco de dividas e o hemisfério Norte adquirindo um 
desenvolvimento galopante, com povos com 10.000 dólares per capita ou mais, enquanto que o Terceiro Mundo vegeta com uma centena de dólares ou menos per capita, ocorrendo alguns casos, como Brasil, Argentina, México e outros, com 1.500 a 2.000 dólares per capita e uma divida externa que tende para os 1.000 dólares per capita, gerando desemprego, recessão, sacrifícios para pagamentos de juros etc*. ${ }^{23}$

Independentemente, porém, da substituição de importações, a geração de instrumentos no País tem um efeito educativo multiplicador muito grande, completando a formação escolar do engenheiro ou do físico, transformando-o suficientemente criativo para a montagem de novas indústrias, oferecendo mais empregos, etc. Ocorre também que muitos destes profissionais passam a dar cursos na Universidade, voltando com novas idéias e tornando o ambiente muito mais realista, ao interagir com o mundo industrial. Uma industria criativa não pode ficar na dependencia de ideias importadas. Reciprocamente, a universidade criativa depende essencialmente da existência de empresas criativas para onde encaminhar seus formandos e, em alguns casos, recebê-los de volta com novas idéias. Nisto, a indústria de instrumentos pode ter e realmente tem papel fundamental. ${ }^{24}$

Para levar a termo, na FUNBEC, o protótipo de ultra-som Bidimensional, tiveram que efetuar reduções junto ao laboratório de microeletrônica da Escola Politécnica, gravar em vidro no laboratório do INPE - Instituto Nacional de Pesquisas Espaciais, em Cachoeira Paulista, e resolver toda uma série de problemas que a simples importação da sonda de ultra-som nos teria evitado, mas que haveria também tolhido a geração de um potencial de conhecimentos e a interação, tão importante, com o sistema nacional de Pesquisa e Desenvolvimento.*25

Há que temperar a vontade de cada um para polarizar grande número de pessoas e gerar alguma tecnologia nacional. A polarização de muitas pessoas para objetivos comuns é que faz a grandeza tecnológica dos povos e ajuda a criar o orgulho nacional. O importador de "caixas pretas" nada significa para o País e pouco ou nada traz em termos de progresso; ao contrário, cria o hábito de ser usuário e não gerador de idéias e aí se institui a dependência tecnológica e sua utilização subserviente e telecomandada. ${ }^{26}$

Isto deve ser entendido, dentro de uma época de exaltação nacionalista, na qual se adotava o modelo de substituição de importações, como as então CACEX - Carteira de Comércio Exterior e SEI - Serviço Exportação Internacional vigiando as compras externas de componentes indispensáveis, etc. "Contratamos, na FUNBEC, engenheiros e técnicos, constituímos os setores de Engenharia de Projetos, do Produto, de Processos e da Produção e estávamos todos envolvidos em algo que hoje se classifica como Bioengenharia" $* 27$

Na cidade do Rio de Janeiro no ano de 1963, o físico Alberto Luiz Coimbra, reuniu um grupo de pesquisa na Universidade Federal do Rio de Janeiro e deu inicio em pesquisas e desenvolvimentos ligados a física aplicada àmedicina. Este grupo era independente da Universidade, e esta pesquisa desenvolvida com o passar dos anos foi agrupando outros departamentos da universidade. ${ }^{28}$

Essa evolução histórica criou um dos mais importantes núcleos de pesquisas aplicadas em bioengenharia para a medicina, sendo que em 1971 surge a COPPE -

${ }^{26} / 27 p^{28} / 29$ INFANTOSI, A. F. C. 2001. Antonio Fernando Catelli Infantosi. Prof. PhD. Universidade Federal do Rio de Janeiro. Entrevista Concedida Ana Maria Antonio.17 de junho. 
Comissão de Pós-Graduação e Pesquisas em Engenharia, mantendo um departamento em separado da universidade. $O$ que existia em termos de Engenharia biomédica/bioengenharia, tanto no Brasil quanto no resto do mundo, era fundamentalmente instrumentação biomédica e processamento de sinais biológicos, quase não se falava em imagem. No caso de processamento de sinais, estes em geral tinham como fonte o sistema cardio-vascular e a instrumentação era também voltada para a cardiologia, tanto suportando as atividades clínicas quanto às cirúrgicas. Obviamente outros sinais de outros órgãos eram também processados, tais como o eletromiograma e eletroencefalograma. ${ }^{29}$

O programa de engenharia biomédica conscientizou-se que o "gargalo tecnológico" não estava no equipamento em si, mas no transdutor, ou seja, naquele elemento que se colocava em contato com a fonte geradora e que permitia que se captasse a informação sobre o órgão em questão. Aí se deu uma mudança significativa, no Brasil como um todo e também no exterior, em que o enfoque deixou de ser o equipamento em si para ser "o bloco do equipamento" que era a interface entre a eletrônica propriamente dita e o corpo humano. Isso no que se refere à instrumentação. No processamento, novas técnicas de análises foram desenvolvidas e a visão de sistema, e não somente o órgão, tornou-se cada vez mais relevante, em particular voltada para o controle biológico. ${ }^{* 30}$

Criado o primeiro curso de pós-graduação do país nesta área e somente voltado para a formação de mestres, do lançamento do primeiro congresso nacional da especialidade, em 1973 e 1974, durante o $3^{0}$ Congresso a, SBEB - Sociedade Brasileira de Engenharia Biomédica foi oficializada, tendo como fundadores um grupo ainda pequeno constituído pelos mestrados do PEB - COPPE Programa de Engenharia Biomédica e profissionais vinculados ao Instituto do Coração - USP, em 1975.*31

Desde então, a SBEB - Sociedade Brasileira de Engenharia Biomédica - tem participado da evolução da Engenharia Biomédica/Bioengenharia no país. Atualmente, a Sociedade tem buscado divulgar a área, facilitar a troca de experiências entre os especialistas, promovendo, assim, sua atualização científica e profissional. Para isso, além da realização de simpósios e do Congresso Brasileiro, a cada dois anos, edita a RBEB - Revista Brasileira de Engenharia Biomédica, que alcançou prestigio nacional e internacional com suas edições anuais. Hoje, a revista é distribuída para todas as sociedades cientificas de Engenharia Biomédica/ Bioengenharia dos países da América brasileiras de apoio à pesquisa e ao ensino, tais como a CAPES e o CNPq* ${ }^{32}$

Ao longo dos anos, outros grupos se constituíram, alguns vinculados à pósgraduação em Engenharia Elétrica, tais como a UNICAMP, USP e a UFSC, outros como programas de Engenharia Biomédica/Bioengenharia isoladamente como a UFPB Universidade Federal de Paraíba. O doutorado só surgiu na COPPE anos depois, na década de 80. Recentemente, cursos de mestrado em Engenharia Biomédica/Bioengenharia foram criados em universidades privadas, como em Mogi das Cruzes e São José dos Campos, ambas em São Paulo. Vale salientar que a graduação em Engenharia Biomédica/Bioengenharia é uma opção muito questionável, pois o profissional desta especialidade deve ter uma formação abrangente e multifacetada. Uma vez que a tecnologia cumpre papel fundamental na formação desse profissional e, enfatizando o fato de que a tecnologia evolui com enorme rapidez, o conhecimento das

$30 / 31 / 32 / 33$ INFANTOSI, A. F. C. 2001. Antonio Fernando Catelli Infantosi, Prof. PhD. Universidade Federal do Rio de Janeiro. Entrevista concedida Ana Maria Antonio. 17 de junho 
ciências básicas é, fundamental, ou então o profissional pode ficar desatualizado em curto espaço de tempo.*33

O que, por um lado, historicamente, se justifica, hoje em dia, já não deveria ser mais porque a Engenharia Biomédica/Bioengenharia não utiliza somente conceitos da Engenharia Elétrica. Utiliza-se também das outras engenharias, por exemplo, da Mecânica. Então, o que acaba acontecendo é que, às vezes, até mesmo o fato de um grupo de Engenharia Biomédica/Bioengenharia estar inserido dentro do departamento sobre a inter e multidisciplinaridade da Engenharia Biomédica/Bioengenharia, pode ser um fator limitante. Isso pode acarretar uma inibição na criação de linhas de pesquisa com menor ênfase. Enfim, essa situação, às vezes, resulta na não criação de uma nova linha por se estar umbilicalmente ligada a um departamento de Engenharia Elétrica. Ou então, em uma mesma universidade trabalhando em separado, quando eles deveriam estar trabalhando em conjunto.*34

Os equipamentos, em particular os digitais, foram cada vez mais incorporados à rotina das unidades de atendimento à saúde, em especial às hospitalares. E isso gerou, inicialmente, uma nova necessidade: o gerenciamento dos equipamentos. Até então, o gestor destas unidades era profissional da área médica. A incorporação da tecnologia cada vez mais sofisticada e em maior número se, por um lado, contribui para a melhoria da qualidade do atendimento à saúde, poderia aumentar, em contrapartida, os custos deste atendimento. Logo, tornou-se necessário formar equipes constituídas de especialistas na gestão desta tecnologia; surge, então, a Engenharia Clínica. ${ }^{35}$

No Brasil e demais países, o impacto das novas tecnologias hospitalares, bem como a revolução tecnológica da década de 80 , mostrou a importância de se formar tais profissionais. Desta forma, a atuação do profissional da Eng. Biomédica/Bioengenharia passa a se dar também dentro do sistema de saúde, no qual ele passa a ser consultado tanto sobre a aquisição do equipamento quanto em relação ao seu uso mais adequado. A Engenharia Clínica surge, por conseguinte, como uma conseqüência da incorporação da tecnologia no atendimento à saúde, e o profissional que exerce esta função é um engenheiro biomédico com atuação neste ramo. ${ }^{* 36}$

Hoje, a Engenharia Clínica e a avaliação tecnológica são, do ponto de vista de diminuição de custos e também da melhoria da qualidade de serviço, uma necessidade. Assim, é possível ter um serviço de qualidade, a um custo menor, se a tecnologia for adequadamente incorporada e utilizada.

Como o atendimento à saúde no Brasil é parcialmente público e o sistema é, para a maioria da população, coberto pela previdência, o atendimento está deixando a desejar também porque falta um melhor gerenciamento da tecnologia envolvida nesse processo. Tomar decisões com relação à aquisição de tecnologia, contratos de manutenção, metodologia de acompanhamento de equipamentos e uso adequado, exige que se tenha profissional preparado para tal. A Engenharia Clínica e a Avaliação de Tecnologia em Saúde são as áreas da Engenharia Biomédica/Bioengenharia que cumprem esse papel fundamental.*37

Quanto à graduação específica em Engenharia Biomédica/Bioengenharia, Infantosi acha complicado. Vários foram os países que tentaram. Em boa parte deles, isso não foi em frente. Está certo que foi há uma década. Pode-se criar, mas para tornar

\footnotetext{
34 p35/ INFANTOSI, A. F. C. 2001. Antonio Fernando Catelli Infantosi. Prof. PhD.Universidade Federal do Rio de Janeiro. Entrevista concedida Ana Maria Antonio, 17 de junho.

$36 /{ }^{37} /{ }^{38}$ INFANTOSI, A. F. C. 2001. Antonio Fernando Catelli Infantosi. Prof. PhD. Universidade Federal do Rio de Janeiro. Entrevista concedida Ana Maria Antonio. 17 de junho.
} 
esse tipo de decisão, as pessoas têm que estar muito cientes do perfil do profissional que querem formar. E, obviamente, ao mercado de trabalho que esse profissional vai ter que se adequar. Obviamente, os mestres, doutores e mesmo os especialistas que se formam em Eng. Biomédica/Bioengenharia tem atuado na própria área de Eng. Biomédica/Bioengenharia. E, como esses profissionais têm uma formação bastante abrangente, podem atuar em outras áreas que não a Engenharia Biomédica/Bioengenharia. Para Infantosi "considero ser muito difícil formar um profissional deste tipo e com uma capacidade de visão crítica numa área tão extensa como a Eng. Biomédica/Bioengenharia em termos de graduação".

Em relação às industrias e à tecnologia computacional, não só o Brasil, como a maioria dos países em desenvolvimento, estão, neste setor, muito aquém do desejado. $\mathrm{O}$ problema não é a capacidade, mas é ser economicamente viável. Para Infantosi "Alguém diria: olha seria fundamental que existisse eletrocardiógrafos em todos os postos de saúde do Brasil. Seria fundamental, sim. Mas quem vai comprar isso? É o Estado? Ele vai comprar um eletrocardiógrafo para cada posto de saúde? Não. Então a indústria vai fabricar para quem? Para exportar?*38

Infantosi analisa: "Sendo o eletrocardiógrafo um dos equipamentos mais básicos, inclusive está completando 100 anos. Não estou falando de um equipamento de ultra-som obstétrico que também deveria ser acessível mesmo nos pontos mais remotos do país. A necessidade do equipamento existe. Só que quem tem que investir na aquisição de equipamentos é o Estado. Ou seja, a indústria teria que fabricar para o Estado que seria o principal consumidor e não as clinicas e os hospitais privados. Se o Estado não tem uma política voltada para isso, aquilo que a indústria produzir vai ser aquém da sua real capacidade e pode se tornar economicamente inviável."

$\mathrm{O}$ retorno pode se dar, talvez, de forma mais rápida, caso o custo baixe sensivelmente. O problema é que em tudo isso fica claro o seguinte: quando se quis fazer uma política voltada para a siderurgia, se criou a Siderbrás. Quando se quis uma política voltada para a produção de energia, criou-se a Eletrobras, para o petróleo, a Petrobrás. Ou uma política voltada para a área nuclear, se criou a Nuclebrás. A população não tem a Saudebrás. Então não tem um esforço concentrado e voltado objetivamente para atender a saúde como um todo e de uma forma coerente, onde os diversos componentes deste sistema possam produzir de uma forma integrada com um único objetivo. Então, se a população não tem isso, também não se tem financiamento. E este é um dos problemas que a população enfrenta. Não é criar uma nova estatal, mas criar uma visão integrada. E essa visão integrada, infelizmente não existe seja por parte das secretarias de saúde, estaduais e municipais, e nem do Ministério da Saúde (INFANTOSI, 2001).

A predominância dos grupos de Engenharia Biomédica/Bioengenharia no país, historicamente, e em particular, a cardiologia, é uma doença mais urbana. De acordo com Infantosi "Lógico que ela representa um enorme impacto social. Dados informam que a classificação de óbitos do Ministério da Saúde, é lógico que elas (as cardiopatias) ocupam um lugar destacado. Mas é uma questão histórica ... Quando se iniciou a Engenharia Biomédica/Bioengenharia ela era muito mais voltada para a área de cardiologia. Hoje já se encontra um grande número de profissionais em linhas de pesquisa da bioengenharia: fisiologia pulmonar, neurologia, ginecologia, obstetrícia e até mesmo a parte mais clinica, mais laboratorial para a utilização de determinadas tecnologias, determinados métodos, que facilitem a obtenção de resultados de exames laboratoriais. Isso já está mais próximo da realidade, das necessidades da realidade"(INFANTOSI, 2001). 
A população ainda não tem conhecimento dos benefícios da bioengenharia, SABBATINI explica que "Não há do que ter medo. As técnicas que começaram a ser utilizadas nos seres humanos já passaram por diversos testes e foram aprovadas e mostraram ser seguras e efetivas. É importante saber que o artificial não tem rejeição pelo corpo humano, diferente do orgânico que o nosso próprio organismo ataca".

Diversas pesquisas e não apenas próteses e implantes que estão sendo pesquisados. Apesar de ainda em etapa de testes, existem chips que auxiliarão na redução da dor e que serão eficazes para quem possui doenças hoje ainda sem cura.

A diversidade em uma universidade com variedade de interesses, a pesquisa toma diferentes formas. A ciência é a pesquisa cujo propósito imediato é gerar mais conhecimento. Ela abrange problemas de origem acadêmica ou prática. E desenvolvimento é a pesquisa que quer chegar, rapidamente, a um produto ou processo de interesse comercial ou social.

A instrumentação é o trabalho investigativo destinado a produzir equipamento que, embora sem valor comercial, é necessário para apoio à própria pesquisa. 


\section{PRODUÇÃO E APLICAÇÕES DA BIOENGENHARIA NO BRASIL}

\subsection{MAPEAMENTO DA BIOENGENHARIA NO BRASIL}

Este levantamento dos núcleos que desenvolvem a engenharia biomédica/bioengenharia no Brasil foi aproveitado da Sociedade Brasileira de Engenharia Biomédica - SBEB e conseguimos concluir que no Brasil os núcleos de pesquisas chegam ao número de vinte e seis unidades em diferentes estados do Brasil, a visualização dos Estados de Pernambuco, Santa Catarina, Minas Gerais, Rio Grande do Sul, Paraná, Rio de Janeiro, Paraíba, São Paulo.

O nome do grupo de pesquisa, o tipo de curso que oferece: Graduação, PósGraduação em nível de Mestrado e Doutorado, o ano de início do grupo e finalmente a linha de pesquisa que ele desenvolve voltado para as pesquisas em bioengenharia.

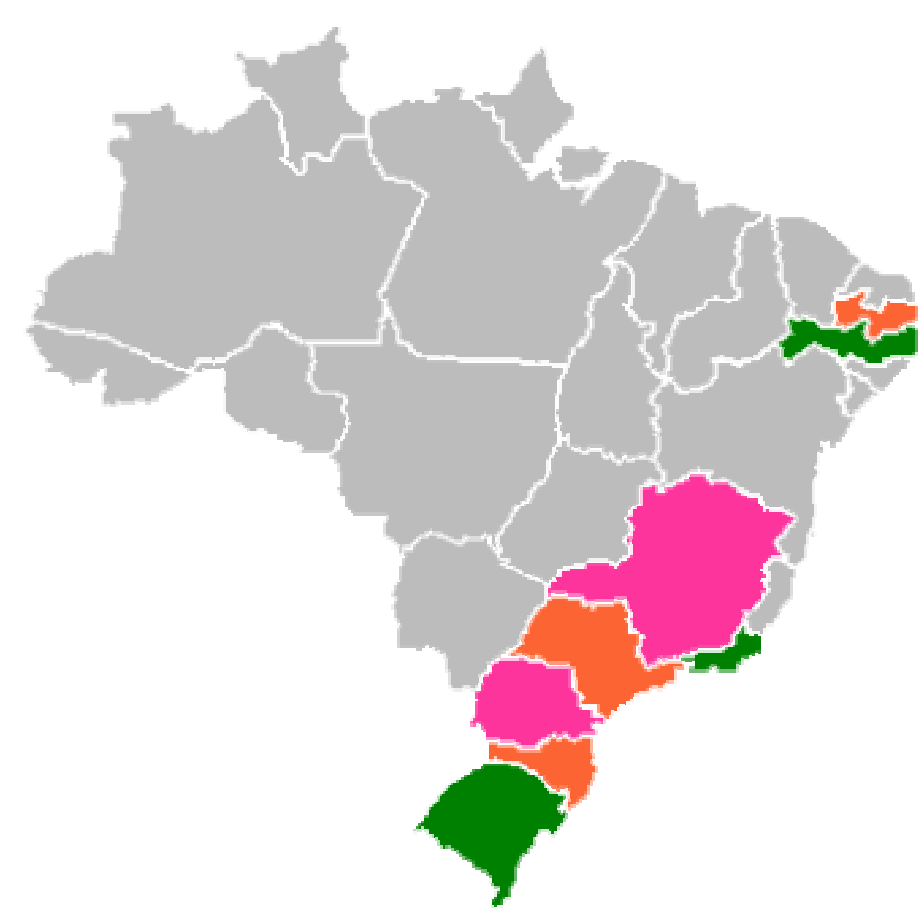

Figura 9 - Mapa do BRASIL, evidenciando os estados que desenvolvem bioengenharia.

Fonte-Disponível em: $<$ http://www.sbeb.org.br Acesso em: 20 dez.2003 


\section{PERNAMBUCO}

\section{UFPE- BIOFÍSICA}

Localizado: Universidade Federal de Pernambuco, cidade Recife.

CCB - Centro Ciências Biológicas

Oferece curso em nível de graduação em Engenharia Biomédica

Ano de inicio - 2002

Linhas de Pesquisas: Análise de Sinais, Ressonância Magnética e Laser, Dispositivos e Sensores, Tecnologia Nuclear.

\section{SANTA CATARINA}

\section{GPEB/UFSC}

Localizado: Universidade Federal de Santa Catarina, Florianópolis.

IEB - Instituto de Engenharia Biomédica

Oferece curso em nível de graduação e Pós-graduação, Mestrado e Doutorado.

Ano de inicio - 1980

Linhas de Pesquisas: Instrumentação Biomédica, Engenharia Clinica,

Informática Medica.

\section{MINAS GERAIS}

\section{GEB/EFEI}

Localizado: EFEI - Escola Federal de Engenharia de Itajubá

UNIFEI - Universidade Federal de Itajubá

Oferece cursos em nível de Mestrado e Doutorado

Linhas de Pesquisas: Biomedicina, Biomateriais.

\section{DEPEB/FUNREI}

Localizado: Fundação Ensino Superior de São João del Rei UFSJ - Universidade Federal São João Del Rei

DEPEB - Departamento de Pesquisa Engenharia Biomédica Oferece cursos em nível de Pós-graduação, Mestrado.

Ano de inicio - 1994

Linhas de Pesquisas: Neurociência Experimental e Computacional 


\section{RIO GRANDE DO SUL}

\section{CEB/HSVP}

Localizado: Universidade de Santa Catarina, na cidade de Passo Fundo.

HSVP - Hospital São Vicente de Paulo

CEB - Centro Engenharia Biomédica,

(universidade e hospital são instituições distintas)

Oferece cursos em nível de Pós-Graduação, Mestrado e Doutorado.

Mestrado a distância em parceria CEFET - Paraná.

Ano de inicio - 1991

Linhas de pesquisas: Instrumentação Biomédica e Engenharia Clínica.

\section{LEB/UCPel}

Localizado: Universidade Católica de Pelotas

Laboratório de Engenharia Biomédica

Oferece em nível de Pós-graduação, Mestrado.

Ano de inicio - 1987

Linhas de pesquisas: Instrumentação Biomédica, Processamento de Sinais Biomédicos,

Filtros Adaptativos, Controle Ativo de Ruído.

\section{DEB/PUC-RS}

Localizado: Pontifícia Universidade Católica do Rio Grande do Sul

Laboratório Engenharia Biomédica

Oferece cursos em nível de Pós-graduação, Mestrado.

Ano de inicio - 1979

Linhas de pesquisas: Engenharia Clinica, Física Médica, Instrumentação Biomédica.

\section{UFRGS}

Localizado: Universidade Federal do Rio Grande do Sul

IPB - Instituto de Pesquisas Biomédicas

Oferece cursos em nível de Pós-graduação, Mestrado e Doutorado

Ano de inicio - 1997

Linhas de pesquisas: Pesquisa Biomédica, Pesquisa Basica. 


\section{PARANÁ}

\section{NEHOS-CEFET-PR}

Localizado: Centro Federal de Educação Tecnológica, sendo uma Instituição Federal na Cidade de Curitiba-PR

NEHOS - Núcleo Engenharia Hospitalar

Oferece cursos em nível de Pós-graduação, Mestrado e Doutorado.

Ano de inicio - 1991

Linhas de pesquisas: Engenharia Hospitalar, Sensores e Instrumentos de Aplicação Biomédica, Informática Aplicada à Biomédica.

\section{RIO DE JANEIRO}

\section{PEB/COPPE/UFRJ}

Localizado: Universidade Federal do Rio de Janeiro Instituto Alberto Luiz Coimbra, Ilha do Fundão.

COPPE - Comissão Pós Graduação e Pesquisa em Engenharia.

PEB - Programa de Engenharia Biomédica

Oferece cursos em nível de Pós-graduação, Mestrado e Doutorado.

Ano de inicio - 1971

Linhas de pesquisas: Ciências Engenharia combinando com Ciências Básicas à Engenharia.

\section{LAMPADA/UERJ}

Localizado: Universidade Estadual Rio de Janeiro

LAMPADA - Laboratório Médico de Pesquisas Avançadas

Oferece cursos em nível de Graduação, Mestrado e Doutorado.

Ano de inicio - 1986

Linhas de pesquisas: Informática em Medicina e Saúde.

\section{PARAÍBA}

\section{NETEB-UFPB}

Localizado: Universidade Federal da Paraíba, João Pessoa.

Oferece cursos em nível de Mestrado em Engenharia Biomédica especialização em Engenharia Clinica.

NETEB - Núcleo Estudos e Tecnologia em Engenharia Biomédica

Ano de início - 1976

Linhas de pesquisas: Informática Médica, Microcontroladores aplicados a Medicina, Processamento de Sinais Biológicos, Sistemas de Diagnóstico da Função Pulmonar, Processamento de Imagens Médicas. 


\section{SÃO PAULO}

\section{CAMPINAS}

\section{CEB/UNICAMP}

Localizado: Universidade de Campinas

CEB - Centro Engenharia Biomédica

Oferece cursos em nível de Mestrado e Doutorado

Ano de inicio - 1982

Linhas de Pesquisas: Bioengenharia - Engenharia Médica, Engenharia Reabilitação, Engenharia Clinica e Física Médica.

\section{DEB/UNICAMP}

Localizado: Universidade de Campinas

DEB - Departamento de Engenharia Biomédica

Oferece cursos em nível de Graduação, Mestrado e Doutorado.

Ano de início - 1974

Linhas de Pesquisas: Bioengenharia, Médica e Biológica, Engenharia Clínica e Engenharia de Reabilitação.

\section{RIBEIRÃO PRETO}

\section{FMRP-USP}

Localizado: Faculdade de Medicina em Ribeirão Preto

USP - Universidade de São Paulo

Ano de inicio - 1974

Linhas de Pesquisas: Ortopedia e Traumatologia

\section{SÃO CARLOS}

\section{EESC-FMRP-IQSC - Interunidades}

Localizado: Escola de Engenharia São Carlos

USP - Universidade de São Paulo

FMRP - Faculdade de Medicina de Ribeirão Preto

IQSC - Instituto Química São Carlos.

Oferece cursos em nível de Pós-Graduação, Mestrado em Bioengenharia.

Ano de início - 1979

Linhas de Pesquisas: Aparelho Músculo-esquelético (Biomaterias, Biomecânica, Instrumentação, Engenharia Reabilitação, Interação), Fonoengenharia. 


\section{IFSC/USP}

Localização: Escola de Engenharia São Carlos

IFSC -Instituto de Física São Carlos

Ano de inicio - 1954, em 1971 uniu-se Química, em 1994 só IFSC.

Linhas de Pesquisas: Laser aplicado à medicina.

\section{DEE/USP}

Localização: Escola de Engenharia São Carlos

DEE - Departamento Engenharia Elétrica

Ano de inicio - 1975

Linhas de Pesquisas: Processamento de Sinais e Instrumentação, Engenharia Reabilitação.

\section{SÃO JOSÉ DOS CAMPOS}

\section{IPD/UNIVAP}

Localização: Universidade do Vale do Paraíba IPD - Instituto Pesquisa Desenvolvimento, São José dos Campos.

Oferece cursos em nível de Pós-graduação, Mestrado e Doutorado

Ano de início - 1998

Linhas de Pesquisas: Engenharia Biomédica, Bioengenharia, Ciências Biológicas.

\section{MOGI DAS CRUZES}

Localização: UMC - Universidade de Mogi das Cruzes

Oferece cursos em nível de Pós-Graduação, Mestrado.

Ano de inicio - 1999

Linhas de Pesquisas: Estudo quantitativo do Sistema Cardiovascular, Instrumentação para Controle de Qualidade de Sistemas Radiológicos, Instrumentação para Eletrofisiologia Cardíaca, Instrumentação para Auxílio às Deficiências, Processamento de Imagens para Auxílio ao Ensino, ao Diagnóstico e às Deficiências Físicas.

\section{ARARAQUARA}

Localização: QUÍMICA

UNESP - Universidade do Estado de São Paulo

Ano de inicio - 1976

Linhas de Pesquisas: Biomateriais, pesquisas isoladas em bioengenharia para aplicação em Odontologia. 


\section{CIS-EPM/UNIFESP}

Localização: Universidade Federal São Paulo

EPM - Escola Paulista de Medicina

Ano de inicio - 1975

Linhas de Pesquisas: Cardiologia, Oftalmologia, Cirurgia Plástica, Reabilitação, Traumatologia.

\section{IEE/USP}

Localização: Universidade de São Paulo

IEE - Instituto de Eletrotecnica e Energia

Ano de inicio - 1989

Linhas de Pesquisas: Pesquisas isoladas e interdepartamentais.

\section{INCOR/USP}

Localização: Instituto do Coração do Hospital das Clinicas da Faculdade de Medicina da Universidade de São Paulo - INCOR-HCFMUSP

Ano de inicio: 1978

Linhas de Pesquisas: Pesquisa Básica, Cirurgia Experimental, Bioengenharia.

\section{LEB - Escola Politécnica/USP}

Localização: Escola Politécnica da Universidade de São Paulo.

LEB - Laboratório de Engenharia Biomédica

Bloco D2 e C1 do Edifício Engenharia Elétrica, no Campus da Cidade Universitária.

Ano de inicio - 1981

Linhas de Pesquisas: Engenharia Reabilitação, Neurofigiologia e Aquisição de Sinais, Neurociência Computacional e Modelagem em Biomedicina, Ensaios e Calibração.

\section{IDPC/SP}

Localização: Instituto Dante Pazzanese de Cardiologia

Ano de inicio - 1954

Linhas de Pesquisas: Cardiologia

Em todos os núcleos pesquisados, alguns não oferecem cursos, porém os seus produtos desenvolvidos são aplicados nos hospitais em parceria ou utilizados diretamente em pesquisas.

Uma especial atenção ao núcleo de interunidades, pois oferece mestrado em Bioengenharia, quando os demais núcleos oferecem formação em engenharia biomédica. 


\subsection{PRODUTOS E APLICAÇÃO DA BIOENGENHARIA NO BRASIL}

A figura 10 nos mostra a aplicação dos biomateriais nos seres humanos, e como isso auxilia sua vida, prolongando e melhorando a sua qualidade de vida. Os pontos que podem ser substituídos ou reparados são: dreno cerebral, placa de titânio, canal do nariz de silicone, aparelho de surdez, dentes de cerâmica, orelha de silicone, olho de vidro, maxilar inferior titânio, laringe com válvula para fala, marcapasso, ventrículo artificial, seios e mamilos de silicone, articulação ombro de titânio ou aço inoxidável e plástico, pele artificial, bacia artificial, vasos sangüíneo de sacron ou PTFE, fêmur de titânio, ligamento do joelho de carbono ou poliéster, articulações do pé de titânio ou outro material metálico, perna mecânica fibra de carbono, testículo de silicone e pênis de silicone.

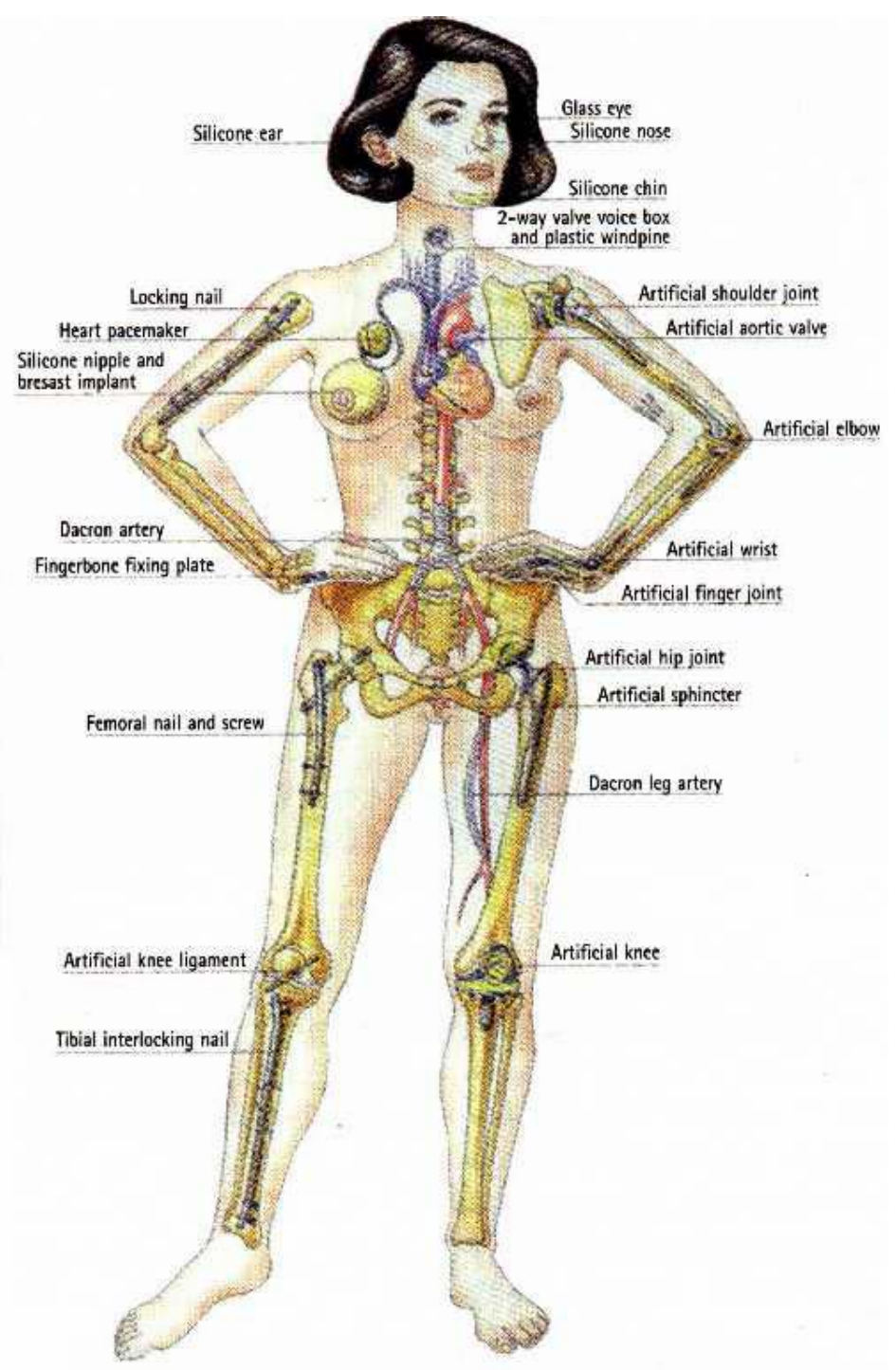

Figura 10 Exemplos dos biomateriais utilizados na substituição ou reparo de artes do corpo humano. Fonte: Otávio Villar da Silva Neto 


\subsection{APLICAÇÃO DA BIOENGENHARIA NA CARDIOLOGIA}

A bioengenharia está preocupada com os problemas do corpo humano. A disposição dos segmentos de aplicação da bioengenharia foi feita de acordo com os dados colhidos durante a minha pesquisa e de acordo com as datas de início no Brasil das especialidades: cardiologia, ortopedia, odontologia, oftalmologia, medicina regenerativa.

Como se sabe, o termo história reviva do grego história com significado original de busca, investigação ou pesquisa. É exatamente nesse sentido que será dado o enfoque básico deste trabalho, ou seja, a pesquisa sistemática da literatura disponível sobre o assunto em questão partirá dessa significação. Procuraremos apresentá-lo sob a forma de tópicos por assunto correlato e não apenas obedecendo à ordem cronológica, facilitando, assim, ao nosso ver, o desenvolvimento de fatos ocorridos no século XX na área da cardiologia e os desenvolvimentos na área da bioengenharia aplicados na cardiologia no Brasil.

$\mathrm{Na}$ verdade, foi somente há pouco mais de quatro décadas que a cirurgia cardíaca, nos moldes como a conhecemos hoje, começou a se delinear e, desde então, o progresso tem sido vertiginoso. $\mathrm{O}$ avanço científico do século $\mathrm{XX}$ desmistificou o coração como sede da alma, colocando-o em um patamar hierárquico não muito distante dos demais órgãos do corpo, iniciando-se assim, a história da cirurgia cardíaca.

Vale dizer que, na Europa, a cirurgia era, de forma geral, incipiente nessa época e, em termos de abordagem cardíaca, totalmente inexistente. Assim, foi na segunda metade do século XX que as grandes descobertas técnico-científicas vieram modificar profundamente os conhecimentos e pensamentos médicos: Pasteur (DUBOS, 1960) e seus discípulos, na França, e Kock, Erlich e Liebig, na Alemanha. E muitos outros criaram a microbiologia, a imunologia e a bioquímica (LONG, 1942). Exemplificando as contribuições da fisica, quase no fim do século XIX, Roentgen Alemanha (BLEICK, 1960) descobriu o raio-X e Eithoven - Holanda) descobriu o galvanômetro de corda, (MACIEL,1960) base dos futuros aparelhos de eletrocardiografia (BURCH,1964).

No Brasil, os primeiros especialistas surgiram, de maneira semelhante, na clínica geral. Segundo E. Magalhães Gomes (Murad: 1984, apud Stars Murad Netto), o estudo da cardiologia apareceu na obra "Lições de Clínica Médica" do Barão de Torres Homem (1870-1874). Entretanto, a cardiologia brasileira do século XIX é referida na bibliografia de D.A.Martins Costa (MARTINS COSTA, 1889); assim, já no primeiro tratado sobre "Moléstias do Coração e dos Grossos Vasos Arteriais" constam vinte e sete referências de trabalhos publicados no Brasil, de 1841 a 1889. É interessante notar que estes trabalhos, geralmente teses inaugurais, versavam, em sua maioria, sobre pericardite, angina de peito e lesões congênitas do coração. Destas referências devemos ressaltar os sete artigos de Costa Alvarenga, cinco das quais sobre cardiopatias congênitas. Outro grande nome foi, sem dúvida, Francisco de Castro, que iniciou um tratado de clínica Propedêutica que não chegou a terminar (MURAD NETTO, 1984). Em 1888, Castro traduziu, anotou e fez preleções sobre o trabalho de G. Mayer cujo título era "Formas Curáveis das Moléstias do Coração". 
Em síntese, no século XIX, escreveu-se no Brasil sobre clínica geral do coração, angina de peito, pericardite e cardiopatias congênitas. Nesta fase verdadeiramente inicial na cardiologia no Brasil - fim do século XIX e início de século XX - praticamente não houve contribuição original em relação à cardiologia internacional (JATENE, 2003).

Todavia, é importante lembrar que, partindo da Saúde Pública, por iniciativa do notável Oswaldo Cruz que estudara no Instituto Pasteur, foi criado o Instituto de Manguinhos na cidade do Rio de Janeiro em 1900-1903. Esse instituto - que não se limitou a um centro de ciência médica com formação de especialistas, voltada para doenças endêmicas do país - leva, hoje, o nome de seu criador (STEPAN, 1976). Tal foi a visão e a genialidade de Oswaldo Cruz que não levou muitos anos para que Manguinhos fosse a única instituição do país subdesenvolvido, tropical, conhecida nos centros científicos europeus. Ali muitas doenças foram estudadas e resolvidas pelo método de experimentação moldado não só na organização, mas também no espírito que animava o Instituto Pasteur de Paris (STEPAN, 1976).

Assim, o século XX foi saudado, no Brasil, pelo Instituto de Manguinhos, que formou experimentadores de elevado padrão científico. Apesar da extraordinária façanha de Oswaldo Cruz e, embora muito tenha sido realizado pelo Instituto, o Brasil não conseguiu criar verdadeiramente uma escola de medicina experimental que se caracterizasse como base da medicina atual, devido às condições sócio-econômicas do país.Foi fundado, ainda, na cidade de São Paulo, um Instituto semelhante cujo nome é Adolfo Lutz - instituto que tentou se equiparar e mesmo ultrapassar Manguinhos sem, entretanto, encontrar as condições necessárias (STEPAN, 1976).

Entre as grandes contribuições para o conhecimento das doenças infecciosas que Manguinhos ofereceu ao mundo ressalta o estudo completo da doença de Chagas. Carlos Chagas (1874-1934), de modo único em toda história da medicina, isolou e descreveu o agente causador, seu ciclo evolutivo e suas características biológicas e só então demonstrou a existência da doença (1909) e seu quadro anátomo-clínico, em colaboração com os patologistas do Instituto, Gaspar Vianna e MagarinoTorres entre outros, e seu grande amigo clínico e colaborador Eurico Villela (CHAGAS, 1968). Essa doença, além de sua grande importância - uma vez que afeta, aproximadamente dez milhões de brasileiros - é também aquela que provoca lesões no coração com tantas e tão diversas manifestações clínicas que, como dizia Francisco S. Laranja, toda a cardiologia pode ser nela estudada. Podemos concluir, sem dúvida, que Carlos Chagas foi o primeiro cardiologista moderno no Brasil (CHAGAS FILHO, 1968).

Deve ser destacada a contribuição de Francisco S. Laranja e colaboradores (Laranja-1956) no Instituto de Manguinhos, colaboradores estes que, além de terem mostrado a importância do bloqueio de ramo direto no diagnóstico populacional desta doença, criaram um Centro de Estudos da Doença de Chagas, onde desenvolveram, ao lado do cuidadoso estudo clínico, a parte experimental a ela referente. Carlos Chagas e seus colaboradores diagnosticaram a cardiopatia chagásica, primeiro grande estudo científico de uma doença cardíaca no Brasil. Esta foi, indubitavelmente, uma contribuição ímpar e magnífica para a cardiologia mundial (LARANJA et al, 1956).

Segundo o radiologista Duque Estrada, por volta de 1910-1912 chegou os primeiros aparelhos de eletrocardiografia do tipo galvanômetro de corda. São dignos de menção os trabalhos: Almeida Magalhães- Rio de Janeiro - sobre o "Coração no beribéri" (MAGALHÃES, 1901) e a série de publicações de Osvaldo de Oliveira "Do choque precordial - 1905" (OLIVEIRA, 1934) "Da percussão Dorsal da Aorta - 1914" "Cardiologia Clinica" e "Patogenia dos Sopros Acidentais do Coração - 1917" 
"Insuficiência Aórtica sem Sopro- 1918 "e vários outros trabalhos sobre a cardiologia nas suas "Lições de Clínica Médica- 1924"

A correção cirúrgica da estenose valvar mitral reumática remonta a 1923: utilizando um tenótomo, foi realizada com sucesso a comissurotomia mitral por via transventricular por Elliot Carr Cutler e Samuel Levine. Henry Soutlar, em 1925, fez a abordagem da valva mitral através do apêndice atrial esquerdo, realizando a comissurotomia com o auxílio do próprio dedo indicador. O desenvolvimento da cirurgia da valva mitral estenótica só foi retomado em meados da década de 40, quando os Drs. Dwight Harken e Charles Bailey, independentemente, passaram a praticar a valvuloplastia em larga escala (COHN, 1993).

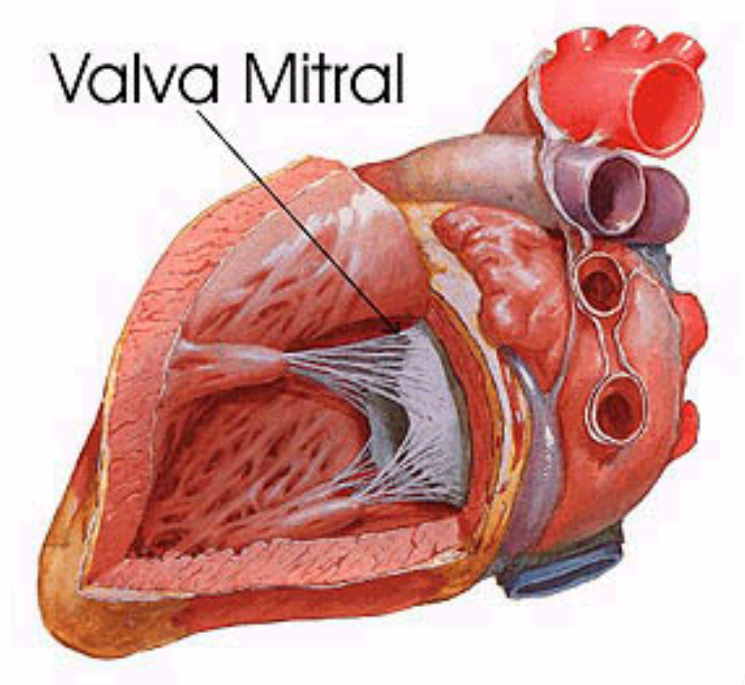

Figura 11 Valva Mitral

Fonte-Disponível em: $<$ http://www.eaagostini.com.br Acesso em: 20 dez.2003

No Brasil, algumas pessoas se destacaram de maneira singular na área da cardiologia. Dante Pazzanese é uma delas: em 1928, trabalhava voluntariamente como assistente na Faculdade de Medicina de São Paulo. Trabalhou na organização e direção do serviço pioneiro de eletrocardiografia da faculdade de Medicina de São Paulo, então instalada na Santa Casa de Misericórdia. Como se pode imaginar, as dificuldades da época eram muitas. Mesmo assim, Dante adquiriu um Boulitte, aparelho francês moderno e mais simplificado, pelo qual se obtinham belo traçados-método para o registro em forma de gráfico, das correntes elétricas pelas pulsações do coração. $\mathrm{O}$ pagamento foi feito a duras penas; "Apesar do grande apoio da classe médica paulista, vale a pena contar que levou 8 anos para pagar os 12 contos, preço do aparelho, à tolerantíssima Casa Lutz Ferrando, pois embora fosse o único a ter eletrocardiógrafo no estado, passava, às vezes, de dois a três meses sem fazer um traçado"(REVISTA IDPC, Ano 1). Até 1933, Dante foi o único especialista a realizar a eletrocardiografia, ministrou cursos sobre eletrocardiografia, sendo o primeiro deles em 1930, com a coordenação da Associação Paulista de Medicina.

John Gibbon, em 1931, trabalhando com o Edward D. Churchill, vendo um paciente morrer na mesa operatória quando se tentava remover um êmbolo maciço da artéria pulmonar, imaginou que se fosse possível manter a circulação e a oxigenação, o 
paciente poderia ter sido salvo. Seus trabalhos prosseguiram em 1934, e havia desenvolvido uma máquina capaz de manter a respiração e a circulação em pequenos animais.

Vale dizer que foi criada, no Hospital Geral da Santa Casa de Misericórdia do Rio de Janeiro, a Sociedade de Cardiologia e Hematologia, em 1933, de duração efêmera. No Brasil, na primeira metade da década de 30, a cultura brasileira, especialmente a médica, era toda de origem francesa e ocasionalmente alemã. Todo o nosso curso médico foi baseado em livros franceses. Ressalta-se que a medicina da França estava muito atrasado em relação à medicina anglo-americana e a cultura cardiológica alemã já se ressentia grandemente da perseguição política.

Não havia, então, o hábito de leitura de revistas médicas e as viagens de estudo ao exterior eram mais em busca de informações do que de praxis. É evidente que havia exceções. Devido às dificuldades financeiras era natural que, naquela época, procurassem o exterior, em sua maioria, médicos mais velhos, com menores oportunidades de participarem de grupos de estudos (JATENE, 2003).

Em 1937, Dante foi convidado pelo então prefeito da cidade de São Paulo, Fábio Prado, para dirigir o serviço de Cardiologia do Hospital Municipal, foi nessa época, no HM, que tiveram início os estudos da fonocardiografia e quimografia e onde, pela primeira vez, foi empregada a abreugrafia - método do cientista brasileiro Manuel de Abreu, para fixar fotograficamente e em tamanho reduzido a imagem observada na radioscopia; roentgen-fotografia (PAZZANESE, 1940).

O segundo fator responsável pelo rápido avanço na cardiologia Brasil foi, sem dúvida, a troca do modelo francês pelo modelo americano, em 1939. O primeiro cardiologista a ir ao exterior foi o Dr. Lemos Torres - São Paulo (SEGADAS, 1941). Estimulado por Torres, Pazzanese ruma para a Universidade de Michigan, em Ann Arbor, Estados Unidos, para realizar estágio no Serviço de Cardiologia, orientado para a cardiologia americana, cujos progressos eram muito mais destacados e importantes que os da cardiologia anglo-franca-alemã, que eram as mais difundidas no Brasil.

Na segunda metade da década de 30 e início da de 40, houve grande surto e progresso na cardiologia no Brasil, motivado por dois fatores principais: grupos de estudos da especialidade se congregam em entidades que permitiram maior aprofundamento e proporcionou maior divulgação dos temas estudados. O primeiro curso Intensivo de Cardiologia para Médicos foi ministrado no Hospital Municipal, em 1941, logo depois da volta de Pazzanese do exterior. A determinação em divulgar os conhecimentos adquiridos e seu entusiasmo fez crescer o número de alunos, de tal forma que o evento tornou-se o embrião da Sociedade Brasileira de Cardiologia. Foi publicado por Dante Pazzanese um livro sobre "Fonocardiografia-1940" (PAZZANESE, 1940) e um sobre "Modificações de Forma do Eletrocardiograma - 1942" (PAZZANESE,1942).

Jáiro Ramos, em 1935. Publicou um livro sobre Eletro cardiografia. Na Bahia, foi publicada, em 1938, por Adriano de A. Ponde, uma tese clínica experimental sobre o Infarto do Miocárdio. Em 1942, Pazzanese trouxe dos Estados Unidos o venerado professor Frank Norman Wilson para um curso de especialização da parte experimental da eletrocardiografia. Nessa época, o HM era equipado com aparelhagem avançada, como eletrocardiógrafos de canais múltiplos e portáteis, fonocardiógrafos de grande fidelidade, adaptáveis a alto-falantes e estetofones auriculares, além de aparelhos de raios-X com quimógrafos e quimoscópios, para analise dos movimentos do coração. Portanto, a Cardiologia no Brasil progrediu sensivelmente e já estamos muito mais preparados para compreender os seus avanços. O papel da SBC - Sociedade Brasileira 
de Cardiologia, fundada em 1943, liderada por Dante Pazzanese, que foi seu primeiro presidente - agregou e conduziu os cardiologistas do Brasil (MURAD NETTO, 1984).

De 1939 até o final da II Grande Guerra Mundial (1945) e, mesmo antes desta data, as relações entre o Brasil e os Estados Unidos da América do Norte tornaram-se muito estreitas, vindo para o Brasil grande número de norte-americanos. Logicamente, criou-se uma grande rede de interesses recíprocos que resultou em facilidades para o estágio de médicos brasileiros em hospitais americanos. Junta-se a isso a circunstância de que o exército dos Estados Unidos havia recrutado grande número de médicos civis, desfalcando suas organizações hospitalares. Esta oportunidade única fez com que centenas de médicos brasileiros conseguissem bolsas de estudo pagas pelo governo americano e fossem trabalhar em seus hospitais, dentro da metodologia lá utilizada (MURAD NETTO, 1984).

Foi possível estudar, atuar com responsabilidade integral e trabalhar metodicamente, sob a supervisão direta dos médicos americanos altamente capacitados. A língua inglesa tornou-se mais acessível, mas surgiu um obstáculo que custou a ser transposto. Muitos brasileiros que voltaram perderam o nosso fundo cultural $\mathrm{e}$ trouxeram para o Brasil uma cultura à qual estávamos pouco familiarizados. Outro obstáculo não menos importante foi o choque entre a nossa formação cultural européia e a americana. Nessa época, não era raro encontrar colegas irritados com os artigos médicos americanos que se baseavam somente em estatísticas, sem especulação teórica conclusiva e que não alcançavam a interação do autor. Este conflito prejudicava nitidamente a comunicação entre os que traziam as novidades e os que as recebiam (OLIVEIRA, 1934).

A eletrocardiografia foi introduzida, em São Paulo, por Dante Pazzanese que criou o Serviço de Cardiologia do HM - Hospital Municipal, na Rua Vergueiro. Aí foi realizado, na década de quarenta, o primeiro curso de cardiologia de São Paulo, onde grandes professores como Jairo Ramos e Luiz Venere Décourt, estiveram e participaram. Ainda neste hospital, foi instituído o primeiro serviço de cardiologia da cidade de São Paulo, constituído por: Dante Pazzanese, Leovigildo Mendonça de Barros, Olavo Pazzanese, Alberto Ferreira, Sampaio Correia, Silvio Bertacchi, e Astolfo Oliveira. Esse foi, pois, o grupo original (BURCH, 1964).

Embora não existisse ainda nem a Faculdade de Medicina da Universidade de São Paulo, nem o HSP - Hospital São Paulo, o Dante já era reconhecido como uma das maiores lideranças da cardiologia no Estado. As pessoas acreditavam no Dante pelo que ele já havia feito pela cardiologia. O Icesp - Instituto de Cardiologia de São Paulo se organizava especificamente para a cardiologia, o que na época não existia. A cardiologia era mais ou menos aceita, mas ainda não havia uma instituição que cuidasse especificamente de doenças do coração, e Dante tinha uma ambiciosa proposta de criar uma grande instituição (REVISTA INCOR, 1999).

Por outro lado, esta nova técnica de eletrocardiografia, permitiu desvendar, no homem, um campo até então absolutamente fechado à verificação direta da circulação pulmonar e sua patologia e relacioná-la como um todo à circulação sistêmica. Vários centros de diversos países contribuíram muito para o melhor conhecimento do comportamento da pequena circulação. Como contribuição da cardiologia brasileira, podemos citar os trabalhos de Mario Rigatto (COURNAND et al, 1945) Nelson Botelho Reis e colaboradores (COURNAND, 1950) e Ayres H. P. da Fonseca Costa (RIGATTO, 973).

Um outro método, extremamente importante, teve inicialmente pouca utilização, por exigir material e aparelhagem de alto custo: a angiocardiografia de Castellamos A. de Carvalho Azevedo. Este estudioso tentou métodos menos 
dispendiosos para contornar essa dificuldade; infelizmente, os resultados nem sempre eram satisfatórios e confiáveis, razão pela qual não foi adotada em outros centros.

Quem melhor resolveu o método angiocardiográfico no Brasil foi Darci Ilha (FONSECA, 1970) que aprendeu na Suécia e a trouxe para Porto Alegre, em 1948. Foi, sem dúvida, o pioneiro e maior divulgador do método no Brasil.

O primeiro cateterismo cardíaco foi realizado no Rio de Janeiro, em fins de 1949, por Carvalho Azevedo, que contou com a valiosa colaboração de Armando Ney Toledo. A primeira cirurgia cardíaca a céu aberto, realizado com sucesso, só aconteceu em 1952, quando o Dr. John Lewis corrigiu uma comunicação interatrial de $2 \mathrm{~cm}$ de diâmetro, sob visão direta, com interrupção do fluxo nas cavas e hipotermia corporal moderada no Hospital da Universidade de Minnesota - EUA (LILLEHEI, 1994).

Brasileiros pioneiros da cirurgia cardíaca se iniciaram em Minnesota, sob a orientação do W. Lillerhei, com destaque para: Euryclides de Jesus Zerbini, Delmont Bittencourt, André Esteves Lima, Hugo Felipozzi, Domingos Junqueira de Morães, que difundiram conhecimentos, formaram escolas e fez da cirurgia cardíaca um marcador da viabilidade do nosso país. A primeira dilatação da estenose áortica no Brasil, com auxilio do dilatador de Bailey, foi realizada em 1953, no Hospital São Paulo, Escola Paulista de Medicina, por Ruy Margutti (MARGUTTI et al, 1955).

Graças à amizade com o deputado Narciso Pieroni, seu paciente, que era líder do governo de Lucas Nogueira Garcez na Assembléia Legislativa Dante consegue que o governador encaminhe à Assembléia o projeto de criação do Icesp. Assim, em São Paulo, em 1954, foi aprovado o Icesp - Instituto de Cardilogia do Estado de São Paulo que inicia suas atividades, a princípio com poucos recursos, em um antigo casarão adaptado na Av. Paulista, na esquina com a Carlos Sampaio, em frente ao Instituto Pasteur. Apesar da estrutura precária e da limitação de recursos, a pequena sede simbolizava uma expressiva vitória naquela época em que a cardiologia ainda lutava para ganhar espaço dentre as especialidades médicas. Desse modo, desde os primeiros tempos, o Icesp já prometia se tornar um dos grandes celeiros de talento do país. Pazzanese foi eleito representante do Brasil pela Assembléia Geral de Washington, no Conselho da Sociedade Internacional de Cardiologia em 1954 (REVISTA INCOR, 1999).

Rio de Janeiro e São Paulo se tornaram os irradiadores do método que se espalhou por todo o Brasil e hoje contamos com vários centros de cateterismo cardíaco de alto gabarito. No norte, foi fundado, por Simões Barbosa, em 1956, na cidade do Recife, o Instituto de Cardiologia da Universidade Federal de Pernambuco - UFPe. Atualmente, este Instituto foi absorvido pelo Departamento de Clínicas Médica e Cirúrgica da UFPE, onde foram elaborados trabalhos originais sobre a esquistossomose Cardiopulmonar (CAVALCANTI et al, 1962) e a cirurgia da endomiocardiofibrose, pioneira no Brasil.

Dante Pazzanese começou a fazer gestões para conseguir uma área mais adequada, e conseguiu o terreno e construiu um ambulatório de mil e poucos metros quadrados, inaugurado em 1958, na avenida XV de Novembro, em São Paulo. Atualmente, tem o nome de Av. Dante Pazzanese. Havia os Institutos que atendiam os cobertos pela previdência. Tinham IAPC, Iapi, Iapetec, enfim eram categorias profissionais e cada uma tinha seu próprio instituto (REVISTA INCOR, 1999).

Instituições como o Instituto de Cardiologia do Estado e o $\mathrm{HC}$-Hospital das Clínicas, atendiam basicamente a clientela que não podia pagar e não tinha nenhuma cobertura. O Estado tinha que cobrir as despesas.

Com a mudança do Instituto para o Ibirapuera (bairro em São Paulo), o Dr. Dante conseguiu convencer o governador do Estado Jânio da Silva Quadros de que um 
serviço médico, um instituto de cardiologia, não poderia ficar exclusivamente na dependência de recursos do orçamento. Os recursos eram decididos com um ano de antecedência e, geralmente, eles eram insuficientes para manter a instituição em funcionamento, especialmente porque sempre teve um sistema inflacionário que fazia com que os recursos se esgotassem em meados de julho ou agosto. Assim, a proposta apresentada ao governador era: a de instituto cobrar de quem pudesse pagar. E esse recurso não seria incorporado ao orçamento do Estado, ficando na instituição para que ela pudesse avançar na pesquisa, na remuneração de pessoal e na própria agilidade do sistema administrativo. O governador aceitou e foi, portanto, criado o Fundo de Pesquisa do Instituto de Cardiologia do Estado de São Paulo. Foi uma iniciativa inédita (REVISTA INCOR, 1999).

Esse foi o primeiro fundo de pesquisa do Estado de São Paulo, criado por volta de 1958. Com isso passaram a existir seis categorias de pacientes: Categoria $\mathrm{C}$ pagava integralmente; Categoria A não pagava nada; Categoria B, subdividida em B1 que pagava $10 \%$, categoria $\mathrm{B} 2$ que pagava $20 \%$, categoria $\mathrm{B} 3$ que pagava $40 \%$, e categoria B4 que pagava $60 \%$. Os serviços prestados pelo instituto tinham seus valores relacionados no Diário Oficial (jornal oficial do governo). Os jornais da época traziam uma lista de preços do Instituto de Cardiologia do Estado de São Paulo. Este dinheiro ficava na instituição, desvinculado do orçamento e manejado por seus dirigentes e por um representante da Secretaria de Saúde. Logo, foi esse sistema de fundo de pesquisas que permitiu o salto dado pelo instituto (REVISTA INCOR, 1999).

$\mathrm{O}$ instituto, nos primeiros tempos no Ibirapuera, tinha um ambulatório e contava com pouco mais de 1.000 metros quadrados de área construída. Não tinha internação. Mas tinha cateterismo cardíaco, vectocardiografia. $O$ que se fazia em cardiologia nessa época era diagnóstico, intervir nos pacientes e acompanhá-los. Mas o que deu muito prestígio foi a determinação das lipoproteinas por ultracentrifugação. Este equipamento funciona até os dias atuais. O instituto foi o primeiro serviço da América do Sul a instalar a determinação das lipoproteinas por ultracentrifugação. Como isso só tinha no Icesp, a parte ambulatorial e de diagnósticos eram muito bom. Dante percebeu a grande importância das lipoproteínas e o instituto era um dos poucos do mundo que determinava as lipoproteinas por ultracentrifugação, estabelecendo um padrão de risco das pessoas com as proteínas de baixa densidade, a LDL, a HDL. Ou seja, o que é moda nos dias atuais, o instituto fazia desde de 1958 (REVISTA INCOR, 1999).

Havia a proposta de construção de um hospital. Como os orçamentos não permitiam que isso se materializasse, decidiu-se fazer um convênio para aluguel de 12 leitos no Hospital da Beneficência Portuguesa. O secretário de saúde Fauze Carlos, foi quem promoveu esse convênio. A partir de então, o instituto passou a ter local não só para internar doentes, mas para desenvolver a cirurgia cardíaca, que estava se iniciando.

O primeiro Instituto particular de Cardiologia foi criado na cidade de São Paulo pela Fábrica de Cigarros Sudan, recebendo o nome de seu fundador-Instituto de Cardiologia Sabbato D’Angelo, em 1958 (SCHLESINGER et al, 1948). Esse Instituto, na sua fase aúrea, era uma entidade modelar, muito bem instalado, constando de parte clínica, hemodinâmica, experimental e cirúrgica, constando no corpo clínico: Hugo J. Felipozzi, Rubens de Guimarães Santos, Maria Vitória Martin, Adauto Barbosa Lima, Josef Feher (SCHLESINGER et al, 1948). Em razão de dificuldades financeiras, a Instituição teve que abandonar suas instalações e hoje funciona no Hospital Geral da Santa Casa de Misericórdia da cidade de São Paulo.

No HC - Hospital das Clínicas e no HSP - Hospital São Paulo, algumas experiências importantes começaram a se desenvolver, com Hugo Felipozzi. No 
instituto, o chefe do serviço cirúrgico era o Prof. Euryclides de Jesus Zerbini, que levou alguns de seus assistentes, como: Rubens Arruda, Luís Losso, Adib Domingos Jatene que, nessa época, começavam a residência médica. A residência médica começou no Brasil em 1959 e foram criadas nesse período cinco vagas em cardiologia clínica, sendo os primeiros alunos Eduardo Sousa, Valmir Fontes, Helio Germiniani, João Bezerra Neto, Lincoln Fernando Mendes. Neste ano, Pazzanesse foi convidado especial do I Congresso Sul-americano de Aterosclerose em 1959, em Buenos Aires-Argentina. O presidente da República do Brasil, Juscelino Kubitscheck de Oliveira, nomeava Dante Pazzanesse Comendador da Ordem do Mérito Médico, no ano de 1959. Sendo que no ano de 1960, ele foi relator oficial do Congresso de Arteriosclerose em Milão-Roma (REVISTA IDPC -Ano 2).

As cirurgias começaram no Instituto em 1961, quando Jatene se transfere definitivamente para o Icesp. Começa a trabalhar visando as cirurgias e montada a Oficina Experimental de Pesquisas, que depois virou um departamento técnico de bioengenharia. Já havia sido feito um modelo de coração-pulmão artificial no HCHospital das Clínicas, mas o equipamento usava um oxigenador de discos que consumia muito sangue. E foi no Icesp que então foi desenvolvido o coração-pulmão artificial com oxigenador de bolhas (JATENE, 2003).

Por meio do Funcor, criado em 1961, a SBC estimula a pesquisa científica e tecnológica no campo da cardiologia e realiza serviço de utilidade pública, ao divulgar aspectos epidemiológicos das doenças cardiovasculares, realizando campanhas de conscientização para esclarecer a população, em relação à prevenção e ao controle das doenças cardiovasculares (CHAGAS, 1981).

A residência em cirurgia começou em 1962, e o primeiro residente foi o Dr. Paulo Paulista, com a coordenação de serviço do Dr. Jatene. No ano seguinte, vieram os novos Dr. Luiz Carlos Bento de Souza e o Dr. Hélio Pereira de Magalhães. Depois vieram outros como o Dr. Décio Kormann, Dr. Jarbas Dinkunysen, e a essa altura, o convênio com a Beneficência Portuguesa já havia sido ampliado de 12 para 30 e depois para 40 leitos. Nesse momento, começaram as gestões para a construção da unidade hospitalar do instituto, o que foi um trabalho essencialmente político. Só alcançaram essa conquista devido ao que o Icesp já havia conseguido (REVISTA IDPC, Ano 1).

Foi fundada em 1963, a Anac - Associação Nacional de Assistência ao Cardíaco, entidade filantrópica sem fins lucrativos, localizada na rua Caravelas $n^{\circ} 527$, Vila Mariana, bem ao lado de um dos portões do IDPC. Sua principal atividade foi a administração e manutenção da Casa do Cardíaco, localizada no Parque Real, em Diadema, em terreno de $8.000 \mathrm{~m}^{2}$ doado pelo comandante Lineu Gomes, grande amigo de Dante Pazzanese. Neste local, três pavilhões, perfazendo uma área de $850 \mathrm{~m}^{2}$ abrigam 60 leitos, destinados a pacientes cardiovasculares que recebem abrigo gratuito, inclusive para um acompanhante, nas fases pré e pós-operatórias (ANITA PAZZANESE). No, Brasil em 1964, o Icesp, pela primeira vez, fabrica as válvulas artificiais. Essa válvula era uma gaiola metálica com uma bola de silicone dentro e um colarinho de tecido para o médico fixar no coração (REVISTA IDPC, Ano 1)

Os modelos importados custavam \$ 320 dólares a unidade. O Brasil não tinha como adquirir em grande quantidade, além da importação da época ser muito difícil. $\mathrm{O}$ Dr. Dante incentiva a criação de uma válvula brasileira, que depois de pronta tinha um custo de \$ 40 dólares. Isso contribuiu diretamente para o avanço do Brasil no que diz respeito à cardiologia. Na época na oficina trabalhavam o torneiro Sr. Jeremias, Sr. José Francisco Biscegli, hoje o atual chefe da divisão de Bioengenharia, e Sra, Mercedes, que ainda é funcionária nos dias atuais (BISCEGLI, 2001). 
Depois veio o Marca-passo, e o desfibrilador, que deu muito prestígio ao instituto. O governador da cidade de São Paulo, Abreu Sodré, concedeu um empréstimo para a fabricação de 200 unidades marca-passo. A idéia era pagar esse empréstimo com a venda de uma parte dos marca-passos. Os demais eram para quem não pudesse pagar. Em seis meses, pagou-se o empréstimo que o governo concedeu, e considerava a fundo perdido (JATENE, 2003).

Com todas essas realizações e mais uma experiência cirúrgica que era, sob algum aspecto, em volume, até maior do que no $\mathrm{HC}$, o instituto tinha adquirido uma credencial. E foi com essa credencial que o Dr. Dante conseguiu, junto ao governador Laudo Natel, a verba para a construção do prédio onde está a unidade antiga com 100 leitos. Foi difícil conseguir a autorização do governador para a construção e os recursos no orçamento, mais difícil ainda foi conseguir a liberação dos recursos. O Dr. Dante era o elemento chave dessa conquista, porque ele era um homem de enorme prestígio, com visão extraordinariamente ampliada (BISCEGLI, 2001).

Dr. Eduardo Sousa foi a Boston estudar cateterismo cardíaco em congênitos. Em 1966, ao retornar, quis ir a Cleveland para conhecer a cinerocoronariografia; como esse trabalho era ainda preliminar, lhe foi negado. Ao tomar conhecimento desse fato, o Dr. Dante disse: "você está dizendo que com essa técnica é possível ver a artéria coronária por dentro e identificar as lesões com o indivíduo vivo? Isso é uma coisa extraordinária" (PAZZANESE, 1966) Uma semana depois, o Dr. Eduardo embarcou para Cleveland. A viagem do Dr. Eduardo deu ao Icesp a primazia da cirurgia de coronária.

Como se vê, a visão de futuro do Dr.Dante era abrangente e, em razão disso, o instituto progrediu consideravelmente. Fica provado, portanto, que é a dimensão do dirigente a responsável pela dimensão da instituição e a capacidade de fazê-la progredir.

Adib Domingos Jatene iniciou o seu próprio serviço com várias contribuições originais na área da bioengenharia: incluem-se os "oxigenadores de bolhas e de membrana, a válvula de disco basculante, dos quais possui a patente. Estão sendo produzidas industrialmente sob licença e utilizados no país e no exterior" Em parceria com Eduardo Issamu Nakayama, Leiner Adolfo Alberto, receberam prêmio pelo invento "bomba rotativa axial para assistência circulatória".

Pazzanesse relata que, em 1970, a escola norte americana foi a responsável pela evolução do aparelho eletrocardiográfico, abandonado pelo médico inglês Thomas Lewis, que o considerava esgotado após o estudo das arritmias.Anita (esposa de Dante) relata que, para Pazzanese, o principal objetivo do Instituto era a assistência social e não transformá-lo numa entidade de ensino. A parte científica viria para não deixar as atividades do instituto virarem rotina burocrática, de funcionalismo público (REVISTA INCOR, 1999)

Em 1975, o Icesp mudou de nome e passou a se chamar Instituto Dante Pazzanese de Cardiologia, fazendo uma justa homenagem ao seu criador. O instituto foi criado, dentro de um conceito de coesão interna que sempre o fez progredir. No IDPC Instituto Dante Pazzanese de Cardiologia, a instituição vem sempre em primeiro lugar e esse é o maior legado que o Dr. Dante Pazzanese deixou (BISCEGLI, 2001).

O Dr. Zerbini assumiu sucessivamente a chefia do Laboratório Experimental e de Pesquisa, a chefia da Seção de Cirurgia, a diretoria médica e a diretoria geral. Foi responsável pela organização da Oficina de Bioengenharia, hoje denominada Centro Técnico de Pesquisas e Experimentos, desenvolveu e planejou vários instrumentos e aparelhos. Dentre eles estão os oxigenadores de bolhas e de membrana e a válvula de disco basculante, produzidos industrialmente sob licença e largamente empregados no Brasil e exterior. Não pode deixar de ser lembrado que Dante Pazzanese, Adib Jatene e 
Zerbini, entre outros, trabalharam em equipe que posteriormente se desfez (ANDRADE, 2001). Observe na figura 12 uma foto do prof. Zerbini quando estava saindo, de uma das muitas cirurgias cardíacas que realizou.

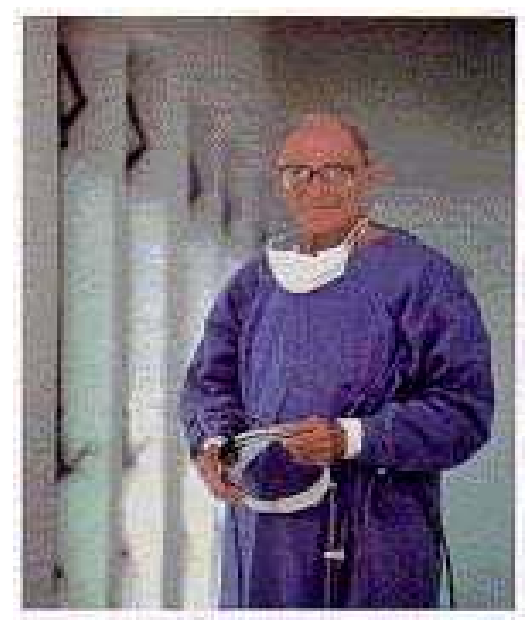

Figura 12 Euriclides de Jesus Zerbini, pioneiro em transplantes cardíacos no Brasil

Fonte-Disponível em: $<$ http://www.zerbini.org.br Acesso em: 20 dez.2003

Apesar de transplante de órgãos não ser considerado como bioengenharia, vou fazer um comentário sobre o que é esta cirurgia que no Brasil, em 1968, Euriclides de Jesus Zerbini e sua equipe de trabalho realizaram o primeiro caso de transplante de coração.

Para que este tipo de cirúrgia seja possível de ser realizada necessita-se de apoio de máquinas de circulação extracorpórea, sendo estas máquinas consideradas pelos cirurgiões como produto de bioengenharia.

\subsubsection{Transplantes}

No Brasil, são realizados, em média, cerca de 150 transplantes de coração por ano. Em 1981, o transplante duplo de órgãos de coração e pulmão foi introduzido em pacientes com comprometimento severo desses dois órgãos. Em 1995, foram praticamente 2000 transplantes deste tipo feitos no mundo inteiro.

Há duas barreiras no incremento e no sucesso dos transplantes. Em 1983, o principal obstáculo ao sucesso dessas cirurgias era a rejeição do órgão doado pelo paciente receptor. A introdução da ciclosporina, uma droga que ajuda a suprir a rejeição, permitiu um melhor controle e aumentou significativamente a sobrevivência dos pacientes transplantados. Hoje, há duas outras drogas que complementam esse trabalho e isso fez com que mais de $80 \%$ dos pacientes sobrevivessem uns anos a mais (ZERBINI, 1974).

Note na figura 13 a análise comparativa anual do número de transplantes - por órgão no período de 1995 a 2002. Os órgãos transplantados são: rim, fígado, coração, pâncreas. 
Análise Comparativa Anual do Número de Transplantes - por Órgão

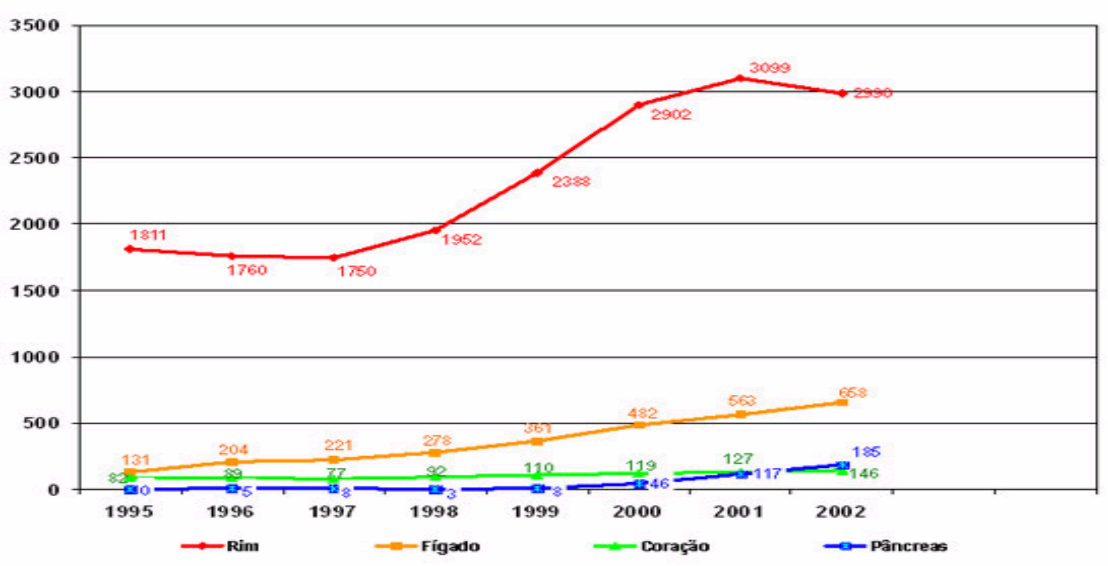

Figura 13 Análise Comparativa Anual do número de transplantes - por órgão de 1995 a 2002 Fonte-Disponível em:<http://www.abto.com.br Acesso em 20 dezembro 2003

No caso dos transplantes duplos, o sucesso atinge $60 \%$ em sobreviver um ano ou mais. Intensas pesquisas continuam sendo feitas tanto para controlar melhor a rejeição como para incrementar o tempo de vida. A segunda barreira é o número de doadores. Diversos órgãos públicos e privados no mundo inteiro têm realizado campanhas de conscientização popular e têm, ainda, uma estrutura atendimento especializado para tais fins (ABTO, 2002).

Como se sabe, o transplante é a substituição de um órgão doente, seja o coração ou o coração e o pulmão junto, por um órgão sadio de uma pessoa que vier a morrer chamada de doadora. O órgão doado é removido por completo e transportado rapidamente para o local onde se encontra o paciente na espera. O órgão é mantido em temperatura baixa e em soluções especiais para conservarem sua vitalidade. Pdemos verificar na figura 14, que o número de transplantes cardíacos no Estado de São Paulo é muito maior em relação a outros estados brasileiros.

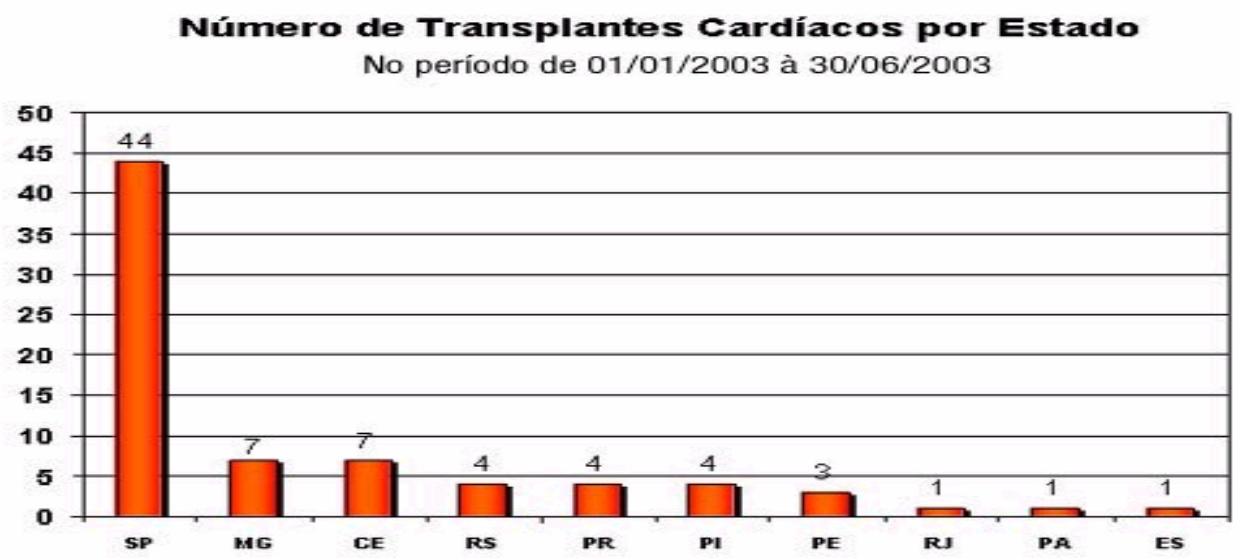

Figura 14 Número Transplantes Cardíacos por Estado, no período de 01/01/2003 à 30/06/2003. 
Durante a cirurgia, o paciente que receberá o órgão é mantido com equipamentos artificiais que realizam as funções do coração e do pulmão. Esses equipamentos bombeiam o sangue para o corpo, removendo o dióxido de carbono e substituindo-o por oxigênio (circulação extracorpórea).

Assim, os cirurgiões retiram o coração doente, com exceção da parede posterior do átrio, que é o compartimento superior do coração. As paredes posteriores de átrio do novo coração são abertas e o novo coração é encaixado no local. No caso do transplante duplo de pulmão e coração, os dois órgãos são retirados simultaneamente, sendo feito o implante do pulmão primeiro, em seguida o do coração. Os cirurgiões conectam os vasos sanguíneos fazendo o sangue circular pelo pulmão e coração. Em certos casos, é preciso um choque elétrico para iniciar os batimentos do novo coração. Após a verificação das conexões de todos os vasos, o paciente é liberado da circulação extracorpórea. A recuperação acontece em poucos dias após a cirurgia e, se não houver sinais de rejeição do novo coração, a alta hospitalar é prevista dentro de duas semanas.

A indicação do transplante é feita quando o coração está falhando em suas funções e não responde mais a outra forma de tratamento, desde que o resto do organismo esteja em boas condições. As principais causas de essas pessoas receberem o transplante são: as cardiopatias que seriam doenças que atingem o músculo do coração; a doença severa das artérias coronárias, bloqueando a chegada de sangue ao músculo; os defeitos cardíacos de nascimento que são as doenças congênitas severas (ZERBINI, 1974).

O transplante duplo de coração e pulmão é realizado quando o pulmão está realmente comprometido em suas funções, envolvendo diretamente o coração. Outras alternativas de tratamento nesses pacientes são consideradas ou testadas. As principais doenças que indicam o transplante duplo são: a hipertensão pulmonar severa quando a pressão sangüínea dentro dos vasos pulmonares encontra-se muito elevado, impedindo o fluxo de sangue e a troca de oxigênio com o resto do corpo e os defeitos de nascimento como a patologia de Eisenmenger, que é a hipertensão pulmonar (REIS et al, 1978).

Pessoas abaixo de 60 anos são freqüentemente os maiores candidatos. Pacientes abaixo de 45 anos são geralmente os candidatos ao transplante duplo. Em ambos, é preciso os casos, para que o transplante ocorra, que a doença esteja em estado severo, que outras terapias estejam falhando e que o resto do organismo esteja saudável.

Os doadores são indivíduos que tiveram morte cerebral e são mantidos vivos através de equipamentos. Em geral, são vítimas de acidentes de carro, derrame cerebral, (acidentes vasculares cerebrais) suicídios ou traumas cerebrais. A maioria dos doadores escolhidos tem menos de 45 anos. Apesar disso, não há órgãos suficientes. Muitos pacientes aguardam meses para o transplante, muitas vezes sem sucesso.

As causas mais freqüentes de morte pós-transplante são as infecções e a rejeição. Os pacientes em uso de drogas que induzem o risco de rejeição podem desenvolver danos renais, pressão alta, osteoporose, causando fraqueza dos ossos e fraturas e linfomas (tipo de câncer que afeta as células responsáveis pela imunidade).

A doença coronária ou a obstrução das coronárias por placas de colesterol é um outro problema sério que costuma surgir com o transplante. Em geral, esses pacientes manifestam dor no peito com a realização de exercícios físicos, sugerindo obstruções das artérias e sofrimento do músculo cardíaco por redução do suporte de oxigênio. Em certas situações, esse sofrimento pode ser silencioso sem nenhuma sensação de desconforto para o paciente.

O sistema imunitário de cada indivíduo tem a função de protegê-lo contra as infecções. As células com essa função circulam pelo organismo verificando a presença 
de substâncias estranhas ou diferentes das células do próprio organismo. Essas células reconhecem o coração transplantado como algo diferente do resto do corpo e iniciam uma tentativa de destruí-lo. É a rejeição. Se não houver interferência nesse processo, essas células destruirão o coração transplantado e o pulmão também, se for o caso de um transplante duplo. Para se prevenir contra a rejeição, o paciente recebe drogas imunossupressoras que atuam no sistema imunitário impedindo a destruição do novo coração. Essa rejeição pode surgir a qualquer momento e, por essa razão, o paciente recebe essas drogas no dia do transplante e manterá isso para o resto da vida (BENCHIMOL et al, 1978).

É sabido que o coração normal é um músculo forte que funciona como uma bomba de ejeção contínua. Sua função é ejetar o sangue para o sistema circulatório. $\mathrm{O}$ sistema circulatório é uma rede de tubos elásticos que permitem o sangue fluir dentro do nosso corpo. É formado pelo coração, pulmão, artérias de diferentes calibres e capilares (vasos microscópios). Esses vasos sangüíneos carregam o oxigênio e os nutrientes do sangue para todas as partes do nosso organismo.

Esse sistema inclui também veias de diferentes calibres que levam de volta o sangue já depurado de oxigênio e de seus nutrientes de volta para o coração e em seguida ao pulmão (como se fosse uma drenagem). Essa rede é tão extensa que daria duas voltas em torno da terra. A circulação do sangue traz o oxigênio e os nutrientes a todas as células, aos tecidos e aos órgãos inclusive ao próprio coração, assim como recolhe os detritos dessas mesmas células que serão filtradas nos rins, fígado e pulmões (DÉCOURT, 1945).

O funcionamento do coração é como uma bomba que bombeia o sangue para os pulmões e para outros órgãos do nosso organismo por causa de uma seqüência bem organizada de contrações das quatro câmaras. Essa seqüência é comandada por um estímulo elétrico, que se move através dos músculos por uma via nervosa. Esse estímulo nasce num conjunto de células especializadas localizadas no átrio direito (nó sinusal) e segue uma via nervosa que se bifurca posteriormente em dois ramos direito e esquerdo.

A descarga elétrica desse marca-passo natural, leva a contração seqüencial do músculo cardíaco numa freqüência natural; porém, reações emocionais e fatores hormonais podem afetar essa freqüência de descargas. Isso permite que nosso coração se adapte e responda para as variadas demandas de fluxo.

A troca de válvula aórtica é uma cirurgia cardíaca que visa à correção de uma estenose (obstrução) ou de uma insuficiência (regurgitação) do fluxo de sangue através da troca da válvula natural doentia por uma válvula artificial metálica ou biológica. A válvula aórtica situa-se entre o ventrículo esquerdo do coração e a raiz da aorta. Durante a sua abertura, o sangue bombeado pelo ventrículo atravessa a válvula em direção a aorta e os vasos periféricos. Durante seu fechamento, ela impede o refluxo desse sangue de volta para o ventrículo esquerdo (MARTINS COSTA, 1889).

Os sintomas que surgem com a disfunção da válvula aórtica são o cansaço fácil, a falta de ar, a dor no peito, as tonturas, perda de consciência, entre outros. Estes são os sintomas referidos progressivamente com a evolução da disfunção da válvula aórtica. Com a insuficiência da válvula, o refluxo de sangue para o ventrículo esquerdo obriga o coração a se desempenhar mais para bombear o sangue. Isso pode levá-lo à falência, o que se manifesta através de cansaço físico progressivo.

Quando há obstrução, o coração reage também aumentando sua força de contratilidade para vencer a resistência consumindo sua energia até a exaustão. Dores no peito, tonturas às mínimas atividades físicas e perdas de consciência representam sintomas e sinais severos de obstruções (estenose aórtica). Observe na figura 15 a valva aortica em funcionamento, aberta e fechada. 


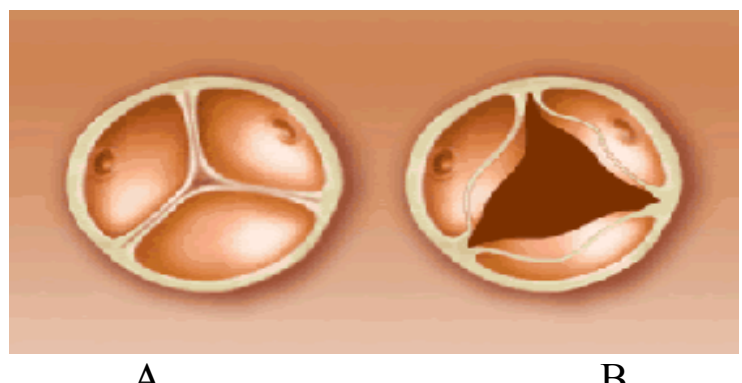

A

B

Figura 15 Valva Aortica em funcionamento (A) - fechada (B)- Aberta

Fonte Disponível em: $<$ http://www.falcettijunior.com.br Acesso em:20 dez.2003

A decisão de interferência cirúrgica é feito pelos médicos, baseado em exames de ecocardiografia e cateterismo cardíaco. Em geral, o ecocardiograma mostra dilatação importante do coração e pode ajudar na definição do grau de estenose (obstrução) ou da insuficiência (refluxo). O cateterismo cardíaco oferece informações similares acrescidas das medidas das pressões dentro do coração e na aorta e a situação das artérias coronárias. A válvula aórtica, ao contrário da válvula mitral, tem menos chances de plastias. Uma vez indicada à troca, há duas possibilidades na escolha da válvula artificial: uma prótese metálica ou uma prótese biológica.

O cirurgião tem suas preferências ligadas a fatores técnicos. Há uma grande variedade de excelentes próteses metálicas com as mesmas performances. A sua principal desvantagem é sua tendência em formar trombos ou pequenos coágulos e, se isso acontecer, sua função é comprometida exigindo sua troca. Por esse motivo, esses pacientes precisam usar anticoagulantes para sempre. Mesmo assim, sempre há um risco reduzido e definido de acontecer um derrame cerebral.

A válvula biológica também tem uma grande variedade. A maioria é de válvulas aórticas dos porcos ou retiradas de cadáveres humanos. É possível também remover a válvula da artéria pulmonar do lado direito do coração para o lado esquerdo. Sua principal vantagem é o baixo risco de se formarem trombos, causando disfunções na prótese ou derrames cerebrais. Sua principal desvantagem está na durabilidade inferior quando comparadas com as próteses metálicas. A escolha do tipo de válvula é uma decisão conjunta do cirurgião e do paciente levando em consideração tópicos como a idade, outras medicações em uso, a preferência do paciente ao uso de medicações, os riscos de uma reoperação e, ainda, o estilo de vida.

Os riscos da cirurgia são definidos individualmente, considerando a idade do paciente, as condições gerais de saúde, situações médicas específicas e principalmente o grau de comprometimento da função do coração. A recuperação é feita progressivamente, com alta prevista do hospital em 10 dias. O uso de anticoagulante é feito no mínimo de 06 semanas a 03 meses em pacientes que receberam próteses biológicas e o resto da vida para os pacientes que receberam próteses metálicas.

Após a recuperação, rara ou quase nenhuma restrição às suas atividades físicas habituais são feitas. É indicados a profilaxia com antibióticos como uma medida 
preventiva contra infecções em tratamento dentários ou potencialmente com riscos de infecção.

Para o futuro estão se realizando mudanças na legislação de atendimento médico para a cobertura dos custos elevados dos transplantes. Outras atividades, com certeza, contribuirão significativamente. Entre elas, a criação de uma estrutura de atendimento mais eficiente e campanhas de conscientização comunitária para aumentar o número de doadores; pesquisas para encontrar métodos de monitorização da rejeição dispensando a biópsia necessária e a busca de drogas imunossupressoras com menos efeito colateral.

\subsubsection{PRÓTESE VALVAL}

As próteses valvares iniciais idealizadas entre 1957 e 1965, fabricadas com tecidos sintéticos ou com polímeros plásticos flexíveis e elásticos, tiveram por modelo as próprias valvas cardíacas, algumas possuindo até mesmas cordas tendíneas (BERG et al, 1957).

São deste período as válvulas possuidoras de uma única cúspide moldada de plástico e fixada em um anel rígido de "nylon", silicone ou aço inoxidável (GOTT et al,1966), as válvulas que imitavam integralmente a valva mitral com folhetos flexíveis de "Dacron" recoberto por poliuretana e com cordas tendineas de "teflon" (BRAUNWALD et al, 1960) (MIRKOVITCH et al, 1961).

A eficiência funcional destas próteses valvares era limitada devido à baixa resistência de seus folhetos plásticos e sua elevada trombogenicidade. As primeiras válvulas implantadas em cães para resultados funcionais realmente eficientes eram válvulas de bola, idealizadas entre 1958 e 1962, caracterizadas por uma estrutura rígida de teflon ou de lucite que aprisionava uma bola lucite, de ivalon ou de aço (KERMANN et al, 1957) (SERVELL; ARBONVILLE, 1964). Note na figura 16 qual a posição correta da valva mitral. Observe na figura 17 a valva mitral em funcionamento, aberta e fechada.

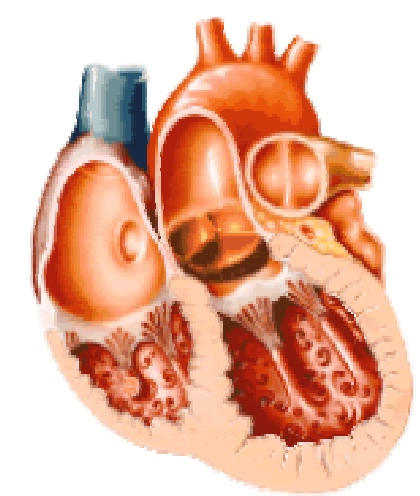

Figura 16 Posição da Valva Mitral

Fonte-Disponível em: $<$ http://www.falcettijunior.com.br Acesso em: $20 \mathrm{dez} 2003$ 


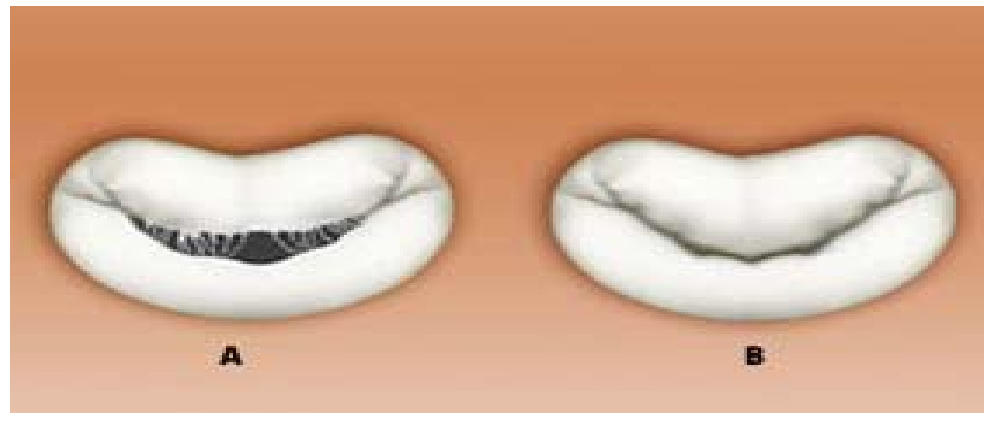

Figura 17 Valva Mitral em funcionamento (A) - Aberta (B)- Fechada

Fonte Disponível em: $<$ http://www.falcettijunior.com.br Acesso em: 20 dez. 2003

Entre estas válvulas de bola estava a primeira válvula de bola testada por Starr em 1960 constituída por uma gaiola de lucite e uma bola de silicone (STARR, 1960), válvula esta que, possuindo a gaiola de vitallium e a bola de silicone, foi utilizada para a substituição mitral e aortica de seus pacientes (SENNING,1967).

O uso clínico inicial das próteses valvares se fez por absoluta necessidade a partir de 1960. Os testes experimentais com as próteses valvares eram pouco encorajadores e não permitiam interferências sobre seu comportamento a médio e em longo prazo. Elas eram grandes, trombogênicas e seus anéis de fixação eram espessos, sempre produziam resistência ao fluxo sangüíneo e, por conseguinte, mantinham gradientes pressóricos transvalvulares elevados. Mesmo assim, válvulas de folhetos plásticos, de bola e de disco foram implantadas em pacientes cuja gravidade de suas lesões valvares, aórticas ou mitrais, impunha a indicação da troca valvar como único meio para sua sobrevivência (JATENE, 2003).

Entre 1960 e 1965, algumas próteses valvares de folhetos plásticos, ainda em teste experimental foram usadas para a substituição de valva mitral de uns poucos pacientes. Ainda no final dos anos 60 e início dos anos 70, as degenerações e roturas observadas nos homo-enxertos deram ensejo a proposições do uso de tecidos biológicos humanos ou de animais, nas quais um anel metálico ou de plástico flexível recoberto por tecido ou teflon ou dracon suporta três folhetos, semelhantes aos folhetos autógenos, homólogos ou heterólogos, a fáscia-lata, a dura-mater e o periocárdio humano ou bovino (JATENE, 2003).

Senning, em 1967, idealizou a válvula de fáscia-lata autógena fresca utilizando-a para a troca de valva aórtica o mesmo sendo feito por outros cirurgiões para as trocas aórticas e mitral (IONESCU et al, 1972), (TRIBLE, 1972).

Esta válvula de difícil modelagem, geralmente feita logo antes de sua implantação, foi logo abandonada devido à rápida e acentuada retração fibroblástica de seus folhetos (Mc ENAMY et al, 1972, TRIBLE, 1972). A válvula de dura-mater homóloga, esterelizada e conservada em glicerol, foi proposta por Zerbini e Puig, em 1971, e por eles utilizada para substituições mitrais e aórticas durante diversos anos (PUIG et al, 1975). Esta válvula resistente de baixa trombogenicidade e antigenicidade mostrou-se durável ao longo de 10 anos, quando seu índice de rotina não excedia a $2,5 \%$.

Tanto as válvulas de fáscia-lata quanto às de dura-mater, embora adequadas às trocas valvares, tal qual os homo-enxertos conservados, tiveram sua aceitação limitada 
em decorrência das dificuldades de obtenção dos tecidos biológicos e da dificuldade de suas montagens artesanais.

As válvulas de periocárdio bovino ou suíno conservadas em glutaraldeido surgiram em 1974 (IONESCU et al, 1982) Inicialmente produzidas artesanalmente, foram fabricadas por meio do curtimento e conservação, sendo largamente utilizadas até os dias atuais.

\subsection{APLICAÇAO BIOENGENHARIA NA ORTOPEDIA}

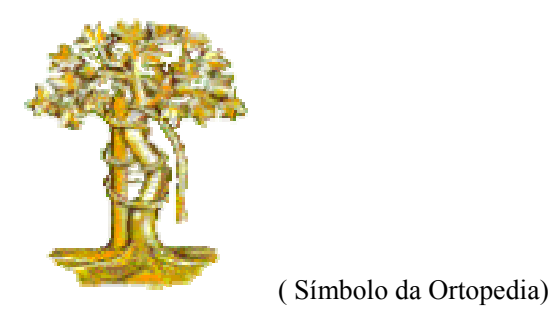

A primeira referência para a ortopedia encontrada na literatura médica data de antes do Império Brasileiro: trata-se de uma petição solicitada por um cirurgião do Rio de Janeiro - Antonio José Peixoto- ao imperador, pedindo a este permissão e ajuda para construir um instituto ortopédico (CAMARGO et al, 1952).

Imperador Pedro II enviou esse requerimento para a Academia Imperial de Medicina, que era sua "conselheira" no que dizia respeito às questões médicas. Transcrita nos anais da academia está a resposta dada por Nunes Garcia, renomado professor de anatomia da Faculdade de Medicina do Rio de Janeiro. Nunes pensava que a Ortopedia deveria ser considerada separadamente da escola médica em si, para que, como ele explicou, a ginástica pudesse ser ensinadas no Collegio Pedro II e a Ortopedia pudesse ser ensinada na Clinica da Faculdade de Medicina; o professor providenciou, assim, a disponibilidade do equipamento necessário (ABREU, 1950).

Este documento demonstra, por conseguinte, que no início de 1841 a Faculdade de Medicina já estava pedindo ao governo alguns equipamentos auxiliares no ensino da Ortopedia. Parece inacreditável, todavia, que, somente 70 anos após - em 1911 - o pedido de Nunes Garcia tenha sido atendido, no momento em que o ensino dessa especialidade estava oficialmente estabelecido no Rio de Janeiro. A história dos implantes metálicos - quando foi necessário substituir ossos inteiros ou articulações nos seres humanos - começa por volta de 1565, quando Petronius utilizou uma placa de ouro para restaurar um maxilar. Hieronymus Fabricius utiliza, uma placa de ouro e cobre numa liga para fios de sutura (ABREU; RÜCKER, 1950).

A Ortopedia brasileira começou a se desenvolver no final do século XIX. Antes disso, os casos ortopédicos eram encaminhados a clínicos gerais e a pediatras, que acabaram atraindo para si considerável reputação. O Barão Afonso de Carvalho configura-se como excelente exemplo, uma vez que realizou osteoclases ${ }^{39}$, osteotomias ${ }^{40}$, e outras

\footnotetext{
${ }^{39}$ Osteoclasse: operação que consiste em quebrar um osso com fins ortopédicos

${ }^{40}$ Osteotomia:secção cirúrgica de um osso
} 
cirurgias ortopédicas, ficando conhecido pela sua perspicácia em Traumatologia (MARCZYK, 2002).

Em 1888, o Ministro da Educação, Visconde de Saboya, constituiu a Cadeira da Cirurgia Pediátrica, que foi presidida por Candido Barata Ribeiro - um brilhante e talentoso cirurgião que se dedicou à Ortopedia com o mesmo entusiasmo que demonstrou em sua vida pública: foi prefeito do Rio de Janeiro, senador e juiz da Suprema Corte. Barata Ribeiro revelou, ainda, interesse particular no tratamento do "pé torto" 41 e da tuberculose articular e óssea. Alguns de seus artigos eram extremamente avançados para a época (WERTHEIMER, 1952).

Joaquim Pinto Portella, ortopedista estudou na Europa, escreveu Impressões de uma viagem à Itália e França debaixo do ponto de vista da Moderna Ortopedia, em 1888, escreveu um artigo que se caracteriza por descrever seu plano para o desenvolvimento da ortopedia no Rio de Janeiro. Não demorou muito tempo para que seus ideais dessem fruto e isso se comprova pela fundação de um hospital ortopédico. Em 1898, Ribeiro escreveu um livro sobre a correção eficaz da cifose. Cirurgiões menos habilidosos induziram o abandono deste método, tencionando enfatizar a importância das possibilidades de correção progressiva da deformidade, um dos conceitos básicos do tratamento ortopédico (CAMARGO et al, 1952).

Pode-se definir a ortopedia do presente como aquele ramo da cirurgia que trata das moléstias e traumatismos, ma formações e deformações do aparelho motor e osteoarticular. É uma cirurgia eminentemente reconstrutiva e as razões de ordem social se integram cada vez mais no círculo das suas cogitações (MOREIRA, 1939).

A esta ciência competem os múltiplos problemas sociais dos acidentados em geral e dos acidentados de trabalho, tratando, mais especificamente, das incapacidades resultantes e de suas influências sobre a vida econômica da coletividade, defendendo esta dos altos índices dos traumatismos, cada vez mais multiplicados pelos meios modernos de transporte e de trabalho (MOREIRA, 1939).

Em princípio, exclusivamente conservadora, a ortopedia aproveitou-se largamente dos recursos da cirurgia asséptica e chegou a ser erroneamente definida como cirurgia osteo-articular no sentido sangrento (MOREIRA, 1937). É interessante lembrar que a ortopedia brasileira foi dominada por influências européias, particularmente pela França, onde as instituições de ensino eram organizadas como as da França, onde não havia lugar para cuidar de adultos com necessidades ortopédicas.(todo o procedimento do tratamento aplicado no paciente seguia métodos vindos da França) (SEVCENCKO, 1985).

Como se sabe, os hospitais brasileiros, em geral, eram direcionados somente a crianças e adolescentes. Muitos anos se passaram até que a Traumatologia e a Ortopedia se associassem, no Brasil, sem se preocupar com a idade do paciente. Dessa maneira, pacientes adultos com necessidades ortopédicas, como fraturas, eram tratados nas repartições de cirurgia geral ou em hospitais infantis. Gradualmente, todavia, a carência de aparelhagem e de pessoal treinado ocasionou a criação de seções ortopédicas nos hospitais, de uma maneira geral. É importante salientar que as doenças mais comuns nesta área eram a poliomielite, as doenças defeituosas e encefalopatias. Por conseguinte, o crescimento dessa especialidade no Brasil possibilitou que muitos hospitais, tanto os do governo como os particulares, fossem construídos exclusivamente para a dedicação ortopédica e traumatológica dos pacientes. São Paulo e Rio de Janeiro lideraram a nova tendência. Hoje, muitos destes serviços estão espalhados pelo país com departamentos especializados em inúmeros hospitais (CAMARGO et al, 1952).

\footnotetext{
${ }^{41}$ Pé-torto: deformidade do pé que impede o apoio sobre o calcâneo.
} 
Em 1804, Bell menciona em seu livro a utilização de agulhas fabricadas de ouro e prata. Gurgel, em 1876 com notável habilidade como professor, alcançou fama na América latina. Deixou várias publicações sobre poliomielite, doenças defeituosas, encefalopatias. $\mathrm{O}$ início do século XX pode ser considerado um marco decisivo para a Ortopedia: a descoberta do raio-X assinalou o começo dos anos 1900 e a própria ortopedia apenas começava a ser vista como uma especialidade autônoma (CAMPOS, 1950).

Os britânicos ainda dominavam o desenvolvimento da Ortopedia, mas o "novo mundo" (América do Sul) estava adquirindo maturidade e estava, progressivamente, aumentando as contribuições feitas pelos americanos. A virada do século foi marcada por novas instituições e associações que buscaram destacar a Cirurgia Ortopédica como uma especialidade individual e crescente.

Deve-se lembrar que, nesta época, a necrose óssea era bastante freqüente, pois não havia antibiótico e, desse modo, qualquer estudo a respeito de necrose óssea não infecciosa era inovador (SARDINHA et al, 1948).

Com o desenvolvimento e a pesquisa surgem outros tipos de ligas metálicas a base de: ouro e cobre; alumínio, prata, entre outras, no período que vai de 1894 a 1900. Johann, estudioso da Ortopedia, realizou vinte e uma cirurgias de fêmur, utilizando cravos trilaminar e obteve excelentes resultados. Outros nomes foram se destacando, como Lambotte em 1907, Schone em 1913, entre outros que utilizaram, principalmente, parafusos de prata rígidos, utilizados em fraturas de antebraço, Axhausen-1910 a necrose acontece nas extremidades ósseas de qualquer fratura e isto estimula a proliferação periostal que substitui a lesão. Ele também acreditava que a necrose focal de osso subcondral causava mudanças na cartilagem de articular, ocasionando a "artrite deformante" (AXHAUSEN, 2002).

No Brasil, a criação de dois departamentos foram possíveis através das idéias de Portella. O primeiro foi fundado em 1911: um departamento na Santa Casa bem adaptado para o ensino; o segundo, no Hospital São Zacarias, em 1914, bem equipado com 150 leitos para crianças com menos de 14 anos, uma boa sala de operação e uma sala de curativos. Na Universidade do Rio de Janeiro, em 1911, a Cadeira de Pediatria Médica e Cirúrgica foi dividida em duas novas Cadeiras: Clinica Pediátrica Médica e Clinica Pediátrica Cirúrgica e Ortopedia (NAPOLI, 2001).

Deve-se dizer que, curiosamente, a guerra sempre desempenhou um papel importante na história da ortopedia, pois muitos dos colaboradores foram cirurgiões militares. É interessante notar que muitas das realizações durante e depois de Primeira Guerra (1914-1918) não estavam diretamente relacionadas a danos traumáticos recebidos a guerra (causados em conseqüência da guerra) Dessa maneira, a Guerra Mundial de 1914 consolidou, definitivamente, o prestígio da cirurgia ortopédica: as mortíferas armas modernas inundaram os hospitais de mutilados e feridos de toda espécie (MOREIRA, 1939). Dois fatos se tornaram evidentes: primeiro, que a grande maioria dos feridos de guerra era do aparelho locomotor, amputado de braços ou pernas; segundo, que os ortopedistas, pela natureza das suas atividades anteriores e pelos múltiplos recursos técnicos de que dispunham, assim como pela formação e características de seu espírito clínico e métodos de trabalho, eram os mais indicados para o tratamento desses feridos (ABREU, 1950).

Um médico militar belga Mathysen introduziu o emprego das ataduras gessadas, que se tornaram desde então um dos mais preciosos auxiliares da técnica ortopédica (MOREIRA, 1939). Faz-se interessante salientar que, por muitos anos ainda, a ortopedia continuou a ocupar-se exclusivamente das malformações congênitas, dos pés tortos e das paralisias. O tratamento destas consistia exclusivamente na aplicação de 
aparelhos, meios fisioterápicos e ginásticas corretivas; raramente se observava alguma tenotomia $^{42}$ : no tocante as fraturas, o especialista nunca se ocupa das recentes, recebendo apenas as mal consolidadas cujas conseqüências devia minorar se fosse fratura mal consolidada antiga era melhor para ser trabalhada, pois as recentes poderiam ser curadas (PUECH,1937; ZANDER, 1940).

O problema das amputações sofreu completa revisão para a qual o especialista em amputações o cirurgião ortopédico trouxe uma contribuição preponderante. Responsável pelo aparelhamento ulterior dos mutilados, desde logo observou numerosos tipos de amputação que constituíam virtuosismos operatórios e demonstrações brilhantes de técnica cirúrgica redundavam, na prática, em verdadeiros desastres, quando a função das partes sacrificadas devia ser substituída pelas próteses mecânicas (MOREIRA, 1939). Trazendo sugestões ao cirurgião geral, o ortopedista o foi convencendo de que, nem sempre a amputação mais econômica era a melhor e de que certos segmentos, se conservados, constituiriam verdadeiros empecilhos, havendo, portanto conveniência em sacrificá-los de inicio. O mesmo se deu com o tratamento das fraturas (MOREIRA, 1939). Logo, aos poucos, a realidade foi demonstrando que, embora tratados com meios mais modestos e menos cirúrgicos, os resultados finais eram superiores quando se entregavam esses feridos aos hospitais ortopédicos (SOUZA, 1950).

Terminada a I Guerra Mundial, em 1918, a ortopedia apurando e ampliando a sua enorme experiência no tratamento dos traumatizados, conservou esta nova conquista com uma posse justa e duramente adquirida. A cirurgia com certa relutância foi cedendo a este seu ramo absorvente, porque cheio de vitalidade, o terreno da Traumatologia por ela um tanto negligenciado; e a Ortopedia se tem mostrado digna de cultivá-lo e fertilizá-lo (MOREIRA, 1939). Portanto, gradualmente, a cirurgia ortopédica foi delineando o seu campo de ação e, passada a adolescência, fixou os traços que lhe deram a sua personalidade atual. Longe vão, pois, os tempos em que ela necessitava justificar a sua existência e definir os seus limites (NAPOLI, 2001).

Não se pode esquecer a importância da penicilina - cujos efeitos foram descoberto por Sir Alexander Flemming, em 1929. Os alemães precisavam de medidas rápidas para recolocar os seus soldados em condições de luta e desenvolveram vários procedimentos de fixação de fraturas durante este período. $\mathrm{O}$ conhecimento adquirido com as lutas da Primeira Guerra ajudou no tratamento das vítimas da Segunda Guerra Mundial (1939-1945). Nesta houve menos amputações executadas, menos gangrena e melhores meios de fixação das fraturas (NAPOLI, 2001).

Nos anos que se seguiam à guerra, os cirurgiões ortopédicos buscaram aperfeiçoar o tratamento das fraturas, em particular com o uso de pinos metálicos e arames para fixação. Muitos foram os fundadores da cirurgia ortopédica moderna: França: Dupuytren, Malgaine, Menard, Broca e Kirmisson; Estados Unidos: Davis, Schaffer, Taylor, Sayre, Lovett, Abbot e Bradford; Inglaterra: Pott, Little, Thomas e Robert Jones; Itália: Panzeri, Rizzoli e Codivilla; Alemanha e Austria: Nicoladoni, Albert, Hoffa, Biesalski, Vulpius, Schulze, Blencke e Hessing; Brasil: Barata Ribeiro como um dos precursores da Ortopedia brasileira (BATALHA et al [ 19...? ]).

É importante ressaltar que a ortopedia recebeu da cirurgia princípios gerais, bem como métodos de investigação e trabalho; dessa forma, mais ou menos, os primeiros cultores da ortopedia, quase todos os cirurgiões, restringiram voluntariamente aquele vasto campo de atividade para limitar-se à prática da cirurgia ortopédica, ganhando em profundidade e precisão o que perdiam em extensão (MOREIRA, 1939) o que eles ganhavam em precisão nas cirurgias perdiam em quantia de pessoa.

\footnotetext{
42 tenotomia: cirurgia curta duração, onde é realizado cortes no tendão que promovem seu alongamento.
} 
Por outro lado, a ciência estudada aqui desenvolveu largamente ao tronco comum os talentos que havia recebido, rasgando novos horizontes, exigindo novos tratamentos até então inexistentes os quais, como no caso da luxação congênita coxofemural resgatam anualmente milhares de seres destinados antes, à mutilação e à invalidez (BITTAR, 1950).

Inicialmente preocupada somente com a forma, a ortopedia não tardou em reconhecer a sua verdadeira finalidade: a função. Forma e função, eis os dois lemas que a dirigem. Hoje se deveria dizer função e forma, pois, pelo seu critério, a função prima sobre a forma e, se o ideal de conservá-las ou restituí-las, a ambas, não puder ser atingido, a forma deve ser sacrificada em proveito da função (MOREIRA, 1939).

Uma vez que os metais nobres como o ouro e a prata eram muito caros e, em razão disso, pouco viáveis, em 1920, começa a difundir-se o uso do aço. O primeiro aço usado foi o ferro-cromo, sendo utilizado também para implantes nos instrumentos cirúrgicos. Entretanto, como, em sua maioria, eram soldados, em poucas semanas começavam a aparecer zonas de oxidação, devido a eletrolize e corrosão intergranular (BAUMER, 2002).

Rezende Puech - professor da USP eleito para a Cadeira da Clínica Cirúrgica Infantil e Ortopédica - construiu, em 1925, um considerável prestígio, um hospital bem equipado: o Pavilhão Fernandinho Simonsen, no térreo da Santa Casa; organizou e planejou, ainda, o ensino da Ortopedia, de acordo com as idéias mais avançadas para a época. Devido às regras especiais do hospital, os equipamentos foram somente disponibilizados para crianças até 15 anos. Somente em 1925, quando a cadeira da Clínica Cirúrgica Infantil e Ortopedia da Universidade de São Paulo foi convertida em Clínica Ortopédica e Traumatológica, os equipamentos hospitalares da Clínica foram reservados para o tratamento de crianças e adultos de ambos os sexos (NAPOLI, 2001).

O Brasil conta com as Universidades em São Paulo, Recife (Pernambuco), Bahia (Salvador) Rio de Janeiro; cada universidade se tornou um centro ortopédico, estimulando um maior desenvolvimento da especialidade por meio de métodos didáticos que compensassem a falta de equipamento hospitalar adequado (CAMARGO e WERTHEIMER,1952). Na Universidade do Recife, parte nordestina do Brasil, em 1925, Barros Lima assumiu a Cadeira da Ortopedia, tornando a universidade um importante centro de aprendizagem e contribuindo significativamente, pois, para transformar a Ortopedia em uma especialidade bem conhecida e aceita em uma grande área do território brasileiro (CAMARGO e WERTHEIMER,1952). Achilles de Araujo, professor de Ortopedia e Traumatologia da Faculdade de Ciências Médicas do Rio de Janeiro, também favoreceu muito essa ciência fundando, em 1930, a Clínica Ortopédica do Hospital Evangélico, que contava com um departamento bem equipado para crianças e adultos(CAMARGO et al, 1952).

Em São Paulo, nesse período, foi construído, sob a supervisão de Rezende Puech, o Pavilhão Fernandinho Simonsen e foi acabado, em 1931, um hospital com 150 leitos para pacientes com idade máxima de 15 anos. Este hospital apresentava um andar cirúrgico, departamento com raio-X, uma loja de ferramentas ortopédicas, sala de palestras e de aula e, ainda, modernos equipamentos para cirurgias ortopédicas e pediátricas (CAMARGO e WERTHEIMER,1952). Observe na figura 18, a obra deste Pavilhão Fernandinho, sua beleza e o orgulho que trouxe para a cidade na época. Em São Paulo foi organizado também o serviço de Ortopedia do Hospital Municipal, chefiado por Orlando Pinto de Souza e também o Hospital da Cruz Vermelha, sob a direção de Azzi Leal ( NAPOLI,2001). 


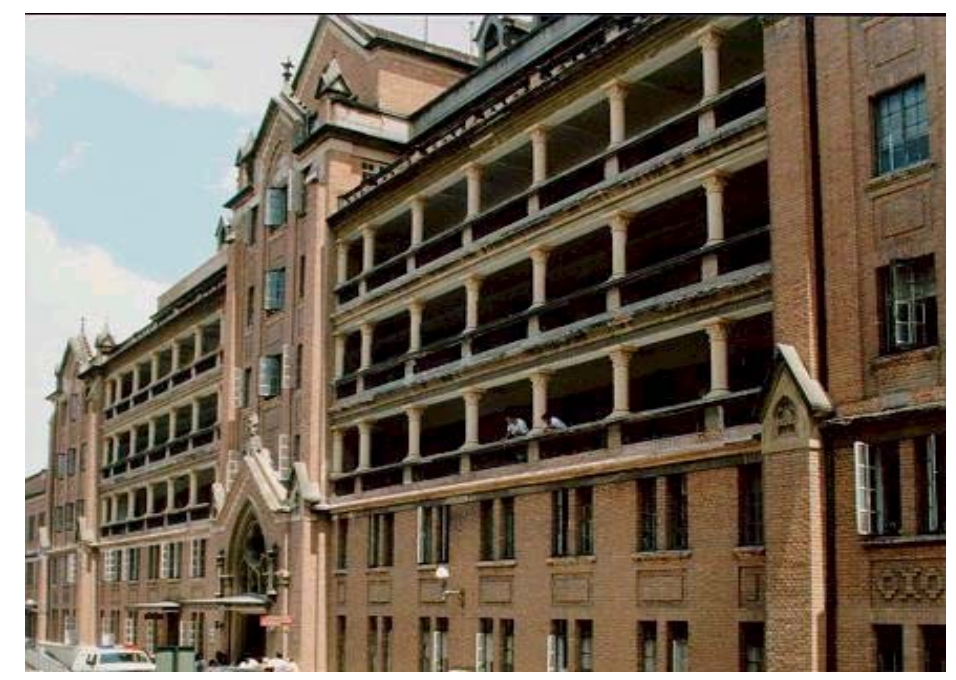

Figura 18 Pavilhão Fernandinho Simonsen em São Paulo

Fonte-Disponível em: $<$ http://www.santacasasp.org.br Acesso em: $20 \mathrm{dez} 2003$

É preciso citar a Santa Casa de Santos - SP, que possui cinqüenta leitos e um serviço muito ativo em acidentes. Foi chefiada por Emilio Navajas. Tem escola para crianças defeituosas e incapacitadas, a única do tipo no Brasil (CAMARGO e WERTHEIMER,1952). No Rio de Janeiro foi construído O Pavilhão de Ortopedia e Traumatologia, uma divisão do Hospital São Francisco de Assis, estruturado por Achilles de Araujo, com capacidade para cinqüenta leitos para crianças e adultos, salas cirúrgicas, salas de aula, departamento de raio-X e de fisioterapia, uma biblioteca e um ambulatório. Ainda no Rio de Janeiro, há o Pavilhão Dodsworth, que se trata de um hospital com trinta leitos, dedicados ao tratamento de tuberculose osteo-articular dirigido por Dagmar Chaves. Em São Paulo, em 1934, Godoy Moreira fundou o Instituto Ortopédico e Clinica de Fraturas, um hospital com 40 leitos, reservado exclusivamente para a especialidade (CAMARGO et al, 1952).

Vale salientar que a clínica localizada no Centro Médico da faculdade de medicina da Universidade de São Paulo é a única escola médica da América Latina que recebeu conceito "A" atribuído pela Associação Médica Americana - American Medical Association, no início dos anos 50. Possui bons equipamentos laboratoriais, especialmente no departamento de anatomia. O banco ósseo é usado extensivamente. Esta clínica têm auxiliares cirúrgicos e cirurgiões de plantão 24 horas por dia para cuidar de casos de emergência (NAPOLI, 2001).

Barbosa Vianna - fundador do Colégio Brasileiro dos Cirurgiões - foi, em 1935, convidado especial para uma série de palestras na Universidade de Paris. Os principais assuntos abordados nessas conferências foram a escoliose congênita, a doença de Madelung, amputação de próteses e, ainda, o tratamento de pé torto. Puech, Achiles de Araujo, Barros de Lima e um grupo de outros ortopedistas entusiásticos planejaram e fundaram a SBOT - Sociedade Brasileira de Ortopedia e Traumatologia de São Paulo, tendo como Presidente, em 1935 Rezende Puech (CAMARGO e 
WERTHEIMER,1952). A SBOT foi a primeira sociedade brasileira a ser fundada na América Latina. Seus objetivos eram: organizar os cirurgiões brasileiros especializados em Ortopedia e proteger e assegurar o prestigio deste ramo da cirurgia; almejava também um maior adiantamento, além de encorajar o estudo e a prática da especialidade; e, finalmente, desejavam ajudar na solução de problemas médico-sociais ligados à cirurgia ortopédica (FRASCÁ, 1940).

A fim de estimular o estudo e a pesquisa, a SBOT instituiu prêmios bienais para as melhores contribuições nacionais para a Ortopedia e Traumatologia. As atividades constituíram, sem dúvida, uma força para o progresso da Ortopedia Brasileira e um intermédio para um melhor entendimento entre os especialistas.

Faz-se importante acrescentar que o crescimento da cirurgia ortopédica brasileira tem estado intimamente associado ao crescimento dos centros de ensino médico. Assim, em todas as escolas de medicina do Brasil são ensinadas oficialmente a Clínica Cirúrgica Infantil e Ortopédica, exceto a Universidade de São Paulo e da Faculdade de Ciências Médicas do Rio de Janeiro, Clinica Ortopédica e Traumatológica.

No III Encontro da Sociedade Brasileira de Ortopedia e Traumatologia, Godoy Moreira e Barros Lima apresentaram um artigo sobre o tratamento de suas seqüelas Godoy Moreira, em 1937 desenvolveu estudos feitos sobre o tratamento de fraturas do pescoço femoral, usando um parafuso especial para a osteossíntese. A trefina de Godoy Moreira é um instrumento útil para a biópsia óssea. $\mathrm{O}$ mesmo autor e colaboradores desenvolveram um conjunto de instrumentos e uma técnica para enxerto ósseo, particularmente para aquele do tipo conhecido como bicondilar ${ }^{43}$. Dos mesmos autores instrumento para fixação do colo femoral na osteossíntese para fratura do pescoço femoral (CAMARGO e WERTHEIMER, 1952) Godoy Moreira, em 1938 apresentou um parafuso helicoidal do tipo empregado no tornozelo, porém mais alto e mais cortante e que toma ponto de apoio exclusivamente na cabeça do fêmur, criando algo inteiramente novo; além disso, o parafuso era perfurado para permitir a sua introdução, guiado pelo fio de Kirschner, o que supriu a principal objeção contra o emprego do parafuso, que era justamente a dificuldade da sua introdução exatamente no centro do colo. A técnica permite fazer a osteossíntese ${ }^{44}$ por meio de uma pequena incisão sob anestesia local e sem absolutamente nenhum traumatismo. Apresentando, assim, uma execução perfeitamente segura, a técnica consiste em reduzir a fratura, diminuir o número de raio-X e eliminar o gesso após a cirurgia. Desse modo, a recuperação é rápida, permitindo que o paciente ande no nono dia após a cirurgia (MOREIRA et al, 1949).

Barros Lima fundou, no Recife, em 1938, o primeiro hospital brasileiro para cuidar da tuberculose osteo-articular: o Sanatório Infantil para Tuberculose Cirúrgica. Também fundou os Arquivos Brasileiros de Cirurgia e Ortopedia, uma revisão da especialidade, que ele próprio editou e na qual publicou a maioria de seus numerosos artigos. Barros Lima realizou notáveis trabalhos: a propósito do tratamento das fraturas do antebraço nas crianças, Tracion com hilos em las fraturas de femur de los ninos ( traduzidos para o espanhol e francês), Epifisile deformante da tíbia, Neurofibromatose cutânea óssea, Gibosidade por tétano, a propósito da gênese da luxação coxo-femural, Tratamento da paralisia obstétrica, e um livro; Tratamentos Cirurgicos da Tuberculose Óssea, publicado em 1931 (LIMA,1931).

Em 1939, é fundada, por Achilles de Araújo, a Revista Brasileira de Ortopedia e Traumatologia, na qual se publicaram diversos trabalhos. A Sociedade Brasileira de

\footnotetext{
${ }^{43}$ bicondilar: saliência de um osso, arredondado de um lado e achatado fo outro

44 osteossíntese: junção dos fragmentos ósseos nas fraturas.
} 
Ortopedia e Traumatologia foi fundada em 1940, por Domingos Define e quando a nova escola médica, a Escola Paulista de Medicina, foi criada em 1933, Nova escola médica, Domingos Define, tornou-se professor de Ortopedia publicou estudos sobre: o novo processo para estabilizar a articulação tíbio-tarsica no pé paralítico; a preluxação do quadril; novas aquisições no terreno do tratamento das osteomielites; traumatismos obstétricos da região escápulo-humeral; etiopatogenia da coxa-plana; estudo experimental; fratura do colo de fêmur; considerações sobre alguns casos de lesão da fibrocartilagem do joelho; novo modelo de mesa destinada ao tratamento das fraturas da coluna vertebral; tratamento das pseudoartroses congênitas dos ossos da perna, entre outros (DEFINE, 1938, 1940,1942).

Godoy Moreira, em 1940, tornou-se professor, começou a ensinar a ortopedia em um departamento da Santa Casa, enquanto esperava os novos equipamentos do Hospital das Clinicas, que estava sendo construído. No Rio de Janeiro, existia em 1948 duas escolas nas quais a ortopedia e traumatologia erão ensinadas: Escola Nacional de Educação Física, cadeira de Traumatologia ocupada por Caio do Amaral e Faculdade de Ciências Médicas, cadeira Clínica Cirúrgica Infantil e Ortopédica ocupada por Dagmar Chaves (CHAVES, 1948).

Em 1942, Godoy foi eleito Diretor clinico do Hospital das Clinicas e organizou o departamento de Ortopedia e Traumatologia, convencendo o Governo a usar os equipamentos do Hospital a fim de cuidar dos casos de emergência da cidade de São Paulo.Assim, o Hospital das Clínicas e a Escola de Medicina de São Paulo recebem um vasto material de ensino para todas as clinicas. Dentre os trabalhos de Godoy Moreira, menção especial deve ser feita a suas pesquisas sobre fraturas do colo femoral e suas contribuições para a técnica de enxerto ósseo. Outra contribuição foi, sem dúvida, a trefina usada para biópsia de tumores ósseos profundos (MOREIRA et al, 1948).

O laboratório de Biomecânica integra o conjunto dos laboratórios de investigação médica - LIM, da Faculdade de Medicina da USP. O LIM-41 foi criado com a finalidade de apoio ao ensino e pesquisa, à oficina Ortopédica do Depto de Ortopedia e Traumatologia, à Industria na normatização e estudo de materiais de implante e para transferência de tecnologia à indústria. Seu planejamento e instalação foram executados pelo Prof. Dr. João Delfino Michaelson Bernardo de Alvarenga Rossi e engenheiros mecânicos Marco Antonio Nigro e Tomaz Puga Leivas (NAPOLI, 1991).

Instituído em 1978, inicialmente localizado no 3o andar do prédio da Faculdade de Medicina da USP, mudou-se para área situada no subsolo do edifício do Instituto de Ortopedia e Traumatologia. Em virtude das dificuldades encontradas, a partir de sua instituição até a mudança para as novas instalações, os equipamentos recebidos, em sua maioria, foram construídos através de recursos técnicos e financeiros próprios do Instituto de Ortopedia e Traumatologia (NAPOLI, 1991).

No final de 1984, foi assinado convênio com a FINEP, o que proporcionou a compra de moderna aparelhagem adequada às pesquisas da mecânica do aparelho locomotor. Equipado com: uma máquina universal de testes com capacidade de até 5 toneladas com plotter(x-y) para acompanhamento das provas; um tensímetro elétrico (strain-gage) com capacidade de leitura de até 10 canais simultâneos; uma lupa até 200 aumentos, própria para metalurgia, associada a aparelhagem para confecção de corpos de prova; um durômetro aferido em unidades Brinell, Rockwell e Vickers; aparelho de fotoelasticidade destinado a estudos qualitativo e quantitativo de tensões e que permite a interpretação de modelos planos e em terceira dimensão, acoplado com aparelhagem fotográfica; um equipamento de televisão para o estudo dos movimentos articulares de marcha; um microcomputador com monitor, drive e impressora; um aparelho de raio-X marca Westhinghouse portátil de $35 \mathrm{~mA}$ e $90 \mathrm{Kv}$, para radiografias de peças anatômicas; 
um torno mecânico com barramento de $80 \mathrm{~cm}$ e placa de 4 castanhas, para confecção de corpos de provas; balanças de precisão, micrômetros, paquímetros e relógios Comparadores; um congelador; componentes de pequena oficina mecânica de apoio e biblioteca especializada (NAPOLI, 1991).

Foi inicialmente inaugurado em 24 de abril de 1986 pelo Governador do Estado, Orestes Quércia. As principais linhas de pesquisa são: especificação do osso como material e simplificação de material de implante (NAPOLI, 2002).

Entre suas publicações Princípios Fundamentais do tratamento da paralisia Infantil; Indicações dos transplantes ósseos em cirurgia ortopédica; Tratamento da pseudo-artrose do colo do fêmur pela osteosíntese: Tratamento das fraturas e pseudoatroses do colo do fêmur pela associação dos enxertos ósseos esponjosos e corticais; enxerto bicondiliano; fixação da cabeça femoral na osteosíntese do colo do fêmur; técnica e aparelhagem; seqüelas da paralisia Infantil; Contribucion al estúdio del sindrome de Volkmann; Anca e scatto; La disostose cleido-cranica come malattia ereditaria; e Luxations habituelles de la rotule (CAMARGO e WERTHEIMER,1952). Além disso, Godoy e colaboradores desenvolveram um instrumento para a fixação do colo femoral na osteossíntese para fratura do pescoço femoral (MOREIRA, 1938,1939,1946).

Também em 1942, Austin T. Moore, um médico americano, executou e noticiou a primeira substituição de quadril por uma prótese metálica. Pela primeira vez, ele tinha substituído a porção superior inteira do fêmur com uma prótese de vitallium. Tinha cabeça redonda, laçada por inserção de músculos, e uma extremidade inferior que deslizava para o interior da diáfise fixando-se a ela.Com o passar dos anos, melhorou o desenho da prótese e a técnica cirúrgica. Em conseqüência, há um tipo de prótese chamado Austin-Moore, que ainda hoje é utilizado (AXHAUSEN, 2002).

A introdução de ligas que poderiam ser efetivamente usadas favoreceu também uma nova onda de próteses que foram desenvolvidas para o tratamento tanto da artrite como de fraturas problemáticas. Faz-se interessante salientar que o uso dos antibióticos e de novos diagnósticos também facilitou a prática ortopédica. Em 1944, a Cadeira da Clinica Cirúrgica Infantil e Ortopedia da USP foi convertida na Clinica Ortopédica e Traumatológica. Os equipamentos hospitalares da clínica foram, então, estipulados para tratar de crianças e adultos de ambos os sexos.

A cidade de São Paulo, graças à industrialização, em 1944, logo viu os seus hospitais inundados de acidentados. O super fluxo de pacientes nos corredores tornou-se uma cena comum, e um hospital novo e maior fez-se, pois, necessário.Um novo hospital foi construído, hospedando a Clinica e Traumatologia e caracterizando-se como um dos mais modernos e bem equipados do mundo. Godoy Moreira, em Janeiro de 1946, fundou a Revista do Hospital das Clínicas, onde a maioria dos artigos da Clínica Ortopédica e Traumatológica está publicada (Leivas, 2001).

Como se sabe, contribuições feitas por especialistas brasileiros à literatura da cirurgia ortopédica e de trauma foram inúmeras e satisfatórias. Em razão disso, vale ressaltar algumas delas. Domingos Define: Novo processo para estabilizar a articulação tibio-tarsica no pé paralitico; A preluxão do quadril; Novas aquisições no terreno do tratamento das osteomielites; Traumatismos obstétricos da região escapulo-humeral; Etiopatogenia da coxa-plana. Estudo experimental; Fratura do colo do fêmur; Considerações sobre alguns casos de lesão da fibrocartilagem do joelho; Novo modelo de mesa destinada ao tratamento das fraturas da coluna vertebral; Tratamento das pseudoartroses congênitas dos ossos da perna publicou em 1933. Desenhou, ainda, um modelo de uma mesa para o tratamento das fraturas de coluna e também desenvolveu a 
técnica para a estabilização da articulação do tornozelo no pé paralítico (DEFINE, 1937,1938,1944).

Dando continuidade à lista de especialistas que colaboraram para o desenvolvimento da ortopedia e da traumatologia, vem Rezendo Puech, médico que desenvolveu um procedimento cirúrgico para o tratamento do Pé Torto Congênito. Milton Weinberger fez uma contribuição valiosa para a tração dos dedos da mão, usando um aparelho especial, o qual foi adotado por Albee em sua mesa de fratura. Flávio Pires de Camargo desenvolveu uma nova técnica para fraturas da extremidade distal do fêmur; estudou, a técnica de osteossíntese intramedular na Clínica Ortopédica e Traumatologica de São Paulo. Em São Paulo, Edmundo Batalha estudou a anestesia por resfriamento e a técnica de enxerto ósseo. Luiz Gustavo Wertheimer fez estudos originais sobre a inervação das articulações. É importante mencionar, finalmente, Lauro Barros de Abreu, que desenvolveu uma linguagem de sinais cirúrgicos padronizados, que inclui a maioria dos instrumentos usados na cirurgia ortopédica; tal padronizaçao constitui em uma técnica para pedir a instrumentação durante a operação, utilizando sinais especiais das mãos (CAMARGO; WERTHEIMER, 1952).

Adentrando no campo das técnicas roentgenográficas como aplicadas ao sistema locomotor, dois trabalhos merecem ser mencionados: um deles, realizado por Jany e Moretzsohn de Castro, que desenvolveram uma técnica prática de Cineroentgenografia para todas as partes móveis do corpo humano. Fotografando a imagem sobre a tela fluorescente especial, usando filme hipersensibilizado com vapor de mercúrio, os pesquisadores conseguiram excelentes imagens do movimento dos órgãos em qualquer distância do filme ao alvo, em uma sala iluminada e com controle remoto. Isto abrirá um imenso campo nos estudos da cinética. Este instrumento está sendo fabricado na Inglaterra, atualmente. Geraldo Guerreiro, por sua vez, desenvolveu uma técnica para exposições laterais lentas da coluna torácica com a respiração do paciente. Isto apaga as sombras das costelas, resultando, assim, em imagens claras da vértebra. Vale dizer que todas as produções científicas dos cirurgiões ortopédicos e traumatologistas brasileiros foram publicadas quase que totalmente em três pesquisas médicas:

Revista do Hospital das Clínicas de São Paulo, Revista Brasileira de Ortopedia e Traumatologia Rio de Janeiro e Arquivos Brasileiros de Cirurgia e Ortopedia (Recife, Pernambuco) (JANY; MORETZSOH, 1942, 1943,1947). Estas eram as únicas fontes de publicações para a ortopedia no Brasil. Para que os médicos pudessem saber o que estava acontecendo na ortopedia em diversos estados brasileiros.

Nas fraturas de perna utilizou-se a fixação bipolar com fios de Kirschner foi o procedimento escolhido para o estudo de pacientes tratados na Clínica Ortopédica e Traumatologica da Universidade de São Paulo. Em relação às fraturas na articulação do tornozelo, existem contribuições valiosas de Pinto de Souza e Bruno Maia. Fraturas ósseas de pé foram estudadas por Blessmann e Salles. Para as Fraturas de mão indicamse os artigos de Souza Ramos e Wertheimer e seus colaboradores. Lesões traumáticas de punho, artigos de Achilles de Araujo. E as comunicações de Morães sobre estioloidite do rádio (BLESSMAN, 1946; SOUZA, 1939).

No Brasil alguns assuntos - entre eles, as anomalias e a má formação congênita - foram particularmente bem estudados. Dentre as inúmeras publicações sobre o assunto, deve-se citar aquelas que lidam com luxação congênita da articulação do quadril, no Brasil, como enfatizou. Puech, não representa o mesmo problema para alguns países europeus. No Brasil, sua incidência é maior entre as raças estrangeiras que moraram por algum tempo em nosso país, como, por exemplo, os japoneses. O pé torto congênito e seu tratamento são, de longa data, um assunto de interesse. Dentre as 
publicações que relatam as mais raras deformidades congênitas, uma menção deve ser feita da disostose cleido-craneana e coxa-vara congênita de Kanan, o trabalho de Wertheimer sobre a articulação e limitações do movimento da articulação do ombro e costelas cervicais de Araujo (ARAUJO, 1940; KANAN, 1939).

No que diz respeito às doenças metabólicas do osso deve-se destacar o trabalho de Ulhoa Cintra, que escreveu Doenças Ósseas Metabólicas, no qual uma nova realidade da doença - a variação da Síndrome de Fanconi, caracterizada pela falta de elemento glicosúrico - foi descrita, bem como seu tratamento adequado (CINTRA, 1949).

No campo das doenças ósseas, Hermto Junior: publicou A paratiroidectomia na moléstia de Engel-Recklinghausen; Os processos de reabsorção óssea. Significação e conseqüência cirúrgicas; forma mono-ostótica da moléstia de Engel-Recklinghausen; A freqüência do adenoma da paratireóide na moléstia de Engel Recklinghausen. No Rio de Janeiro, Magalhães Carvalho publicou uma monografia sobre o raquitismo (HERMETO JUNIOR, 1940,1942)

Na Faculdade de Medicina da Universidade da Bahia, região nordeste do Brasil, Benjamin Salles, em 1950, publicou vários trabalhos: Tratamento do pé varo equino congênito, uma monografia completa, incluindo as mais recentes contribuições para o assunto. Estudou detalhadamente a anatomia do Tallus congênito entre outros artigos: Considerações sobre a sindrome de Volkmann; Tratamento conservador da tuberculose osteoarticular na criança; Tratamento das fraturas do colo do fêmur pela osteosíntese com o parafuso de Godoy Moreira; Em torno das fraturas supracondilianas do úmero na criança (MOREIRA, 1940).

A incidência da tuberculose osteo-articular no Brasil é baixa, comparada com a incidência dos países europeus. Este fato deve-se, principalmente, à pasteurização do leite e ao fator de isolamento, porque no Brasil há sol quase o ano todo. Estatísticas mostram que a tuberculose é mais frequente nas cidades costeiras, como Recife, Rio de Janeiro e Santos.

A poliomielite, mais conhecida como paralisia infantil, demonstra na literatura o grande interesse do Brasil por esta doença. A poliomielite é endêmica em todos os estados da União e em muitos deles ela pode, ocasionalmente, ocorrer de várias formas epidêmicas. Pinheiro Campos, após estudo comparativo da doença entre os Estados Unidos e o Brasil, concluiu que ela é igualmente freqüente nos dois países.

Junto com os consideraveis desenvolvimentos técnicos em cada ramo da Medicina, o tratamento de fraturas tornou-se, hoje em dia, altamente especializado. Vários fatores podem mudar a prognose observando a fratura dada, no entanto, o único que se ressalta como a mais importante é o tipo de tratamento empregado. É justamente nesse aspecto que a habilidade do traumatologista faz a grande diferença. Familiar a todo tipo de fratura, assim como todos os métodos de tratamento, ele saberá qual o melhor método a ser aplicado em cada caso. Um outro ponto que apresenta uma influência definitiva sobre a conseqüência do tratamento é o instrumental cirúrgico adequado para o tratamento do trauma; o traumatologista deve, da mesma maneira, portanto, saber o que é mais eficiente em cada caso (GOMES, 2003)

Faz-se necessário explicar que o osso, uma vez que é resistente e rígido, representa o principal elemento de sustentação do corpo. $O$ tecido altamente mineralizado que o constitui - o tecido ósseo - exibe, além das suas propriedades mecânicas, uma alta capacidade de regeneração espontânea. Assim, fraturas ou defeitos ósseos são curados com a produção de um novo tecido ósseo com a mesma alta organização estrutural do tecido original. No entanto, esta capacidade regenerativa é limitada pelo tamanho da lesão; desse modo, defeitos ósseos extensos, provocados por 
traumas, infecções, neoplasias e anomalias de desenvolvimento não se regeneram espontaneamente, representando, pois, um problema atual da medicina e odontologia (LEIVAS, 2001). Na figura 19 os ossos humanos retirados de um doador, que são considerados ossos frescos.

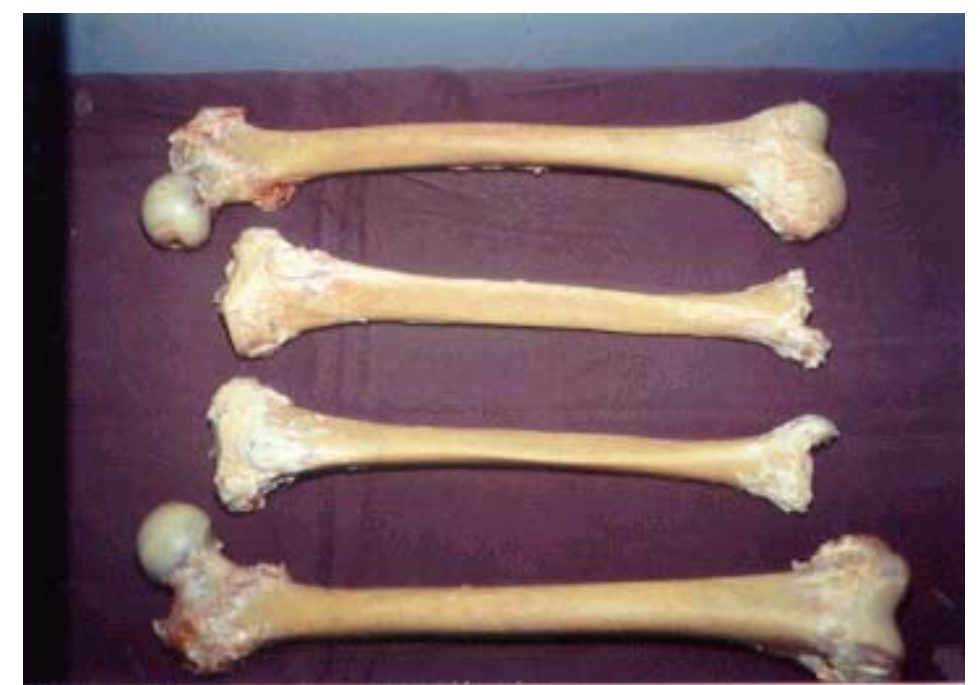

Figura 19 Ossos humanos, frescos, retirados de um doador

Fonte disponível em: $<$ http://www.unifesp.br/dorto-onco/banco Acesso em: 20 dez.2003

Um dos principais fatores que atua impedindo a regeneração é a rápida formação de tecido conjuntivo de origem óssea, que invade a área do defeito, dificultando ou impedindo parcial ou totalmente a neoformação óssea no local (FRAME, 1980; SCHIMTZ e HOLLINGER, 1986). Logo, vários procedimentos cirúrgicos têm sido desenvolvidos para o tratamento desse tipo de defeito. $\mathrm{O}$ mais comum é o enxerto ósseo autógeno, visto que apresenta características mais favoráveis à formação de novo tecido ósseo. (ASSEF e SCHRODER, 1998; ISAKSSON et al. 1992; SCHWARZ et al.,1991). Todavia, a estratégia do enxerto, embora se constitua como a melhor alternativa, pode apresentar vários inconvenientes, tais como: tamanho da área doadora limitada, risco de infecção na área doadora, intensa reabsorção, incorporação do material durante o processo de cicatrização e, principalmente no caso de crianças portadoras de grandes defeitos ósseos, a necessidade de uma segunda intervenção cirúrgica para obtenção do enxerto aumenta o tempo de cirurgia e o risco de mortalidade (COKLIN, 1971; YOUNGER e CHAPMAN, 1989).

$\mathrm{Na}$ ortopedia utilizam-se basicamente próteses que podem ser de dois tipos de grupos: convencionais e modulares. As convencionais são feitas em resina ou com componentes em plástico e madeira. São indicadas para todos os níveis de amputação com exceção da desarticulação de joelho. Trata-se de um sistema robusto, utilizado principalmente quando situações adversas como determinadas atividades ou hábitos da paciente, condições geográficas, não permitem o uso de próteses mais sofisticadas. As próteses modular também chamada de prótese endoesquelética com revestimento cosmético em espuma, este sistema foi lançado em 1969, pela Otto Bock, sendo então constantemente aperfeiçoado, podem ser utilizadas em todos os níveis de amputação de membro inferior, são constituídas por vários módulos ajustáveis e intercambiáveis entre 
si, mais leves e estétivas por serem revestidas de espuma cosmética, seus componentes podem ser em aço titânio (um metal extremamente leve e resistente, muito mais resistente a oxidação que o aço chamado (indevidamente) de inoxidável), aluminio e fibra de carbono, essas próteses oferecem ampla linha de opções para uma protetização eficaz (LEIVAS, 2001)

Os encaixes das próteses evoluiram muito nos últimos anos. As resinas substituíram os encaixes de madeira e, mais recentemente, os materiais plásticos termoplásticos estão substituíndo as resinas.

No campo da ortopedia alguns problemas graves relacionados com os implantes metálicos referentes aos materiais de osteossíntese, ou seja, aqueles usados para consolidar fraturas ósseas, têm, geralmente, uma vida útil bem definida. Quase sempre são retirados assim que osso restabelece, antes que a corrosão o danifique (MARCZYK, 2003).

Cabe aqui mencionar que o parafuso que Orlando Pinto de Souza, médico ortopedista, desenvolveu, nos anos setenta era confeccionado em uma ofícina particular na cidade de São Paulo por Orlando de Carvalho e seu pai Ivo de Carvalho, proprietários. Ivo de Carvalho o qual foi fundador e diretor da empresa Carci Indústria e Comércio de aparelhos cirúrgicos e ortopédicos Ltda, e que na época não patentearam este produto como sendo um parafuso desenvolvido no Brasil.

As próteses ortopédicas têm uso por tempo prolongado e sofrem com o meio altamente agressivo que constitui o organismo humano, cujos fluídos, ricos em cloreto de sódio, estimulam a corrrosão. Leivas, chefe do Laboratório Investigação |Médica LIM, Instituto de Ortopedia e Traumatologia - IOT, Hospital Clínicas São Paulo HCSP, afirma "elas deveriam acompanhar o paciente pela vida inteira, mas duram no máximo uns quinze anos". Para evitar esses problemas, surgem materiais cada vez mais resistentes. Atualmente o melhor deles é o titânio, também é utilizado, sobretudo nos Estados Unidos, o Vitallium, uma liga de cromo, cobalto e molibdênio. No Brasil o material mais empregado é o aço inoxidável. Questão de custo (LEIVAS, 2001). Observe na figura 20 uma prótese fabricada em titânio, para membro inferior. Note também na figura 21 uma ortese infantil, da cor da moda, que pode ser colocada e retirada pelo próprio paciente.

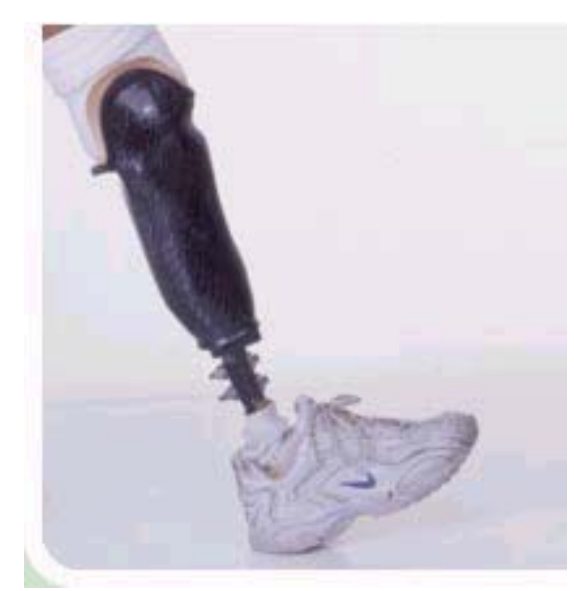

Figura 19. Prótese

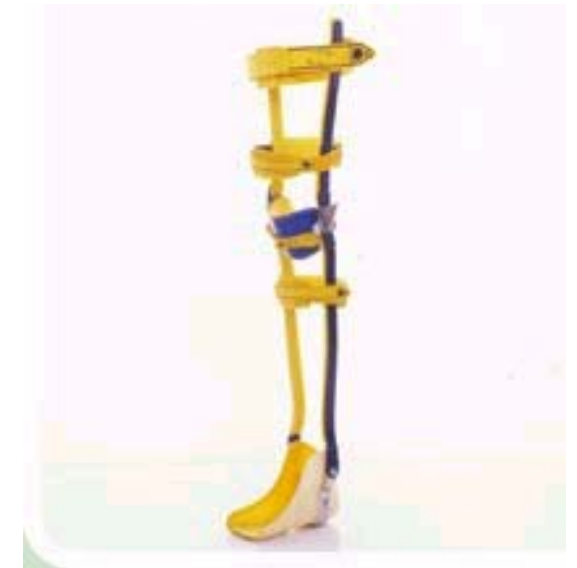

Figura 20. Ortese

Fonte disponível em: $<$ http://www.aacd.org.br/ortopedia Acesso em: 20 dez. 2003 
O Aço comum é formado por ferro e carbono, sendo facilmente oxidado, o aço inoxidável empregado em implantes ortopédicos - um tipo especial de aço não magnético chamado de "austenítico" tem ainda níquel e cromo em sua composição química. O níquel e o cromo aumentam sua resistência à corrosão por meio de uma reação do cromo com o oxigênio. Forma-se uma pelicula de óxido de cromo na superfície do aço, que atuará como um protetor impermeabilizante. Contudo, se durante uma cirurgia houver qualquer arranhão na prótese a ser implantada, está aberto o caminho para a corrosão (LEIVAS, 2001)

As possibilidades de criar recursos que ajudassem o homem a ter de volta movimentos e sentidos perdidos tornaram-se mais reais. Assim, as pesquisas em próteses eletrônicas começaram a ganhar impulso e impulsionar outras tantas áreas, como a da nanotecnologia e de chips especiais.

Tudo começou, porém, quando nos anos noventa diversos laboratórios ao redor do mundo resolveram empenhar-se na criação de redes neurais artificiais. Com isso, os pesquisadores pretendiam imitar o funcionamento do cérebro humano através de chips com arquitetura especial. Assim eles puderam desenvolver algumas aplicações para o ser humano.

Os pesquisadores lembram, porém, que essas tecnologias e novas possibilidades de corrigir problemas físicos do ser humano não devem ser interpretadas como algo milagroso e ainda está caminhando para uma popularização e resultados mais perto dos esperados.

Aumentou muito o índice de pessoas portadoras de materiais implantáveis, seje na ortopedia, cardiologia, odontologia, isso comprova que os materiais que foram utilizados no ínicio da bioengenharia, que era feita sem levar este nome, fez com que os pesquisadores melhorassem a qualidade destas próteses, e prolongando a vida dos seres humanos.

\subsection{APLICAÇAO DA BIOENGENHARIA NA ODONTOLOGIA}

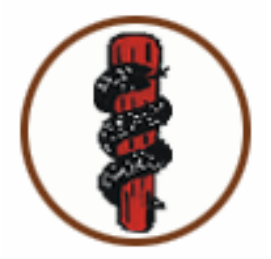

A odontologia é um lento e contínuo suceder-se de fatos, de realizações, influenciados sempre pelos acontecimentos anteriores, permitindo-lhe tornar-se uma ciência de idéias e fatos.

A história da odontologia revelou, através dos tempos, ser ela uma ciência experimental, no sentido filosófico. O mesmo se deu com os acontecimentos, com as coisas e pessoas. Como resultado, decorreram leis que possibilitaram o desenvolvimento de pensamento odontológico.

A necessidade de tratamento de uma enfermidade dentária surgiu em tempos remotos. As primeiras civilizações humanas, no início, desenvolveram tentativas no sentido de recolocar os próprios dentes avulsos, quando ocorriam acidentes ou traumas. 
Mas, logo em seguida, passou-se para a substituição do dente perdido por elemento similar. Em 1500, reaparece o interesse pelo ensino clássico e o pensamento científico estava presente; em 1530, Blun publica o primeiro livro odontológico (CAMPOS, 1944).

É fato conhecido que no Brasil, até fins do século XIX, não eram realizados procedimentos cirúrgico a não ser aqueles mais simples, os quais ficava a cargo do "barbeiro", "barbeiro sangrador" "ou "cirurgião-barbeiro", que praticava sangria e escarificações, aplicava ventosas, sanguessugas e clisters, lancetava abscessos, fazia curativos, excisava prepucios, tratava as mordeduras de cobras, arrancava dentes, etc. A grande maioria era constituída de leigos, incultos e de humilde classe social.

No Brasil, esta área médica, após a descoberta, em 1500, restringia-se quase que só às extrações dentárias. As técnicas eram rudimentares, o instrumental inadequado e não havia nenhuma forma de higiene.

O barbeiro ou sangrador, como era conhecido o profissional da área nesse período, deveria, pois, ser forte, impiedoso, impassível e rápido. Os médicos (físicos) e cirurgiões, diante de tanta crueldade, evitavam essa tarefa, enfatizando os riscos para o paciente de hemorragias e inevitáveis infecções (com possibilidade de morte). Argumentavam que as mãos do profissional poderiam ficar pesadas e sem condições para intervenções delicadas. Os barbeiros e sangradores eram geralmente ignorantes e tinham um baixo conceito, aprendendo esta atividade com alguém mais experiente (CUNHA, 1968). Observe na figura 22, podendo ser observado que a extração dentária com método rudimentar, sendo praticada em praça pública.

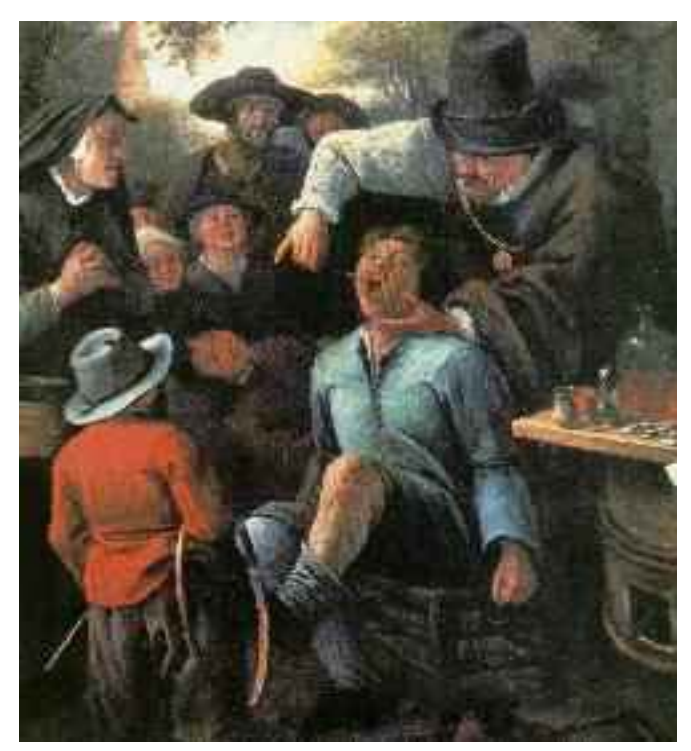

Figura 22 Extração dentária com método rudimentar

Fonte disponível em: $<$ http://www.mundobucal.com.br Acesso em 20 dezembro 2003

Para exercer esta atividade, os profissionais dependiam de uma licença especial dada pelo "cirurgião-mor mestre Gil", sendo os infratores autuados, presos e multados em três marcos de ouro (segundo a norma da Carta Régia de 25 de outubro de 1448, de 
El Rei D. Afonso, de Portugal, dando "carta de ofício de cirurgião-mor destes reinos"). A carta de oficio não se referia aos barbeiros e sangradores, havendo a possibilidade destes profissionais terem obtido licença do cirurgião-mor de Portugal.

$\mathrm{Na}$ odontologia, Bartholomaeus Eustachius, romano (1520-1590) reportou-se aos ligamentos periodontais pela primeira vez e, Ambroise Paré, francês, (1517-1590), sugeriu técnicas mais esmeradas de raspagem e de gengivectomia. Sendo que o primeiro livro odontológico foi publicado em 1530, em alemão, por Blum.

Em 09 de novembro de 1629 houve, através da Carta Régia, os exames aos cirurgiões e barbeiros. A reforma do regimento em 12 de outubro de 1631 determinava a multa de dois mil réis às pessoas que "tirassem dentes" sem licença. Parece que sangrador e tiradentes, oficios acumulados pelos barbeiros, eram coisas que se confundiam, podendo o sangrador também tirar dentes, pois nos exames de habilitação tinham de provar que durante dois anos "sangravam" e fizeram as demais atividades de barbeiro (CUNHA, 1931).

Pierre Fauchard, francês, tornou-se o pai da Odontologia, alterando toda a concepção de instrumentos e técnicas da época e transformando, assim, a prática odontológica. Seu livro O Cirurgião-Dentista, publicado em 1728, deu notoriedade e respeito à categoria, influenciando a odontologia norte-americana. $\mathrm{O}$ livro versava sobre Dentistica, Prótese, Cirurgia, Periodontia, Ortodontia e Prevenção. Os escritos de Fauchard atravessaram continentes (SAMICO, 1992).

Pela lei de 17 de junho de 1782, nas colônias portuguesas, incluindo o Brasil foi criada a Real junta de Proto-Medicato que era constituída de sete deputados, médicos ou cirurgiões, para um período de tres anos, e caberia a estes o exame e a expedição de cartas e licenciamento das pessoas que tirassem dentes (BRITTO, 1940).

No período de 1790, os dentes eram extraídos com as chaves de Garangeot, alavancas rudimentares, e o pelicano. Não se fazia tratamento de canais e as obturações eram de chumbo, sobre tecido cariado e polpas afetadas, com consequências desastrosas.

Os barbeiros e sangradores aprendiam o oficio com um mais experiente e tinham que provar uma prática de dois anos sob a vista do mais experiente. Após pagar uma taxa de oito oitavos de ouro, submeter-se-ia a exame perante o cirurgião substituto de Minas Gerais e dois profissionais escolhidos por eles. Aprovados, teriam suas cartas expedidas e licenças concedidas (BRASIL,1985).

Em 23 de maio de 1800, cria-se o "plano de exames", um aperfeiçoamento das formalidades e dos exames. É encontrado pela primeira vez em documentos do Reino, o vocábulo "dentista". Convém lembrar que foi criado pelo cirurgião francês Guy Chauliac, a palavra "dentista" aparecendo pela primeira vez em seu livro "Chirurgia Magna” publicado em 1363 (BRASIL,1891).

No Hospital de São José, na Bahia, criava-se a Escola de Cirurgia, graças à interferência do Dr. José Correa Picanço, físico e cirurgião-mor; em nome da Real Junta do Proto-Medicato. Isto nada beneficiou os dentistas na ocasião. Picanço a seguir não só licenciou os profissionais da corte, como sete negros, de baixa classe social, alguns até escravos de poderosos senhores (SAMICO,1953).

Havia nesta época dois ditados populares "ou casa, ou dente" ou "ou dente, ou queixo, ou língua, ou beiço". Isto indica que o pouco conhecimento e a inabilidade dos "tira-dentes" provocava freqüentemente traumatismos nestas regiões.

Eram realizadas inúmeras queixas contra os profissionais e para moralizar esta atividade, o cirurgião-mor determinava em suas cartas, que o barbeiro poderia exercer a sua arte com restrições "não sangrando sem ordem de médico ou cirurgião aprovados, não tirando dentes sem ser examinado" (SAMICO, 1953). 
Antes do final de 1808, D.João transfere-se de Salvador, capital da Bahia, para a cidade do Rio de Janeiro. Em 07 de outubro de 1809, é abolida a Real Junta do ProtoMedicato, ficando todas as responsabilidades ao encargo do físico-mor e do cirurgiãomor, com a colaboração de seus delegados e subdelegados (LEITE, 1962).

O fisico-mor do Reino era Manoel Vieira da Silva, encarregado do controle do exercício de Medicina e Farmácia e o cirurgião-mór dos exércitos, José Correa Picanço tinha poderes análogos em relação à cirurgia, controlando o exercício das funções realizadas pelos sangradores, dentistas, parteiras e algebristas.

Alguns cirurgiões também tiravam "carta de sangria" e indiscutivelmente o povo era beneficiado. Nesta época, o mestre Domingos "barbeiro" popular no bairro da Saúde, no Rio de Janeiro, se tornou famoso. O negro mestiço exercia suas atividades também na casa dos clientes. Sob os braços levava uma esteira de taboa, que servia de cadeira e uma enferrujada chave de Garangeot (FARIAS SOBRINHO, 1973).

Dado às manobras da extração dentária, algumas vezes se arrancava o dente vizinho, mas cobrava-se apenas um. Havia dentaduras esculpidas em osso, por um crioulo, que as vendia de acordo com a beleza e a que melhor se adaptasse a boca do cliente.

Diplomado pela Faculdade de Odontologia de Paris, o francês, Dr.Eugênio Frederico Guertin, em 1820, recebe a carta para exercer a profissão no Rio de Janeiro, atendendo grande parte da nobreza, publicou "Avisos Tendentes à Conservação dos Dentes e sua Substituição" considerada a primeira obra de odontologia publicada no Brasil (COSTA, 1928).

Outros dentistas franceses vieram a seguir, trazendo o que havia de melhor na Odontologia mundial. Foi criado até uma tabela de honorários, dentes artificiais de cavalo marinho ou marfim 4.000 réis, natural 12.000 réis, incorruptível (porcelana) 24.000 réis. As dentaduras eram constituídas de duas fileiras de dentes, esculpidas em marfim ou adaptadas em base metálica, sendo as arcadas ligadas por molas elásticas. $\mathrm{Na}$ cidade do Rio de Janeiro, logo após a Independência do Brasil em 01 de junho de 1824, Gregório Raphael Silva recebeu a primeira "carta de dentista" (COSTA, 1928).

D.Pedro I suprime o cargo de cirurgião-mor, cuja função passou a ser exercida pelas Câmaras Municipais e Justiças Ordinárias, em 30 de agosto de 1828. Há uma única obra iconográfica relacionada à atividade de profissionais que exerciam a Odontologia. Denomina-se "Boutiques de Barbieri" e retrata dizeres "barbeiro, cabeleireiro, sangrador, dentista e deitão bichas".

No Brasil, chega ao Rio de Janeiro o dentista portugues Luiz Antunes de Carvalho, que obteve notoriedade e riqueza, sendo um dos pioneiros na cirurgia bucomaxilar no ano de 1832, publicou no Almanak Administrativo Mercantil e Comercial "enxerta outros dentes nas raízes podres, firma dentes e dentaduras inteiras, firma queixo, céu da boca, narizes artificiais e cura moléstias da boca", rua Larga de São Joaquim, 125 (CUNHA, 1968).

Chaplin A. Harris, em Baltimore, Estados Unidos, em 1839 cria a primeira escola do mundo a ensinar Odontologia. É o inicio da era do desenvolvimento odontológico baseado no conhecimento científico e tecnológico

A partir de 1840, começou chegar ao Brasil dentistas dos Estados Unidos e pouco a pouco suplantaram os dentistas franceses, Clintin Van Tuy, o primeiro a utilizar o clorofórmio (só em casos excepcionais) para anestesia, conforme publicação de seu livro “Guia dos Dentes Sãos” publicado em 1849 (FÁVERO,1975).

John Riggs, norte americano (1811-1885), introduziu o conceito de "Piorréia Alveolar", necrose óssea associada à doença periodontal. Uniu-se a Horace Wells, que extraira o primeiro elemento dentário sob anestesia, a base de óxido nitroso, em 1844. 
No Brasil, a primeira anestesia geral pelo éter foi praticada no Hospital Militar do Rio de Janeiro, pelo médico Roberto Jorge Haddock Lobo, em 25 de maio de 1847 (SANTOS FILHO, 1980).

Uma semana após, foi utilizada por Domingos Marinho de Azevedo Americano em dois soldados tendo sido anestesista o médico Dr.Leslie Castro, recém chegado da Europa e trazia consigo o anestésico e o aparelho de "eterização". Um dos soldados foi operado com sucesso, sem dor, de osteomielite fistulizada da mastóide; o outro era alcoólatra e a anestesia não produziu insensibilidade (SANTOS FILHO, 1980).

O éter foi logo substituído pelo clorofórmio, que havia sido introduzido como anestésico na Inglaterra por James Simpson, em 1847. A primeira anestesia geral com o clorofórmio foi empregada pelo Prof. Manuel Feliciano Pereira de Carvalho, na Santa Casa de Misericórdia do Rio de Janeiro, em 18 de fevereiro de 1848.

Mentes mais lúcidas procuravam a melhoria do ensino e normas um pouco mais criteriosas e normalizadoras àqueles que desejassem praticar a Medicina e Odontologia.

Novos estatutos da Faculdade de Medicina do Rio de Janeiro foram aprovados em 28 de abril de 1854, por proposta de seu diretor José Martins de Cruz Jobim. A nomeação contribuiu para o desenvolvimento da profissão, principalmente nas cidades do Rio de Janeiro e São Paulo (ALMEIDA, 1934).

No ano de 1863, vinte dentistas formados em medicina; surge a legislação profissional. Primeiros cursos com duração de dois anos (teóricos); separação ou dicotomia entre a prática e o saber, posteriormente a profissão veio a se firmar como nível superior. Jõao Borges Diniz, em setembro de 1869, cria a primeira Revista Odontológica no Brasil, entitulada "Arte Dentária" (AZEVEDO, 1963).

Os Estados Unidos lideram a evolução técnica e científica mundial, e muitos brasileiros para lá se dirigiam a fim de se aperfeiçoar. O primeiro do Estado do Rio Grande do Sul, Carlos Alonso Hastings, estudou no Philadélfia Dental College, radicouse no Rio de Janeiro e modificou o motor Weber-Ferry, que ficou conhecido como motor de Hastings.

A partir das modificações do ensino médico estabelecido pela Reforma Leôncio de Carvalho (decreto n.7.247 de 19 de abril de 1879), foi prevista a criação do curso de odontologia com anexo à Faculdade de Medicina do Rio de Janeior e à faculdade de Medicina da Bahia, as únicas existentes no Império. No entanto, essa criação só foi efetivada com a Reforma Sabóia, em 1884 (ALMEIDA, 1934).

Faltava apenas um líder e visionário para instituir o ensino Odontológico no Brasil. Vem na pessoa de Vicente Cândido Sabóia, mais tarde Visconde de Sabóia, que assumindo a direção da Faculdade de Medicina em 23 de fevereiro de 1880, resolveu inicialmente atualizar o ensino, tanto material como cientificamente (SAMICO, 1953).

O decreto 8024 de 12 de março de 1881, artigo 94 do Regulamento para os exames das faculdades de Medicina diz: "Os cirurgiões-dentistas que quisessem se habilitar para o exercício de sua profissão passarão por duas séries de exames: - $\mathrm{O}$ primeiro de anatomia, histologia e higiêne, em suas aplicações à arte dentária. $\mathrm{O}$ outro de operações e próteses dentárias" (FẢVERO, 1975).

A seguir, cria o laboratório de cirurgia dentária, encomendando aparelhos e instrumentos dos Estados Unidos. Com crédito especial obtido na lei 3141, de 30 de outubro de 1882, monta também o laboratório de prótese dentária.

Pelos decretos 8850 e 8851 , de 13 de janeiro de 1883, o cirurgião-dentista Thomas Gomes dos Santos Filho é aprovado em primeiro lugar no concurso, como 
preparador. Descobriu a fórmula de vulcanite e em seguida a produzi. Conseguindo suprir a falta de material e combater os preços abusivos (GALVÃO NETO, 1990).

Um novo texto nos Estatutos das Faculdades de Medicina do Império, denominada Reforma Sabóias, apresentada em 25 de outubro de 1884, através do Decreto 9311 com seguinte enunciado; "Dá novos Estatutos às Faculdades de Medicina do Rio de Janeiro".

Usando da autorização concedida pelo artigo 2, Parágrafo 7, da lei 3141 de 30 de outubro de 1882 - Hei por bem que nas Faculdades de Medicina do Império se observem os novos estatutos que com este baixam, assinados por Filippe Franco de Sá; do Meu Conselho, Senador do Império que assim o tenha entendido e faça executar. Palácio do Rio de Janeiro, em 25 de outubro de 1884, da Independência do Império (BRASIL, 1985).

Assim:

Artigo 1 - Cada uma das Faculdades de Medicina do Império se designará pelo nome da cidade em que tiver assento; seja regida por um diretor e pela Congregação das Lentes, e as comporá de um curso de ciências médicas e cirurgicas e de tres cursos anexos: o de Farmácia, o de Obstetricia e Ginacologia e o de Odontologia.

- (a) Havia apenas as Faculdades de Medicina do Rio de Janeiro e de Salvador. b)Compreende-se porque a primeira Escola de Odontologia de São Paulo, criada em 07 de dezembro de 1900, denominou-se nos primeiros anos, Escola de Farmácia, Odontologia e Obstetricia de São Paulo.

No capítulo II, a Sessão IV tem o título: "Do curso de Odontologia" Artigo 9

Das matérias neste curso haverá tres séries.

$l^{\text {a }}$ série: Física, quimica mineral, anatomia descritiva e topografia da cabeça.

$2^{a}$ série: Histologia dentária, fisiologia dentária, patologia dentária, higiene da

boca.

$3^{a}$ série: Terapêutica dentária, cirurgia e prótese dentária.

Em 1911, criou-se no Brasil a APCD - Associação Paulista dos Cirurugiões Dentistas.

No Brasil, em 1926, o Relatório de Gies: propunha de uma reorganização do ensino e da prática odontológica em um modelo biologicista e curativista com enfoque na cura e reabilitação da doença, que continuava monopólio e mecanicista.

No Brasil, criou-se em 1931, o primeiro sindicato da classe. E em 1934 a extinção da atividade de Prático (atividade se torna ilegal) Em 1935, Kronfeld superou o conceito de "necrose ósssea", no qual a "Piorréia Alveolar" baseava-se até então.

Há um grande interesse em práticas preventivas coletivas, e avanços importantes a partir das experiências de Knutson-1943, com a aplicação tópica de fluor em programas escolares.

No estado de Espírito Santo, na cidade de Baixo Guandu, implantou-se o primeiro sistema de fluoretação de águas de abastecimento público no Brasil. Método utilizado para que a população obtenha uma melhor qualidade de vida, e preserve mais os dentes. No Brasil em 1956, Rugerpe Pedreira trouxe e traduziu o livro de Periodontia, de Merrit. Os CROs - Conselho Regional de Odontologia foram criados no Brasil em 1964 (BRITTO, 1940).

$\mathrm{Na}$ atualidade, o processo saúde-doença, em Periodontia, é dinâmico e sujeito às interferências de ordem local e geral. Compreende-se, que uma série de dificuldades podem estar relacionadas à obtenção deste equilibrio.

Os fatores determinantes para o estabelecimento das periodontopatias são algumas bactérias de microbiótica bucal. Entretanto, fatores predisponentes, assim como modificantes, podem interferir neste processo, a considerar: idade, sexo e classe 
econômica; nível educacional; necessidade social e profissional, estresse, medo e ansiedade. Tabagismo e higiene bucal, saliva, fluido gengival e dieta, hereditariedade e imunocompetência (AZEVEDO, 1963).

Hoje, a odontologia, de uma prática eminentemente empírica e artesanal no passado, exige intervenções científicas, epistemológicas e multidisciplinares.

O dentista é o profissional que cuida e faz a prevenção da saúde bucal. Ele diagnostica e trata cáries, canais, doenças gengivais, além de extrair, reimplantar, corrigir a estética e a posição de (aparelhos ortodônticos) dos dentes. É também o dentista quem identifica cadáveres através da arcada dentária. Em algumas situações trabalha associado aos otorrinolaringologistas, psicólogos e fonoaudiólogos. São características imprescindíveis ao Dentista: a paciência, a concentração, a flexibilidade, a criatividade e as habilidades manuais (GALVÃO NETO, 1990).

\subsubsection{HISTORIA DA PRÓTESE DENTÁRIA}

A história das infecções dentária remonta bem antes do aparecimento da espécie "Homo" no planeta terra. Alguns cientistas relatam que foi um dos motivos que apressou a extinção dos animais pré-históricos. Segundo estudos realizados em ossadas encontradas em várias partes do planeta, mais diretamente, nos dentes fossilizados de alguns animais, havia indícios de lesões de cáries e também sinais de outras infecções orais, que também acompanham a humanidade desde a sua origem.

Estudiosos que encontraram, por meio de escavações, o homem de neandertal observaram a falta de dois molares, cuja perda pode ser relacionada à periodontite avançada, conhecida popularmente como piorréia alveolar. Outra característica observada foi a de que entre as arcadas dos homens da pré-história, havia um acentuado grau de atrição dentária, que em alguns casos levou ao completo desaparecimento de cuspides e fissuras, podendo constituir a mais freqüente causa das inflamações periapiciais, em virtude de exposição e necrose pulpar (ENSELME, 1973).

Observe na figura 23 crânio homem de neandertal, com boa visão da arcada dentária.

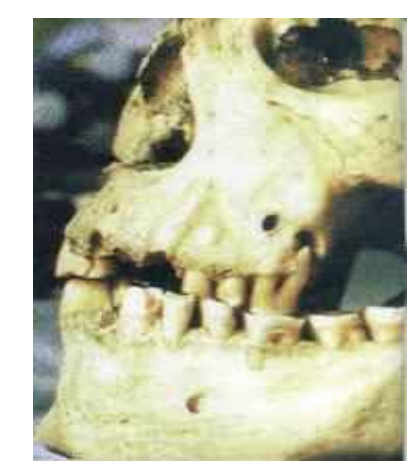

Figura 23 Crânio homem de neandertal

Fonte disponível em: $<$ http://www.mundobucal.com.br Acesso em: 20 de dez.2003 
A alimentação naquele período, nas regiões onde posteriormente habitavam os povos do Egito e da China, era ingerida crua, sem preparação. A dieta era feita à base de trigo, cevada, arroz e tubérculos, que deram lugar ao consumo de pescados e à vida próxima ao curso dos rios, após a descoberta do fogo. Em razão dessa mudança no hábito alimentar, a boca sofreu várias transformações: os molares, que antes acompanhavam o indivíduo a vida toda, começaram a cair, as gengivas se inflamaram e perderam tecido e o rosto passou a apresentar inchaço, características que outras tribos que viviam no interior não tiveram.

Para muitos historiadores da odontologia, os Fenícios foram os verdadeiros precursores da prótese dentária e os seus conhecimentos foram transmitidos aos outros povos mediterrâneo. Esses conhecimentos constavam de dados terapêuticos sobre a odontologia, principalmente referentes à habilidade da prótese. Essa habilidade se caracteriza de duas maneiras: Figuras 24 e 25 . Na figura 24 prótese mandibular fixa quatro incisivos humanos naturais e dois dentes talhados em marfim

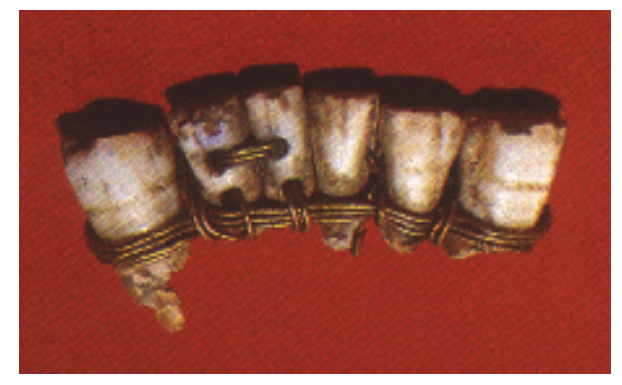

Figura 24 Prótese mandibular fixa quatro incisivos humanos naturais edois dentes talhados em marfim. Fonte disponível em:<http://www.mundobucal.com.br Acesso em 20 de dez. 2003

Em um dos casos, utilizava-se de seis dentes, dois caninos e quatro incisivos, ligados com grande habilidade por um fio de ouro puro do comprimento aproximado de trinta centimetros de diâmetro extremamente fino. $O$ central e o lateral direito pertencem a outra pessoa e substituem os ausentes. No conjunto, este sistema protético desempenha funções de substituir os dentes ausentes e de fixar os outros dentes a tipo férula. Sendo uma prótese parcial fixa no maxilar superior feminino.

A outra maneira constituía-se de uma mandíbula com prótese em ouro, construída por um fio de ouro que encerrava seis dentes anteriores com finalidade fixativa, devido às rugosidades marcadas das inserções musculares devia pertencer a um homem muito forte.

Os Etruscos eram ourives e nesta arte desenvolveram técnicas de valor. Eles usaram aros soldados para solidarizar grupos de dentes, criando assim, um esteio para os dentes postiços. A liga empregada era de ouro quase puro, fundido em lâminas espessas e resistentes. A solda era de tão boa qualidade que não se alterou em contato com a terra durante tanto tempo. Note na figura 25 dente artificial ou pôntico, ele substituía o incisivo superior central direito e provavelmente tratava-se de um dente de boi preso por rebite à lamina de ouro. 


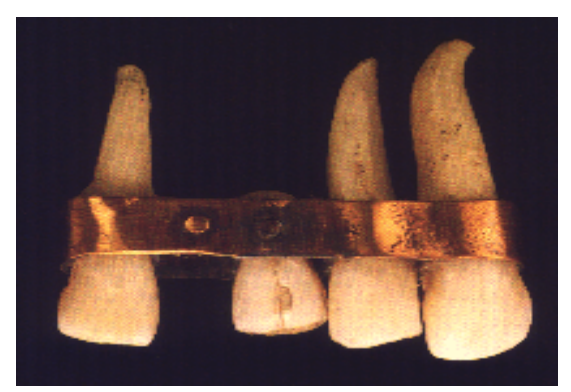

Figura 25 Dente artificial ou pôntico, deste fragmento de dentadura fixa etruca se perdeu, ele substituia o incisivo superior central direito, e provavelmente tratava-se de um dente de boi preso por rebite à lamina de ouro.

Fonte disponível em:<http://www.mundobucal.com.br Acesso em 20 dez. 2003

Os dentes de substituição eram perfurados e depois fixados por meio de uma barra horizontal em toda a espessura. Certamente devido ao caráter sagrado do corpo humano, não podiam usar a não ser dentes da própria pessoa. No entanto, como morriam mais animais do que homens, eles passaram a recorrer aos dentes dos animais, os quais eram reduzidos e adaptados, para fazer as suas próteses parciais fixas, ou então removíveis.

Os Egípcios também realizavam próteses e estas são consideradas as raízes da tecnologia odontológica. As próteses procuravam substituir o membro que falhava e também procuravam fixá-lo. Este antigo dispositivo protético consiste de dois dentes conectados com fio de ouro; são o primeiro e o segundo molar ligado ao terceiro molar, o dispositivo é mais provavelmente de uma férula para dois dentes adjacentes, para proporcionar retenção para um molar anterior, enfraquecido pela reabsorção radicular, no terceiro molar.Note na figura 26 dente canino duplamente preso com fio de ouro e dois incisivos direitos unidos entre si com fio de ouro enfiado através do incisivo central e atado ao incisivo lateral com uma volta.

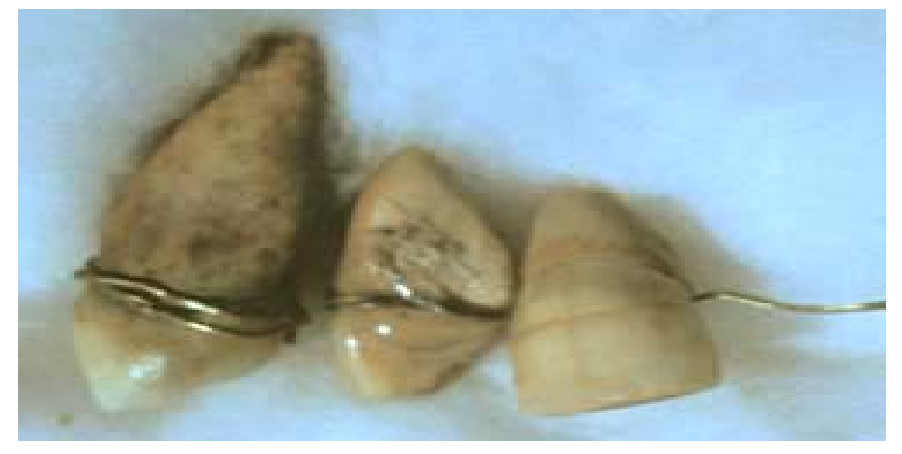

Figura 26 Dente canino duplamente preso com fio de ouro e dois incisivos direitos unidos entre si com fio de ouro enfiado através do incisivo central e atado ao incisivo lateral com uma volta. Uma ponte fixa que pertence ao Reino Antigo. 
Os Romanos tinham uma lei que permitia o enterramento do ouro, só se fosse nos dentes. Na literatura médica romana, não há referência às próteses porque elas eram executadas por técnicos, servindo apenas para efeitos estéticos. Acredita-se que as próteses eram executadas pelos ourives, mas seus trabalhos não foram descritos nos tratados médicos por razões sociais.

Os Romanos usavam próteses removíveis, mas havia também a prótese parcial. Nessa ocasião, apareceu o marfim como material novo, sendo utilizado para fins protéticos. A técnica dos romanos permaneceu inalterada até a Renascença. Foi nesse período que se produziram os primeiros dentrifícios e instrumentos mais delicados.

Os Maias não praticavam odontologia reparadora ou restauradora para manutenção ou melhora da saúde bucal. Seus trabalhos habilidosos com os dentes tinham finalidade apenas como rituais religiosos. Eles sabiam incrustar com habilidade lindas pedras em cavidades cuidadosamente preparadas nos incisivos superiores e inferiores, em alguns casos, nos primeiros molares. As cavidades eram criadas em dentes vivos.

Observe na figura 27 dentes de um crânio da comunidade Maia, do século IX DC traz várias incrustações de jade e turquesa.

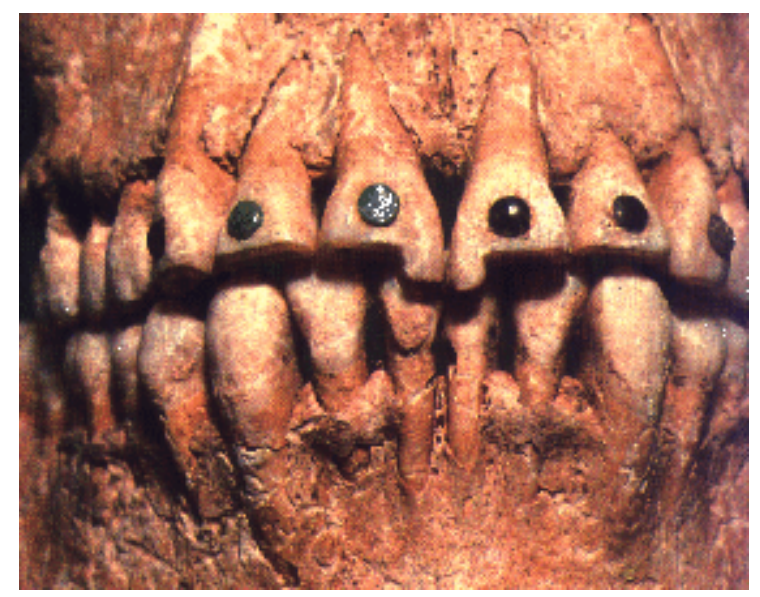

Figura 27 Dentes de um crânio da comunidade Maia,do século IX D.C. traz várias incrustrações de jade e turquesa. Museu Nacional de Antropologia.

Fonte disponível em:<http://www.dentes.org/prosthodontics.htm Acesso em: 20 dez. 2003

Faziam girar, com as mãos ou com uma furadeira de arco de corda, um tubo duro e redondo, parecido com um canudo de refresco. As pedras incrustadas se ajustavam de forma tão exata à cavidade, que muitas delas permaneceram no lugar durante mil anos. Como forma de aumentar a conservação das duas peças unidas, o espaço entre a pedra e as paredes da cavidade eram vedadas por meio de cimentos.

Os Maias praticaram a implantação de materiais aloplásticos (não orgânicos) em pessoas vivas (BOBBIO, 1970). Contrariamente à opinião inicial, segundo a qual estes fragmentos teriam sido inseridos depois da morte, as provas radiológicas efetuadas (Bobbio) em 1970 comprovaram a formação de osso compacto em torno de dois implantes, osso radiograficamente similar ao que envolveria implante de lâmina atual. Em consequência, estes são os dois implantes endosteais (dentro do osso) aloplásticos (não orgânicos) mais antigos já descobertos. 
Os Japoneses dominavam a arte de talha em madeira, sendo possível, portanto, que as primeiras próteses de madeira tenham sido confeccionadas nesta época. Os Japoneses construíam próteses completas, superiores e inferiores, sustentadas simplesmente pela aderência e pressão atmosférica. $\mathrm{O}$ fato de estas dentaduras terem sido confeccionadas de madeira é muito interessante. Foram encontradas mais de 120 dentaduras completas de madeira, que datam de princípios do século XVI, até meados do século XIX.

Eram talhados de um único bloco de madeira, normalmente de árvore de aroma doce como bluxo, a cerejeira, ou o damasqueiro. Como se pode observar na figura 28 como uma dentadura completa confeccionada para um samurai, que foi descoberta em Tóquio, no ano de 1927.

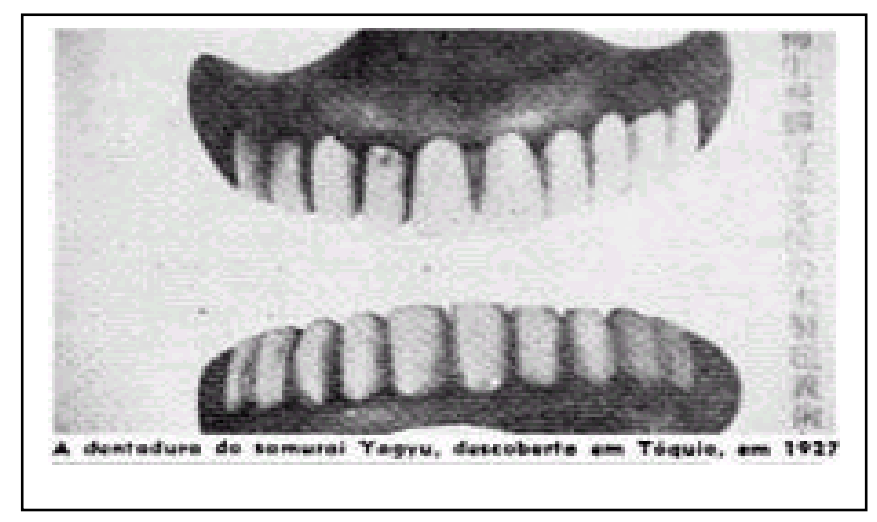

Figura 28 Dentadura completa confeccionada em madeira

Fonte disponível em: $<$ http://www.protesetotal.odo.br Acesso em 20 de dez. 2003

Era confeccionado um molde do maxilar desdentado com cera de abelha e, com base neste molde, talhava-se um modelo, geralmente de madeira. Em seguida, talhava-se a dentadura, seguindo aproximadamente este modelo. Depois, o céu da boca do paciente era pintado com um pigmento vermelho, ou com tinta nanquim, e com base na impressão dos pontos salientes, a dentadura ia sendo trabalhada, ajustando-a à parte interior da boca. Este procedimento não difere muito do método ocidental, em época mais recente, de modelar e ajustar na boca dentaduras com base de marfim (COSTA, 1928). Note na figura 29 um molde confeccionado em madeira. 


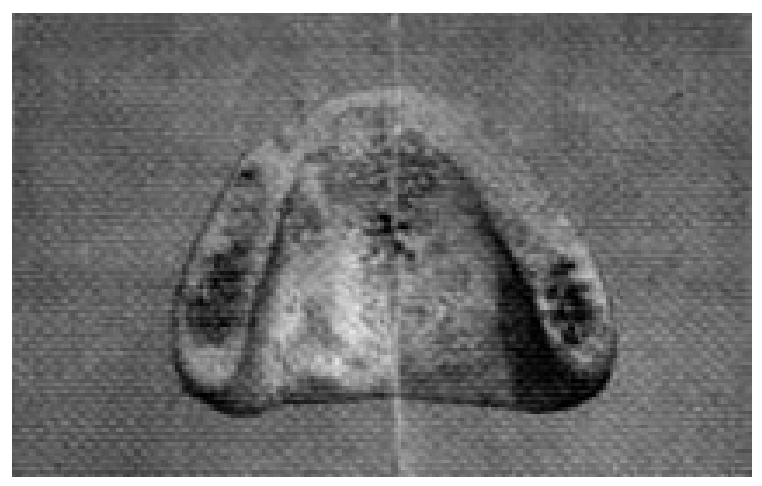

Figura 29 Molde confeccionado em madeira

Fonte disponível em: $<$ http://www.protesetotal.odo.br Acesso em: 20 dez. 2003

Os dentes artificiais eram confeccionados com lascas de mármore ou osso de animais talhados sob medida, e algumas vezes também eram utilizados dentes humanos naturais. Em lugar das molas posteriores, pregavam na base de madeira cravos de cobre e ferro, visando aumentar a eficácia da mastigação.

Se o cliente assim o exigisse, os dentes e suas bordas eram pintados de negro, para indicar a condição matrimonial da mulher que iria utilizar a dentadura; finalmente, a prótese era interiramente recoberta por laca (verniz da China, preto ou vernelho), para torná-la resistente à ação da saliva (COSTA, 1928).

A prótese dentária superior japonesa mais antiga que se conhece pertenceu a uma sacerdotisa budista, Nakaoka Tei, conhecida familiarmente como Hotokehime, ou dama do Buda, por volta de 1500 .

Os papiros indianos já indicavam a preocupação com problemas orais; assim como chineses, hebreus e fenícios, os Astecas, Maias e Incas enfocam a higiene bucal na utilização de raízes como medicamentos e incrustações de pedras preciosas colocadas em dentes com um tipo de cimento criado por eles.

No Brasil fazer prótese era atividade de dentista. Quando muito o dentista incumbia alguém, um auxiliar, um boy, para executar certas tarefas de prótese. A própria odontologia tinha seus problemas com os chamados práticos licenciados profissionais que praticavam a atividade sem formação superior. Até a Revolução de 1930, Getúlio Vargas resolveu, criar a profissão do protético com o decreto-lei referente à Odontologia, que citava o protético (AZEVEDO, 1963).

No ano de 1935, o governo deu um fim aos práticos licenciados, instituindo um exame de habilitação com certificado para quem quisesse exercer a odontologia. $\mathrm{O}$ protético só entra em cena em 1943, através do Departamento Nacional de Saúde Pública que criou a Portaria n.29, que obrigava o protético a prestar exame, passando por uma banca examinadora, a nível primário (BRASIL, 1985).O primeiro sindicato de protéticos foi criado em 18 de janeiro de 1954, funcionando na Avenida 13 de maio, centro da cidade do Rio de Janeiro. Podemos observar na figura 30, a ilustração por volta de 1910 de um laboratório. 


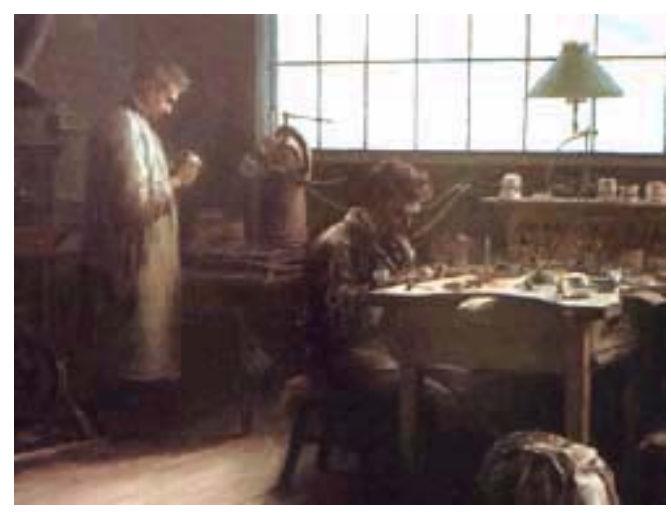

Figura 30 Ilustração por volta de 1910, Durif Bedel retratou o laboratório do seu marido, Dr. Durif. em Lion.

Fonte disponível em: $<$ http://www.protesetotal.odo.br Aceso em: 20 de dez.2003

O objetivo era derrubar a Portaria n.29, que com o tempo ficou obsoleta, pois as exigências para qualificação profissional eram mínimas. $\mathrm{Na}$ realidade, o dentista tinha medo e em razão disso, não permitia a ascenção do protético, temendo um antigo fantasma: o dentista prático. Não entendiam, portanto, que o lugar do protético é no laboratório, não no consultório (BRASIL, 1985). O Ministério da Educação, criou após, a Portaria $n .86$ na década de setenta, instituindo a obrigatoriedade do segundo grau para o técnico em prótese.

$\mathrm{Na}$ área odontológica é a prótese dentária que contribui junto com a parte clínica para repor elementos dentais e reproduzir a anatomia estética e fonética, proteger as estruturas remanescentes dando assim continuidade a função mastigatória (FORTUNA, 1968).

A prótese dentária se subdivide em várias partes: prótese fixa, que são todos os tipos de prótese dentária fixadas por meios químicos ou físicos e permanecem dessa forma até a remoção, dentre elas a jaqueta confeccionada em resina acrílica ou cerâmica recobrindo os dentes após preparos convenientes feitos pelos dentistas; implantes dentários artificiais fixados por pinos metálicos ou estruturas sustentadas pela parte óssea do maxilar e da mandíbula, reconstruindo, assim, um sistema biocompatível de fixação e sustentação dos dentes (CUNHA, 1968).

Há, ainda, a prótese removível: e que são os tipos de prótese que podem e devem ser removidas pelo usuário para uma perfeita higienização, pode ser uma prótese total (dentadura) ou parcial removível com estruturas metálicas fundidas (ponte removível, grampo, etc) ou em resina acrílica (com ou sem grampos de aço - fío ortodôntico).

Finalmente, há a prótese ortodôndica que é utilizada em inúmeros aparelhos e técnicas para que através da utilização destas forças se consiga, além de um sorriso perfeito, a solução dos diversos problemas causados por elementos desalinhados, dentro destas técnicas se encaixa a ortopedia facial: que age na parte óssea do maxilo ressolvendo rapidamente os casos indicados. Existem ainda muitos tipos de prótese. Que não estão sendo citadas aqui (GALVÃO NETO, 1990). 


\subsubsection{IMPLANTODONTIA}

O implante dentário passou por diversas fases, dentro de um processo progressivo de evolução. Cientificamente este processo evolutivo iniciou-se com os implantes em forma de parafusos helicoidais confeccionados com aço inoxidável, idealizado por Manlio Salvatore Formíggini por volta de 1943. Este é um marco da história da implantodontia, embora haja dados a respeito de uma espécie de raiz metálica de ouro idealizada pelo italiano Maggiolo por volta de 1807 (SOBRINHO, 2002).

Mais tarde, provavelmente por volta de 1930 surgiu o implante justa-ósseo. Em seguida destacaram-se os parafusos, as agulhas e as lâminas. Com o grande avanço da implantodontia, aqueles implantes utilizados nos primórdios vêm entrando em desuso diante da novidade desenvolvida. Valendo salientar que em grande escala os "antigos" implantes encontram-se em perfeito estado de normalidade, merecendo respeito por seu sucesso e integridade apesar da idade. Não sendo justo a remoção de um destes trabalhos com a finalidade única de penas substituí-lo por um tipo de implante contemporâneo (SOBRINHO, 2002).

A técnica da implantação consiste basicamente na colocação de bases artificiais inertes e aceitas pelo organismo, as quais substituirão as raízes e servirão de apoio para a porção coronária, desenvolvendo-se, assim, de forma artificial os dentes naturais ausentes. Por serem estruturas não vivas, inertes, biocompatíveis, esterelizadas e descontaminadas, torna-se um erro relacionar implante e rejeição. Pode-se falar em insucessos, que são desencadeados por alguns fatores como: inabilidade profissional, falha técnica, erro no plano de tratamento ou na confecção da prótese, ou por problemas sistêmicos ou deficiência na higiene por parte do paciente, enfim insucessos do tratamento, jamais rejeição ao implante em si (SOBRINHO, 2002).

Atualmente os implantes utilizados são confeccionados em titânio comercialmente puro, oferecidos com formas, tamanhos e diâmetros variados, possibilitando a reabilitação nas mais diversas estruturas anatômicas. A implantodontia é uma indiscutível realidade, digna de respeito e total credibilidade, visto que é uma opção e muitas vezes solução oferecida pelo dentista (SOBRINHO, 2002). Observe na figura 31 o implante dentário para fixação ponte móvel e dentadura.

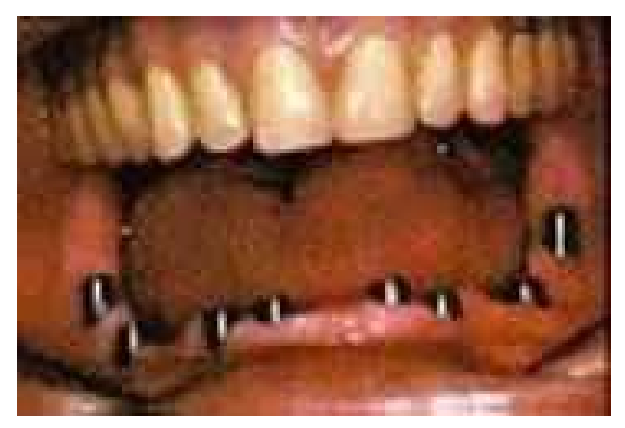

Figura 31 Implante dentário para fixação ponte móvel e dentadura.

Fonte disponível em: $<$ http://www.ibemol.com.br. Acesso em: 20 dez. 2003 
A aceitação por parte do maior beneficiado, o paciente, demonstrando alto nível de satisfação com a melhora do desempenho mastigatório e estético.

Outro fator proporcionado pela implantodontia é a manutenção de osso após a remoção do elemento dentário, no primeiro ano, ocorre uma perda óssea de $25 \%$ em largura e, em média de $4 \mathrm{~mm}$ de altura. Essa perda óssea é progressiva. Com a instalação dos implantes, a perda óssea cai para $1,5 \mathrm{~mm}$ no primeiro ano.

A instalação de implantes também melhora a estabilidade da prótese, produzindo maior conforto para o paciente. A prótese estável reflete em mais segurança psicológica e melhor sensação de bem estar no indivíduo. Hoje, uma pessoa com 65 anos de idade pode viver mais 16,7 anos. Trabalhos científicos têm mostrado que os idosos desta geração querem manter seus dentes na boca mais do que no passado, ou ter alternativas mais retentivas do que próteses totais convencionais. Os implantes melhoram a retenção das próteses. Isto permite que se faça enchimentos necessários nos flanges, corrigindo perdas horizontais de osso, sem prejuízo da retenção. As manutenções dos músculos da mastigação e expressão facial, também são vantagens associadas às próteses totais apoiadas em implantes.

Alguns autores acentuam que um dos critérios principais utilizados para se identificar um idoso bem sucedido, é pela manutenção de sua dentição natural, trazendo-lhe benefícios biológicos e sociais.

No Brasil, à semelhança dos diversos países do mundo, a população está envelhecendo rapidamente. A população idosa, considerada como aqueles indivíduos com mais de 60 anos, compõe hoje o seguimento populacional que mais cresce em termos proporcionais.

Se considerarmos do início dos anos oitenta até o final do século, observaremos um crescimento da população idosa em mais de $100 \%$. Até o ano de 2025 seremos a sexta maior população do mundo em números absolutos, com mais de 30.000 .000 de pessoas nesta faixa, representando quase $15 \%$ da população total. Estamos entrando na era dos idosos. A cada mês, o número de pessoas com mais de sessenta anos no mundo, aumenta em torno de 1.000 .000 de pessoas.

Neste contexto, a implantodontia se estabelece como peça fundamental do arsenal do cirurgião-dentista para responder a essas demandas da sociedade da era em que vivemos.

$\mathrm{Na}$ odontologia também existem as mulheres que trabalham, no desenvolvimento de materiais para a reconstrução óssea. Incluindo prótese metálica e materiais de enchimento, como as biocerâmicas. Marinalva Pereira, Glória Dulce de Almeida Soares, Cecilia Amélia de Carvalho Zavaglia, entre outras.

\subsection{APLICAÇAO DA BIOENGENHARIA NA OFTALMOLOGIA}

Entre os brasilindios, há oftalmias diversas; sobre este aspecto, descreve André Thevet: "há certas oftalmias que provêm do abuso da fumaça. Assim acontece entre os selvagens, que acendem fogo em várias partes e sitios de suas cabanas, alías bem vastas, pois nelas se reunem e hospedam numerosas pessoas. Sei, que nem toda oftalmia entre os indios provém da fumaça; mas seja como for, sempre se originam por vícios do cérebro, por qualquer meio que tenha sido ofendido"(CARDIM,1944).

Também sei "que toda a doença dos olhos é oftalmia, como acontece mesmo entre os habitantes da América, de que falo, porquanto muitos selvagens têm perdido a vista sem que tivesse sofrido nenhuma inflamação nos olhos". Trata-se certamente, 
conclui André Thevet (Pe. Capuchinho), de algum humor do nervo ótico, impedindo que o espirito da vista chegue até os olhos (THEVET, 1921)

A cegueira por doenças infecto-contagiosas, tais como a sífilis, a gonorréia, o tracoma, não existia no Brasil antes da descoberta; lesões oculares, com perda total da visão, assinalada por alguns cronistas eram, na sua quase totalidade, de origem traumática, principalmente por traumatismo de guerra. Dizemos na sua quase totalidade, porque os nossos silvícolas podiam estar isentos de certas afecções como o glaucoma, a catarata senil, e outras (CARDIM, 1944).

A conjuntivite catarral era bastante disseminada entre eles: "Os velhos e meninos são muito ramelosos", informa Ivo D'Evreux. A irritação querato-conjuntival consequente à fumaça das fogueiras, permanentemente acesas dentro das malocas, como acentuou Thevet, era o que mais incomodava aos índios (CARDIM, 1944).

"Notei ainda terem alguns índios a vista curta, especialmente os velhos, e notavelmente as mulheres, visto que depois dos trinta anos de idade tem a vista curta e fraca a ponto de não poderem mais tirar dos pés os bichos como fazem os rapazes e as moças". Trata-se de um fenômeno natural aos indivíduos de certa idade, a hipermetropia, ou, como dizem, "vista cansada"; quanto ao fato de serem as mulheres as mais precocemente vítimas de hipermetropia, isso se explica pelo próprio modo de vida dos silvícolas (GOMES, 1974).

"Vi zarolhos a que chamam uhessaue, porém, muito poucos, e vesgos que denominan. Thessauen, cheressuen estou vesgo, deressauen tu és vesgo" (PARDAL, 1937). Zarolhos e estrábicos, os havia, mas os casos de cegueira monocular eram, na sua totalidade, de origem traumática e não infecciosa.

A lupa usada inicialmente para aumentar as letras dos livros serviu de inspiração para várias experiências que culminaram nos óculos de hoje. Duas lentes sustentadas por uma armação, com hastes encaixadas atrás das orelhas.

Da armação de ferro a uma atual de dois gramas, os artesões experimentaram vários materiais para amenizar o peso sobre o nariz: osso, chifre, madeira, couro e estofado. As lentes mereceram atenção quando o vidro foi substituído pelo berilio e o cristal de quartzo, mais transparente. Foi fabricando lentes que os artesãos de vidro de Veneza fizeram sua fama.

Antes, os óculos eram amarrados na cabeça ou atrás das orelhas ou tinham um gancho de metal que era escondido por perucas. Somente no século 17 os óculos adquiriram função corretiva, quando os princípios da refração da luz foram ampliados no polimento das lentes. No século seguinte o físico Benjamin Franklin criou as lentes bifocais.

O Alemão Hermann von Helmholtz, em 1850, inventa o oftalmoscópio, aparelho para examinar o fundo do olho. No Brasil, uma das primeiras contribuições para o auxilio da visão veio com os colonizadores, os óculos que por muitos anos eram a única possibilidade de melhorar a visão.

Há muitas coisas que nossos olhos tem de fazer corretamente para termos uma visão perfeita. Se uma coisa não está correta, precisamos usar óculos. Mas os óculos precisam ser confeccionados especialmente para cada tipo de dificuldade. Os óculos funcionam curvando os raios de luz, fazendo com que os raios de luz atinjam diretamente sua retina. A retina transforma a luz em sinais que vão para o cérebro.

Nossos olhos funcionam como pequenas câmeras. Há uma lente que focaliza a luz. A luz tem que ser focalizada exatamente na retina para que nossa visão seja perfeita. A primeira coisa que pode estar errada é o comprimento do olho. Ele pode ser muito curto ou muito longo. Ou ainda, a córnea pode ter uma forma anormal. As lentes de nossos óculos ajudam as lentes de nossos olhos. Elas fazem com que a luz focalize 
exatamente a retina, de modo que possamos enxergar corretamente. Quando olhamos para objetos distantes, a lente se torna chata, através de pequenos músculos. Quando olhamos objetos de perto, os músculos fazem com que as lentes fiquem arredondadas e cheias. A idéia é manter tudo em foco.

A princípio o médico receitava o uso dos óculos, colírios, atualmente esta especialidade se aperfeiçou muito, lentes de contato, em várias cores inclusive, tudo para melhorar a aparência da pessoa.

Vou falar agora de algumas doenças oculares que afetam a grande maioria da população brasileira, e também lembrar que a aplicação da bioengenharia no globo ócular se dá através de duas formas simplesmente a aplicação do Laser e do uso do silicone, pois não se pode aplicar materiais biocompativeis internamente no olho.

Miopia - é uma condição onde geralmente o olho apresenta um comprimento axial maior que o normal. Assim, a imagem se forma antes da retina. A pessoas sente dificuldade principalmente para longe. São necessárias lentes corretivas para que a imagem forme na retina.

Hipermetropia - ao contrário da miopia, faz com que imagem se forme depois da retina, causando uma visão embaçada, principalmente para perto. $\mathrm{O}$ uso de lentes corretivas corrige o problema.

Astigmatismo - é causado geralmente por uma alteração na córnea. A superfície da córnea está irregular, fazendo com que os raios de luz cheguem na retina em regiões e focos diferentes. O astigmatismo causa piora da visão tanto para longe quanto para perto. A piora da visão acontece mais à noite.

Catarata - é uma opacificação da lente natural do olho: o cristalino. A medida em que essa opacidade acentua-se, as imagens não chegam na retina de forma clara. Os pacientes com catarata podem apresentar vários sintomas: visão borrada, sensibilidade à luz e ao ofuscamento, miopização e imagens distorcidas. A principal causa é o envelhecimento natural, mas outras causas são importantes: - traumatismo ocular certas doenças - medicamentos - doenças genéticas.

Ambliopia - é a baixa de visão em um olho que não se desenvolveu adequadamente na infância. Às vezes é chamado "olho preguiçoso". Isto ocorre apesar deste olho ser anatomicamente normal. O olho com pouca visão é denominado amblíope. A condição é frequente, acometendo 2 a $3 \%$ da população. Os pais precisam estar cientes desta condição para poder proteger a visão de seus filhos, pois a ambliopia precisa ser tratada durante a infância. O desenvolvimento de visão nos dois olhos é importante. Muitas profissões não admitem pessoas que tenham boa visão em apenas um olho. Caso a pessoa perca visão em um olho por trauma ou doença, é essencial que o outro olho tenha boa visão. Por todos estes motivos, a ambliopia deve ser detectada e tratada o mais precocemente possível.

Glaucoma - O olho humano possui líquidos no interior, que são produzidos e eliminados constantemente. Um aumento da produção ou diminuição da eliminação causa o aumento da pressão intra-ocular. $\mathrm{O}$ aumento da pressão ocular faz com que o nervo óptico comece a sofrer, causando perdas gradativas de fibras que o constitui. A perda dessas fibras significa o início do glaucoma e diversos exames podem ser realizados para comprovar o quadro clínico, como exame de fundo de olho e campo visual. Uma vez detectada a pressão alta do olho, é preciso usar colírios para o seu controle. Se a pressão não for controlada com medicamenteos, é necessária a cirurgia. Atenção: O dano já causado pelo glaucoma é irreversível. Todo o tratamento instituído somente mantém a visão, mas nunca melhorar.

Degeneração Macular Relacionada à Idade - DMRI. Essa doença causa uma alteração importante no fundo de olho (retina), causando baixa importante de visão. A 
DMS acomete paciente idoso, com perda progressiva de visão. Infelizmente não existe um tratamento para a DMS, mas algumas medidas podem ser feitas para tentar evitar a piora.

No Brasil 1990, o oftalmologista Paulo Galvão desenvolve técnica inédita que permite que uma mesma córnea dividida em duas, beneficie dois deficientes visuais.

A bioengenharia também ocorre quando por doença ou acidente se perde o globo ocular totalmente, então é colocada uma prótese de vidro para que não fique o vazio do globo ocular, fazendo então o efeito de beleza, e correção de estética.

Pela Lei no 10.211, de 23 de março de 2001 - Altera dispositivos da Lei 9.434, de 04 de fevereiro de 1997, que "dispõe sobre a remoção de órgãos, tecidos e partes do corpo humano para fins de transplante e tratamento". Apesar da aprovação recente desta nova lei, o Banco de Olhos continuará a obter doações efetivas (após o falecimento) somente mediante a consentimento dos familiares.

Não se pode fazer transplante de olho, pode-se somente ter um banco de olhos para que seje aproveitada a córnea, que é a única parte do olho que pode ser transplantada, salvando muitas pessoas da cegueira.

A Oftalmologia brasileira tem um grande desafio, neste início de século, propiciar um atendimento de qualidade a toda a população. Nesse sentido, a Universidade tem um papel primordial que pode ser resumido como Ensino, Pesquisa e Assistência.

\subsection{APLICAÇAO DA BIOENGENHARIA NA MEDICINA REGENERATIVA}

A bioengenharia abrange os processos que usam as células vivas autólogas, alogenéicas ou xenogenéicas como agente terapeutico. A biomimética usa moléculas e estruturas supramoleculares para induzir processos de regeneração mediados por células endógenas, ou combina o uso de células exógenas, mais frequentemente manupuladas ex vivo ou cultivadas in vitro.

No Brasil o Instituto do Milênio em Bioengenharia Tecidual e Biomimética tem como principal objetivo o estabelecimento no Brasil de capacitação científica e tecnológica para introduzir e desenvolver uma nova área médica a medicina regenerativa - que visa ao tratamento de pacientes com doenças crônico-degenerativas e traumáticas através de terapia celulares e/ ou teciduais. A área emergente de bioengenharia médica visa à substituição terapêutica de estruturas multicelulares, teciduais ou equivalentes a órgãos. Ela pode ser qualificada de "Medicina Regenerativa" pois visa ao reparo de tecidos lesados ou degenerados por substitutos funcionalmente $\mathrm{e}$ estruturalmente equivalentes. A Medicina regenerativa procura controlar e ampliar a capacidade natural de regeneração de tecidos. A regeneração mantém naturalmente a homeostasia tecidual, substituindo continuamente as células gastas.

Observe na figura 32, aplicação da medicina regenerativa. 


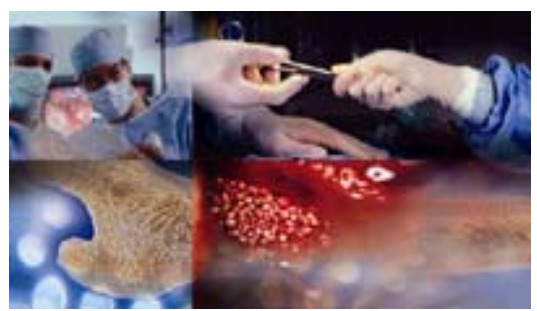

Figura 32 Aplicação da Medicina Regenerativa

Fonte Disponível em: $<$ http://www.imbt.org.br Acesso em 20 de dez. 2003

Os tecidos altamente expostos ao estresse externo são intensamente regenerados, como o epitélio intestinal ou cutâneo, assim como o tecido caracterizado pela alta taxa de renovação contínua, como as células sanguíneas. Por outro lado, ela pode eventualmente reparar, quando necessário, os tecidos lesados por trauma, doença ou senescência.

A Medicina Regenerativa busca criar condições ideais para o reparo e a substituição de tecidos lesados, fornecendo elementos celulares requeridos, os fatores de proliferação e diferenciação celular que podem garantir a geração de quantidade suficiente de células novas, e as estruturas supramoleculares que providenciam a organização espacial plenamente funcional de novos tecidos gerados e a sua integração sistêmica. $O$ conjunto dessas ações representa o campo de ação da bioengenharia, compreendendo a engenharia celular e tecidual, e a biomimética.

A importância crescente da Medicina Regenerativa é devida às modificações demográficas e sociais. $O$ aumento progressivo da idade média das populações humanas, e em particular das populações urbanas, gera a necessidade de garantir cada vez mais a qualidade de vida, compatível com um custo e uma carga social aceitáveis. $\mathrm{O}$ número de idosos até 85 anos irá triplicar nos próximos 50 anos, e o número de habitantes em senectude crescente (maior 85 anos) será multiplicado por seis, isso mundialmente. $\mathrm{O}$ segundo desses dois grupos (maior 85 anos) consome vinte vezes mais custos da assistência médica e duas vezes mais internação hospitalar do que o primeiro. As doenças degenerativas são a causa essencial e crescente dessa carga social, causando a deterioração da qualidade de vida e aumento dos custos da assistência médica.

Por outro lado, as populações jovens, vivendo em aglomerações de alta densidade, estão mais expostas a lesões traumáticas. Embora numericamente menos significativas essas lesões tem um altissimo custo social, gerando frequentemente pessoas jovens debilitadas ou permanentemente incapacitadas para uma vida normal e produtiva. Em populações urbanas do Brasil, as lesões traumáticas são a primeira causa tanto da internação hospitalar quanto da morte na segunda e terceira décadas da vida dos jovens.

Ambas as situações exigem terapias que possam preservar, melhorar, e/ou restaurar as funções teciduais. Contrastando com a produção de fármacos, antibióticos e vacinas que podem ser usados indistintamente por um grande número de habitantes, a Medicina Regenerativa é individual, dirigida especificamente a cada um dos casos atendidos, no seu contexto particular. Trata-se, portanto, de uma medicina individualizada, cuja ação pode envolver duas etapas, independentes ou associadas.

A manipulação ex vivo de células do próprio paciente, sua expansão, diferenciação e integração potencial em estruturas ordenadas superiores, que serão re- 
introduzidas nas regiões lesadas e integradas no processo de regeneração (bioengenharia ou engenharia tecidual)

A introdução, nas regiões lesadas, de estruturas supramoleculares, semelhantes aos elementos de matriz extracelular e mediadores intercelulares associados, facilitando a mobilização, expansão e integração de populações de células regenerativas internas, fomentando o reparo de lesões ou de regeneração e renovação de tecidos degenerados baseados em células, engenharia tecidual e biomimética.

Os dois processos se beneficiam dos avanços espetaculares da genômica, tendo potencialmente acesso às informações necessárias para definir o perfil do paciente, as necessidades de células envolvidas nos procedimentos planejados, e controlando a interação entre as células manipuladas, os tecidos internos e os elementos estruturais extracelulares.

Os conhecimentos mais amplos da área de pós-genômica são a base conceptual dessa parte de medicina, requerendo uma extensão de conhecimentos genômicos para os das organizações celulares, das interações e de funções celulares, e da função das estruturas supracelulares.Vale salientar que, nos últimos anos, o conceito do uso potencial da célula tronco-progenitora, de origem embrionária ou de organismo adulto, introduziu novas perspectivas em tratamento celular de patologia tecidual. Assim, a possibilidade de cultivo de células progenitoras embrionárias (embryonic stem cells ESC) humanas a partir de blastocístos obtidos por fecundação in vitro, permitiu propor transplantes de células embrionárias totipotentes em tecidos degenerados, conseguindo uma regeneração in situ de populações celulares funcionais.

Aplicações clínicas já foram obtidas em tratamento de doenças degenerativas do sistema nervo central. Enquanto os implantes nos sitios imunologicamente privilegiados não encontram obstáculos maiores, o uso de células embrionárias alogenéicas enfrenta o problema de rejeição imunológica. Uma das soluções atualmente estudadas é o transplante do núcleo de células do receptor para as células embrionárias cultivadas, gerando assim clones de células autólogas com caracteristicas de células progenitoras embrionárias totipotentes.Uma alternativa foi vislumbrada com estudos recentes, mostrando que o organismo adulto possui uma reserva de células troncoprogenitoras pluripotentes.

A fonte mais ampla é aparentemente a medula óssea, cujas células tronco mostram a capacidade de diferenciação praticamente totipotente, incluindo (em modelos animais) uma capacidade de diferenciação em uma ampla gama de células de origem mesenquimal, endodérmica e ectodérmica. Como essas células podem ser facilmente colhidas, e potencialmente cultivadas ex vivo, esse novo conceito abre amplas possibilidades de seu uso em medicina regenerativa, nos sitemas autólogos e, portanto, isentos de problema de rejeição imunológica.

Além das células progenitoras medulares, vários tecidos guardam a reserva interna de células pouco diferenciadas com capacidade de regeneração. As células satélites de fibras musculares esqueléticas são um dos exemplos clássicos, assim como pericitos pericapilares. Estudos recentes mostram que, embora engajada em uma via, ou em um número limitado de vias de diferenciação, como por exemplo, a obtenção de condroblástos e osteoblástos a partir de células satélites musculares ou de preadipócitos.

Resultados semelhantes foram obtidos com células do sistema nervoso central adulto, podendo dar origem a neurônios e astrócitos. Essas observações abrem uma perspectiva ilimitada para a medicina regenerativa, cujos limites parecem ser cada dia mais amplo.A possibilidade de diferenciação alternativa de células progenitoras, induzida por ambiente tecidual in situ ou ex vivo, levanta a segunda questão atualmente relevante: quais os mecanismos moleculares que determinam ou induzem a 
diferenciação de células tronco-progenitoras em um fenótipo particular, e qual a relação entre os fenômenos algo oposto e complementar de proliferação e diferenciação celular, ambos requeridos para a aplicação em medicina regenerativa.

Conhecimento de fatores de crescimento e de diferenciação celular secretado para o ambiente intercelular, e de elementos estruturais intercelulares que compõem o "ambiente tecidual", mostra cada vez mais a importância de complexos multimoleculares organizados.Essas estruturas de ordem de organização superior adquirem as propriedades novas que não representam mais o somatório das propriedades de seus elementos isolados. A complexidade dessas estruturas representa $\mathrm{o}$ desafio para a biomimética funcional, que deseja criar as condições adequadas para a mobilização de células pluripotentes endógenas, ou introduzidas após a amplificação e manipulação dessas células ex vivo.

As inovações conceituais e tecnológicas representam, pois, o trilho central do desenvolvimento da bioengenharia tecidual. Diferente da Biotecnologia Molecular e Genômica, os modelos do crescimento da bioengenharia e biomimética ainda não estão estabelecidos. Nos Estados Unidos, mais de 90\% de investimentos nessa área, que somaram na década de 90 mais de três bilhões dólares, com um crescimento em 2000/2001 superior a 1,5 bilhão de dólares, são oriundos da área industrial privada.A análise de perfil dos investimentos mostra qua a área privada investe essencialmente em processos já estabelecidos. As cinco maiores companhias americanas de engenharia tecidual têm como o produto principal os substitutos de pele.

Visando corrigir essa falta de visão prospectiva, as agências públicas federais dos Estados Unidos estão aumentando os seus esforço, tendo investido na mesma década (de 90) 83,2 milhões dólares, dos quais 19,3 dólares em 2000. No Brasil, a demanda para os procedimentos médicos de bioengenharia tecidual origina-se tanto na área hospitalar privada quanto em centros médicos públicos. Para a rede privada, ela representa a possibilidade de oferecer um tratamento de alta complexidade a um público qualificado com poder aquisitivo compatível com o custo alto e habituado às despesas envolvendo tratamento e prevenção médica.Para a rede pública, a demanda origina-se na obrigação de atender a procura e resolver patologias crônicas complexas e lesões graves, que geram para a sociedade um custo extremamente elevado.

Embora exista o interesse da rede privada nessa área, a sua capacidade e vontade de investimento são limitadas. No Estado do Rio de Janeiro, $80 \%$ de atendimentos médicos classificados pelos SUS como de "alta complexidade" são realizados na rede pública principalmente no Hospital da Universidade Federal do Rio de Janeiro - UFRJ e nos Institutos Nacionais do Câncer e de Traumato-Ortopedia.

A situação é semelhante em outros estados. Seguindo a experiência dos Estados Unidos, cabe ao Governo Federal prever os mecanismos de interação entre as partes interessadas e, mais uma vez, fornecer o apoio adequado ao grupo já instalados no país que possuem um capital elevado em recursos humanos.

$\mathrm{Na}$ engenharia de tecidos, área de conhecimento dentro da bioengenharia que tem de expandido consideravelmente nos últimos anos.

O Objetivo desta nova área é aplicar conceitos de engenharia na produção de estruturas híbridas, composta de materiais biológicos (como o colágeno ou mesmo células) associados a elementos sintéticos (como polímeros biodegradáveis). 


\section{DISCUSSÃO}

As doenças infecciosas como a tuberculose, osteomielite e em muitas cirurgias que eram praticadas não se usava nada de implante, de nenhum tipo. As luxações congênitas quadril eram devido à maneira de como as crianças eram embrulhadas nos cueiros - os italianos utilizavam essa técnica para imobilizar a criança. A diminuição deste tipo de tratamento aconteceu devido a prática da cesariana - método utilizado para o nascimento de bebes - isso foi fundamental, pois a pratica dessa cirurgia era totalmente coberta pelo Sistema Único Saúde - SUS, e houve um interesse nuito grande das mulheres para a prática deste método. Quando a cesariana era praticada, a paciente não corria o risco de ter filho com paralisisa cerebral, pois a cesariana contribuiu para a não utilização do fórceps - método utilizado no auxílio do parto normal e que retirava o feto a força - isso contribuía para que ocoressem as paralisias cerebrais.

Outro fator importante foi a necessidade da vacina Sabin, o uso das gotinhas que imunizavam as crianças, fazendo com que o número de casos de poliomielite se reduzissem muito na época. Hoje está totalmente erradicada do Brasil esta doença graças à vacinação.

A bioengenharia surgiu utilizando-se da tecnologia atual para o paciente que era gessado por noventa dias após uma fratura; atualmente após uma fratura em vinte dias o paciente está caminhando e nem percebe que sofreu uma cirurgia. Isso se dá graças a uma boa fixação, pois é ela que faz com que tudo se estabilize, tormando a recuperação mais rápida.

A bioengenharia é definida de várias maneiras, o que é normal se consolida, a custa de tempo, ou não se consolida. Com as alterações de DNA, o tratamento da célula é muito amplo e a engenharia trabalhada nas células é a bioengenharia que é trabalhada nos tecidos. Para se obter uma resposta maior se utiliza a biogenética. Como visão de futuro, a bioengenharia cresceu muito e é, sem dúvida nenhuma, o nosso futuro; na natureza, nós fomos criados para vivermos uma média de cinqüenta anos. Com a bioengenharia, se tem o prolongamento da vida. Nós, humanos, não estamos, por exemplo, preparados para conviver com a artrose, criada pela sociedade contemporânea, aonde a qualidade de vida vai nos dar para a parte não programada relativamente setenta a oitenta anos.

Pesquisas em bioengenharia encontram-se ainda em estágio inicial ainda com poucos grupos se formando e na maioria isoladamente. Sendo uma área de expansão, necessita de pesquisas nas mais diversas áreas que ela representa, principalmente, em setores estratégicos de produção e síntese biológica e/ou equipamentos são produzidos, são provenientes de importação.

Devido ao elevado custo dos equipamentos e materiais médicos, a bioengenharia é uma área prioritária para o Brasil. Como exemplo, a cardiologia no Brasil foi possível graças ao apoio da bioengenharia, tornando os materiais e equipamentos acessíveis a qualquer centro médico.

As multinacionais da área de produtos médicos hospitalares e odontológicos são na grande maioria indústrias de montagens e processos finais, com testes e esterilização de produtos e equipamentos.

Sendo que as empresas somente uma minoria tem parceria com universidades, utilizam tecnologia própria como um todo e utilizam também de tecnologia importada. Sendo que na grande maioria das empresas não existe núcleo de desenvolvimento de 
pesquisas voltado para a bioengenharia e uma minoria de empresas possui núcleo de desenvolvimento em pesquisas voltadas para a bioengenharia.

Para avaliar o problema das indústrias nacionais na área, devemos recorrer a análise de cada uma em relação à história da evolução da área da medicina a que se aplica o produto final, gerado pela indústria, o que, todavia, na grande maioria, surgiram de ex-funcionários de representações de produtos e equipamentos importados.

Com profissionais especialistas em Engenharia, técnicos, medicos, informática, mecânica, ortopedia, biomedicina, odontologia, biomédica, bioquímica, textil. As indústrias nacionais da área, quase na sua maioria, nasceram de pequenos produtos substituindo importações e desenvolvidos para atender a realidade nacional, em termos de custos e recursos. Através da pesquisa, muitos proprietários fizeram observação de que gostariam de poder estar desenvolvendo produtos de materiais bioabsorvíveis, não aplicáveis, titânio, polímeros e biomateriais, querendo inovar em relação aos próprios produtos e desenvolver novos, com o uso de novas tecnologias.

Afirmam que os seus produtos, na sua maioria o mercado absorve toda a produção, alguns não conseguem colocar no mercado interno e exportam. Com um número de funcionários nas empresas que se aproximam de dois a cento e setenta, que trabalham especificamente com bioengenharia. Para que seus produtos sejam melhorados, trocam idéias com clientes, técnicos, enfermeiras, médicos, consultoria, fornecedores, publico consumidor, assessores técnicos, pessoal interno, universidades, profissionais da saúde, hospitais.

O início da bioengenharia no Brasil ocorreu em fatos isolados antes do século $\mathrm{XX}$, mas foi somente no início deste século que a bioengenharia se revelou como ciência no Brasil. Primeiramente, na cardiologia seguida pela ortopedia, que teve sua época áurea em 1970: os acidentes automobilísticos e a diminuição das doenças congênitas explodiram na ortopedia e isso fez com que a especialidade melhorasse. Antes de 1970, só existia a paralisia cerebral, obstetrícia e a poliomielite. Na realidade, o HC-SP, era para a cura da poliomielite. Só se trabalhava com a biomecânica que era ligada a fisiologia muscular onde se trocava o músculo de lugar, Não se trabalhava com placas, pregos, parafusos, era só a retirada dos tendões.

O cirurgião drenava o local da cirurgia e o restante o antibiótico curava, evitando a aplicação de injeções de 6 em 6 horas.O paciente era medicado e em sua residência completava o tratamento com o uso dos antibióticos. As doenças congênitas melhoraram, pois não se utilizavam nos bebês os cueros, no nascimento não se tinha problemas e com isso iniciou-se a era da mecânica.

A utilização dos parafusos em cirurgias iniciaram-se com os pinos de rosca, que eram um absurdo ao serem implantados, o osso recebia esse parafuso necrozava e com isso o parafuso se soltava. Quando se utilizavam placas e parafusos a grande maioria das placas entortavam, pois eram de um material de quinta categoria. A melhora lenta e progressiva deu início com a prótese de Lage considerado revolucionária na ortopedia.

Flávio, médico ortopedista, criou uma excelente oficina ortopédica dentro do Intituto de Ortopedia em 1966, pois ouviu falar que as fraturas de ossos longos durante a II Guerra eram então fixadas por pinos intramedulares e que eram de um autor alemão, como esse método era mantido como um segredo de estado, pois permitia a volta dos soldados ao campo de batalha em menos de vinte dias, o método era utilizado em elementos de alta especialização, os aviadores e páraquedistas.

Não foi possível ao Prof. Flávio ver essa cirurgia sendo realizada, e também dos detalhes em pormenores, fez contato com oficina ortopédica e teve apoio, criando o seu próprio pino intramedular com o qual em 1953, defendeu sua tese de livrre 
docência. O Tratamento cirurgico em fraturas de ossos longos com o pino de Kinser, além disso, construiu modelos, teve ídeias que somente quinze anos passados (1980 a 1987) os EUA as fraturas de fêmur instável com tendências vivas eram imobilizadas com um modelo de pino original no momento da cirurgia antes da perda da redução fixação, eles introduziram dentro da haste, luz do pino dentro da qual havia duas aletas as quais não se abriam e evitava a rotação (o autor que lançou essa maneira de fixação era igual a do brasileiro Godoy Moreira) método esse que no Brasil o Prof. Flávio já praticava desde 1952. E nunca patenteou. Godoy Moreira, médico ortopedista, tinha uma oficina própria, que produzia o seu próprio material cirurgico para o colo do fêmur, que ficou conhecido mundialmente.

Foi criado o LIM centro de formação pesquisa, engenharia de materiais, corossão de implantes, foi quando houve a transferência das cadeiras básicas da faculdade para o Butantan e o HC, o prédio ficou vazio, a academia de policia PM tinha um prédio e se houvesse outro vago eles coupavam. Dr. Rossi resolveu fazer do prédio um laboratório, conhecedor da biomecânica do aparelho locomotor, tinha máquina para quebrar ossos, resistência a tração, foi colhendo ossos de cadáver, cabeça, fêmur, diáfise, deixando tudo no porta malas do carro de uso pessoal, uma carga de mais de cem ossos que transportava de um lado a outro. Produziam materiais para outras escolas.

Com a construção do prédio do HC, início em 1942, e funcionamento em 1953, a vida do hospital mudou. No período do pós Guerra operava-se tudo, englobando como atividade cirurgica o que anteriormente era gessado. $O$ ambulatório equipado funcionava de portas abertas, radiografia, ressônancia, megatoscópio, resultado de trabalho de quarenta anos, que foi copiado por Adib Jatene em uma visita feita ao hospital. O setor de higienização, pois muitos pacientes eram dispensados por estarem com piolhos, isso gerava custos.

No interior do Estado de São Paulo, Ribeirão Preto em 1977, um grupo de pesquisas em bioengenharia ativamente iniciou desenvolvimentos em ortopedia, em São Carlos no ano de 1979 foi criado um curso como interdisciplina em parceria com FMRP/EESC e Matemática. Com o tempo, a matemática saiu do grupo, sendo que o objetivo do departamento incluia a matemática para se trabalhar modelamento, os modelos para que se pudesse trazer mais conhecimentos à área biológica. Posteriormente, a química completou a interdisciplinaridade passando a ser EESC/FMRP/IQSC o único curso com esta característica no Brasil.

Os segmentos da bioengenharia envolvem física, eletrônica, medicina, ultrasom dividindo-se em partes que se complementam os desenvolvem as próteses para a ortopedia e parte de materiais, engenharia de tecido, cardiologia. São os biomateriais que apontam para o ideal, nos tecidos biológicos em amostras implantadas em animais que não tiveram rejeição ao implante, passaram então para as próteses de quadril, onde os polímeros biocompatíveis adquirem caracteristicas muito próximas da matriz orgânica do osso, não só no colágeno, e sim fazendo com que o osso penetre no material, havendo assim uma total biocompatibilidade, dependendo ao arranjo a molécula monômera.

Em Araraquara, existem desenvolvimentos isolados em biomateriais aplicados em odontologia. O biomaterial deve apresentar certos requisitos essenciais como: biocompatibilidade, biofuncionalidade, bioadesão, propriedades mecânicas compatíveis àquelas do osso, processabilidade, resistência à corrosão e preços condizentes com a realidade brasileira.

Exige-se que o osso seja tencionado; na prática da bioengenharia intenciona-se forçar o trabalho do osso, senão ocorre reabsorção e a prótese com o tempo fica frouxa. 
O osso trabalha se solicitado, regenera e absorve, caso não seja tencionado ele só reabsorve (DUARTE). Metais como o titânio é largamente utilizado como material de implantes porém o seu processamento é feito em atmosfera controlada, o que encarece tremendamente o seu custo.A perfeição tecnológica de um material de implante é alcançada quando se mistura estequiometricamente os metais titânio, vanádio, alumínio porém o seu processamento também é feito em atmofera controlada encarecendo o produto.

Segundo Morris Cohen,"Os materiais são substâncias com propriedades que as tornam úteis na construção de máquinas, estruturas, dispositivos e produtos" Os materiais podem ser classificados em: materiais metálicos, materiais cerâmicos, materiais poliméricos, materiais compósitos. Além destes, temos os materiais semicondutores, os materiais supercondutores, os polímeros condutores e os silicones.

Os materiais metálicos têm sido investigados visando a sua aplicação como implante. Metais nobres como o ouro, a prata e a platina foram testadas inicialmente e logo descartados em função de suas propriedades mecânicas não serem adequadas. Os materiais metálicos de uso comum na atualidade abrangem três grupos: os aços inoxidáveis, as ligas a base de cobalto e as ligas a base de titânio. Dentre estes três grupos, os biomateriais mais utilizados são aqueles a base de titânio.

A utilização de materiais sintéticos, para a substituição ou aumento dos tecidos biológicos, sempre foi uma grande preocupação nas áreas médica e odontológica. Para este fim, são confeccionados diversos dispositivos a partir de metais, cerâmicas, polímeros e mais recentemente compósitos. Na realidade, nem sempre são novos materiais no sentido estrito da palavra, são materiais dos quais se utilizam novas propriedades obtidas mediante diferentes composições químicas ou processos de fabricação.

Lage desenvolveu, 1951, uma placa em aço especial de formato em L. Após sete dias deixava o hospital, com setenta e cinco dias após a cirurgia o paciente poderia caminhar, não sofria escaras, não tinha problemas respiratórios, enfim começava a viver. A placa de Lage passou a ser utilizada em todo o Brasil, o que se esqueceu foi de patentear sua descoberta - mesmo porque na época não se fazia patente.

Lage coordenava a confecção de suas placas no torno da oficina do Hospital Anchieta, o qual foi sócio fundador, e Napoli fazia a parte cirúrgica. Os princípios de Lage são intocáveis o problema da época era encontrar o material com a biocompatibilidade desejada.

A utilização do raio Laser na interação, terapeutica e diagnóstico nas áreas de: biomedicina, odontologia, oftalmologia, oncologia, fotodinâmica, transcutâneo, podendo ser utilizado em alta potência para terapia e baixa potência para terapia e diagnósticos, sua aplicação iniciou-se desde 1998.

O modelo de Ultra-som desenvolvido como primeiro trabalho realizado pela interunidades EESC/FMRP, Efeitos Biológicos do Ultra-som, desenvolvido o método da estimulação ultra-sonica da regeneração óssea o qual demonstrou experimentalmente a aceleração de processo de reparo ósseo em fraturas com retardo de consolidação e pseudoartrose.

Quando se refere ao material ideal para ser implantado, no passado a falta de material específico para aplicação em implantes fazia com que se utilizassem o que se tinha em mãos, a grande contribuição começou a bolar placas para fixação em fraturas feitas em bronze, cobre, sendo que o próprio mecânico confeccionava, cabia ao médico implantar e quantas seqüelas foram deixadas.

O gráu de exigência na década de oitenta era de má qualidade, o material de segunda e não se tinha uma rigorosa inspeção. Atualmente, o material é de melhor 
qualidade, muitos erros foram percebidos e corrigidos ao longo do tempo chegando-se a conclusão que o material não era tão importante e sim a habilidade da técnica utilizada, o domínio da técnica é o que importa.

É preferível fazer cópia de produtos importados do que desenvolver novas pesquisas. Quando custa caro lá for a pesquisa já está embutida no preço, já vem testado, a idéia pronta e descutida, tem custo e se torna barato.

O profissional engenheiro biomédico não é coadjuvante do médico e sim um profissional que irá atuar com a parte eletrônica do hospital, sendo que para o médico a parte biológica. Pois é muito comum nos sub-solos de hospitais monte de equipamentos empilhado, sendo que as vezes é simplemente não saber como utilizar a máquina, equipamentos caros, importados, inúteis e os pacientes precisando serem atendidos.

A Indústria nacional é desistimulada a fazer materiais novos para serem aplicados no mercado, pois não tem a garantia de vendas e como normalmente trabalham com materiais importados, preferem não se arriscar.

Estamos chegando ao limite do tecido, a cicatrização é mais rápida é só passar o conceito do tecido para celular é celular. É uma pena que vai se acabar a arte do cirurgião, vai haver a retirada do osso, coloca-se a prótese e está pronto tudo muito rápido. Hoje devido a utilização da anestesia pode-se manter o paciente até por 24 horas em uma cirurgia. 


\section{CONCLUSÃO}

Os primeiros desenvolvimentos tecnológicos que podem ser relacionados com a bioengenharia se deram com o desenvolvimento e a implantação de vacinas, fato este considerado como o primeiro passo desta ciência, porém sem nunca ter utilizado o termo bioengenharia.

A partir de 1962 o Instituto Brasileiro de Ensino Ciência e Cultura - IBECC, resolveu importar tecnologia para acelerar a renovação do ensino de ciências no Brasil aproveitando o surgimento de novos currículos que recentemente foram implantados nos Estados Unidos. Aprovetando então a interdiciplinaridade surgiu bioengenharia/engenharia biomédica no Brasil. indústrias.

Existe um afastamento, até então não justificado, entre universidade e

A comunicação entre os grupos/centros que desenvolvem bioengenharia no Brasil é escassa. Necessitando que se pratique troca de experiências/informações entre si.

Falta divulgação dos trabalhos de bioengenharia. $\mathrm{O}$ termo não é bem aceito pelos pesquisadores, divulgando o produto e não a ciência. 


\section{REFERÊNCIAS BIBLIOGRÁFICAS}

ABREU, L. B. 1950. Padronização em cirurgia ortopédica e traumatológica. Revista Hospital das Clínicas.n.5.

ABREU, M. de. 1944. Tratamento das osteomielites. $6^{\circ}$ Congresso Brasileiro Ortopedia e Traumatologia,

ABREU, M. de.; RÜCKER, H.1950 . El tratamiento de las fracturas diafisárias del femur por el metodo de Küntscher. Rev. Ortop. Y Traumatol. n.20.

ABTO,2002. Associação Brasileira Transplantes de Órgãos, site em http://www.abto.com.br

ALMEIDA, M. de. 1998. A República dos Invensíveis: Emilio Ribas, microbiologista e saúde pública em São Paulo (1898-1917). Dissertação de Mestrado, São Paulo: FFLCH-USP.

ALMEIDA, O.de. 1934. A propósito do "caso da Universidade”. Belo Horizonte: Gráfica Queiroz Breyner Ltda.

ALVES, J. J. A.1989. A Ciência: as atividades que se fizeram em seu nome (19201950). Tese de Doutorado, São Paulo: FFCL-USP.

ANDRADE, A.J.P. de. 2001.Aron José Pazin de Andrade, Engenheiro PhD. do Instituto Dante Pazzanese de Cardiologia - São Paulo. Entrevista pessoal concedida a Ana Maria Antonio, no IDPC em São Paulo. Em Bioengenharia aplicada a Cardiologia no Brasil. 02 fitas Cassete.

ANTUNES, J. L.; NASCIMENTO, C. B.\& NASSI, J. C.1982. Laboratório de saúde pública (1892-1929); cronologia histórica. In: ANTUNES, J.L. et al. (Orgs) Instituto Adolpho Lutz: 100 anos do laboratório de saúde. São Paulo: Ed. I. Adolpho Lutz/ Letras \& Letras.

ARAUJO, A. 1940. de. Costelas cervicais. Revista Brasileira Ortopedia e Traumatologia n.2.

ASSEF, A.L.V.; SCHRÖDER, J.C. 1998. Materiais de enxertos utilizados para levantamento de seio maxilar. BCL,5(2):49-61.

AXHAUSEN, G. 2002.(1887-1960) alemão site http://www.ortopediars.com.br/history, acessado em janeiro.

AZEVEDO, F. de.[ 18...? ](Org) As ciências no Brasil. 2.v.São Paulo. Ed. Melhoramentos.

AZEVEDO, F. 1963. A cultura brasileira: introdução ao estudo da cultura no Brasil. Brasília. Ed. Universidade de Brasília.

AZEVEDO, M. 1985. Sociedades fundadas no Brasil desde os tempos coloniais até o começo do atual reinado. Revista do IHGB, 71. 
AZEVEDO, T. de. O Vegetal como alimento e medicina do índio. Separata da Revista do Arquivo Municipal de São Paulo. 76: 270,141.

AZEVEDO,T. 1949. Povoamento da cidade do Salvador. Bahia. Tip. Beneditina Ltda., p.230.

BADOU, G. 1994. Le corps défendu - quand la médicine dépasse les bones. Paris. Éditions Jean-Claude Lattés.

BARROS e CASTRO, A. 1979.Em torno à questão das técnicas no escravismo. Cadernos EIAP, 1. ( Série Desenvolvimento Agrícola)

BATALHA, E. de S. C.; CARVALHO, E.T.; ANDREUCCI, M.; Brasil, R.[19...?] $O$ tratamento das fraturas dos ossos da perna pela fixação bipolar com fio de Kirschner. Rev. Hosp. Clínicas. São Paulo.

BAUMER, M.A. 2002. Manoel Amaral Baumer, proprietário da Empresa Baumer. Entrevista pessoal concedida a Ana Maria Antonio em 05 de junho, na empresa Baumer cidade de Mogi-Mirim-SP. Sobre empresas que produzem bioengenharia no Brasil. 02 fitas Cassete.

BENCHIMOL, J. L. \& TEIXEIRA, L. A.1993. Cobras, Lagartos \& Outros Bichos: uma historia comparada dos Institutos Oswaldo Cruz e Butantan. Rio de Janeiro: Fiocruz/UFRJ.

BENCHIMOL, A. B.; SCHLESINGER, P. (ed) 1978. Cardiologia Enciclopédia Médica Brasileira, vols 1 a 2 - Rio, Livro Médico Ltda.

BEM-DAVID, J. 1974.O Papel do Cientista na Sociedade. São Paulo: Pioneira.

BERG, E.H.; GOODMAN, S.E.; STUCKEY, J.H.; NEWMAN, M.M.1957. Total Replacement of the Mitral Valve S. Forum, 8:363-7.

BISCEGLI, J. F. 2001. José Francisco Biscegli, engenheiro Industrial, Diretor do Centro Técnico de Pesquisas e Experimentos do Instituto Dante Pazzanese de Cardiologia, Diretor da Divisão de Bioengenharia da Fundação Adib Jatene. Entrevista pessoal concedida Ana Maria Antonio no IDPC em São Paulo, Bioengenharia na Cardiologia e no Brasil.

BISCEGLI, C. I. 2003. Clóvis Isberto Biscegli, engenheiro Embrapa Instrumentação Agropecuária - Ministério da Agricultura, Pecuária e Abastecimento - Centro Nacional de Pesquisa e Desenvolvimento de Instrumentação Agropecuária de São Carlos Entrevista pessoal concedida a Ana Maria Antonio, na Embrapa. Bioengenharia no Brasil.

BITTAR, A.C.M. 1950. Luxação congênita do quadril. Estudo dos casos do Hospital Jesus, $9^{\circ}$ Congresso Brasileiro Ortopedia e Traumatologia. 
BLAKE, S.1943. Diccionário Bibliográfico Brasileiro, Rio de Janeiro: Imprensa Nacional.

BLEICH, A.R.1960. The Story of. X-rays from Rontgen to Isotopes New York, Dover Plub.

BLESSMAN, G. 1946. Fraturas e luxações intrinsecas do pé. $7^{\circ}$ Congresso Brasileiro Ortopedia e Traumatologia.

BLOCH, M. 1976. Introdução à história. Lisboa, Europa-América/mem-Martins.

BOBBIO, A. 1970. Fragmento atualmente no Peabdy Museum of Archeology and Ethnology da Universidade de Harvard. São Paulo - Brasil.

BRASIL, Leis Decretos etc.1985. Constituição Politica do Império do Brasil, Jurada em 24 de março de 1824. In SILVA, H.- As Constituições Brasileiras. Rio de Janeiro. Ed. Globo.

BRASIL. Leis, Decretos etc 1891- Constituição da República dos Estados Unidos do Brasil. Promulgada em 24 de fevereiro de 1891.

BRAUNWALD, N.S.; COOPER, T. 1960. Morrow AG-Complete Replacement of the Mitral Valve Sucessful Clinical Application of a Flexible Polyurethane ProsthesisJ.Thorac Cardiov, Surg. 40:1-11.

BRITTO, A. de. 1940. A Odontologia através da Legislação Federal. Rio de Janeiro. Imp. Nacional.

BURCH, G.E. De Pasquale, N.P.1964. A History of Eletrocardiography. Chicago, Ed. Year Book.

CASTIEL, L. D. 1998 "Apocalypse.... now? Molecular epidemiology, predective genetics tests, and social communication of genetic contents". Cadernos de Saúde Pública, 15(1): 73-89.

CALMON, P.1967. A primeira médica. O Cruzeiro, Rio de Janeiro, 18 nov.

CAMARGO, F. P. de.; WERTHEIMER, L. G. 1952. Fifty Years of Progress in Orthopaedics and Traumatology in Brazil. São Paulo. BRAZIL, Vol.34-A. n.3. July.

CAMENIETZKI, C. Z. 2000. A Companhia de Jesus e a ciência na América portuguesa entre 1663 e 1679. III Seminário Nacional de Historia da Matemática. Anais... Vitória.

CAMPOS, E. de S.1941. Instituições Culturais e de Educação Superior no Brasil. Rio de Janeiro: Imprensa Nacional.

CAMPOS, E. de S. 1944. Instituições culturais e de educação superior no Brasil. Rio de Janeiro. Imp. Nacional 
CAMPOS, O. P.1950. O problema da paralisia infantil no Brasil. $9^{\circ}$. Congresso Brasileiro Ortopedia e Traumatologia.

CAPUANO, Y.2002. Matris Anima Curant - As Pioneiras Médicas: Maria Augusta Estrela e Rita Lobato. São Paulo. Scortecci: Línea Médica.

CARBONELL, C. O. 1987. Historiografia, Lisboa, Teorema.

CARDIM, F.1944. Tratado da terra e gente do Brasil. Rio de Janeiro. J. Leite \& Cia. Ed.

CARVAlHO, J. M. de.1978. A Escola de Minas de Ouro Preto: o pêso da glória. São Paulo. Companhia Editora Nacional.

CARVAlHO, J. M. de.1980. A Construção da ordem: a elite politica imperial. Rio de Janeiro: Ed. Campus, ( contribuições em Ciência Sociais,8)

CASTRO, A.B. de.1979. Em torno da questão das técnicas no escravismo. Cadernos do EIAP, 1. ( Série Desenvolvimento Agrícola).

CASTRO, C. de. M.1978. A prática da pesquisa. São Paulo. Mc Graw-Hill.

CAVALCANTI, I. de L.; THOMPSON, G.; SOUZA, N. de.; BARBOSA, F.S.1962. Pulmonary Hypertension in Schistosomiasis, Br. Heart J. 24:363.

CHAGAS, C. 1981. Coletânea de Trabalhos Científicos - Coleção Temas Brasileiros. Vol.6 - Org. Aluisio Prata, Ed. Univrsidade de Brasília.

CHAGAS FILHO, C.1968. Histórico sobre a Doença de Chagas, In; Cançado, Rio de Janeiro. Ed. Doença de Chagas Belo Horizonte, Universidade Federal de Minas Gerais. p.5.

CHAVES, D. A.1948. Contribuição ao estudo da coxa-plana. Rio de Janeiro. Emp. Gráf. J. Comércio.

CID-10 Classificação Internacional de Doenças. 1975. Adaptada para uso em processamento de dados.Editora e distribuidora Sagra - Baseada nas recomendações da nona conferencia de Revisão, e adotada pela vigésima Assembléia Mundial da Saúde.

CINTRA, A. B. de. U.1949. Doenças ósseas metabólicas. São Paulo, Piratininga Ltda.

COCKLIN, J. 1971. Autologous bone grafting-complications at the donor. site J. Bone Joint Surg. 53B153.

COHN, L.H. 1993. The First Successful Surgical Treatment of Mitral Stenosis. The Toth Amiversary of Elliot Cutler's Mitral Commissurotomy. Ann Thorac Surg. 56:1187-90.

COSTA, A. de A. L. da. 1928. Direito profissional do cirurgião-dentista. São Paulo. Acadêmica. 
COSTA, A.1981. As idéias Fundamentais da Matemática e outros Ensaios. São Paulo: Ed. Convívio.

COURNAND, A.; RILEY, R.S.; BREED, E.S; BALDWIN, E. de F.; RICHARDS Jr, D.W.1945. Meassurement of Cardiac Output in Man Using Technic Of Catherization Of Right Auricle or Ventricle, J.Clin. Investigation, 24:106.

COURNAND, A.1950. Some of the Pulmonary Circulation in Normal Man and in Chronic Cardiopulmonary diseases, Circulation, 11:641.

CUNHA, E. de M. S.1931. A evolução da Odontologia no Brasil: Memória histórica. In Atas e Trabalhos do Terceiro Congresso Odontológico Latino Americano, vol.III. Rio de Janeiro, Imp.Nacional.

CUNHA, E.S.1968. História da Odontologia. Arquivo Fluminense de Odontologia. Niterói. V.1, n.4.p.18-24.nov.

DANTES, M. A. M.1980. Institutos de Pesquisa Cientifica no Brasil. In: FERRI, M. G \& MOTOYAMA, S. (Orgs) Historia das Ciências no Brasil. V.2. São Paulo: Edusp/EPU.

DANTES, M. A. M. 1988. Fases da implantação da ciência no Brasil. Quipu, 5:265275.

DÉCOURT, L. V.1945. Lições de Patologia Cardiovascular São Paulo. Melhoramentos,

DEFINE. D. 1937.Fratura do colo do fémur. São Paulo. Rev. Tribunais.

DEFINE. D. 1938. A preluxação do quadril. Arq. Brasileiros Cir. Ortop. n.6.

DEFINE. D. 1940. Novo modelo de mesa para redução das fraturas da coluna. Anais $4^{\mathrm{o}}$ Congresso Brasileiro Ortopedia e Traumaatologia.

DEFINE. D. 1940. Novo processo para estabilizar a articulação tíbio társica no pé paralítico. Anais $4^{\circ}$ Congresso Brasileiro de Ortopedia e Traumatologia.

DEFINE. D.1942. Considerações sobre alguns casos de lesão da fibrocartilagem do joelho, $5^{\circ}$ Congresso Brasileiro Ortopedia e Traumatologia.

DEFINE. D.; FRASCÁ, I.D.1938. Traumatismos obstétricos da região escapulo humeral. Arq. Brasileiros Cirurgiões Ortopédicos.

DEFINE. D.1944. Novas aquisições no terreno do tratamento das osteomielites. Arq. Brasileiros Cir. Ortopédicos.

DOMINGUES, H.M.B. 1995. Ciência, um Caso de Política: as relações entre as ciências naturais e agricultura no Brasil Império. Tese Doutorado, São Paulo: FFCLUSP. 
DUARTE, L. R. 2002. Luiz Romariz Duarte, Engenheiro Mecânico; prof. Titular da Escola de Engenharia São Carlos - USP. Entrevista concedida a Ana Maria Antonio, no Departamento de Bioengenharia da Universidade de São Paulo, no dia 20 de outubro. Bioengenharia no Brasil. 01 fita Cassete.

DUBOS, R. 1960. Pasteur and Moder Science. New York. Anchor Books Doubledey Co.

EDLER, F.C.1992. As Reformas do Ensino Médico e a Profissionalização da Medicina na Corte do Rio de Janeiro: 1854-1884. Dissertação de Mestrado, São Paulo. FFCLUSP.

ENSELME, J.1973. Mort et maladies a raube de I'humanité. Lyon, Camugli.

ENTRALGO, P. L. 1961. La Historia Clinica - Historia y Teorla del Relato Patografico, Barcelona. Ed. Salvat, $2^{\text {a }}$ edição p. 147

EPSTEIN, J.1995. Altered conditions- disease, medicine and storyteller. Nova York, Vintage Books.

EPSTEIN, J.; STRAUB, K. 1991. Body guards: the cultural politics of gender ambiguity. Nova York/Londres, Routledge.

EWBANK, T. 1976.Vida no Brasil. São Paulo: Edusp.

FARIAS SOBRINHO, J. R. 1973. 140 anos do ensino farmacêutico no Brasil: 18321972. João Pessoa: ESLF.

FÁVERO, F. 1975. Medicina Legal, $10^{\circ}$ edição $2^{\circ}$ vol. Belo Horizonte/São Paulo. Itatiaia/Martins.

FERNANDES, T. M. D.1991. A produção da vacina antivariólica no Brasil da monarquia a 1920: a ciência, a técnica e o "poder dos homens", 1991. Dissertação de Mestrado, Rio de Janeiro: Ensp.

FERREIRA, L. O.1996. O Nascimento de uma instituição científica: o período médico brasileiro da primeira metade do século XIX, 1996. Tese de Doutorado, São Paulo: FFLCH-USP.

FERRI, M. G \& MOTOYAMA, S. 1979(orgs.) História das Ciências no Brasil, 3 v. São Paulo: Edusp/EPU.

FIGUEIRÔA, S. F. M.1997. As ciências Geológicas no Brasil: uma historia social e institucional, 1875-1934. São Paulo: Hucitec.

FRAME, J.W. 1980. A convenient animal model for testing bone substitute materials. J. Oral Surgery, 38:176-180.

FONSECA COSTA, A. H. P.da.1970. Aspectos Hemôdinamicos da Circulação Colateral Pulmonar em Pneumopatias Crônicas. Tese de Livre Docência de Fisiologia, Instituto de Ciências Biomédicas, UFRJ - Universidade Federal do Rio de Janeiro. 
FONSECA, M. R. F. da.1995. As conferências populares da Glória: a divulgação do saber científico, Manguinhos - Historia, Ciência, Saúde, 2(3): 135-166.

FORTUNA, A. de A.1968. A Odontologia no Plano Federal. Brasília. Imp. Nacional.

FOUCAULT, M. 1980. O Nascimento da Clinica. Rio de Janeiro: Forense Universitária.

FOUCAULT. M. 1994. The order of things:an archaelogy of the human sciences. Nova York, Vintage Boosks.

FOUCAULT. M. 1977. A história da sexualidade - a vontade do saber. Rio de Janeiro, Graal.

FOUCAULT, M. 1977. O nascimento da clínica. Rio, Florense Universitária.

FOUCAULT. M. 1963. La naissance de la clinique. Paris. PUF.

FRAGOSO, J. L. 1990. Economia brasileira no século XIX. In: Linhares. M.I. (Org). História Geral do Brasil, Rio de Janeiro: Ed. Campus.

FRANK, A. 1995. The wounded storyteller: body, illness and ethics. Chicago.Londres. The University of Chicago Press.

FRASCÁ. I. D.1940. Considerações sobre o pé torto. Estatística do Pavilhão Fernandinho Simonsen. An. 4o. Congr. Brasileiro Ortop. e Traumatologia.

GALVÃO NETO, C. 1990. A profissão odontológica no Brasil. Anal Academia Brasileira de Odontologia, 1989/9027-98.

GARCIA, J. C.; OLIVEIRA J. C. \& MOTOYAMA S. 1980.O desenvolvimento da história da ciência no Brasil. In: Ferri, M. G. \& MOTOYAMA, S. (Orgs.) História das Ciências no Brasil. 2.v. São Paulo: Edusp/EPU.

GAMBETTA, W. 1987.Soldados da saúde: a formação dos serviços de saúde pública de São Paulo (1889-1930). Dissertação de Mestrado. São Paulo: FFLCH-USP.

GINZBURG. C. 1989. Mitos, emblemas e sinais-morfologia e história. São Paulo, Compamnhia das Letras.

GOMES, O.C. 1974. A História da Medicina no Brasil no Século XVI, Cidade do Rio de Janeiro, Estado da Guanabara.

GOMES, J. L. E. 2003. João Luis Ellera Gomes, Médico Ortopedista, prof. Adjunto do departamento de cirurgia da Faculdade de medicina da Universidade Federal do Rio Grande do Sul - UFRGS. Entrevista concedida a Ana Maria Antonio, em sua Clínica na cidade de Porto Alegre. Bioengenharia no Brasil. 02 fitas Cassete. 
GOOT, V. L.; DUTTON, R.C.;YOUG, W. P. 1966. Replacemente of the Canine Mitral Valve With a Graphite Coated Hinged Leaflet Valve. Surge Gynec Onst. 123:43-50.

GUASTALDI, A.C. 1997. Biomateriais - tese apresentada. UNESP - Universidade Estadual Paulista,campus de Araraquara.

GUASTALDI, A. C. 2002. Antonio Carlos Guastaldi, prof. Do Instituto de Química da Universidade Estadual Paulista - UNESP, Entrevista pessoal concedida a Ana Maria Antonio, na cidade de Araraquara no dia 09 de Agosto. Bioengenharia e Biomateriais. 02 fitas cassete.

HAWKINS, A.H.1993. Reconstructing illness - studies in pathohraphy. Indiana, Purdue University Press.

HELLER, A. 1993. Uma teoria da história. Rio de Janeiro, Civilização Brasileira.

HELSINKI I, D. de. 1964. Associação Médica Mundial - 1964- Adotada na $18^{\mathrm{a}}$. Assembléia Médica Mundial, Helsinki, Finlândia.

HELSINKI II, D. de.1975. Associação Médica Mundial - 1964 - 1975. Adotada na $18^{\mathrm{a}}$. Assembléia Médica Mundial, Helsinki, Finlândia (1964). Revista na 29a . Assembléia Mundial de Médicos, Tóquio, Japão.

HELSINKI III, D. de. 1983. Associação Médica Mundial - 1964 - 1983. Associação Médica Mundial - 1964 - 1983. Adotada na 18ª . Assembléia Médica Mundial, Helsinki, Finlândia (1964), alterada na 29a. Assembléia, em Tóquio, Japão (1975) e 35a . Em Veneza, Itália.

HELSINKI IV, D. de.1989. Associação Médica Mundial - 1964 - 1989. Associação Médica Mundial - 1964- 1989. Adotada na $18^{\mathrm{a}}$. Assembléia Médica Mundial, Helsinki, Finlândia (1964), alterada na 29a . Assembléia, em Tóquio, Japão (1975), 35a . Em Veneza, Itália (1983) e 41 a Em Hong Kong.

HELSINKI V, D. de.1989. Associação Médica Mundial - 1964 - 1996. Adotada na 18a Assembléia Médica Mundial, Helsinki, Finlândia (1964), alterada na 29a Assembléia,

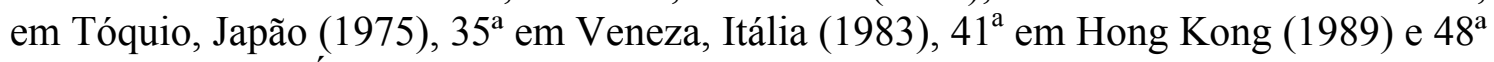
Sommerset West/África do Sul.

HERMETO Jr, S. 1940. A paratireoidectomia na moléstia de Engel-Recklinghausen. Rev. Brasileira Ortopedia e Traumatologia. n.2.

HERMETO Jr, S.1940. Os processos de reabsorção óssea. Significação e consequências cirúrgicas. Rev. Ass. Paulista Medicina. n.16.

HERMETO Jr, S.1940. Forma mono-ostótica da moléstia de Engel-Recklinghausen. Paratireoídectomia. Rev. Brasileira Ortopedia e Traumatologia. n.3.

HERMETO Jr, S.1942. A frequência do adenoma da paratireoíde na moléstia de EngelRecklinghausen. Rev. Cir. São Paulo. n.8. 
HYDÉN, L.C. 1997 “Illness and narrative” Sociology of health \& illness, 19(1):49-64.

IDPC - Instituto Dante Pazzanese de Cardiologia.Revista Comemorativa. Ano 1.n1.

INFANTOSI, A.F.C. 2001. Antonio Fernando Catelli Infantosi, prof. PhD. Universidade Federal do Rio de Janeiro. Entrevista Concedida a Ana Maria Antonio. Criação da Bioengenharia no Brasil. 17 de junho. 02 fitas cassete.

IONESCU, M. I.; PAKRASHI, B.C.; HOLDEN, M.P.;MARY, D.A.; WOLLER, G.H.1972. Results Fron Aortic Valve Replacement With Frame Supported Fascia-Lata and Pericardial Grafts. J.Thorac Cardiovasc Surg, 64:340-53.

ISAKSSON, S.; ALBERIUS, P.; KLINGE, B.; JONSSON, J.; HALLBERG, E.; WENDEL, M.; 1992. Regenerative response to membranous and enchondral Iyophilized allogeneic bone in rabbit skull defects. Scand. J. Plast. Reconstr. Surg. Hand. Surg. 26(2)147-153.

JANY, J.; MORETZSOHN, de. C. J. 1942. Cineradiografia indireta. O método brasileiro de cineradiografia clínica. Rev. Paulista Tisiol. n.8.

JANY, J.; MORETZSOHN, de. C. J. 1943. Cronocinegrafia radiológica. Radiologia Argentina. An. Congr. Buenos Aires.

JANY, J.; MORETZSOHN, de C. J. 1947. Princípios fundamentais de aplicação do cineradiografia indireta como método auxiliar de diagnósticoradiológico. An. J. Roent. Rad. n.57.

JATENE, A.D. 2003. Adib Domingos Jatene, diretor do Hospital do Coração - HCor Hospital do Coração Associação do Sanatório Sírio em São Paulo. Entrevista pessoal concedida no Hcor em São Paulo, Ana Maria Antonio. Em 20 de junho. Desenvolvimentos da Bioengenharia no Brasil

JOBIM, L.C.1984. Os Jardins Botânicos e o fomentismo portugues no Brasil: In.3a Reunião da Sociedade de Pesquisa Histórica. Anais...SP.

KANAN, E. J.1939. Disostose cleido-craneana e coxa-vara congênita. Med. Cir. n.2.

KERMAN, M. C.; NEWMANN, M. M.; LEVOWITZ, B.S.; STUCKLEY, J.H.; DENNIS, C. 1957. A Prosthesis to Replace the Mitral Valve. J. Thorac Cardiov. Surg. 3:698-706.

KLEINMAN, A.1988. The illness narratives - suffering, healing \& the human condition. Nova York. Basic Book.

LARANJA, F.S.; DIAS, E.; NOBREGA, G.; MIRANDA, A; 1956. Chagas Diseases. A. Clinical, epidemiologia and pathologic study, Circulation, 14:1035.

LATOUR, B. 1994. Jamais fomos modernos. Rio de Janeiro, editora 34. 
LE GOFF, J. 1991. "Uma história dramática”. Em As doenças têm história. Lisboa. Terramar.

LEITE, V. da G.1962. Odontologia Legal. Bahia. Era Nova.

LEIVAS, T. P. 2001. Tomaz Puga Leivas, engenheiro Comissão de Projetos do IOT Instituto de Ortopedia do Hospital de Clínicas da Faculdade de Medicina da Universidade de São Paulo. São Paulo. Entrevista pessoal concedida Ana Maria Antonio no IOT - Instituto de Ortopedia, em 20 de junho. Bioengenharia na Ortopedia e no Brasil. 02 fitas Cassete.

LEME, J. T. 2002. José Tadeu Leme, engenheiro proprietário da empresa EngimplanEngenharia de Implante Indústria e Comércio Ltda. Entrevista pessoal concedida a Ana Maria Antonio na cidade de Rio Claro no dia 27 de maio. Empresas que desenvolvem bioengenharia no Brasil. 02 fitas cassete.

LEMOS, F. C.1954. Contribuição à historia do Instituo Bacteriológico: 1892-1940. Revista do Instituto Adolfo Lutz, 14:1-161 (n. especial).

LILlECHEI, C.W. 1994. The Birth of Open-Heart Sugery: Then The Golden Years. Cardiovasc Surg; 2:308-17.

LIMA. L. B.1931. Tratamento cirúrgico da tuberculóse óssea. Recife. Impressora Industrial.

LIMA, A. J. de S. 1901. As sciencias medico-pharmaceuticas, período 1808-1900. In: Associação do Quarto Centenário do Descobrimento do Brasil (Org). Livro do Centenário, 1500-1900, 4v. Rio de Janeiro: Imprensa Nacional.

LOBO, F.B.1964. O Ensino de Medicina no Rio de Janeiro. V 1 Rio de Janeiro. Departamento Imprensa Nacional.

LONG, E. R. 1942. A History of Cardiology. Baltimore, C. C. Thomas. Ed.

LOPES, M. M.1997. O Brasil Descobre a Pesquisa Científica: os museus e as ciências naturais no século XIX. São Paulo: Hucitec.

MAGAlHÃES, A. A. A.1901. O Coração no Béri-Béri Estudo Clínico. Rio de Janeiro, Tip. Leuzinger.

MAGAlHÃES, F. 1932. O Centenário da Faculdade de Medicina do Rio de Janeiro, 1832-1932. Rio de Janeiro: Tip. Barthel.

MARCZYK, L. R. S. 2002. Luiz Roberto S. Marczyk, médico ortopedista, da Clínica de Ortopedia e Fraturas, na cidade de Porto Alegre - RS. Entrevista pessoal concedida Ana Maria Antonio, na cidade de Porto Alegre - Rio Grande do Sul. Bioengenharia na Ortopedia do Brasil. 02 fitas Cassete.

MARGUTTI, R.; BORGES, S.;CAMPOS FILHO, C.M.; GALLUCCI, C.; BRANCO Jr, L.B.1955. Tratamento cirúrgico da estenose valvular aórtica. Revista Paulista Med. 46:82-91. 
MARTINS COSTA, D. A.1889. Tratado das Moléstias do Coração e dos Grossos Vasos Arteriais. Rio. H.Lombaerts e Co.

MC ENAMY, M. T.; ROSS, D. N.; YATES, A.K. 1972. Cusp Degeneration in Flame Mounted Autologous Fascia-Lata Mitral Valves-Thorax. 27:23.

MEIHY, J. C. S. \& BERTOLli FILHO, C. 1990. História Social da Saúde: opinião pública versus poder, a campanha da vacina-1904. São Paulo: CEDHAL Estudos, 5.

MICHAELIS, D.1998. Moderno dicionário da lingua portuguesa. São Paulo. Companhia Melhoramentos.

MIRKOVITCH, U.; AKUTSU, T.; SEIDEL, W.; KOLFF, W.J. 1961. Study of Thrombosis on Plastics Placed Inside the Heart Resulting in a Mitral Valve With Chordae Thendineae. Tr. Am. SC. Art. Int. Or. 7:345-9.

MOACIR, P.1938. A Instrução e o Império. Tomo I. São Paulo: Cia Editora Nacional.

MOREIRA, F. E. G. 1937. Revista da Associação Paaulista de Medicina, vol. XI.n.4.outubro . Pág.201-204.

MOREIRA, F. E. G. 1937. Conferencia pronunciada por ocasião de sua recepção na Academia Nacional de Medicina do Rio de Janeiro, 25 de novembro.

MOREIRA, F. E. G. 1938. Principios fundamentais da paralisia infantil. São Paulo. Empr. Gráf. Rev. Tribunais.

MOREIRA, F. E. G.1939. Seqüelas da paralisia infantil. $3^{\circ}$ Congresso Brasileiro Ortopedia e Traumatologia.

MOREIRA, F. E. G.1939. Indicações dos transplantes ósseos em cirurgia ortopédica. São Paulo. Empr. Graf. Revista Tribunais.

MOREIRA, F. E. G.1939. Contribucion al estudio del sindrome de Volkmann. Rev. Ortop. y Traumatol.

MOREIRA, F. E. G.1940. A Special Stud-Bolt Screw for Fixation of Fractures of the Neck of the Femur. J. Bone and Joint Surg, July.

MOREIRA, F. E. G.1946. Tratamento da pseudoartróse do colo do fêmur pela óteosintese. Rev. Hosp. Clin.n.1.

MOREIRA, F. E. G.; BATALHA, E. de S.C.; CAMARGO, F.P.de. WERTHEIMER, L.G. 1948.Tratamento das fraturas e pseudoartroses do colo do fêmur pela associação de enxertos ósseos esponjoso e corticais. Enxêrto bicondiliano. Rev. Hosp. Clin. n.3.

MOREIRA, F. E. G.; BATALHA, E. de S. C.;CAMARGO, F. P.de. WERTHEIMER, L. G.1949. Fixação da cabeça femural na ósteosíntese do colo do fêmur. Técnica e aparelhagem. Rev. Hosp. Clin. n.4. 
MORRIS, B. D.1998. IIIness and culture in the postmodern age. Bekeley/LosAngeles/Londres. The University of California Press.

MOULIN, A.M. 1991.”Os frutos da ciência”. Em Jacques Le Goff (org). As doenças têm história. Lisboa, Terramar.

MURAD NETO, S. 1984. Evolução e Avanços em Cardiologia no Brasil. J. B. M. 46:70.

NAPOLI, M. M. M.1991. Programas dos cursos de graduação, residência, pósgraduação e de extensão universitária. São Paulo. FMUSP - DOT - IOTHC.

NAPOLI, M. M. M.2001. Manlio Mario Marco Napoli, prof. Emérito da Faculdade de Medicina da Universidade de São Paulo - Ortopedia e Traumatologia - Entrevista pessoal, Ana Maria Antonio, concedida em sua residência em São Paulo, História da Ortopedia no Brasil. 04 fitas cassete.

NOVAIS, F.A.1983. Portugal e Brasil na Crise do Antigo Sistema Colonial. São Paulo: Hucitec.

NUREMBERG, C. de.1947. Norma especifica sobre a ética na pesquisa em seres humanos. 1947.Tribunal Internacional de Nuremberg.

OLIVEIRA, S. M. 2003. Sérgio Mascarenhas de Oliveira. Diretor do IEA - Instituto de Estudos Avançados da Universidade de São Paulo - PIEPAL - Programa Internacional de Estudos e Projetos para a América Latina, na cidade de São Carlos - SP. Entrevista pessoal concedida a Ana Maria Antonio no dia 14 de maio, no IEA - Instituto Estudos Avançados. Início bioengenharia na USP, e no Brasil. 02 fitas Cassete.

OLIVEIRA, O. 1934. Noções Fundamentais de Cardiologia, Rio de Janeiro, Editora Guanabara.

PARDAL, R. 1937. Medicina aborígine americana. Buenos Aires. J. Anesi. Ed. (pref.1937)p.33 e segs.

PARPAIOLLI, J. R. 2002. José Roberto Parpaioli, engenheiro da empresa BAUMER localizada na cidade de Mogi Mirim - SP. Entrevista pessoal concedida Ana Maria Antonio, na BAUMER em 05 de junho. Bioengenharia em empresas no Brasil. 01 fita Cassete.

PAZZANESE, D. 1940. A Fonocardiografia. São Paulo. Prefeitura do Município de São Paulo.

PAZZANESE, D. 1942. Modificações de Forma do Eletrocardiograma. S.Paulo. Prefeitura do Município de S. Paulo.

PEREIRA, J.C. 2003. José Carlos Pereira, Engenheiro Elétrico, prof. Dr. presidente da Interunidades Bioengenharia EESC-FMRP-IQSC. Entrevista pessoal concedida a Ana 
Maria Antonio no dia 22 de agosto, no Depto de Engenharia Elétrica da USP. Bioengenharia no Brasil. 01 fita Cassete.

PORTER, R. 1997."História do corpo". Em Peter Burke(org), A escrita da história. São Paulo, Unesp. Pp.291-326.

PUECH, L. R.1937. O problema da luxação congênita no Brasil. São Paulo. Emp. Gráf. Rev. Tribunais.

PUIG, L. B.; BITTENCOURT, D.; MELLO, R.; PIGOSSI, N.; BELLOTI, G.; SOSA, E,; PILLEGI, F.; ZERBINI, E. J. 1975. Resultados Tardios com Valva Cardiaca de Dura-Mater. Revista Brasileira de Medicina. 32:211.

RAMOS, J.1935. Lições de eletrocardiografia clinica. São Paulo, Editora Nacional

REIS, N. B.; DRUMOND NETO, C.; SOARES, R. V.G.1978.Endocardiopatias Crônicas - In: BENCHIMOL, A.B.; SCHLESINGER, P. (ed) - Enciclopédia Médica Brasileira, vol 2, seçãoV. Rio. Livro Médico.

REVISTA DO INCOR, 1999. Revista Comemorativa do Instituto do Coração do Hospital das Clínicas da Faculdade de Medicina da Universidade de São Paulo e da Fundação E. J. Zerbini.n.3.

REVISTA DO IDPC - Revista Comemorativa do Instituto Dante Pazzanese de Cardiologia. Ano 1 n.1. São Paulo.

REVISTA DO IDPC - Revista Comemorativa do Instituto Dante Pazzanese de Cardiologia - 100 anos. Ano 2 n.6.

RESOLUÇÃO 196/96.1996. - Diretrizes e Normas Regulamentadoras de Pesquisa Envolvendo Seres Humanos. Conselho Nacional de Saúde.

RIGATTO, M. 1973. Fisiopatologia da Circulação Pulmonar. São Paulo. BykProcienx.

ROSEN, G. 1994. Uma História da Saúde Pública. São Paulo: Ed. Unesp/ Hucitec/Abrasco.

RUFFIÉ, J. 1993. La maissance de la médecine préditive. Paris, Éditions Odile Jacob.

SAMICO, A. 1953. Aspectos da história da Odontologia Legal. II Congresso Brasileiro de Historia da Medicina e Ciências Afins. Recife.Pern. Odont. 6(3):8-40.

SAMICO, A. 1992. A profissão odontológica no Brasil: Comentários à legislação vigente. Recife. Pern.

SANTOS FILHO, L.1991. Cadernos de História Geral da Medicina Brasileira. São Paulo; Hucitec Editora Universidade de São Paulo. 
SANTOS FILHO, L. 1980. Pequena História da Medicina Brasileira. Cadernos de Historia. n.13. Editora Parma Ltda. São Paulo.

SARDINHA, J. B.; BOMFIM, R. C. 1948. Tratamento da tuberculose ostéo articular. $8^{\circ}$ Congr. Brasileiro Ortop. e Traumatol.

SCHLESINGER, P.; BENCHIMOL, A.B.; COTRIN, M. 1948 Potenciais Intracavitários do $H$. $V$. D. Arq. Clin. Março.

SCHMITZ, J. P.; HOLLINGER, J. O.1986. The critical size defect as an experimental model for craniomandibulofacial nonunions. Clin. Orthop. Related Research(205):209308.

SCHWARTZMANN, S.1981. A história das ciências no Brasil (1979-1981).

SCHWARTZMANN, S. 1979. Formação da Comunidade Cientifica no Brasil. São Paulo. Companhia Editora Nacional.

SCHWARZ, N.; SCHLAG, G.: THURNHER, M.; ESCHBERGER, J.; DINGES, H. P.; REDI, H. 1991. Fresh atogeneic, frozen allogeneic, and decalcified allogeneic bone grafts in dogs. J. Bone Joint Surg. 73(5):787-790.

SEGADAS, R. 1941. Insuficiência Coronária. Tese Universidade Federal do Rio de Janeiro- UFRJ.

SENNING, A.1967. Fáscia-Lata Replacement of Aortic Valve-J. Thorac Cardiovac Surg. 54:465-70.

SERVELL, M.; ARBONVILLE, G.1964.Valve de Starr e Biblie Metallique. Arch Mal Coeur. 57:147-56.

SEVCENKO, N.1985. A Literatura como missão: tensões sociais e criação cultural na Primeira República. 2.ed. São Paulo: Brasiliense.

SEVCENKO, N. 1983. A Revolta da Vacina: mentes insanas em corpos rebeldes. São Paulo: Brasiliense.

SILVA, A. 1954. A primeira médica do Brasil. Rio de Janeiro: Irmãos Pongetti.

SILVA NETO, O.V. de 2001. Tese apresentada a Universidade Estadual PaulistaFaculdade da Ilha Solteira, mestre em engenharia mecânica. Efeito do recozimento térmico e da taxa de deformidade na microestrutura e precipitação de um aço inoxidável austenitico com alto teor de nitrogênio, utilizado na fabricação de Implantes Ortopédicos. Ilha Solteira.

SILVA, L. F. F. 1892. Adolpho Lutz (1855-1940) In. ANTUNES, J. L. Et al ( orgs) Instituto Adolpho Lutz: 100 anos de Laboratório de Saúde. São Paulo. Ed. 1 Adolpho Lutz/Letras \& Letras. 
SINGER, P. 1968.Desenvolvimento Economico e Evolução Urbana. São Paulo: Cia Ed. Nacional.

SOBRINHO, G. T. 2002. site da internet: http://www/Geovane Tenório SobrinhoCirurgião Dentista.htm. Acesso em: 15 out.

SOUZA, O. P. de. 1939. Estudo sôbre dores lombares. São Paulo. Empr. Gráf. Rev. Trubunais.

SOUZA, O. P. de. 1950. Streptomicina na cirurgia osteo-articular. 9o. Congresso Brasileiro de Ortopedia e Traumatol.

STTAR, A.1960. Total Mitral Valve Replacement: Fixation and Thrombosis. S. Fórum. $11: 258-60$.

STEPAN, N. 1976.Gênese e Evolução da Ciência Brasileira. Osvaldo Cruz e a politica de investigação cientifica e médica. Rio de Janeiro. Ed. Artenova.

TEIXEIRA JUNIOR, A. de S. 1983. Antonio de Souza Teixeira Junior, prof. Doutor, criador da Fundação Brasileira para o Desenvolvimento do Ensino em Ciência FUNBECC. Vice-reitor da Fundação Valeparaibana de Ensino. Entrevista concedida a Ana Maria Antonio, Bioengenharia no Brasil, 02 fitas Cassete.

THEVET, A.1944. Singularidades da França Antártica a que outros chamam de América. Trad. De Estevão Pinto. São Paulo. Companhia Editora Nacional. P.278(Brasiliana, v.229)

TURAZZI, M. I. 1988. A euforia do progresso cientifico e progresso técnico nas transformações urbano-industriais do Rio de Janeiro na virada do século XIX ao XX. In: Congresso Latino-Americano de Historia da Ciência e da Tecnologia. 2. P. 401-9.

TRIBLE, A. S. 1972. First International Roundtable os Fascia-Lata Heart Valves. Surgery. 71:10-14.

TRUJILlO, F. A.1982. Medodologia da pesquisa Cientifica. São Paulo. Mc. GrawHill.

VAZ. P. 1997. O inconsciente artificial. São Paulo. Unimarco.

VESPUCIO, A.1951. El Nuevo Mundo. Cartas relativas a sus viajes y descubrimentos. Buenos Aires; Ed. Nova. P.179-185.

VILHENA, L. dos S. 1921. Recompilação de notícias soteropolitanas e brasílicas, contidas em XX cartas...Imprensa Oficial do Estado da Bahia. p.729.

WEINBERGER. M. 1950. Tratamento das fraturas da diáfise femural. $9^{\circ}$ Congr. Brasileiro Ortop. e Traumatol. 
WERTHEIMER, L. G. 1952. The Sensory Nerves of the Hip Joint. J. Bone and Joint Surr. 34-A:477-487. Apr.

YOUNGER, E. M. \& CHAPMAN, M. W. 1989. Morbidity at bone graft tumor site. J. Orthop. Trauma 3:192-195.

ZANDER. P.1940. Tratamento dos casos inoperaveis de luxação congênita do quadril. Rev. Brasileira Ortop. e Traumatol. n.3.

ZAVAGLIA, C.A.de C. 2002. Cecília Amélia de Carvalho Zavaglia, prof ${ }^{a}$ Titular Departamento de Engenharia de Materiais da Faculdade de Engenharia Mecânica da Universidade Estadual de Campinas. Entrevista pessoal concedida Ana Maria Antonio, na Unicamp. 06 de junho.Biomateriais. 01 fita Cassete.

ZERBINI, E. J.Cirurgia Torácica. In: CORREA NETO, A.1974. Tratado de Cirurgia, vol 3. São Paulo, Sarvier. 
APÊNDICE A 


\section{RELAÇÃO DOS COLABORADORES}

Aos médicos, engenheiros, pesquisadores e proprietários de empresas que através de seus relatos à minha pessoa, juntos colaboram para se constituir a Historia da Bioengenharia no Brasil, Século XX: Estado da Arte. A descrição pessoal de cada pesquisador sobre a Bioengenharia, colaborou para que pudessemos realizar este trabalho, pois esses relatos só foram possiveis devido ao fato da colaboração dos que viveram e registraram em suas memórias toda essa historia do inicio, desenvolvimento e da aplicação bioengenharia no Brasil.

Adib Domingos Jatene

Nascido: 04 de junho 1929

Cidade: Xapuri - Acre.

Médico Cirurgião cardiovascular, professor, pesquisador, Diretor do Hospital do Coração, de São Paulo. Ministro da Saúde.

Antonio Carlos Guastaldi

Cidade: São Carlos - SP

Prof. Dr. do Instituto de Química da Universidade Estadual Paulista - UNESP Araraquara, Grupo de Biomateriais.

Antonio Fernando Catelli Infantosi

Nascido: 01 de setembro de 1947

Cidade: São Paulo - SP

Ph.D., 1986 (Imperial College Londres) Engenharia Elétrica; Mestrado em Engenharia Biomédica; Graduação Engenharia Eletrônica; do Programa de Engenharia Biomédica da Universidade Federal do Rio de Janeiro - COPPE/UFRJ.

Antonio de Souza Teixeira Junior

Professor; Pesquisador; Doutor; criador da FUNBEC. Vice-reitor-Fundação Valeparaibana de Ensino.

Aron José Pazin de Andrade

Nascido: 19 de abril 1961

Cidade: São Paulo-Capital

Piloto Privado Aeronautico; Técnico Metalurgico; Engenheiro Mecânico; Administrador de Empresas; Mestre em Engenharia Mecânica - BioengenhariaUNICAMP; Doutor em Engenharia Mecânica-Bioengenharia-UNICAMP/Baylor College of Medicine; Pós-Doutorado em Engenharia Mecânica-UFMG; Pesquisador Instituto Dante Pazzanene de Cardiologia 
Cecilia Amélia de Carvalho Zavaglia

Nascido: 01 de abril de 1954

Cidade: São Carlos - SP

Professora titular do Depto de Engenharia de Materiais - Faculdade de Engenharia Mecânica da Universidade de Campinas - UNICAMP.

Clóvis Isberto Biscegli

Nascido: 03 de julho 1947

Cidade: São Carlos - SP

Físico da Empresa Brasileira de Pesquisa Agropecuária - EMBRAPA -Centro Nacional de Pesquisa e Desenvolvimento de Instrumentação Agropecuária.

Gloria Dulce de Almeida Soares

Nascido: 14 de outubro 1950

Cidade: Rio de Janeiro - RJ

Engenheira Metalúrgica, Dra em Eng. Metalúrgica e de Materiais - COPPE/UFRJ. Prof. Adj na Escola Politécnica e na COPPE/UFRJ - Instituto do Milenio em Bioengenharia Tecidual e da Rede de Nanotecnologia Molecular e de Interfaces-UFRJ - Metalmat.

João Luis Ellera Gomes

Médico; Pesquisador; Professor Adjunto do Departamento de Cirurgia da Faculdade de Medicina da Universidade Federal do Rio Grande do Sul.

José Carlos Pereira

Nascido: 19 de março de 1953

Cidade: São Caetano do Sul - SP

Engenheiro Elétrico, mestrado Engenharia Elétrica, Dr. Engenharia Eletrônica Inglaterra- University of Sowthmpton. Presisdente do Programa Interunidades Bioengenharia - PPGB-USP. EESC/FMRP/IQSC.

José Batista Portugal Paulin

Nascido: 05 de maio 1934

Cidade: Ribeirão Preto - SP

Professor, Doutor do Departamento de Biomêcanica, Medicina e Reabilitação do Aparelho Locomotor, Responsável pelo Laboratório de Bioengenharia da FMRP.

José Francisco Biscegli

Nascido: 18 de Março 1949

Cidade: São Carlos - SP

Técnico Mecânico; Engenheiro Mecânico FEI; Engenheiro Industrial de Produção Faculdade de Engenharia Industrial; Mestre em Engenharia-Materiais e ProcessosBioengenharia-UNICAMP; Doutor em Engenharia Mecânica-UNICAMP; Diretor do 
Centro Técnico de Pesquisas e Experimentos do Instituto Dante Pazzanese de Cardiologia; Diretor da Divisão de Bioengenharia da Fundação Adib Jatene.

José Tadeu Leme

Nascido: 30 de outubro 1955

Cidade: Rio Claro - SP

Engenheiro Mecânico; proprietário da empresa Engimplan-Engenharia de Implante Industria e Comércio Ltda. Rio Claro - SP.

José Roberto Parpaioli

Químico - Gerente de Pesquisa do Departamento de Tecnologia Baumer SA

Mogi Mirim - SP

Luiz Roberto Stigler Marczyk

Nascido: 07 de dezembro 1945

Cidade: Alegrete - RS

Médico; Pesquisador; Professor Titular de Ortopedia e Traumatologia da Faculdade de Medicina da Universidade Federal do Rio Grande do Sul - UFRGS.

Luiz Romariz Duarte

Nascido: 15 de dezembro 1931

Cidade: Rio de Janeiro - RJ

Engenheiro mecânico; Profesor Titular Escola de Engenharia São Carlos - EESCUniversidade de São Paulo - USP.

Manlio Mario Marco Napoli

Nascido: 10 de dezembro de 1921

Cidade: São Paulo - SP

Médico; Professor Emérito da Faculdade de Medicina FMUSP - Universidade São Paulo.

Ortopedia e Traumatologia

Manoel Amaral Baumer

Nascido: 05 de março 1928

Cidade: Jardinópolis-SP

Presidente do Conselho da empresa Baumer S/A - Mogi Mirim - SP

Maria Adélia Collier Farias

Fundadora Engenharia Biomédica na Faculdade de Engenharia Elétrica e de Computação da UNICAMP. 
Marinalva de Magalhães Pereira

Nascido: 09 de junho 1960

Cidade: Guanhaes - MG

Ph.D em Materiais Ciencia e Engenharia - Prof ${ }^{a}$ do Depto de Engenharia Metalurgica e de Materiais da Universidade Federal de Minas Gerais - UFMG- Grupo de Pesquisa Desenvolvimento de Biomaterais.

Marcos Tadeu Tavares Pacheco

Ph.D. Engenheiro Eletrônico pelo Instituto Tecnológico de Aeronáutica; Mestre em Ciências -Departamento de Física do ITA; Pesquisador - Diretor do IP\&D - Instituto de Pesquisa e Desenvolvimento da UNIVAP.

Sérgio Mascarenhas Oliveira

Nascido: 02 de maio 1928

Cidade: Rio de Janeiro - RJ

Bacharel em Química: UB - Universidade do Brasil; Bacharel em Física: URJ Universidade do Rio de Janeiro; Livre Docente (Dout.) USP - Universidade de São Paulo; Catedrático da USP - Universidade de São Paulo, por concurso; Coordenador do IEASC - Instituto de Estudos Avançados de São Carlos; Diretor do PIEPAL Programa Internacional de Estudos e Projetos para a América Latina

Tomaz Puga Leivas

Nascido: 18 de março 1962

Cidade: São Paulo - SP

Engenheiro - Chefe do Laboratório de Biomecânica LIM-41

Coordenador da Comissão de Projetos do Conselho Diretor do Instituto de

Ortopedia e Traumatologia do Hospital das Clinicas da FMUSP.

Wang Binseng

Mestrado Engenharia Elétrica, com uma tese em engenharia biomédica; Doutor em Ciências em engenharia bio-elétrica no Massachusetts Institute os Technology, tendo realizado uma tese em eletrofisiologia do sistema auditivo; Criador do Departamento de Engenharia Biomédica da Faculdade de Engenharia Elétrica fundou o Centro de Engenharia Biomédica da UNICAMP. 